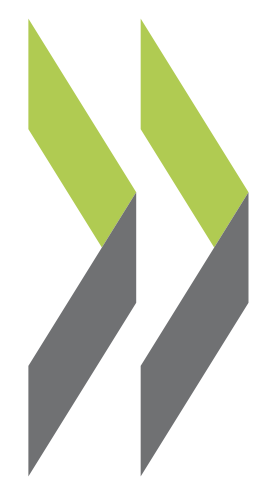

OECD Social, Employment and Migration Working Papers No. 244

The changing labour market for graduates from mediumlevel vocational education and training

\section{Marieke Vandeweyer,} Annelore Verhagen 
DIRECTORATE FOR EMPLOYMENT, LABOUR AND SOCIAL AFFAIRS

EMPLOYMENT, LABOUR AND SOCIAL AFFAIRS COMMITTEE

The changing labour market for graduates from medium-level vocational education and training

July 2020

JEL Codes: J21, J24, J62, I26

Authorised for publication by Stefano Scarpetta, Director, Directorate for Employment, Labour and Social Affairs.

Author: Marieke Vandeweyer, Annelore Verhagen. Contact: marieke.vandeweyer@oecd.org.

JT03463765 


\section{OECD Social, Employment and Migration Working Papers}

\section{www.oecd.org/els/workingpapers}

OECD Working Papers should not be reported as representing the official views of the OECD or of its member countries. The opinions expressed and arguments employed are those of the author(s).

Working Papers describe preliminary results or research in progress by the author(s) and are published to stimulate discussion on a broad range of issues on which the OECD works. Comments on Working Papers are welcomed, and may be sent to els.contact@oecd.org.

This series is designed to make available to a wider readership selected labour market, social policy and migration studies prepared for use within the OECD. Authorship is usually collective, but principal writers are named. The papers are generally available only in their original language - English or French - with a summary in the other.

This document and any map included herein are without prejudice to the status of or sovereignty over any territory, to the delimitation of international frontiers and boundaries and to the name of any territory, city or area.

\footnotetext{
Note by Turkey:

The information in this document with reference to "Cyprus" relates to the southern part of the Island. There is no single authority representing both Turkish and Greek Cypriot people on the Island. Turkey recognises the Turkish Republic of Northern Cyprus (TRNC). Until a lasting and equitable solution is found within the context of the United Nations, Turkey shall preserve its position concerning the "Cyprus issue".
}

Note by all the European Union Member States of the OECD and the European Union:

The Republic of Cyprus is recognised by all members of the United Nations with the exception of Turkey. The information in this document relates to the area under the effective control of the Government of the Republic of Cyprus.

The statistical data for Israel are supplied by and under the responsibility of the relevant Israeli authorities. The use of such data by the OECD is without prejudice to the status of the Golan Heights, East Jerusalem and Israeli settlements in the West Bank under the terms of international law.

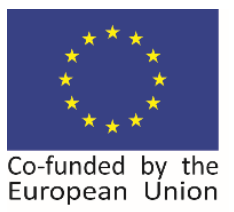

(C) OECD 2020

You can copy, download or print OECD content for your own use, and you can include excerpts from OECD publications, databases and multimedia products in your own documents, presentations, blogs, websites and teaching materials, provided that suitable acknowledgment of OECD as source and copyright owner is given. All requests for commercial use and translation rights should be submitted to rights@oecd.org. 


\section{Acknowledgement}

This report was prepared by the skills team in the OECD Directorate for Employment, Labour and Social Affairs, with the financial assistance of the European Union. The opinions expressed and arguments employed herein do not necessarily reflect the official views of the OECD member countries or the European Union.

The authors are grateful for comments received from Mantas Sekmokas (European Commission DG Employment, Social Affairs \& Inclusion), Antonio Ranieri (European Centre for the Development of Vocational Training, Cedefop), Mark Pearson (OECD Directorate for Employment, Labour and Social Affairs), Viktoria Kís (OECD Centre for Skills), Anthony Mann (OECD Directorate for Education and Skills) and Marco Paccagnella (OECD Directorate for Education and Skills). 


\section{Table of Contents}

OECD Social, Employment and Migration Working Papers ...................................................................2 2

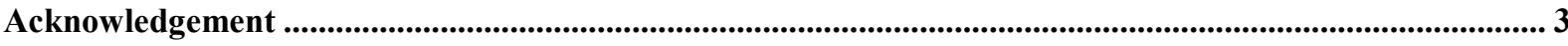

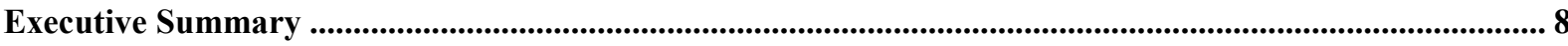

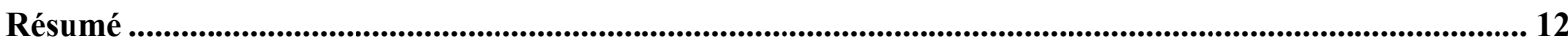

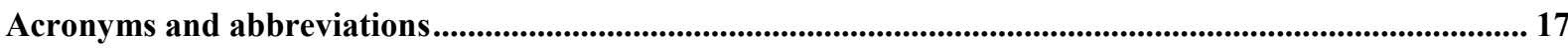

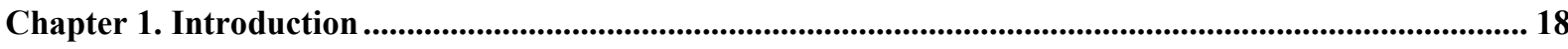

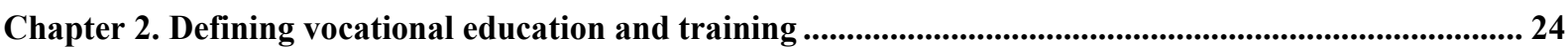

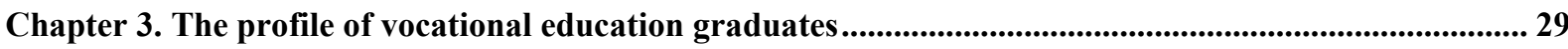

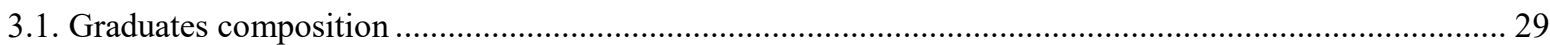

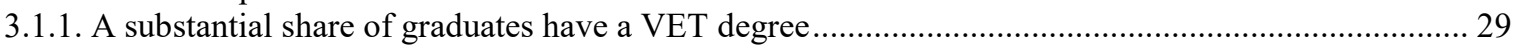

3.1.2. Technical subjects are most popular among VET graduates .................................................... 32

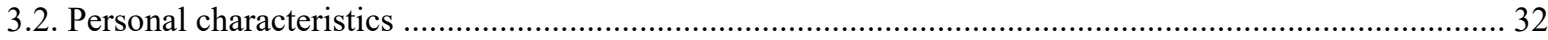

3.2.1. Women are less likely to have a VET qualification .......................................................... 32

3.2.2. VET graduates have lower proficiency in cognitive skills than general education graduates on

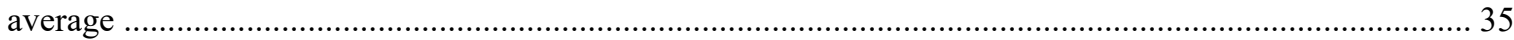

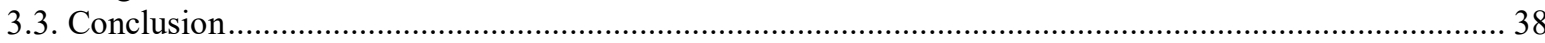

Chapter 4. Labour market outcomes of vocational education graduates................................................40

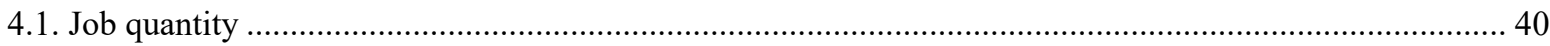

4.1.1. VET graduates have higher employment rates than graduates from general education .................... 40

4.1.2. VET graduates are more often not in employment, education or training than graduates from

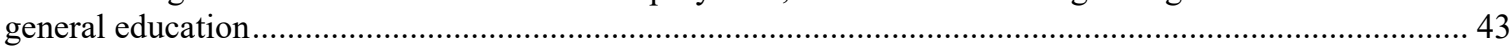

4.1.3. VET graduates have higher work intensity than general education graduates .............................. 45

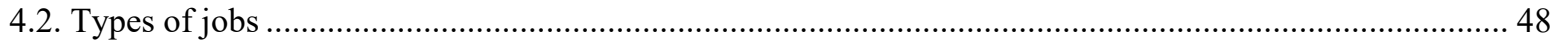

4.2.1. VET graduates are predominantly employed in services and sales jobs, as well as craft

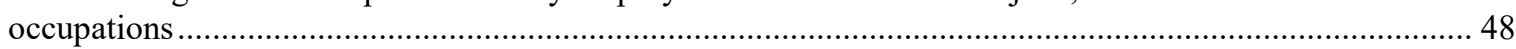

4.2.2. A significant share of jobs held by VET graduates are at risk of change due to automation ............. 52

4.2.3. Most VET graduates work in occupations that match their education level................................... 54

4.2.4. A large share of VET graduates work in small enterprises...................................................... 58

4.2.5. The incidence of self-employment is similar across education groups............................................ 59

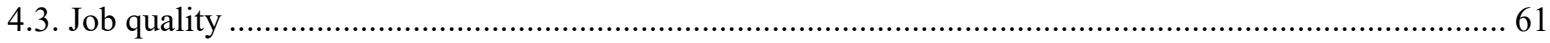

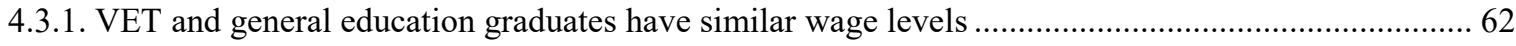

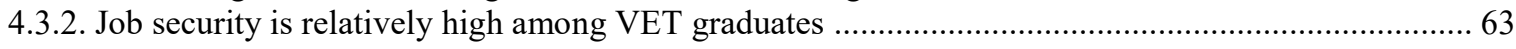

4.3.3. VET graduates are more likely to work in physically demanding jobs than general education

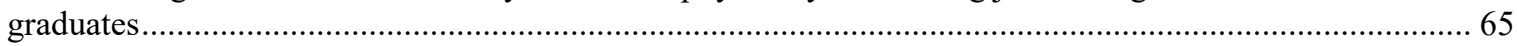

4.3.4. Recent VET and general education graduates are equally likely to have supervisory

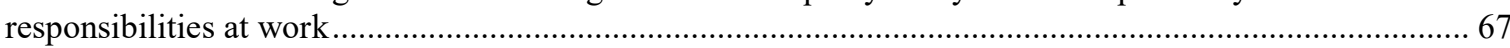

4.3.5. VET and general education graduates have similar exposure to high performance work practices .... 68

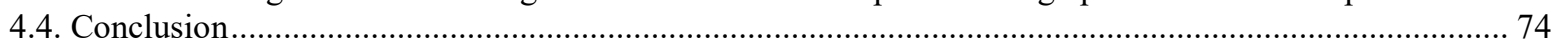

Chapter 5. Has the labour market for vocational education graduates changed? ........................................ 76

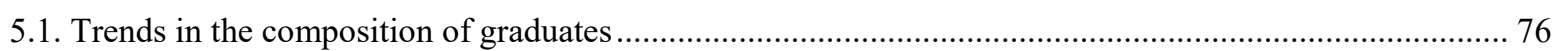

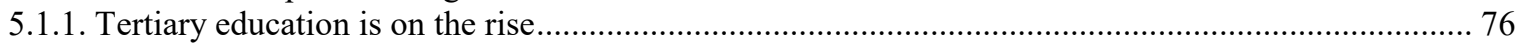

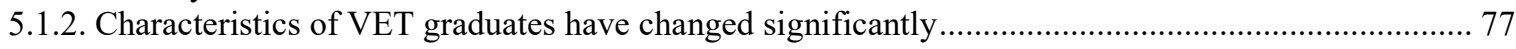

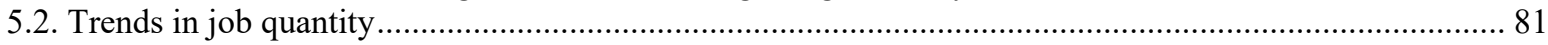

5.2.1. The financial crisis decreased VET graduates' employment rates, but did not raise inactivity .......... 81 


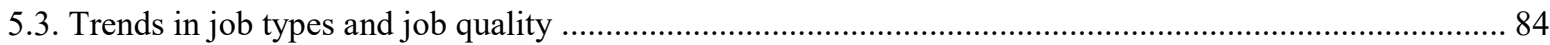

5.3.1. The occupational composition of VET graduates' employment has undergone substantial changes .. 84

5.3.2. The quality of jobs held by vocational and general education graduates has remained similar ..........90

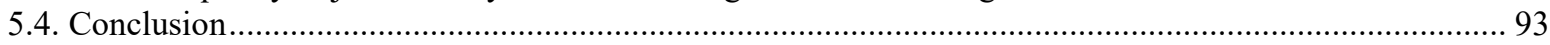

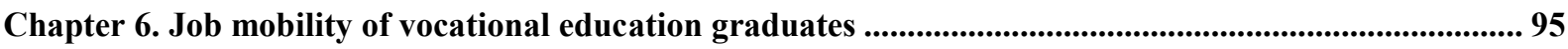

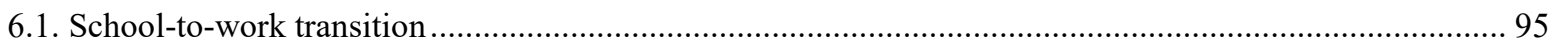

6.1.1. VET graduates transition more quickly into work after graduation than general education

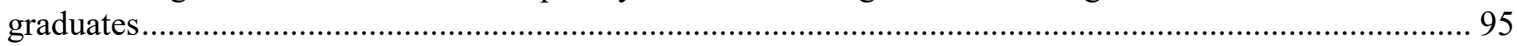

6.1.2. VET graduates' first job is often a good match with their education ......................................... 97

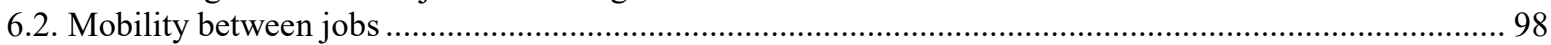

6.2.1. VET and general education graduates are equally likely to change jobs ..................................... 98

6.2.2. VET graduates are less likely than general education graduates to move into better-quality

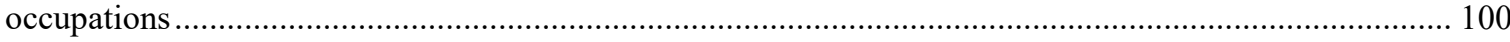

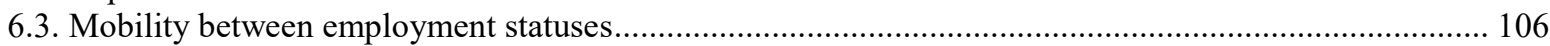

6.3.1. Unemployment spells between jobs are as common among VET graduates as among general

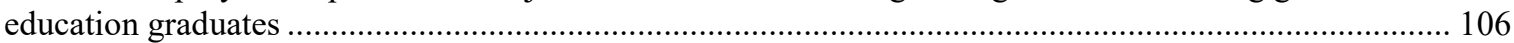

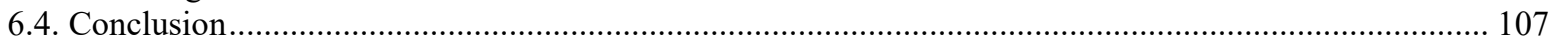

Chapter 7. Labour market outlook for vocational education graduates ................................................. 109

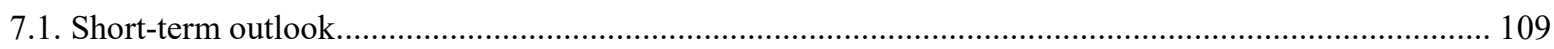

7.1.1. Many occupations that are important for VET graduates are facing surpluses ............................ 109

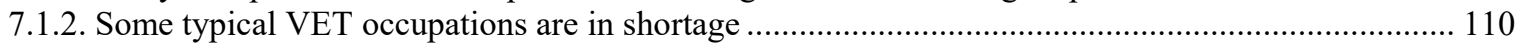

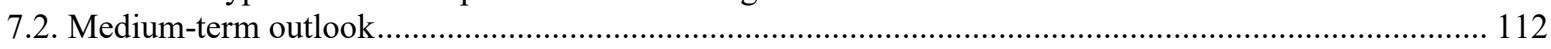

7.2.1. The number of crafts and related trades jobs is projected to decline .......................................... 112

7.2.2. Many of the tasks carried out by VET graduates are at risk of change because of automation ......... 114

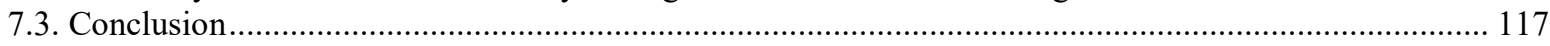

Chapter 8. Policy directions for future-ready vocational education and training ........................................ 120

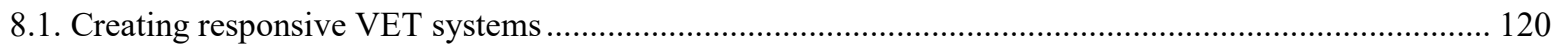

8.1.1. Strong coordination between VET systems and social partners is crucial .................................. 120

8.1.2. Further expansion of and easy access to higher (vocationally oriented) education needs to be

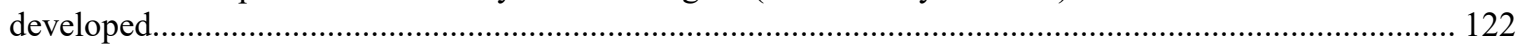

8.1.3. VET systems should broaden their scope to non-traditional fields that are facing strong demand in

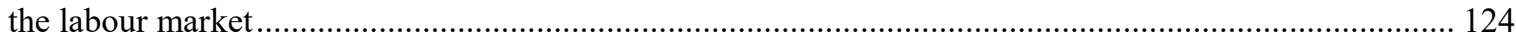

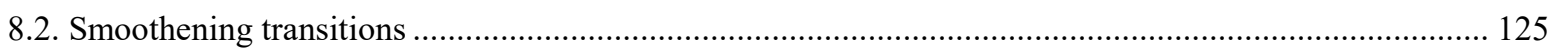

8.2.1. VET students need to leave the education system with solid foundational skills ......................... 125

8.2.2. VET graduates need access to up- and re-skilling opportunities that are responsive to labour

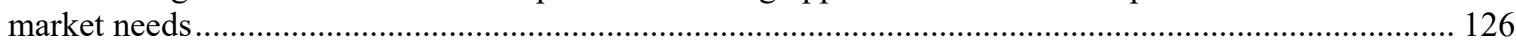

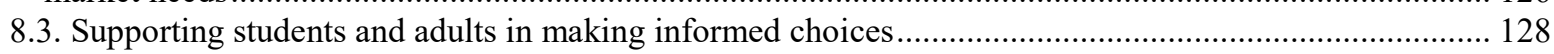

8.3.1. Students need access to high-quality career guidance at early stages...................................... 128

8.3.2. VET graduates need effective career guidance throughout their working lives ........................... 130

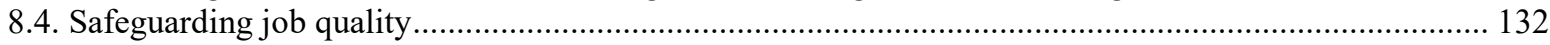

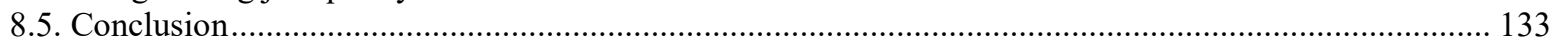

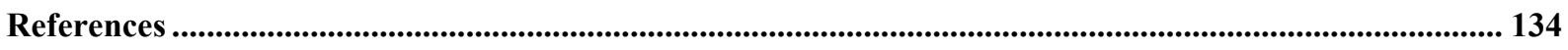

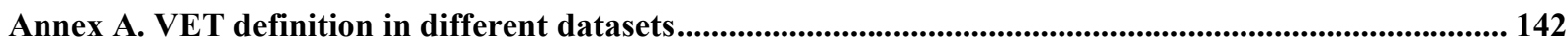

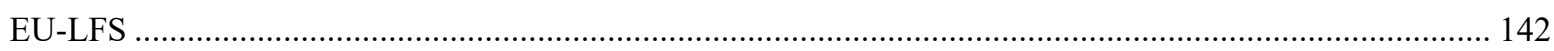

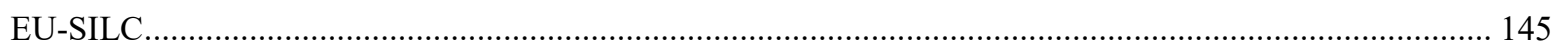

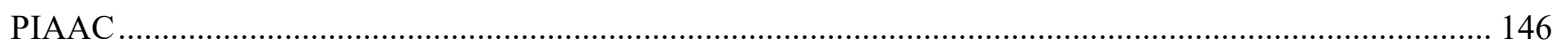

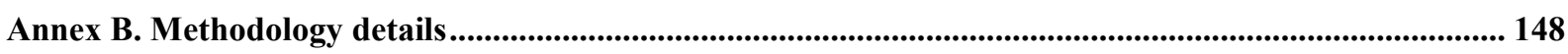

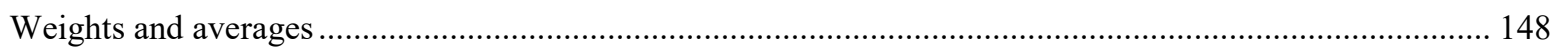

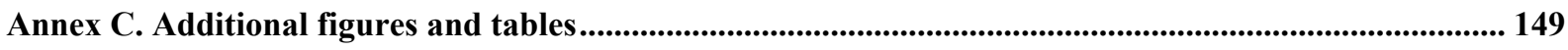




\section{Tables}

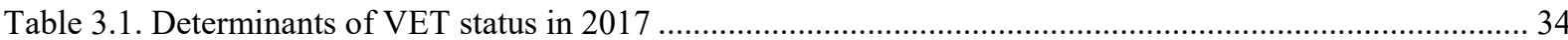

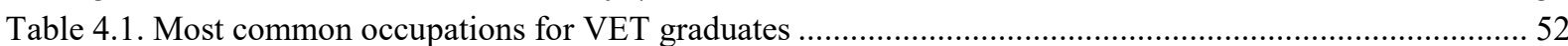

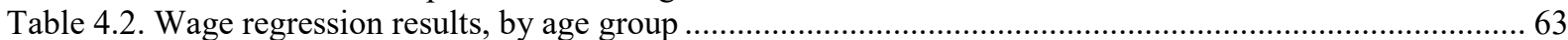

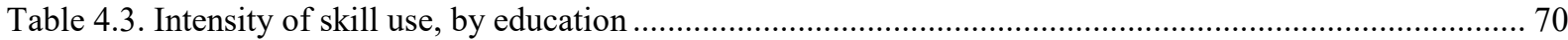

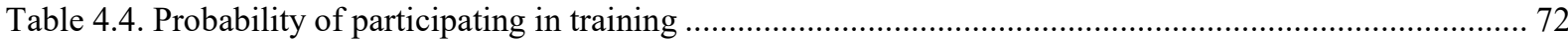

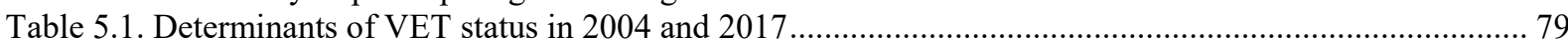

Table 6.1. Probability of making a positive occupation change ............................................................. 105

\section{Figures}

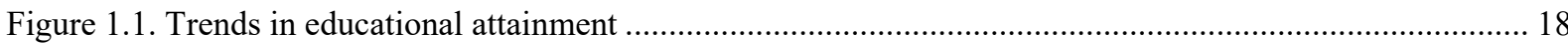

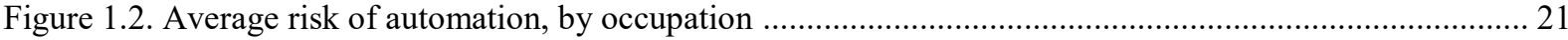

Figure 3.1. T Main activity and reasons for not continuing education, by education....................................... 30

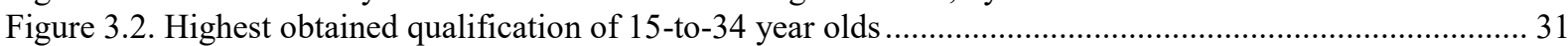

Figure 3.3. Type of work experience during highest level of education ................................................. 31

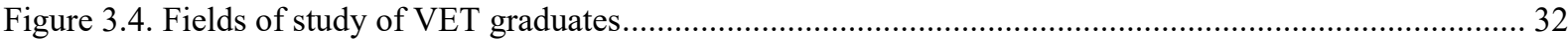

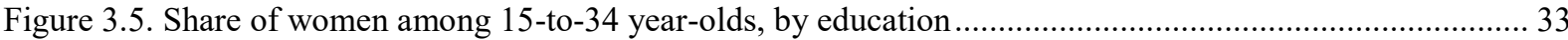

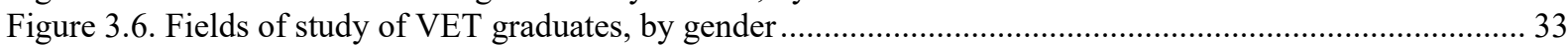

Figure 3.7. Literacy, numeracy and problem-solving proficiency of graduates, by education.......................... 36

Figure 3.8. Percentage of low performers in mathematics, by programme orientation ................................... 37

Figure 3.9. Share of graduates with low literacy, numeracy or problem-solving proficiency, by education ........ 39

Figure 4.1. Share of individuals currently in (un)employment, by education ................................................ 41

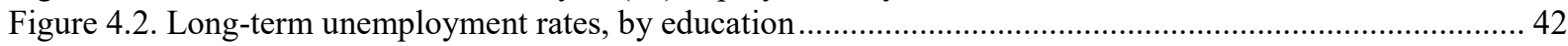

Figure 4.3. Employment and unemployment rates, by age and education ............................................... 43

Figure 4.4. Individuals not in employment, education or training (NEETs), by education ............................. 44

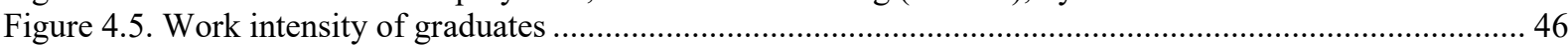

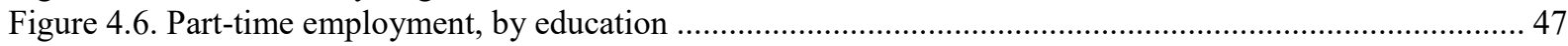

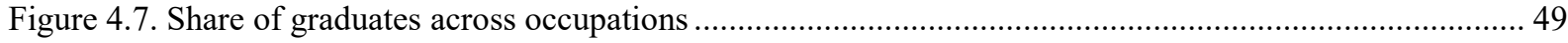

Figure 4.8. Occupational composition of adults with VET qualifications ........................................................ 50

Figure 4.9. Share of VET graduates in occupations, by field-of-study ..................................................... 51

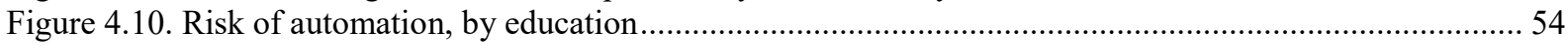

Figure 4.11. The extent to which graduates think their education helps them in meeting the demands of their

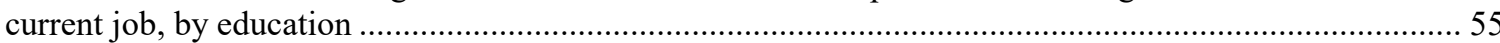

Figure 4.12. Match between the level and field of the highest obtained qualification and current employment, by education.

Figure 4.13. Share of graduates mismatched by field of study, by education and field ................................. 57

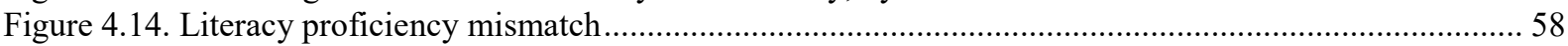

Figure 4.15. Distribution of graduates by firm size, PIAAC average ......................................................... 59

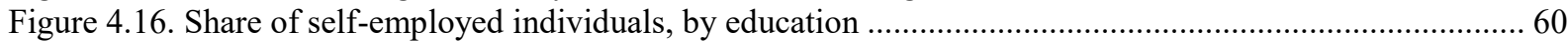

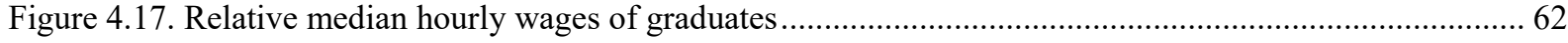

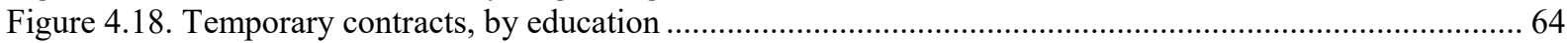

Figure 4.19. Workers' probability of holding a temporary contract, by years since graduation ..........................65

Figure 4.20. Share of individuals who work more than 50 hours per week, by education ...............................66

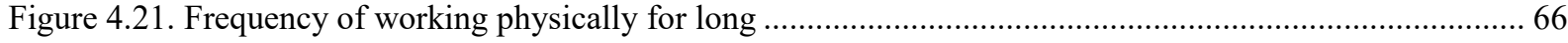

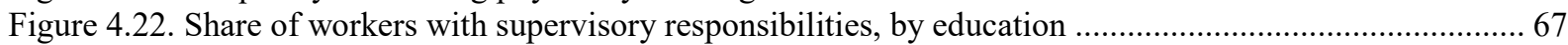

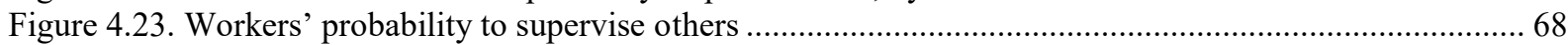

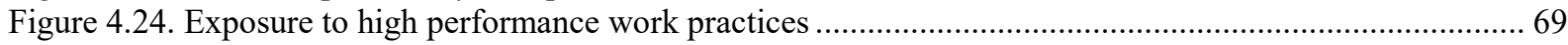

Figure 4.25. Participation in adult learning, by education ................................................................... 71

Figure 4.26. Barriers to participation in formal and non-formal training, PIAAC average ................................ 73

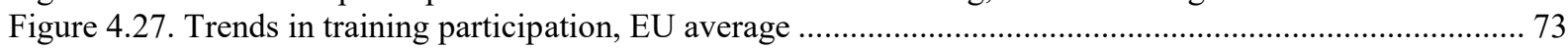




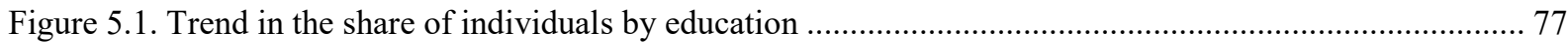

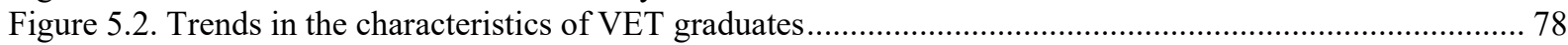

Figure 5.3. Skill composition of graduates, by cohorts with different years since graduation ........................... 81

Figure 5.4. Trends in the share of employed individuals, by education ...................................................... 82

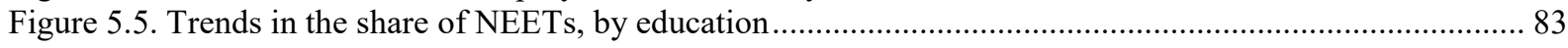

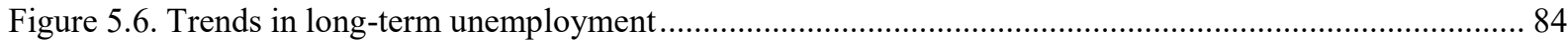

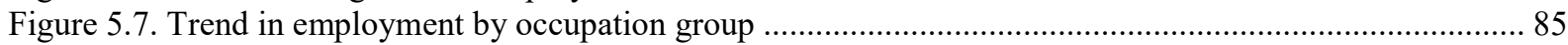

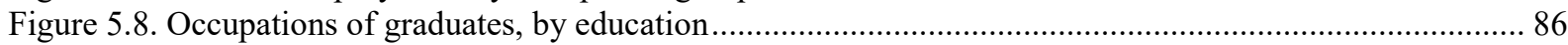

Figure 5.9. Change in the share of VET graduates employed in selected occupation groups ........................... 87

Figure 5.10. Share of VET graduates within each occupation ............................................................... 88

Figure 5.11. Decomposition of the change in occupations where VET graduates find employment (EUaverage)

Figure 5.12. Trend in the share of graduates who have below-median monthly (take home) pay from their main job

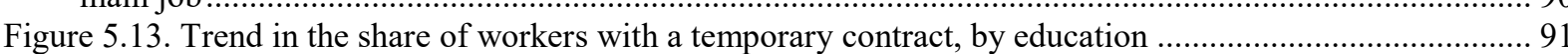

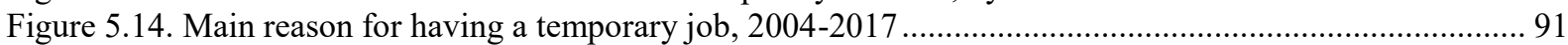

Figure 5.15. Trend in the share of graduates that work more than 50 hours per week .................................. 92

Figure 5.16. Trend in the share of graduates who are supervising others in their job .................................. 93

Figure 6.1. Average time between leaving education and starting first significant job (2004-2009) ................. 96

Figure 6.2. Labour market status one month after graduation (EU average, 2013-2016) ................................. 97

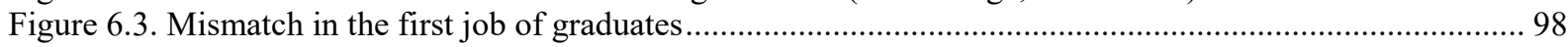

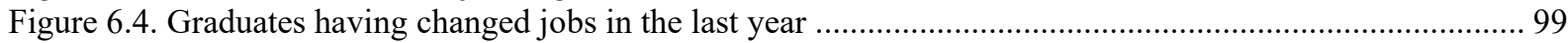

Figure 6.5. Trends in looking for another job, by education .................................................................. 100

Figure 6.6. Share of graduates changing occupations ............................................................................ 101

Figure 6.7. Change in the risk of automation when changing occupations ............................................... 102

Figure 6.8. Change in the average numeracy skill level when changing occupations .................................... 103

Figure 6.9. Change in the median occupation wage when changing occupations ........................................... 104

Figure 6.10. Number of unemployment spells in a four-year period.................................................... 106

Figure 6.11. Duration of non-employment spells of unemployed graduates, by education ............................ 107

Figure 7.1. Skills imbalances and VET employment by occupation ..................................................... 110

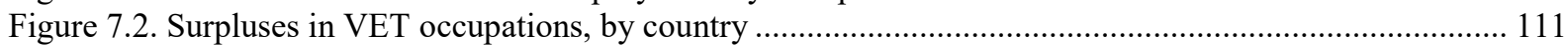

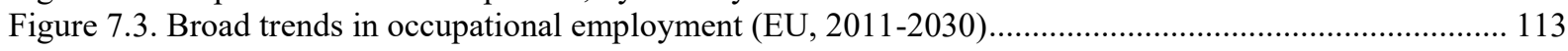

Figure 7.4. Job openings by broad occupation group, 2016-2030 ....................................................... 114

Figure 7.5. Decomposition of difference in automation risk between VET and other graduates ..................... 116

Figure 7.6. Frequency of carrying out bottleneck tasks, by education ......................................................... 119

\section{Boxes}

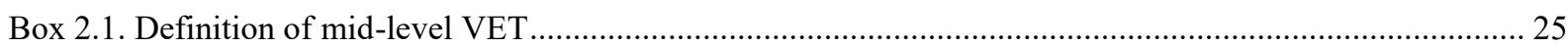

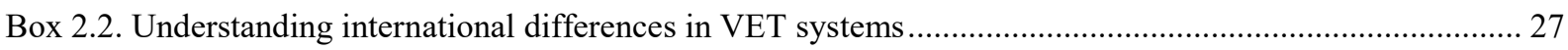

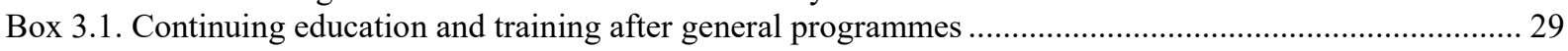

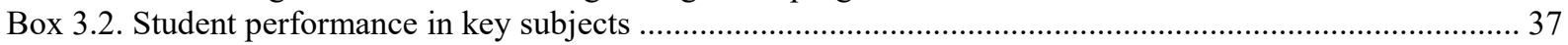

Box 4.1. Comparing graduates' employment rates to older age groups .................................................... 42

Box 4.2. Comparing occupations of different age groups of adults with VET qualifications ............................50

Box 4.3. Measuring mismatches between education or skills and current occupation..................................... 57

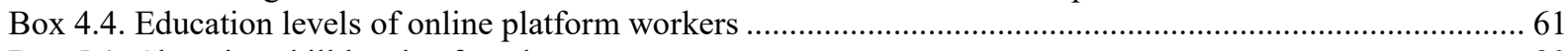

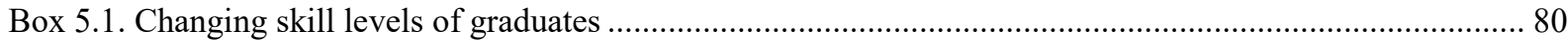

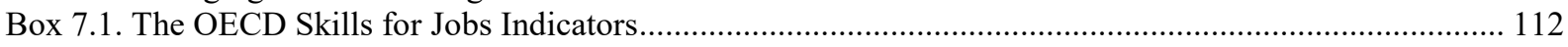

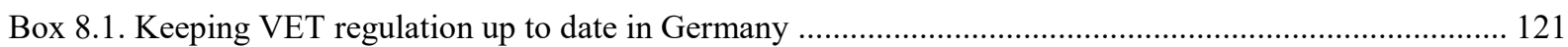

Box 8.2. Facilitating access to higher education through bridging courses................................................. 123

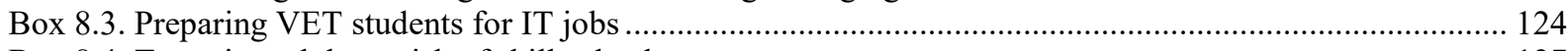

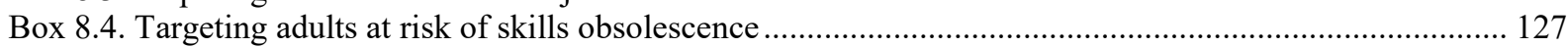

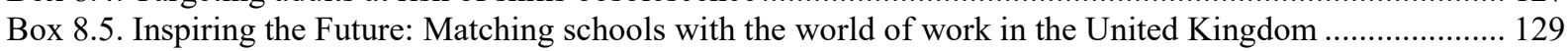

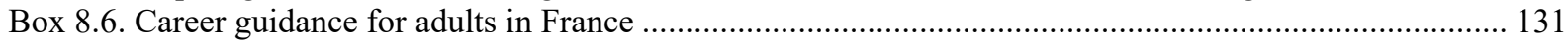




\section{Executive Summary}

Under the impulse of global mega-trends, such as technological progress and globalisation, labour markets in OECD countries have undergone structural changes in recent decades. This has meant that the demand for skills has changed substantially. Moreover, many jobs, particularly those with middle and low skill requirements, are at risk of automation in the next decades.

The process of automation has raised concerns around the labour market outcomes of graduates from vocational education and training (VET), as these graduates have traditionally mainly been employed in middle-wage jobs. Earlier research has shown that VET helps reduce high school dropout, especially for high-risk students, and facilitates school-to-work transitions. In order to maintain and further strengthen the positive impact VET can have on student outcomes in a changing world of work, certain aspects of VET systems might need to be re-engineered, especially in countries with weaker VET systems. This report uses a range of data sources for European countries to analyse the type and quality of jobs held by young adults (aged 15 to 34, referred to as graduates) who have at most an upper secondary or post-secondary non-tertiary degree that is vocationally-oriented, and how this has changed over time. The labour market outcomes of these mid-level VET graduates (referred to as 'VET graduates' throughout the report) are compared to those of graduates with the same level of education but a general orientation, as well as to those with a tertiary education degree (irrespective of its orientation) and those without an upper-secondary education degree. The focus of this report is on these mid-level VET graduates, and therefore does not look at VET organised at higher or lower levels of education, nor at non-formal vocationally-oriented training. Key findings include:

- VET plays a prominent role in education and training systems in EU countries. On average, one out of three individuals aged 15 to 34 hold a mid-level VET degree (defined as upper or post-secondary non-tertiary education with vocational orientation throughout this report) as their highest qualification. However, large difference exist between countries in the importance of VET in the education and training system, with mid-level VET playing a very prominent role in countries like Austria, Germany, the Czech Republic and the Slovak Republic, and only a limited role in countries like Ireland, Cyprus or Malta. The share of young adults with at most a mid-level VET degree decreased slightly on average in the last fifteen years. Countries also differ in the way they organise VET, with some countries having an important workplace learning component in their VET curricula (e.g. Germany, Austria, Switzerland and Norway) and others taking a predominantly school-based approach (e.g. Slovenia, Finland, Portugal). The way in which VET is organised and delivered has an impact on its quality, which in turn influences the attractiveness of VET and the labour market outcomes of graduates.

- Graduates from VET have higher employment rates and lower unemployment rates than graduates from general programmes at the same education level. This is particularly the case in Austria, Germany, Norway, Sweden and Switzerland where 
the labour market outcomes of VET graduates are substantially better than those of general education graduates. Work intensity among VET graduates is also slightly higher than among general education graduates. The performance of VET graduates in terms of job quantity relative to general education graduates stayed relatively stable in the last fifteen years.

- In most job quality dimensions, VET graduates have broadly the same outcomes as general education graduates. VET graduates have moderately higher wage levels than general education graduates on average, and this wage gap is particularly outspoken in countries like Norway, Denmark and Iceland. On the other side, the wages of VET graduates are substantially lower than those of tertiary education graduates, even when they work in similar jobs. VET graduates are less likely than general education graduates to work in temporary jobs in the first years after graduation, although this difference in access to permanent jobs disappears when looking at graduates who left education more than ten years ago. With respect to the quality of the work environment, VET graduates more frequently carry out physically demanding tasks than general education graduates. At the same time, both groups are equally likely to be exposed to high-performance work practices and to have supervisory responsibilities.

- Just over a quarter of VET graduates were employed as service and sales workers in 2017, and an additional quarter as crafts and related trades workers. Around $18 \%$ of VET graduates are employed in high-skill occupations, compared to $26 \%$ of general education graduates. However, the share of young VET graduates in high-skill occupations amounts to more than one third in Germany, Switzerland and Malta. VET graduates are less likely than general education graduates to report being ill-prepared for their job and are more likely to work in occupations that match their education level. Almost one out of four VET graduates work in occupations that do not match their field of study, which is similar as for tertiary education graduates.

- The occupational composition of VET graduates' employment has undergone substantial changes in the past fifteen years. Firstly, VET graduates today are more likely to be working as service and sales workers compared to fifteen years ago. The rise in the importance of these jobs for VET graduates can be explained by a growing importance of sales and services jobs in the overall labour market, as well as VET graduates making up a larger proportion of workers in those occupations. This rising importance of sales and services jobs is accompanied by an increasing share of VET graduates who specialised in services and health and welfare fields. Secondly, despite a significant overall decline in employment in craft and related trades jobs, the importance of that occupation for VET graduates, expressed as the share of total VET graduates working in this occupation, has remained stable. Hence, the job opportunities that remain in this occupation, are increasingly being filled by VET graduates, highlighting the comparative advantage VET graduates hold in this area. Finally, in spite of significant growth of overall employment in high-skill occupations, the share of VET graduates employed in high-skill jobs has gone down slightly on average across countries. However, there are substantial differences between countries. In Germany and Switzerland, for example, the (already relatively large) share of VET graduates working as associate professionals and technicians increased in the past fifteen years. 
- As the labour market for VET graduates is undergoing substantial changes, it could be expected that these graduates move more frequently between jobs and/or between employment statuses. However, the data suggest that there are no substantial differences between graduates in the probability of having changed jobs, and that VET graduates are less likely than general education graduates to have moved with the goal to get a better job. Around half of the VET graduates who change occupations manage to move into occupations with higher skill or wage levels and lower risk of automation. This share is even higher among general and tertiary education graduates.

- Several occupations that employ many VET graduates, and especially the ones that employ mainly VET graduates, are facing excess supply (relative to demand) on average in European labour markets. This means that the short-term outlook for VET graduates is not very bright in some of their default occupations. However, a few typical VET jobs, like metal and machinery workers and electrical and electronic trades, are facing shortages in the EU on average. Moreover, employment in craft and related trades jobs in EU countries is projected to continue to decline in the medium term, which could imply that, if VET systems do not adapt, VET graduates might increasingly end up in sales and services occupations and elementary occupations (which continue to grow), or in high-skill occupations - provided that VET systems adapt to develop the required skills. In spite of a projected decline in total employment in craft and related trades jobs, a substantial number of job openings are still expected to be created in these occupations to fulfill replacement demand. One of the key drivers of these changes is automation. VET graduates work in jobs with a similar risk of automation as general education graduates, and this risk is lower than for those without an upper-secondary qualification, but it is substantially higher than the risk faced by tertiary education graduates. The difference between VET and tertiary education graduates can be linked to the fact that these two groups of graduates work in very different occupations, but even when employed in the same occupation, VET graduates carry out tasks that are more exposed to automation than tertiary education graduates'. The extent to which VET systems are responsive to changes in the labour market is crucial for ensuring that VET can prepare students for jobs that are in strong demand.

- For VET graduates to be resilient in a changing labour market, it is imperative that they have strong foundational skills. However, the OECD Survey of Adult Skills (PIAAC) shows that, in many countries, VET graduates have lower numeracy, literacy and problem-solving skills than general education graduates. Exceptions are the United States, Australia, Canada, Ireland and New Zealand, where VET is predominantly organised at the post-secondary non-tertiary level, but also Japan. While differences in cognitive skill are not surprising given the different scope of general and VET programmes, weak cognitive skills could hamper the adaptability of VET graduates in a changing labour market. In countries like Austria, Finland, the Netherlands, Norway and Sweden, VET graduates have slightly lower cognitive skill levels then general education graduates, but still very few among them have scores at the lowest level of the PIAAC test. While this could reflect a limited focus on general subject in some countries' VET systems, it could also be related to selection effects and shortcomings in the early years of education. At the same time, only a relatively limited share of VET graduates participate in job-related training, 
Nonetheless, they have seen stronger growth in training participation in the past ten years than other graduates.

Not all countries are facing the same issues for VET graduates, and a lot depends on the quality of the VET system and the ability of the system to adapt to changes. Countries where labour market outcomes of VET graduates are good in most dimensions include Austria, Denmark, Germany, Norway and Sweden. While these countries have very different VET systems, their common feature is that the ties between VET institutions and social partners are relatively strong. VET graduates in these countries might have had less problems in adapting to the global changes in the labour market. This suggests that cooperation between VET systems and the world of work is important to ensure that graduates enter the labour market with skills that correspond with labour market needs. Moreover, this strong coordination allows opening up the VET system to non-traditional fields of study that correspond to growing occupations and sectors, thus helping VET graduates access available job opportunities. Another feature of VET in the well-performing countries is that most programmes allow for access to higher education, either directly or through bridging programmes, and that several vocationally oriented programmes are available at the tertiary level.

Overall, the findings from this report suggest that in several countries VET systems will need to adapt to ensure that graduates have the skills that correspond to today's and tomorrow's labour market needs. VET graduates are not facing the same challenges in all countries, and the need for intervention depends on the specific quality of each VET system and its ability to adapt to changes. Close ties between the VET system and the world of work, as is the case in countries like Austria, Denmark, Germany, Norway, Sweden and Switzerland, is essential to ensure alignment with labour market needs. Expanding the offer of higher VET and developing smoother pathways into higher education, as well as opening up the VET system to non-traditional fields of study that correspond to growing occupations and sectors, like the recently introduced apprenticeships in the fields of software development, network engineering, and cybersecurity in Ireland, is needed to warrant that VET graduates can access available job opportunities. Strong skills assessment and anticipation systems are important to inform responsive VET policies. At the same time, VET systems, and the initial education system more broadly, need to invest in the development of strong foundational skills, so that graduates are more adaptable and find it easier to further develop their skills. Strong career guidance in education is crucial to help students make informed education and labour market choices.

For VET graduates who are already in the labour market and are faced with job loss or changes in the content of their jobs, sufficient training opportunities need to be available. These opportunities should be of high quality and aligned with labour market needs, while at the same time addressing the specific barriers that adults face when it comes to training participation. Adults need easy-to-access information about these opportunities and understand how training would help improve labour market outcomes. Finally, as elementary occupations and sales and services jobs represent a growing proportion of the labour market in general, and for VET graduates, and many of these jobs have relatively low pay and difficult working conditions, the quality of these jobs should be safeguarded. Ensuring that workers in these occupations have access to high performance working practices, including skills development and career progression opportunities, as well as decent pay, will be of crucial importance. 


\section{Résumé}

Sous l'effet de mégatendances mondiales, comme le progrès technologique et la mondialisation, les marchés du travail des pays de l'OCDE ont connu ces dernières décennies des changements structurels. Ceci a entraîné d'importants changements au niveau de la demande de compétences. En outre, de nombreux emplois, en particulier les emplois peu et moyennement qualifiés, risquent d'être automatisés dans les décennies à venir.

Le processus d'automatisation suscite des inquiétudes quant aux débouchés professionnels des diplômés de l'éducation et la formation professionnelles (EFP), étant donné qu'habituellement ces derniers occupent surtout des emplois à rémunération moyenne. Il ressort de travaux antérieurs que l'EFP contribue à réduire les taux de décrochage scolaire, surtout chez les élèves très vulnérables, et qu'elle facilite le passage de l'école à la vie active. Afin de conserver et renforcer l'impact positif que l'EFP peut avoir sur les résultats des élèves, dans un monde du travail en mutation, il serait peut-être nécessaire de repenser certains aspects des systèmes d'EFP, certainement dans des pays avec des systèmes d'EFP plus faibles. Le présent rapport exploite diverses sources de données sur les pays européens pour analyser la catégorie et la qualité des emplois occupés par les jeunes adultes (15-34 ans, appelés « les diplômés ») titulaires d'un diplôme professionnel au niveau secondaire du deuxième cycle ou au niveau post-secondaire non supérieur, et étudier les évolutions au fil du temps. Le devenir professionnel de ces diplômés de l'EFP à un niveau intermédiaire est comparé à celui des titulaires d'un diplôme général de même niveau, mais aussi à celui des diplômés du supérieur (quelle que soit la filière d'orientation) et des élèves non titulaires d'un diplôme du deuxième cycle du secondaire. Le présent rapport se concentre sur ces diplômés de l'EFP de niveau intermédiaire et ne s'intéresse donc pas à l'EFP organisé à des niveaux d'enseignement supérieurs ou inférieurs, ni à une formation non formelle à vocation professionnelle. Les principales conclusions sont les suivantes :

- L'EFP joue un rôle de premier plan dans les systèmes d'éducation et de formation des pays de l'UE. En moyenne, une personne sur trois âgée de 15 à 34 ans est titulaire d'un diplôme d'EFP de niveau intermédiaire (défini comme l'enseignement à finalité professionnelle au niveau secondaire du deuxième cycle ou post-secondaire non supérieur). Cependant, l'EFP occupe une place plus ou moins importante dans le système d'éducation et de formation selon les pays ; en effet, au niveau intermédiaire, l'EFP joue un rôle de premier plan dans des pays comme l'Allemagne, l'Autriche, la République slovaque et la République tchèque, et un rôle limité seulement dans des pays comme Chypre, l'Irlande ou Malte. La part de jeunes adultes titulaires d'un diplôme d'EFP de niveau intermédiaire a légèrement diminué en moyenne ces quinze dernières années. Les pays n'organisent pas non plus l'EFP de la même façon : certains pays font une large place à l'apprentissage en milieu de travail dans leurs programmes d'EFP (Allemagne, Autriche, Norvège et Suisse, par exemple) tandis que d'autres adoptent une approche essentiellement axée sur la formation en établissement (Finlande, Portugal et Slovénie, par exemple). La façon d'organiser et implémenter l'EFP a un impact sur sa qualité, ce qui agit sur l'attractivité de l'EFP et les résultats des diplômés sur le marché du travail. 
- À niveau d'études équivalent, les diplômés de l'EFP affichent des taux d'emploi plus élevés et des taux de chômage plus faibles que les diplômés de l'enseignement général. C'est notamment le cas en Allemagne, en Autriche, en Norvège, en Suède et en Suisse, où le devenir professionnel des diplômés de l'EFP est nettement meilleur que celui des diplômés de l'enseignement général. L'intensité du travail chez les premiers est également légèrement supérieure à celle des derniers. Les résultats des diplômés de l'EFP en termes de quantité d'emplois, par rapport aux diplômés de l'enseignement général, sont restés relativement stables ces quinze dernières années.

- Les diplômés de l'EFP affichent globalement les mêmes résultats que les diplômés de l'enseignement général en termes de qualité de l'emploi, pour la plupart des dimensions concernées. Les diplômés de l'EFP enregistrent en moyenne des niveaux de rémunération légèrement supérieurs à ceux des diplômés de l'enseignement général, et cet écart de salaire est particulièrement prononcé dans des pays comme le Danemark, l'Islande et la Norvège. D'un autre côté, les salaires des diplômés de l'EFP sont nettement inférieurs à ceux des diplômés de l'enseignement supérieur, même lorsqu'ils occupent des emplois similaires. Les diplômés de l'EFP sont moins susceptibles que les diplômés de l'enseignement général d'occuper des emplois temporaires durant les premières années qui suivent l'obtention de leur diplôme, bien que cette différence d'accès à des emplois permanents disparaît si l'on regarde les diplômés qui ont achevé leurs études il y a plus de dix ans. En ce qui concerne la qualité du cadre de travail, les diplômés de l'EFP effectuent plus souvent des tâches exigeantes sur le plan physique que les diplômés de l'enseignement général. Dans le même temps, les deux groupes sont tout autant susceptibles de faire l'expérience de pratiques de travail à rendement élevé et d'avoir des responsabilités d'encadrement.

- Un peu plus d'un quart des diplômés de l'EFP travaillaient dans les métiers des services et de la vente en 2017, et un quart supplémentaire dans les métiers qualifiés de l'industrie et de l'artisanats. Environ $18 \%$ des diplômés de l'EFP occupent des emplois hautement qualifiés, contre $26 \%$ des diplômés de l'enseignement général. Cependant, la part des jeunes diplômés de l'EFP dans les professions hautement qualifiées est supérieure à un tiers en Allemagne, à Malte et en Suisse. Les diplômés de l'EFP sont moins susceptibles que les diplômés de l'enseignement général de faire état d'une formation insuffisante pour leur emploi et sont plus susceptibles d'occuper des emplois qui correspondent à leur niveau d'études. Près d'un diplômé de l'EFP sur quatre occupe un emploi qui ne correspond pas à son domaine d'études, ce qui est similaire aux diplômés de l'enseignement supérieur.

- La composition professionnelle de l'emploi des diplômés de l'EFP a connu des changements importants ces quinze dernières années. Tout d'abord, les diplômés de l'EFP sont aujourd'hui plus susceptibles de travailler dans les métiers des services et de la vente qu'il y a quinze ans. La progression de ces emplois chez les diplômés de l'EFP peut s'expliquer par l'importance croissante des emplois dans la vente et les services sur l'ensemble du marché du travail, et par le fait que la part des diplômés de l'EFP dans ces métiers est plus élevée. Cette progression des métiers de la vente et des services s'accompagne d'une part croissante de diplômés spécialisés dans les services et dans les domaines de la santé et du bien-être. Ensuite, malgré un important recul global de l'emploi dans les métiers qualifiés de 
l'industrie et de l'artisanats, la part des diplômés de l'EFP dans ces métiers, exprimée en pourcentage du nombre total de diplômés de l'EFP, est restée stable. Par conséquent, les vacances d'emploi qui restent disponibles dans ces métiers sont de plus en plus pourvues par des diplômés de l'EFP, mettant en avant l'avantage comparatif que les diplômés de l'EFP tiennent dans ce domaine. Enfin, en dépit de la forte croissance de l'emploi total dans les professions hautement qualifiées, la part des diplômés de l'EFP occupant des emplois hautement qualifiés a légèrement diminué en moyenne dans tous les pays. On observe toutefois des différences importantes entre les pays et, en Allemagne et en Suisse, par exemple, la part (déjà relativement importante) des diplômés de l'EFP qui occupent des professions intermédiaires a augmenté ces quinze dernières années.

- Alors que le marché du travail pour les diplômés de l'EFP est en train de connaître de profondes mutations, on pourrait s'attendre à ce que ces diplômés changent plus souvent d'emploi et/ou de situation au regard de l'emploi. Cependant, les données laissent penser qu'il n'y a pas de différences majeures entre les diplômés eu égard à la probabilité de changer de travail, et que les diplômés de l'EFP sont moins susceptibles que leurs camarades de l'enseignement général de changer pour un emploi de meilleure qualité. Environ la moitié des diplômés de l'EFP qui changent de profession parviennent à accéder à des professions avec des niveaux de compétence ou de salaire plus élevés et un risque d'automatisation plus faible. Cette part est encore plus élevée parmi les diplômés de l'enseignement général et supérieur.

- Parmi les professions qui emploient de nombreux diplômés de l'EFP, et notamment celles qui emploient principalement des diplômés de l'EFP, plusieurs connaissent actuellement une offre excédentaire (par rapport à la demande) en moyenne sur les marchés du travail européens. Cela signifie que les perspectives à court terme pour les diplômés de l'EFP sont peu encourageantes dans certains de leurs secteurs d'activités par défaut. Toutefois, quelques métiers classiques des filières d'EFP, comme la métallurgie, la construction mécanique, l'électricité et l'électrotechnique, font face à des pénuries dans l'UE en moyenne. En outre, l'emploi dans les métiers qualifiés de l'industrie et de l'artisanat dans les pays de l'UE devrait continuer de décliner à moyen terme. Il pourrait s'ensuivre que, si les systèmes d'EFP ne s'adaptent pas, les diplômés de l'EFP finiront de plus en plus par exercer les métiers du commerce, de la vente et des services et des professions élémentaires (qui continuent de se développer), ou bien par occuper des emplois très qualifiés à condition que les systèmes d'EFP s'adaptent pour les doter des compétences requises. Malgré une baisse prévue de l'emploi dans les qualifiés de l'industrie et de l'artisanat, un nombre important de postes devraient encore être créés dans ces professions pour répondre à la demande liée aux départs en fin de carrière. L'un des principaux facteurs de ces changements est l'automatisation. Le risque d'automatisation des emplois est le même chez les diplômés de l'EFP et chez les diplômés de l'enseignement général; il est moins élevé que pour les individus n'ayant pas achevé le deuxième cycle du secondaire, mais largement plus grand que pour les diplômés du supérieur. L'écart entre les diplômés de l'EFP et les diplômés du supérieur peut être lié au fait que ces deux groupes travaillent dans des métiers très différents, et que, même lorsqu'ils occupent des emplois similaires, les premiers effectuent des tâches qui risquent davantage d'être automatisées. La mesure dans laquelle les systèmes d'EFP sont sensibles aux changements du marché 
du travail est cruciale pour garantir que l'EFP puisse préparer les étudiants à des emplois en forte demande.

- Pour favoriser la résilience des diplômés de l'EFP sur un marché du travail en mutation, il est impératif de les doter d'un socle de compétences solide. Toutefois, l'Enquête de l'OCDE sur les compétences des adultes (PIAAC) montre que, dans de nombreux pays, les diplômés de l'EFP ont un niveau de compétences en littératie, en numératie et en résolution de problèmes qui est inférieur à celui des diplômés de l'enseignement général. Quelques pays font exception, à savoir 1'Australie, le Canada, les États-Unis, l'Irlande et la Nouvelle-Zélande, où l'EFP est essentiellement organisé au niveau postsecondaire non supérieur, mais également le Japon. Même si des différents niveaux de compétences cognitives ne sont pas inattendus étant donné la différente portée des programmes de l'enseignement générale et de l'EFP, des faibles compétences cognitives peuvent limiter l'adaptabilité des diplômés de l'EFP dans un marché du travail en mutation. Dans les pays comme l'Autriche, la Finlande, la Norvège, les Pays-Bas et la Suède, les diplômés de l'EFP possèdent des compétences cognitives légèrement inférieures à celles des diplômés de l'enseignement général, mais rares sont ceux, toutefois, à se classer dans la fourchette de résultats la plus basse au test du PIAAC. Bien que cela puisse refléter une focalisation limitée sur des matières générales dans les systèmes d'EFP de certains pays, cela pourrait également être lié aux effets de sélection et aux lacunes dans les premières années de l'éducation. Dans le même temps, seule une part relativement limitée des diplômés de l'EFP participe à des formations liées à l'emploi. Toutefois, le taux de participation à la formation a davantage augmenté chez ces derniers que chez les autres diplômés ces dix dernières années.

Les pays ne sont pas tous confrontés aux mêmes problématiques eu égard aux diplômés de l'EFP, et la situation varie beaucoup en fonction de la qualité du système d'EFP et de sa capacité à s'adapter aux changements. Parmi les pays où les débouchés professionnels des diplômés de l'EFP sont satisfaisants dans la plupart des dimensions figurent l'Autriche, le Danemark, l'Allemagne, la Norvège et la Suède. Si ces pays disposent de systèmes d'EFP très différents, leur caractéristique commune est que les liens entre les établissements d'EFP et les partenaires sociaux sont relativement forts. Les diplômés de l'EFP dans ces pays rencontreraient moins de difficultés pour s'adapter à l'évolution mondiale du marché du travail. Cela montre que la coopération entre les systèmes d'EFP et le monde du travail est importante pour permettre aux diplômés d'entrer sur le marché du travail dotés des compétences recherchées par les employeurs. De plus, cette étroite coordination permet d'ouvrir le système d'EFP à des domaines d'études non traditionnels qui correspondent aux secteurs et activités en plein essor, ce qui facilite l'accès des diplômés de l'EFP aux emplois disponibles. Une autre caractéristique de systèmes d'EFP dans les pays performants est que la plupart des programmes donnent accès à l'enseignement supérieure, soit directement ou à travers des programmes de transitions, et que plusieurs programmes professionnels sont disponibles au niveau supérieure.

Dans l'ensemble, les conclusions du présent rapport laissent penser que, dans de nombreux pays, les systèmes d'EFP devront s'adapter pour veiller à doter les diplômés de compétences adaptées aux besoins actuels et futurs du marché du travail. Les diplômés de l'EFP ne font pas face aux mêmes enjeux dans tous les pays, et la nécessité de reconcevoir certains aspects des systèmes d'EFP dépend de leur qualité et leur capacité d'adaptation. Il est essentiel d'établir des liens étroits entre le système d'EFP et le monde du travail, comme l'ont déjà fait des pays comme l'Allemagne, l'Autriche, le Danemark, la Norvège, la Suède 
et la Suisse, pour mettre en adéquation l'offre et la demande d'emplois. Il est en outre nécessaire d'élargir l'offre d'EFP supérieur et d'assouplir les voies d'accès à l'enseignement supérieur aussi bien qu'ouvrir le système d'EFP à des domaines d'études non traditionnels qui correspondent aux secteurs et activités en plein essor, comme les formations en apprentissage proposées depuis peu en Irlande dans les domaines du développement de logiciels, de l'ingénierie de réseau et de la cybersécurité, pour que les diplômés de l'EFP puissent accéder aux vacances d'emploi disponibles. De solides systèmes d'évaluation et d'anticipation des compétences sont importants pour éclairer les politiques d'EFP réactives. Dans le même temps, les systèmes d'EFP, et le système d'éducation initiale plus largement, doivent investir dans l'acquisition d'un socle de compétences solide, pour améliorer l'adaptabilité des diplômés et faciliter le perfectionnement de leurs compétences. Des services d'orientation efficaces sont essentiels pour aider les étudiants à faire des choix éclairés quant à leurs études et leur carrière professionnelle.

Pour les diplômés de l'EFP qui sont déjà sur le marché du travail et qui sont confrontés à une perte d'emploi ou des changements eu égard au contenu de leur emploi, il est impératif qu'une offre suffisante de formation soit disponible. Cette offre devrait être de très bonne qualité et correspondre aux besoins du marché du travail, tout en s'attaquant aux obstacles spécifiques que rencontrent les adultes pour participer à la formation. Les adultes doivent en effet pouvoir accéder facilement à l'information sur les possibilités de formation et comprendre l'intérêt de cette démarche pour améliorer leur situation professionnelle. Enfin, étant donné que les professions élémentaires et les métiers du commerce, de la vente et des services représentent une part croissante du marché du travail en général, et pour les diplômés de l'EFP en particulier, et que certains de ces emplois sont relativement peu rémunérateurs et offrent des conditions de travail difficiles, la qualité de ces emplois devrait être préservée. S'assurer que les travailleurs dans ces secteurs d'activité ont accès à des pratiques de travail à rendement élevé, notamment à des possibilités d'amélioration des compétences et de progression de carrière, mais aussi à un salaire décent, sera alors d'une importance capitale. 


\section{Acronyms and abbreviations}

AES

EU

HPWP

ICT

ISCED

ISCO

LFS

NEET

OECD

PIAAC

PISA

RPL

SILC

VET
Adults Education Survey

European Union

High Performance Work Practices

Information and Communication Technology

International Standard Classification of Education

International Standard Classification of Occupations

Labour Force Survey

Not in Employment, Education or Training

Organisation for Economic Co-operation and Development

Programme for the International Assessment of Adult Competencies

Programme for International Student Assessment

Recognition of Prior Learning

Survey on Income and Living Conditions

Vocational Education and Training 


\section{Chapter 1. Introduction}

In recent decades, the educational attainment of populations in OECD countries has increased significantly. While only $20 \%$ of adults in OECD countries had a tertiary education degree at the end of the $20^{\text {th }}$ century, this share now reaches $37 \%$ (see Figure 1.1 ). Only $21 \%$ of adults do not have an upper secondary education degree, compared to $37 \% 20$ years ago. These trends have significantly altered the supply of skills.

Figure 1.1. Trends in educational attainment

Share of population aged 25-64 (OECD average)

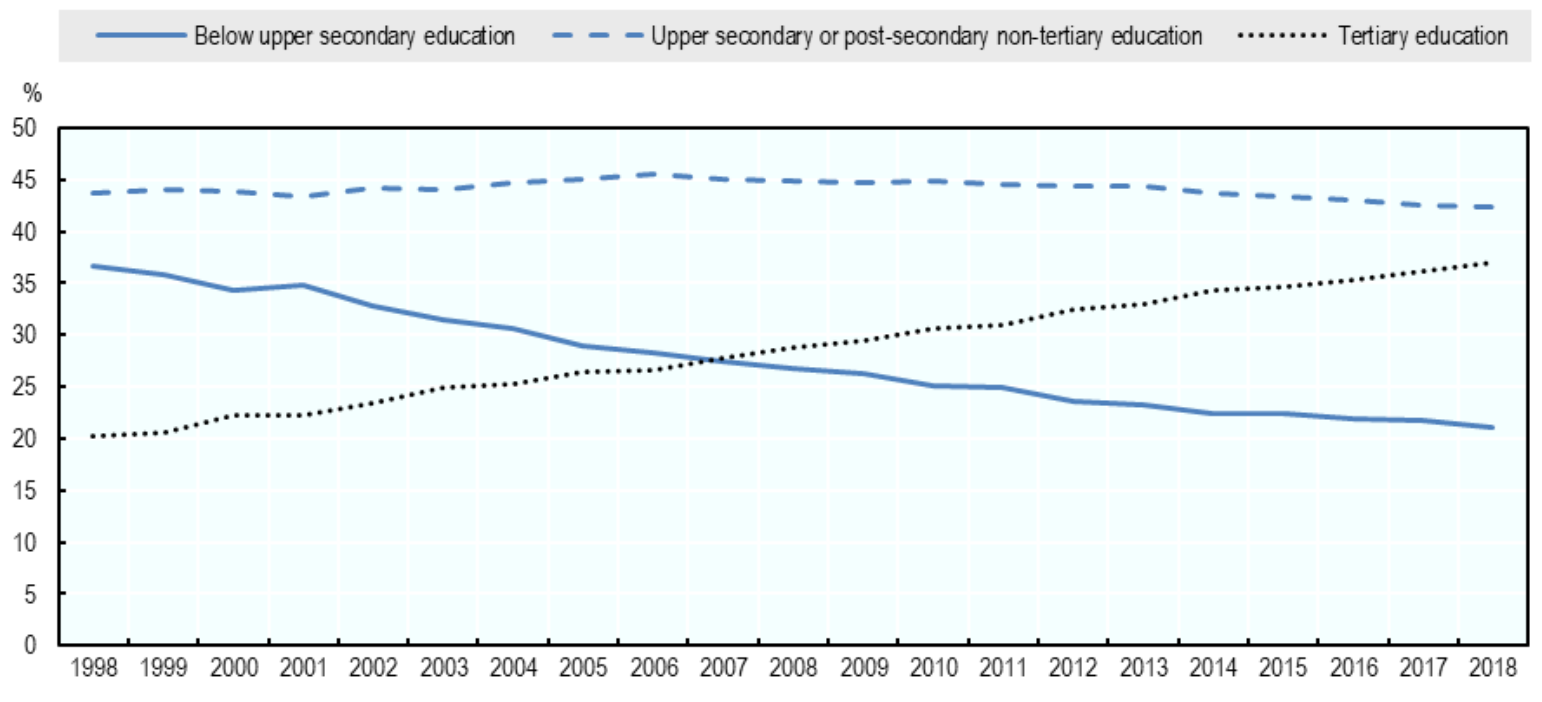

Source: OECD Education at a Glance database.

At the same time, the demand for skills in developed countries has changed in the last decades, as a consequence of structural changes in the labour market, such as technological progress and globalisation. As argued by Goos and Manning (2007 $\left.{ }_{[1]}\right)$ and Autor, Katz and Kearney $\left(2006_{[2]}\right)$ technological change has been routine-biased, implying that jobs that are highly routine in content can be substituted for by technology. These routine-intensive jobs are mainly found in the middle of the wage distribution. Jobs at the higher end of the distribution are generally much less routine-intensive, as they often involve abstract thinking, creativity and social interaction. Moreover, in these jobs, technology is complementary to labour, rather than being able to displace it. Finally, jobs at the bottom end of the wage distribution are also mostly non-routine, as they involve unstructured manual tasks and social interaction.

This process of job polarisation has been documented extensively for the United States and European countries. For example, when ranking occupations by their 1980 wage, Autor and Dorn $\left(2013_{[3]}\right)$ find that occupations at the top and bottom of the distribution experience growth in their employment shares in the period 1980-2005, whereas the employment share of occupations in the middle of the wage distribution declined. Similarly, Goos, Manning and Salomons $\left(2014_{[4]}\right)$ find that job polarisation was pervasive across 16 European countries in the period 1993-2010, with the employment share of high-wage and low-wage 
occupations increasing and that of middle-wage occupation decreasing. It is important to note that these data refer to relative changes, and therefore do not give insight into whether or not employment levels in middle-skill jobs declined. According to Eurofound (2019 $9_{[5]}$ ), employment levels in middle-wage jobs in EU countries have gone up in the period 1998-2018, but to a lesser extent than employment levels in low- and high-wage jobs.

Recent evidence suggests that the pattern of job polarisation has been changing over time, and that not all developed countries have experienced the same pattern of employment growth in different time periods. Autor $\left(2015_{[6]}\right)$ shows that in the United States, the pattern evolved from having the strongest employment growth at the top of the wage distribution in the 1980s, over balanced growth in both high-wage and low-wage jobs in the 1990s, to growth being concentrated mostly in low-wage jobs in the period 2000-2012. According to Autor $\left(2015_{[6]}\right)$, the slow-down in employment growth at the top can be linked to falling investments in innovation in the 2000s. Similarly, for European countries, Eurofound $\left(2017_{[7]}\right)$ shows that employment growth in the post-recession years (2013-2016) was on average only modestly biased towards the highest-wage jobs, which is very different from the pattern observed before the recession. Moreover, they find that patterns not only differ between time periods, but also between countries, with some countries demonstrating employment polarisation patterns, and others upgrading or downgrading. Looking at the period ahead, Cedefop employment projections for the period 2016-2030 suggest that jobs openings will be created available at all wage or skill levels, but mostly so at the highest level ( $46 \%$ of all projected job openings will be for managers, professionals and technicians and associate professionals $)^{1}$. While job openings will be found in all occupation groups, mostly due to replacement demand, total employment is project to go down in clerical, skilled agricultural, and crafts and related trades occupations. However, this fall in employment levels is small relative to the total number of job openings in those occupations.

Although most of the research on job polarisation links employment changes to wage levels to determine which type of jobs are experiencing the strongest relative employment growth, wages have often been used as a proxy for skill level. As such, the messages coming from this strand of research have often focused on the fact that middle-skill jobs are becoming less important in the labour market (see for example Autor and Dorn (2013 $\left.{ }_{[3]}\right)$, Autor $\left.\left(2015_{[6]}\right)\right)$. Data on literacy proficiency and wages of workers by occupation from the OECD Survey of Adult Skills (PIAAC) show that these are generally highly correlated. However, there are some important inconsistencies between the ranking of occupations based on skill and wage level. ${ }^{2}$ This is particularly the case for service and sales occupations, which have low wages on average across countries (except for protective services workers), but skill levels that are in line with middle-wage occupations. However, workers in sales and services occupations are more often overqualified for their job (and less often underqualified) than workers in other middle-skill occupations (i.e. clerical support workers, craft and related trades workers, and plant and machine operators and assemblers), signalling that the skill requirements in those jobs might be lower than the skill levels of the current workers. Because of the particularities of the group of Sales and

\footnotetext{
${ }^{1}$ Other occupation groups that are projected to have a large number of job openings are sales and service occupations ( $16 \%$ of all openings) and elementary occupations (12\% of openings). Job openings for clerical workers and crafts and related trades workers represent each $8 \%$ of total openings, while plant and machine operators and assemblers account for $6 \%$ of total job openings.

${ }^{2}$ See Eurofound $\left(2017_{[7]}\right)$ for a discussion on how the pattern of employment changes differs when using average wages or education levels to rank jobs.
} 
Services workers, different approaches have been used to classify them, with some labelling them as low-skill (e.g. OECD $\left(2017_{[8]}\right)$ ) and others as middle-skill occupations (e.g. Cedefop and Eurofound (2018[9] $)$ ).

As technological progress continues, it could be expected that an increasing share of jobs are impacted by these changes. Frey and Osborne $\left(2017_{[10]}\right)$ were the first to estimate the risk of automation for different occupations based on expert opinions and the identification of bottleneck tasks, such as social intelligence, creativity, perception and manipulation. Their estimates suggest that $47 \%$ of jobs in the United States are at high risk of automation. Applying the same methodology, similar estimates were found for European and other OECD countries. Arguing that there are substantial differences in the tasks carried out in different jobs in the same occupations, Arntz, Gregory and Zierahn $\left(2017_{[11]}\right)$ and Nedelkoska and Quintini $\left(2018_{[12]}\right)$ refined the methodology to estimate automation risk at the individual level rather than the occupation level. Nedelkoska and Quintini $\left(2018_{[12]}\right)$ show that $14 \%$ of jobs across OECD countries have a high risk of automation. An additional $32 \%$ has a medium risk, implying that they are likely to undergo significant changes as opposed to disappearing entirely.

The estimated risk of automation differs strongly between occupations (see Figure 1.2). Food preparation assistants, cleaners and helpers, labourers in mining, construction, manufacturing and transportation, and assemblers are the occupations that face on average the highest risk of automation. The lowest risk is observed for teaching professionals, managers and health professionals. While most of the low-risk occupations are high-skill, some lower-skill occupations, like personal care and protective services workers, also face a relatively low risk of automation. 
Figure 1.2. Average risk of automation, by occupation

Average estimated probability of automation (0-1), OECD average

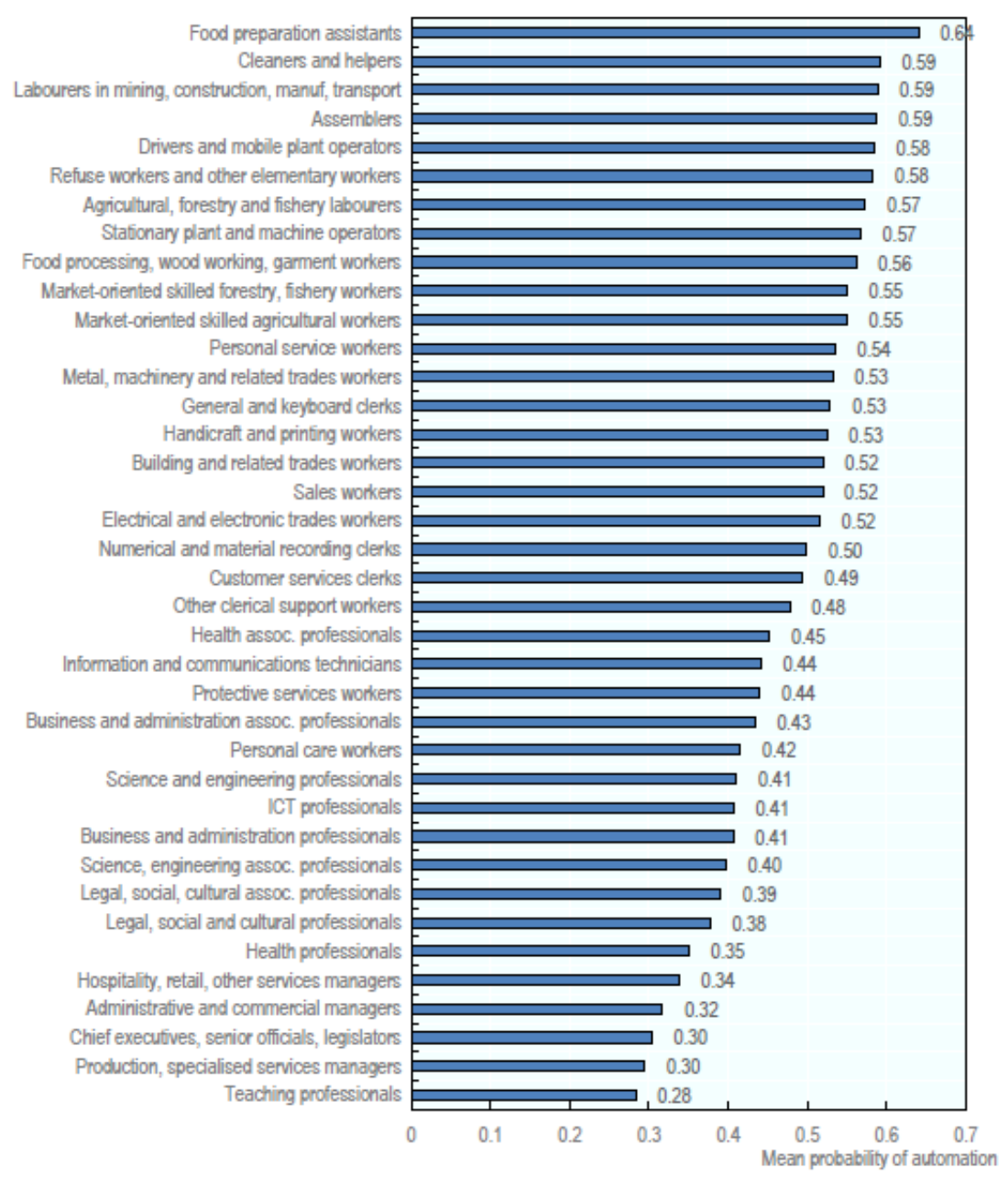

Note: Average of PIAAC countries.

Source: Nedelkoska and Quintini (2018[12])

With many jobs affected by technological progress requiring mid-level skills, the question arises as to what extent VET graduates are impacted by these changes. On the one hand, VET is generally seen as preparing individuals for mid-level jobs, and some of these graduates might therefore see suitable job opportunities shrink polarisation. Green $\left(2019_{[13]}\right)$ indeed shows that routine jobs were mainly carried out by workers without a tertiary degree before the start of the polarisation trend (roughly around 1995). The typical worker in routine occupations held at least an upper-secondary degree with some further schooling, although also many workers without an upper-secondary degree were employed in these occupations. The majority of routine workers were men. Cedefop $\left(2013_{[14]}\right)$ finds that VET graduates at upper-secondary level are more likely than their general education counterparts to work in skilled manual jobs (e.g. craft and related trades workers, plant and machine operators and assemblers), but not more likely to work in skilled non-manual jobs (e.g. clerical support workers) or in high-skill jobs. As many skilled manual jobs have a relatively high risk of automation (see Figure 1.2), this could imply that VET graduates are particularly vulnerable to automation risk if the VET offer and content does not adapt. 
However, a study for Finland shows that admission to the vocational track is not associated to a higher risk of automation and offshoring compared to general track admission (Silliman and Virtanen, 2019 ${ }_{[15]}$ ). On the other hand, responsive VET systems are able to respond to changing skill needs in the labour market and could therefore be well-placed to prepare students for the jobs that are in demand.

Most studies that look at labour market outcomes for VET graduates show that VET helps graduates with their transition from school to work. Brunello and Rocco $\left(2017_{[16]}\right)$, for example, find that upper-secondary and post-secondary non-tertiary education graduates from a vocational field have slightly lower wages, but better employment outcomes than graduates from general fields, both through higher probabilities of employment at the time of the interview and larger shares of completed working life spent in paid employment. However, these positive employment effects seem to disappear for older age groups. This is consistent with findings from Forster, Bol and van de Werfhorst $\left(2016_{[17]}\right)$ and Hanushek et al. $\left(2017_{[18]}\right)$, who show that individuals with a vocational qualification have a higher employment probability than those with a general qualification at the start of their career, but this pattern reverses later in life. Verhaest et al. $\left(2018_{[19]}\right)$ show that VET graduates at the start of their career are less likely to be mismatched by qualification and have a lower degree of over-skilling compared to general education graduates, but that this advantage declines with time elapsed since graduation. They conclude that VET graduates are more employable when they leave initial education because of the labour market focus of their qualification, but that their skills gradually become obsolete because of structural and organisational changes in the labour market. Hanushek et al. $\left(2017_{[18]}\right)$ find that VET graduates participate less in job-related training, and argue that this might lead to skills obsolescence which could be one of the reasons for poorer employment outcomes later in life. In addition, they link the decreasing employment advantage for VET graduates to poorer basic skills and hence lower adaptability. Brunello and Rocco $\left(2017_{[16]}\right)$ indeed find that VET graduates have lower basic skills than graduates from general fields. However, this declining advantage for VET graduates is not found in all countries. Silliman and Virtanen $\left(2019_{[15]}\right)$, for example, show that admission to the vocational track in Finland significantly increases annual income compared to the general education track, and that these benefits do not diminish with time. The strong performance of VET in facilitating school-to-work transitions suggest that strong VET systems could also help protect youth from unemployment during crises. Youth unemployment is traditionally low in Austria, Germany and Switzerland, which are known as the "apprenticeship countries" (OECD, $\left.2010_{[20]}\right)$. Even in the global financial crisis, these countries have succeeded in keeping unemployment down, with youth unemployment rates hardly increasing during the crisis. In 2009 , their youth unemployment rates were respectively $10 \%, 11 \%$ and $8 \%$, compared with $19 \%$ on average in the OECD. The key elements behind their success could be related to fine-tuning measures to secure on-the-job training for all apprentices, even low achievers.

In addition to smoothening the transition from school to work, VET has been shown to contribute to reducing high-school dropout rates. In the United States, Kulik (1998[21]) shows that high-risk students are eight to ten times less likely to drop out in the 11th and 12th grades if they enrol in a Career Technical Education (CTE) programme. Also for the United States, Plank, DeLuca and Estacion $\left(2005_{[22]}\right)$ find that students who enrol in some CTE courses have a lower risk of dropping out, but that students who enrol in curricula that are too heavily focused on CTE courses have a higher probability of dropping out. For Portugal, Henriques et al $\left(2018_{[23]}\right)$ show that take-up of vocational courses is linked to a lower probability of dropout for low-ability students, but increases the dropout probability 
for high-ability students. Analysis of international cross-sectional data finds that nations enrolling a large proportion of upper-secondary students in vocational programmes have significantly higher school attendance rates and higher upper-secondary completion rates (Bishop and Mane, 2004 [24]). While most of the research points towards a negative association between VET and high-school dropout, some research also finds no effect of VET on dropout (e.g. Agodini and Deke $\left(2004_{[25]}\right)$ for the United States).

With VET having the capacity to engage students in learning and to facilitate their entry into the labour market, it is of crucial importance to ensure that VET systems and their graduates are resilient in a changing world of work. This paper analyses how labour market outcomes of young middle-educated VET graduates (aged 15 to 34) in European countries have changed in recent years, highlighting the difference between outcomes of graduates from vocational tracks in upper secondary and post-secondary education, and graduates from general tracks at the same level. It starts with an extensive discussion of today's profile of VET graduates and their labour market outcomes, including job quantity and quality indicators. To analyse the extent to which the labour market has changed for these graduates, the paper uses historic Labour Force Survey (LFS) data to see how outcomes have evolved over time, with a particular focus on changes in the occupational structure of employment. Given that certain VET graduates are likely to be substantially affected by changes in the labour market, longitudinal data (EU-SILC) are used to analyse job mobility of VET graduates. Based on employment projections, skills imbalances and automation risk in jobs and occupations carried out by VET graduates, the paper also looks at the perspectives for the future for these graduates. Based on these findings, the final section of the paper looks at policy implications related to re-engineering VET systems to ensure that they are future-ready. 


\section{Chapter 2. Defining vocational education and training}

Vocational education and training (VET) is a comprehensive term commonly used to refer to education, training and skills development in a wide range of occupational fields, production, services and livelihoods. Many VET programmes may have work-based components (e.g. apprenticeships, dual-system education programmes), but vocational programmes can also be entirely school-based. Successful completion of vocational programmes leads to labour market-relevant, vocational qualifications acknowledged as occupationally-oriented by the relevant national authorities and/or the labour market (OECD, 2018[26]).

This paper compares middle-educated VET graduates to graduates from general education at the same level. Therefore, in this report, vocational education graduates include all graduates who have obtained at most an upper secondary education qualification (i.e. ISCED-3) or a post-secondary non-tertiary education qualification (i.e. ISCED-4) which was vocationally oriented. General education graduates have a qualification at the same level (ISCED-3 or 4), but which is not vocationally oriented. For comparison, the analyses also include tertiary education graduates (i.e. all graduates with a qualification higher than ISCED-4, irrespective of the orientation of that qualification) ${ }^{3}$ and individuals who did not complete upper secondary education. Therefore, when this report refers to 'VET graduates', it only includes those who have a mid-level vocationally-oriented qualification and not to graduates with a vocationally- or professionally-oriented tertiary education qualification or to graduates from lower-secondary vocational programmes. As such, the focus of the report is only on a subset of the entire VET system. The analyses focus on the age group of 15 to 34 year-olds, who will be referred to as 'graduates' throughout the report. Individuals who are still in formal education are excluded from the analysis. ${ }^{4,5}$

It is usually not straightforward to distinguish VET graduates and general education graduates (at ISCED levels 3 and 4) in typical datasets, such as labour force surveys. Information on educational attainment is often restricted to the highest obtained

\footnotetext{
${ }^{3}$ While in principle it is also possible to separate tertiary-level qualifications into vocationally oriented and general qualifications, the distinction is less obvious than at lower levels of education. Indeed, ISCED levels 6 to 8 (bachelor's, master's and doctoral degrees) do not make the distinction between general and vocational in the absence of internationally agreed definitions on these orientation categories (OECD/Eurostat/UNESCO Institute for Statistics, $\left.2015_{[105]}\right)$. Therefore, in this report no distinction is made between vocational and general tertiary education, and when referring to tertiary education graduates this includes all graduates from ISCED level 5 and above.

${ }^{4}$ Being in education is defined as being a student/apprentice in formal education (in EU-LFS, PIAAC and EU-SILC data). Only in the panel analyses that use EU-SILC data, individuals are said to be in education if their self-reported current main activity status is 'pupil, student, further training, unpaid work experience'.

${ }^{5}$ These restrictions imply that in some countries and education groups sample sizes become small. As a general rule in this report, results from cells with less than 50 observations are not reported. Unweighted averages reported in tables and figures (referred to as "Average") are only based on countries with at least 50 observations for the presented indicator. EU averages are weighted and include all available observations. See Annex B for details on the construction of cross-country averages.
} 
qualification and the field of that qualification. While in some countries this information can be used to determine whether a respondent's highest qualification is general or vocationally oriented, additional information is sometimes needed to make that distinction. Box 2.1 describes how the orientation of individuals' highest obtained qualification is derived in the main data sources used in this paper. One important shortcoming of most available datasets is that they only provide information about the highest obtained qualification and not about the qualification obtained before that (see Kís (forthcoming ${ }_{[27]}$ ) for an elaborate discussion of this issue). This makes it impossible in those datasets to look at pathways between secondary education and tertiary education. This report does therefore not analyse how successful VET graduates are at entering and completing higher education.

\section{Box 2.1. Definition of mid-level VET}

\section{VET in the EU-LFS}

In the EU-LFS data, VET programmes are identified based on individuals' highest obtained qualification. Since 2014, national qualifications at ISCED-levels 3 and 4 are classified as 'vocational' or 'general' programmes, based on the national ISCED mappings (Eurostat, $2016_{[28]}$ ) and/or self-reporting by the individual (Eurostat, 2013 ${ }_{[29]}$ ). The VET identifier is only available for individuals younger than 35 and for individuals older than 34 who completed their highest educational level at most 15 years before the date of the interview.

This report uses the VET identifier to construct an indicator variable for VET in the years prior to 2014 as well. The post-2014 data are used to classify each combination of education level and education field as either vocational or general (by country). All fields of study where more than $50 \%$ of the graduates at a certain educational level indicate that their study programme was vocational, are classified as vocational programmes. This is done for each country separately. This classification is then used in the years prior to 2014 to label education fields and levels as either vocational or general. ${ }^{6}$

For the vast majority of countries, the mapping of fields of study into vocational or general programmes is perfect, with $100 \%$ of the graduates of the same field of study at an educational level having completed either vocational or general programmes. However, there are some exceptions. In France (ISCED 3), Malta (ISCED 3), Sweden (ISCED 3 and 4) and Cyprus (ISCED 3), the fields of study are not detailed enough to disentangle VET from general programmes (see Annex A). In those cases, field-level combinations that have at least 50\% VET graduates are entirely classified as VET (leading to an overestimation of the share of VET prior to 2014), and field-level combinations with less than 50\% VET graduates are classified as general (leading to an underestimation of the share of VET prior to 2014).

\section{VET in EU-SILC and PIAAC}

The other main datasets used in this report both contain direct information on whether or not the highest obtained qualification was general or vocationally-oriented. In EU-SILC, information on the level of the highest obtained qualification includes since 2014 a distinction between general and vocational education for ISCED levels 3 and 4, but only

\footnotetext{
${ }^{6}$ Note that this assumes that, within each country, the mapping of fields and levels of study into vocational or general programmes has remained relatively stable within our data window (i.e. 20032017).
} 
for individuals aged 16 to 34 . Because EU-SILC does not contain information on fields of study, the distinction between VET and general cannot be derived in the years prior to 2014 as is done in the EU-LFS. In the Survey of Adult Skills (PIAAC) a derived VET variable indicates whether or not the highest obtained qualification was vocational, at ISCED levels 3 and 4 and for all age groups. This variable was derived from the question on the name of the highest obtained qualification by national experts.

Note: See Annex A for more details on how VET is identified in the main datasets

Two important things need to be taken into account regarding the comparison of graduates. First, an international comparison of VET graduates can be challenging because countries differ strongly in the way they organise VET (e.g. in the extent of workplace exposure). This means that an international comparison of VET graduates will inevitably be based on groups of graduates with a potentially different educational background (see Box 2.2 for a short description and Kís (forthcoming ${ }_{[27]}$ ) for an elaborate discussion). Second, while the seemingly most obvious comparison group for VET graduates are graduates who pursued the general track at the same level, these general education graduates are in fact a rather particular group. Since general programmes in upper-secondary (and post-secondary non-tertiary) education are designed for students to gain access to tertiary education, and most of these graduates indeed continue their studies, the general education graduates analysed in this report (i.e. those who did not continue to and completed higher education levels) represent a somewhat specific sub-group of all graduates from upper-secondary general education programmes. That is why this report not only shows comparisons between VET and general education graduates, but also between VET and those with either a lower or higher qualification level.

To analyse labour market outcomes of VET graduates compared to graduates from general and tertiary education, as well as those without an upper secondary education degree, this paper uses data from three large scale surveys: the European Union Labour Force Survey (EU-LFS), the OECD Survey of Adult Skills (PIAAC), and the European Survey on Income and Living Conditions (EU-SILC).

The EU-LFS is a large household survey that is conducted in the 27 EU Member States plus Iceland, Norway, Switzerland and the United Kingdom. ${ }^{7}$ It contains information on labour market participation of people aged 15 and over. The data collection covers the years from 1983 onwards, or from the accession date of the EU Member State (Eurostat, n.d.[30]). Detailed information on the field of the highest obtained educational qualification and the orientation for that qualification (i.e. general or vocational) became available in 2003 and 2014 , respectively, and only covers individuals under 35 years old or who obtained their highest qualification at most 15 years prior to the survey (see Box 2.1 for details).

The OECD's Survey of Adult Skills (PIAAC) contains information on cognitive skills of adults in 37 countries (including 21 EU countries) ${ }^{8}$, as well as details on the use of skills,

\footnotetext{
${ }^{7}$ For analyses based on EU-LFS, EU-SILC and AES data, Eurostat's scientific use files are used. The responsibility for all conclusions drawn from the data lies entirely with the authors.

8 The data for the non-OECD countries that are not EU member states (i.e. Ecuador, Kazakhstan, Peru, Russian Federation and Singapore) are not used in this report. The 37 countries also include countries for which only certain sub-national entities participated. This is the case for Belgium
} 
the type of tasks carries out on the jobs, training participation and a range of background variables. The survey was administered in 2011-2012 in the majority of participating countries, with a few countries being added in 2014-2015 and then again in 2017. As this survey has only been carried out once in each country, it only gives a snapshot of the situation and cannot be used to analyse trends. ${ }^{9}$

Finally, the EU-SILC is a panel dataset that contains information on individuals in EU countries for four consecutive years, in the areas of education, health, income and labour. The EU-SILC data are mainly used in this paper to analyse dynamics, as -in contrast to PIAAC and EU-LFS data- the survey allows to track individuals over multiple years.

\section{Box 2.2. Understanding international differences in VET systems}

There is wide variation across countries in how VET programmes are organised and delivered, as well as the stages of education at which individuals pursue VET. One of the key distinctions between VET systems concerns the use of workplace learning. Generally, VET programmes are classified as school-based, work-based or combined school- and work-based, and often countries provide different types of programmes in parallel.

- In school-based programmes, at least $75 \%$ of the curriculum is presented in the school environment (this may include distance education). This includes special training centres run by public or private authorities, or enterprise-based special training centres if they qualify as educational institutions. In countries like Slovenia, Finland and Portugal, upper-secondary and post-secondary non-tertiary VET programmes are predominantly school-based.

- In combined school- and work-based programmes, at least $10 \%$ but less than $75 \%$ of the curriculum is presented in the school environment or through distance education, with the remainder organised as work-based learning. These programmes can be organised in conjunction with education authorities or institutions. They include apprenticeship programmes that involve concurrent school-based and work-based training (e.g. in Denmark and Norway), and programmes that involve alternating periods of attendance at educational institutions and participation in work-based training (like in the dual system in Germany and Switzerland).

- In work-based programmes, the school-based component makes up less than $10 \%$ of the time. Such programmes are usually non-formal education programmes leading to a qualification that is recognised by national education authorities (or equivalent).

(Flanders only) and the United Kingdom (England and Northern Ireland only). The EU member states not covered are Bulgaria, Croatia, Latvia, Luxembourg, Malta, Portugal, and Romania.

9 The United States is an exception, as they participated in the PIAAC survey in multiple years. A new cycle of the PIAAC survey will be carried out in 2021-2022, making it possible to compare countries at different points in time. Similar surveys have been carried out in the periods 1994-1998 (International Adult Literacy Survey) and 2003-2007 (Adult Literacy and Life Skills Survey), but differences in implementation and technical standards limit the comparability between those surveys and PIAAC. 
The quality of work placements in work-based and mixed systems is crucial. How work placements are regulated and organised determines whether students will systematically participate in quality-assured placements, which allow them to develop useful skills and connect with employers or whether work placements remain an optional add on and of limited value. A lack of comparative data on the design features of workplace learning limits the international comparability of VET programmes and makes it difficult to categorise different VET systems.

Another important aspect of VET is the involvement of social partners beyond the role of employers in providing workplace learning opportunities. Social partners can be involved in designing curricula, qualification standards and student evaluation guidelines. Moreover, social partners can share information about student outcomes and skill needs to feed into the re-design of curricula, and can be involved in determining the optimal timing for curriculum re-design. In countries like Austria, Switzerland, Denmark and Germany, social partner involvement in these aspects is strong.

It is important to note that not all OECD countries offer VET programmes at both the upper-secondary and post-secondary non-tertiary level. In the United States, for example, there is no distinctive vocational path at upper-secondary level, but vocational courses are offered (optionally) within the general track. VET is provided mainly at post-secondary level, with community colleges being the main provider. Similarly, in New Zealand students in upper-secondary education can integrate vocational courses in general programmes, but fully-fledged vocational programmes mostly exist at the post-secondary level. In Canada and Ireland, VET programmes are typically delivered at the postsecondary level (with Quebec being the exception in Canada). Also within the group of countries that have a substantial VET offer at the secondary education level, there are differences in terms of the age at which students are tracked into the different streams (i.e. VET versus general education).

Moreover, countries also differ in terms of the pathways available for VET graduates to enter higher education. Many OECD countries allow for direct access of VET graduates to higher education or access through a bridging programme. In EU countries, two thirds of VET students at the upper-secondary level are enrolled in programmes that give direct access to tertiary education (2017 data). However, internationally comparable data on progression from mid-level VET to higher education is limited, and hence little is known about the use of the different pathways.

Finally, there are many more aspects in which VET systems differ between countries, including the level of autonomy granted to VET providers, funding mechanisms, the availability and use of skills forecast mechanisms, and the availability and use of new technologies and modern equipment. Differences in VET graduates' outcomes need to be seen in light of these structural differences in VET systems.

Source: Kís (forthcoming[27]), KOF Swiss Economic Institute (2016[31]), Cedefop (2020[32]). 


\section{Chapter 3. The profile of vocational education graduates}

Countries differ in the way VET is organised and its importance in the overall education and training system. This translates into substantial differences with regards to the share of graduates with VET qualifications and their fields of specialisation, but also the characteristics and cognitive skills of VET graduates. This chapter explores these differences using European Labour Force Survey data and the Survey of Adult Skills.

\subsection{Graduates composition}

\subsubsection{A substantial share of graduates have a VET degree}

When looking at the types of qualifications held by individuals aged 15 to 34 , it is clear that VET plays a prominent role in most European countries (see Figure 3.2). On average, the highest education level of one out of three individuals aged 15 to $34(34 \%)$ is an upper secondary (ISCED-3) or post-secondary non-tertiary level (ISCED-4) qualification with vocational orientation. Moreover, $68 \%$ of those whose highest qualification is at ISCED-3 or ISCED-4 level have a vocationally oriented qualification. The reason for a relatively low share of general education graduates in most countries, is that most general education graduates continue into higher education, see Box 3.1 for details. Enrolment data show that in 2018, 48\% of students in upper secondary education (ISCED-3) in the EU-28 were in the vocational track. At the post-secondary non-tertiary level (ISCED-4), 91.5\% of all enrolments were in vocational programmes (2016 data). ${ }^{10}$

\section{Box 3.1. Continuing education and training after general programmes}

In many European countries, general programmes at ISCED levels 3 and 4 are designed to prepare students to continue education after graduation, and are therefore not intended to lead graduates directly to the labour market. Indeed, the majority of young people whose (current) highest qualification is a general programme are still studying $(61 \%)$, and only $32 \%$ are employed or unemployed, compared to $76 \%$ of VET graduates (see Panel A. of Figure 3.1). Moreover, general education graduates who did not continue education are substantially less likely than graduates from VET programmes at similar levels to mention "My education is enough" as the main reason for not continuing education (14\% compared to $32 \%$, Panel B). In fact, general education graduates' main activity and reason for not continuing further education are similar to those of individuals who did not complete at least an upper-secondary qualification.

These results highlight that general education graduates who enter the labour market are likely to be a very selective sample of youngsters who are not representative of the full population of general education participants. ${ }^{11}$ This needs to be taken into account when

\footnotetext{
${ }^{10}$ Data on enrolments are from Eurostat.

${ }^{11}$ Likewise, since the group of mid-level VET graduates only focuses on VET graduates who did not continue to higher education, it is a selective sample. However, this selection issue is much
} 
interpreting graduates' outcomes, such as their types of jobs and job quality. This is also why this paper not only compares VET graduates to graduates from general programmes at similar levels, but also to graduates from lower and higher levels of education.

Figure 3.1. T Main activity and reasons for not continuing education, by education

Panel A. Main activity

\section{EU-average}

Panel B. Reason for not having continued education

$\square$ Other reasons

口Health reasons

$\Delta$ Farnity reasons
ol wanted to work

$\square$ Costs of study would be too high

$\square$ Study did not fit needs or interests

aFailed entrance exam, or study would be too difficult

口 Highest level of education was considered high enough
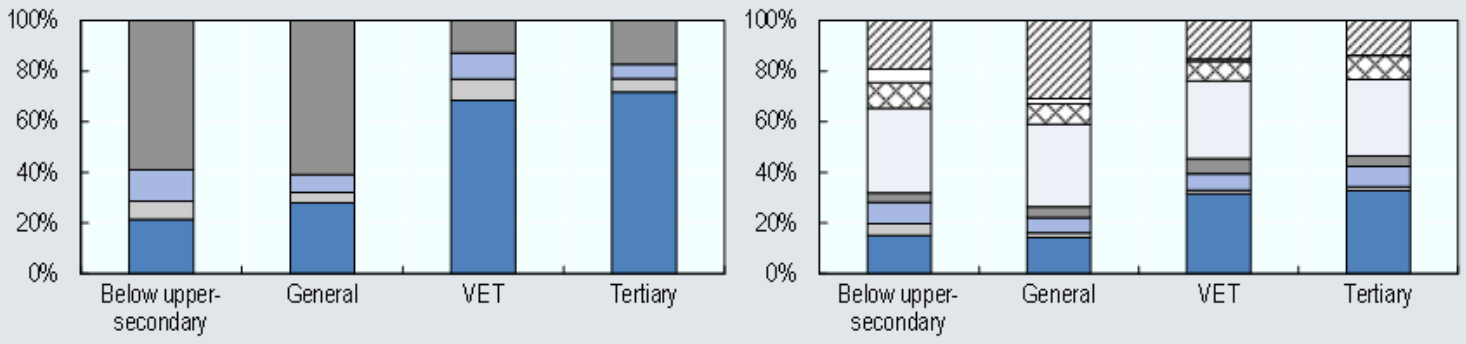

Note: Panel A includes individuals aged 15 to 34 . Panel B includes individuals aged 15 to 34 not in formal education. Note that if the continued education were completed successfully, the highest obtained degree would have been different. NEETs are those who are currently not in employment, education or training.

Source: Authors' calculations using EU-LFS (2016) and the EU-LFS ad-hoc module Young people on the labour market (2016).

In countries like Germany, the Slovak Republic, the Czech Republic or Croatia, almost everybody whose highest qualification is at ISCED-3 or ISCED-4 level has a VET degree (more than 95\% among 15-to-34 year-olds). In other countries, such as Spain, Norway or Portugal, VET graduates are less common (less than $25 \%$ of 15 -to-34 year-olds), but still constitute at least half of those who completed at most an upper-secondary or post-secondary non-tertiary degree. Yet, there are also countries where VET is not very common, neither in the full 15-to-34 year-old population, nor among those with at most upper-secondary non-tertiary degrees (e.g. Ireland, Cyprus or Malta: less than $15 \%$ of the 15-to-34 year-olds).

smaller for VET than for general education graduates, as much fewer VET graduates continue to

higher education (see Figure 3.1). 
Figure 3.2. Highest obtained qualification of 15-to-34 year olds

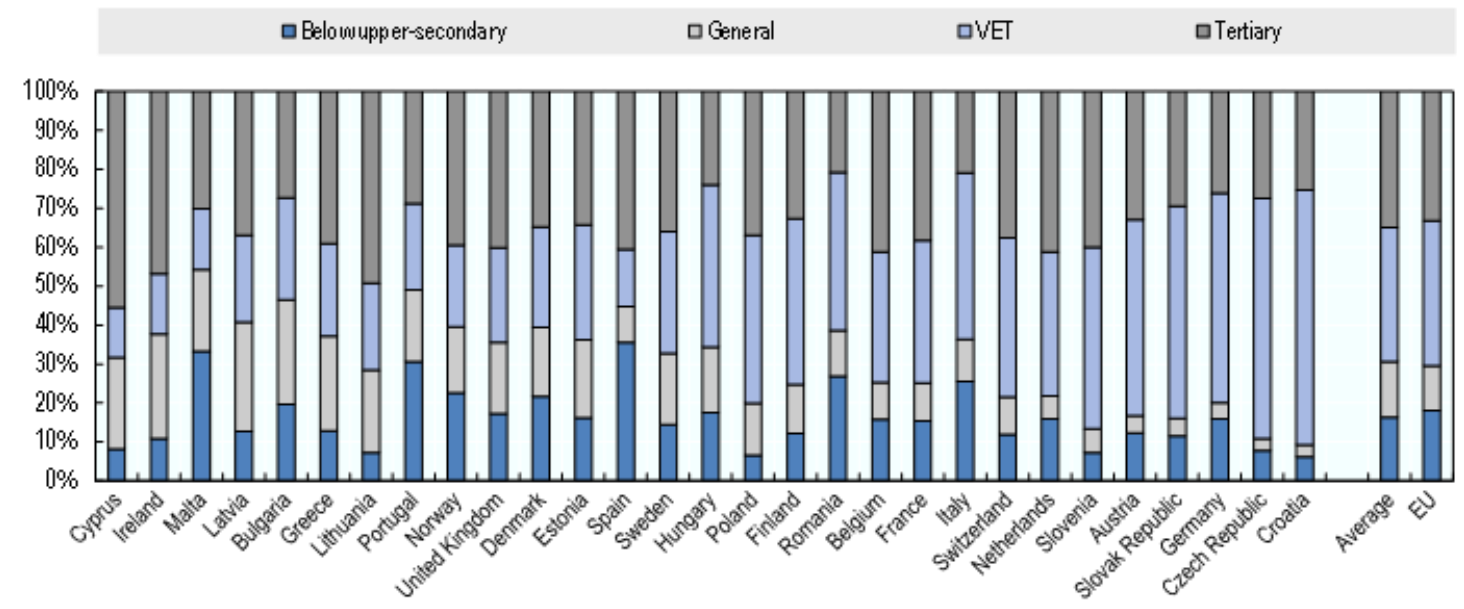

Note: Includes individuals aged 15 to 34 not in formal education. Data are sorted by the share of VET graduates among those with an upper-secondary non-tertiary degree. See Annex B for details on the calculation of the averages.

Source: Authors' calculations using EU-LFS data (2017).

In many European countries, work-based learning is a mandatory part of the VET curriculum. On average, $46 \%$ of European VET graduates had some work experience during their studies, and for most of them (68\%) this work experience consisted of a mandatory traineeship or apprenticeship (Figure 3.3). In comparison: one third (33\%) of general education graduates had some work experience during their studies, which consisted mostly of independent work experience outside of the curriculum. This could for example entail a part-time (side) job or volunteering. Although study-related work experience is generally more efficient for acquiring job-specific skills, any type of work exposure may help the student acquire transferable job skills such as taking initiative, problem solving and using information resources (Lasonen, 2005 [33]).

Figure 3.3. Type of work experience during highest level of education

EU-average

$\begin{array}{ll}\square \text { Apprenticeship (paid, mandatory, } \geq 6 \text { months) } & \square \text { Mandatory traineeship } \\ \square \text { Other mandatory work-based training } & \square \text { Optional traineeship (part of education) } \\ \square \text { Independent work experience (outside of education) } & \square \text { Nowork experience during studies }\end{array}$

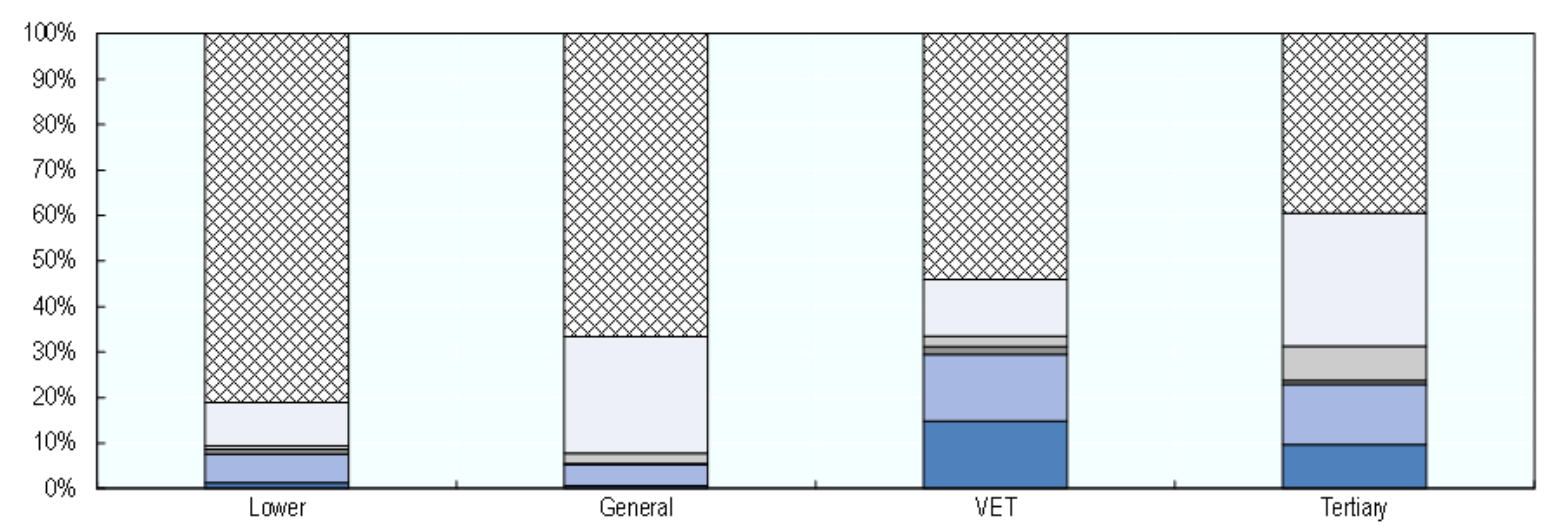

Note: Includes individuals aged 15 to 34 not in formal education. 
Source: Authors' calculations using EU-LFS ad-hoc module Young people on the labour market (2016).

\subsubsection{Technical subjects are most popular among VET graduates}

In most European countries, the most common field of study for VET graduates is 'Engineering, manufacturing and construction'. In some countries, particularly Switzerland, Germany, Italy, Austria and Denmark, 'Social sciences, business and law' programmes are also very popular among VET graduates. VET programmes in the field of 'Services' are particularly common in Latvia, Lithuania and Hungary. In some other countries, such as Ireland, the Netherlands, Malta, Portugal and the United Kingdom, there is not one particular field of study that is most popular among the VET graduates; VET graduates in these countries specialised in a variety of fields.

Figure 3.4. Fields of study of VET graduates

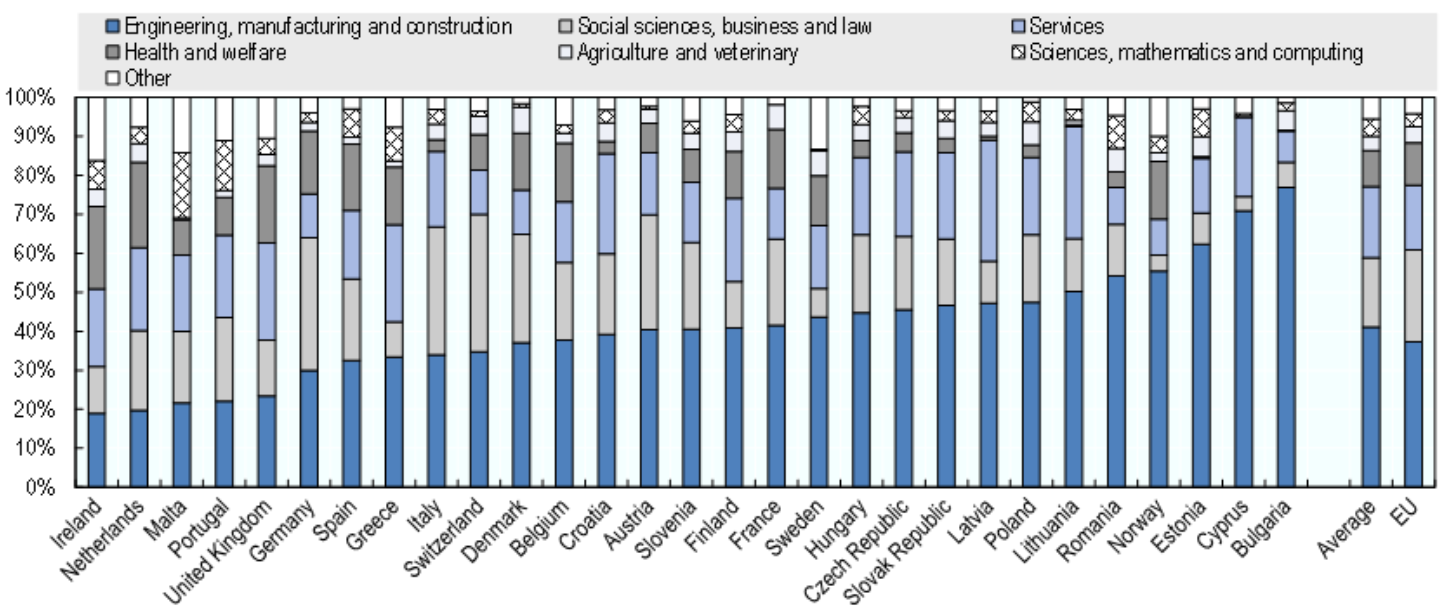

Note: Includes individuals aged 15 to 34 not in formal education. 'Other' fields of study include 'Humanities, language and arts', 'Teacher training and education science' and 'General VET programmes'.

Source: Authors' calculations using EU-LFS data (2017).

\subsection{Personal characteristics}

\subsubsection{Women are less likely to have a VET qualification}

In almost all European countries, the share of women is significantly lower among VET graduates than among those from general programmes at similar levels or from tertiary education (Figure 3.5). On average, $40 \%$ of VET graduates and graduates without at least an upper-secondary qualification are female, whereas the gender distribution among graduates from general programmes is $50 / 50$, and the majority $(58 \%)$ of tertiary education graduates is female. Exceptions are the United Kingdom, Germany, the Netherlands and Ireland, where the share of women is higher among VET graduates than among graduates from general programmes. 
Figure 3.5. Share of women among 15-to-34 year-olds, by education

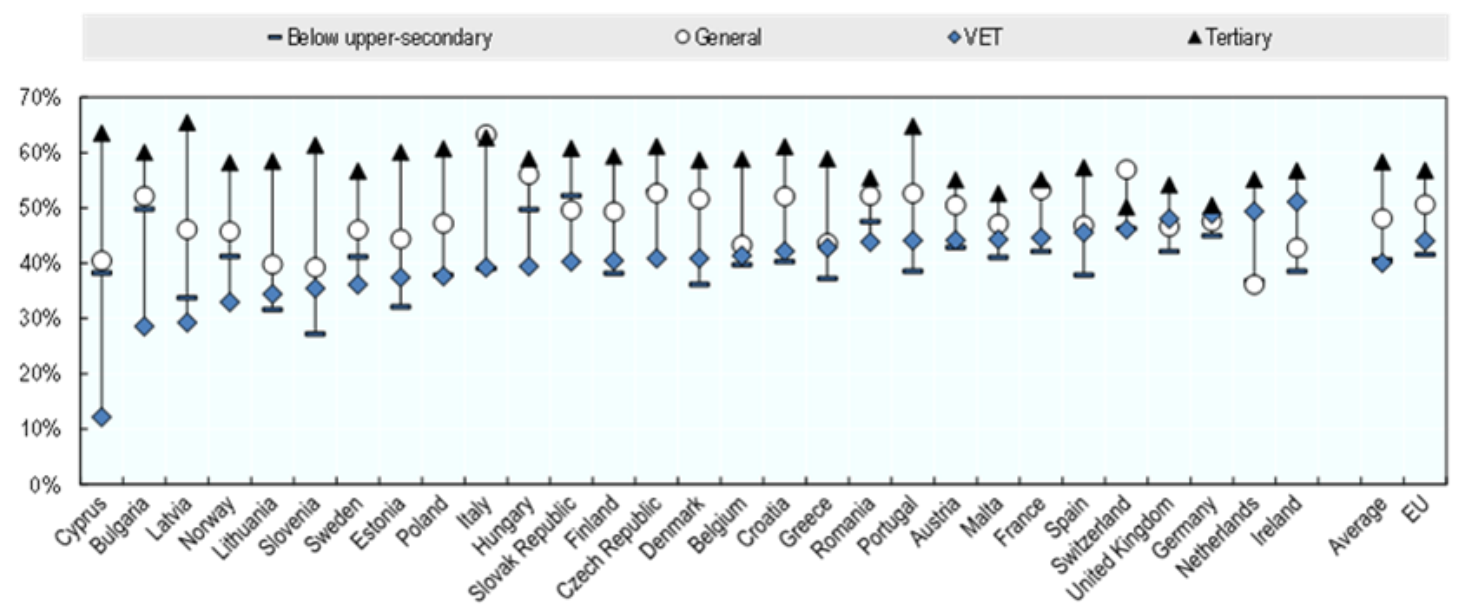

Note: Includes individuals aged 15 to 34 not in formal education.

Source: Authors' calculations using EU-LFS data (2017).

Significant gender differences also exist in terms of the specialisation of VET studies. Whereas male VET graduates are most likely to have studied 'Engineering, manufacturing and construction' (59\%), only $10 \%$ of the female VET graduates completed this field of study. The most common fields of study for female VET graduates are 'Social sciences, business and law' (35\%), 'Services' (23\%) and 'Health and welfare' (22\%) (Figure 3.6).

Figure 3.6. Fields of study of VET graduates, by gender

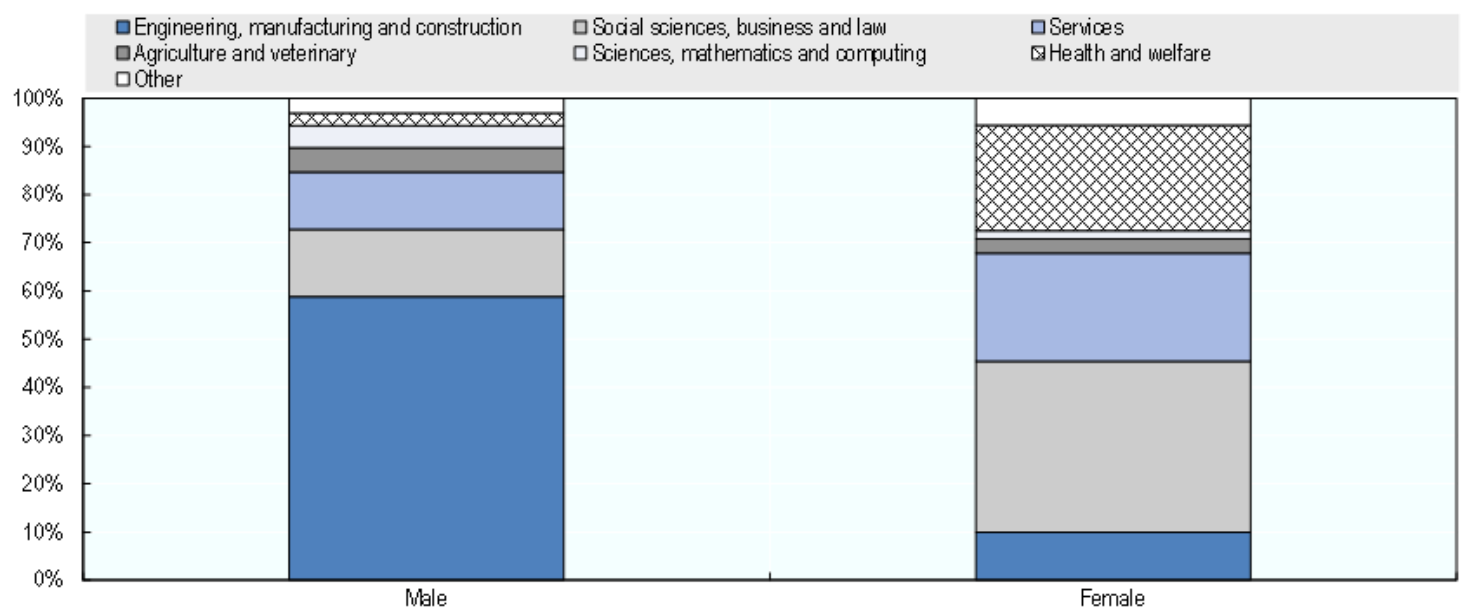

Note: Includes individuals aged 15 to 34 not in formal education. "Other" fields of study include "Humanities, language and arts", "Teacher training and education science" and "General VET programmes".

Source: Authors' calculations using EU-LFS data (2017).

Table 3.1 confirms that, compared to graduates from general programmes, VET graduates are more likely to be male, and also shows that they are more likely to have lower educated parents, and to have started a family. Their probability to be foreign-born is comparable to 
general education graduates. ${ }^{12}$ Compared to graduates from general programmes at upper-secondary level, or individuals without an upper-secondary qualification, VET graduates are significantly older. However, compared to graduates from tertiary education, they are significantly younger. To a large extent, this reflects the different times needed to complete the different educational programmes. However, cohort effects - i.e. a decreased likelihood of VET participation over time - may also play a role. Another possibility is that early school-leavers (i.e., youngsters who did not continue education or training after completing at most a lower-secondary programme) are more likely to re-enter education in a VET programme than in the general track of upper-secondary education. Due to the break in their educational career, former early school-leavers tend to be older than other students.

Table 3.1. Determinants of VET status in 2017

Marginal effects after logistic regression

\begin{tabular}{|c|c|c|c|}
\hline & $(1)$ & (2) & (3) \\
\hline & $\begin{array}{l}\text { VET vs. Below } \\
\text { upper-secondary }\end{array}$ & VET vs. General & VET vs. Tertiary \\
\hline \multirow[t]{2}{*}{ Gender ( 1 = female $)$} & $0.033^{* \star *}$ & $-0.056^{* * *}$ & $-0.130^{* \star *}$ \\
\hline & $(0.003)$ & $(0.004)$ & $(0.013)$ \\
\hline \multicolumn{4}{|l|}{ Parents' highest obtained qualification } \\
\hline Below upper-secondary & Ref. & Ref. & Ref. \\
\hline \multirow[t]{2}{*}{ Upper secondary } & $0.190^{* \star *}$ & $-0.030^{* * *}$ & $-0.095^{\star * *}$ \\
\hline & $(0.016)$ & $(0.010)$ & $(0.010)$ \\
\hline \multirow[t]{2}{*}{ Tertiary } & $0.190^{* * *}$ & $-0.160^{* * *}$ & $-0.371^{* * *}$ \\
\hline & $(0.008)$ & $(0.009)$ & $(0.014)$ \\
\hline \multirow[t]{2}{*}{$1^{\text {st }}$ generation immigrant in current country of residence $(1=$ yes $)$} & $-0.104^{\star \star \star}$ & -0.013 & $-0.017^{*}$ \\
\hline & $(0.013)$ & $(0.015)$ & $(0.009)$ \\
\hline \multicolumn{4}{|l|}{ Age } \\
\hline \multirow[t]{2}{*}{ 15-19 years old } & $-0.277^{\star \star \star}$ & $-0.147^{\star * \star}$ & $0.226^{\star \star \star}$ \\
\hline & $(0.015)$ & $(0.014)$ & $(0.007)$ \\
\hline 20-24 years old & Ref. & Ref. & Ref. \\
\hline \multirow[t]{2}{*}{$25-29$ years old } & $0.029^{* * *}$ & $0.025^{\star \star *}$ & $-0.200^{\star * *}$ \\
\hline & $(0.004)$ & $(0.004)$ & $(0.016)$ \\
\hline \multirow[t]{2}{*}{ 30-34 years old } & $0.036^{\star \star *}$ & $0.025^{\star \star \star}$ & $-0.273^{\star \star \star}$ \\
\hline & $(0.006)$ & $(0.008)$ & $(0.010)$ \\
\hline \multicolumn{4}{|l|}{ Children } \\
\hline No own children & Ref. & Ref. & Ref. \\
\hline \multirow[t]{2}{*}{ One child } & $-0.051^{* * *}$ & $0.031^{\star * *}$ & $0.143^{* * *}$ \\
\hline & $(0.004)$ & $(0.007)$ & $(0.010)$ \\
\hline \multirow[t]{2}{*}{ Two children or more } & $-0.132^{* * *}$ & $0.050^{* \star *}$ & $0.234^{* * *}$ \\
\hline & $(0.012)$ & $(0.008)$ & $(0.015)$ \\
\hline Observations & 263592 & 243422 & 327347 \\
\hline
\end{tabular}

12 Note that, in this paper, graduates who obtained their degree in another country than the country of residence at the time of the survey are excluded from the analyses. That means that foreign-born individuals must have moved to their current country of residence before they obtained their highest level of education. 
Note: Results of three logistic regression analyses. Includes individuals aged 15 to 34 not in formal education. The dependent variable is an indicator variable with value 1 if a person's highest obtained qualification is upper secondary VET, and 0 if the highest obtained qualification is below upper-secondary level (column 1), a general programme (column 2), or a tertiary qualification (column 3 ). The regressions include fixed effects for the region of residence one year prior to the survey, as well as for missing values on the explanatory variables. Robust standard errors, clustered at the regional level one year prior to the survey, are reported in parentheses, $* * * \mathrm{p}<0.01, * * \mathrm{p}<0.05, * \mathrm{p}<0.1$.

Source: Authors' calculations using EU-LFS data (2017).

\subsubsection{VET graduates have lower proficiency in cognitive skills than general education graduates on average}

PIAAC data show that graduates aged 16 to 34 from different education groups differ strongly in terms of their proficiency in numeracy, literacy and problem-solving in technology-rich environments (Figure 3.7). In the large majority of countries, literacy and numeracy proficiency of VET graduates is lower than that of graduates from general education and tertiary education, but higher than that of graduates without an upper secondary degree. Only in the United States, Canada, Japan and New Zealand are VET graduates slightly more proficient in numeracy and literacy than their general education counterparts. Similarly, VET graduates have lower digital problem-solving skills than general education graduates, and this difference is slightly larger than for literacy and numeracy. These cognitive skill proficiency differences are in line with the differences observed among 15-year olds in the PISA test, see Box 3.2. Differences in PIAAC scores are not surprising given the different scope of VET and general education programmes. However, some countries have managed to keep the gap relatively small (e.g. Norway), while in others the gap is substantial (e.g. Netherlands). 
Figure 3.7. Literacy, numeracy and problem-solving proficiency of graduates, by education Average proficiency (500-point scale)
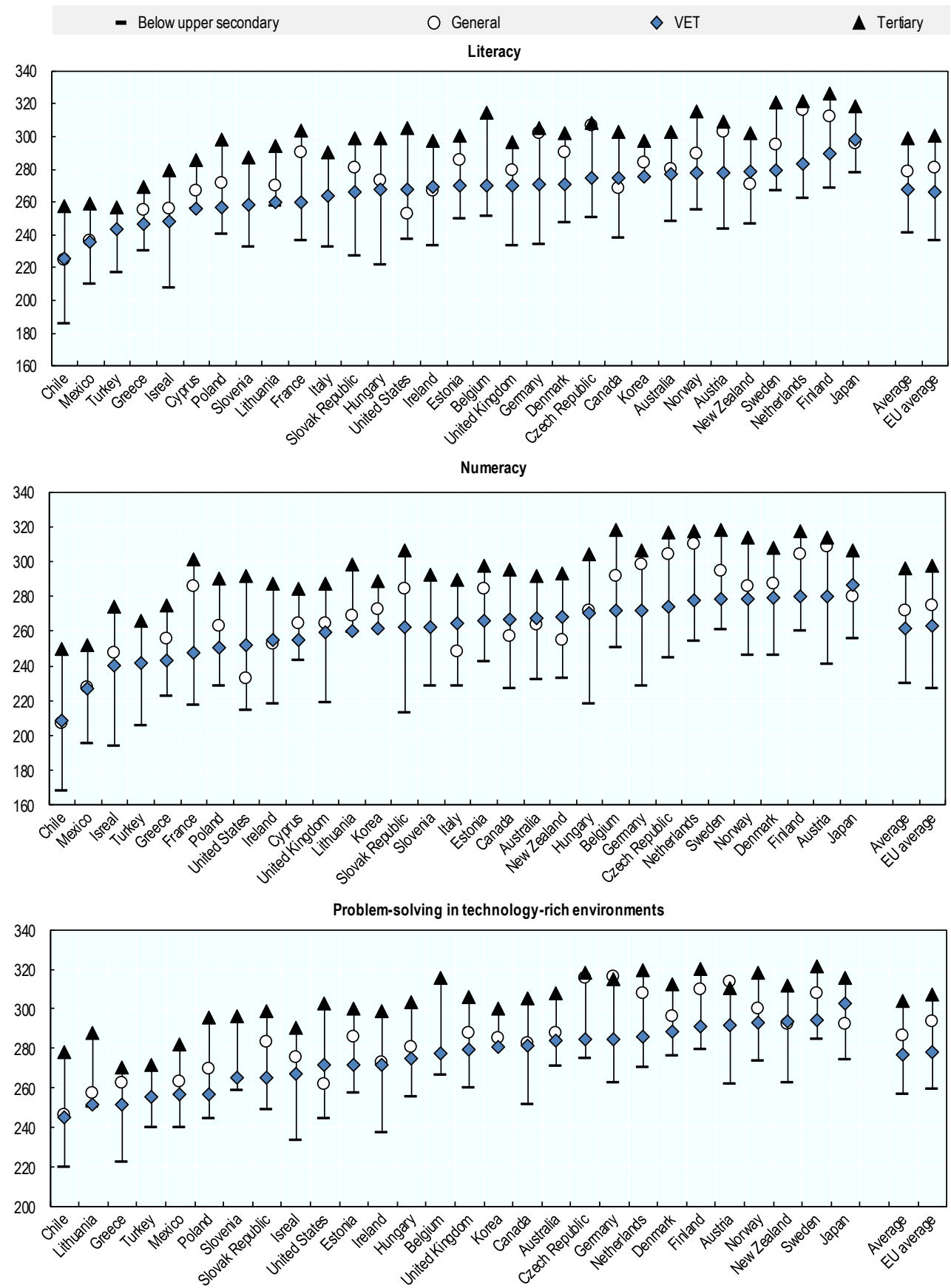

Note: Includes individuals aged 16 to 34 not in formal education. Belgium refers to Flanders only, the United Kingdom to England and Northern Ireland.

Source: Authors' calculations using the Survey of Adult Skills (2012, 2014, 2017). 


\section{Box 3.2. Student performance in key subjects}

The OECD's PISA data, which assess 15 year-olds performance in reading, mathematics and science, allow comparing skill levels of students in vocational and general programmes at the secondary education level. As PISA data refer to 15-year old students, and in many countries the main vocational programmes starts at a later stage, the results only cover a very specific part of the vocational students. ${ }^{13}$ Moreover, at age 15 students, even if they are in a vocational track, have typically spent very little time in such targeted occupational training. Therefore, poorer performance might predominantly reflect selection effects and could potentially highlight issues in the initial education years to develop crucial foundational skills.

Figure 3.8 shows that the share of low performers in mathematics is twice as large among students enrolled in a vocational track than among students in a general track. On average across OECD countries, $41 \%$ of students enrolled in a vocational programme were low performers in mathematics in 2012 , whereas $21 \%$ of students in a general track were. The difference in the share of low performers between vocational and general education students is larger than 40 percentage points in Greece, Hungary, Ireland, Israel, the Netherlands and Spain. Only in a handful of countries (Colombia, Mexico and Switzerland), the share of low performers is larger among students in general education programmes.

Figure 3.8. Percentage of low performers in mathematics, by programme orientation

Percentage of 15-year old students (2012)

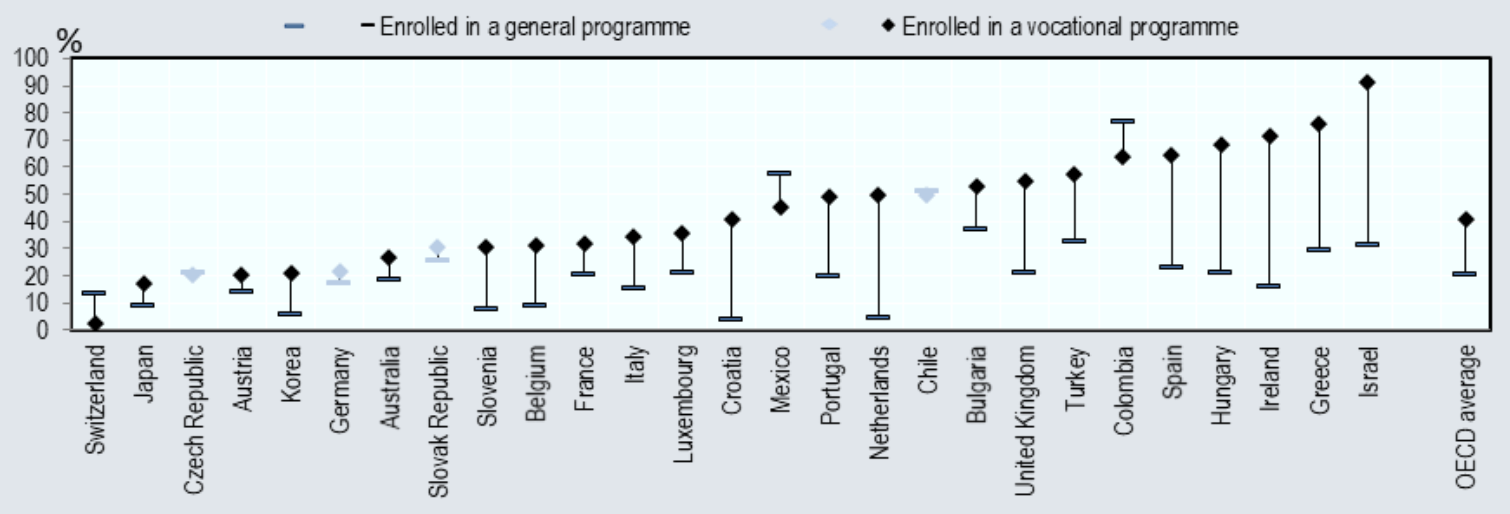

Note: Statistically insignificant percentage-point differences between the share of low-performing students who are enrolled in VET programmes and those who are enrolled in general education programmes are marked in a lighter tone. Students enrolled in VET programmes are those enrolled in pre-vocational, vocational and modular programmes.

Source: OECD (2016[34]).

${ }^{13}$ It is important to note that in many countries some of the vocational tracks are only available for students older than 15 years old. The PISA sample therefore does not reflect the full range of vocational programmes. According to 2015 PISA data, $82 \%$ of students in OECD countries were in enrolled in general programmes. In 15 OECD countries, more than $99 \%$ of 15 -year old students were enrolled in general programmes (OECD, 2016 $\left.6_{[106]}\right)$. 
When looking at the share of graduates who have low skill levels (i.e. at or below level 1 in PIAAC), Figure 3.9 shows that VET graduates are more likely to have low literacy, numeracy and/or digital problem-solving skills in most countries, compared to graduates from general education. On average across PIAAC countries, $15.7 \%$ of VET graduates have low literacy skills, compared to $11.9 \%$ of general education graduates. $20.9 \%$ of VET graduates have low numeracy skills, compared to $17 \%$ of general education graduates. Finally, $21.9 \%$ of VET graduates have low problem-solving skills, compared to $16.1 \%$ of general education graduates. Gaps in digital problem-solving skills are much more outspoken in some countries than they are for numeracy and literacy skills (e.g. Poland, Slovenia, Slovakia, Lithuania, Korea and Japan). While in most countries VET graduates have slightly lower cognitive skill levels then general education graduates, some countries still manage to have a very small share of VET graduates scoring at the lowest level of the PIAAC test (e.g. Austria, Finland and the Netherlands). The difference between VET and general education graduates remains significant also after controlling for personal characteristics (i.e. gender, age, migrant status, number of children), except for literacy proficiency. In most countries, the skills of VET graduates are substantially higher than the skills of those who left education without an upper secondary education degree. On the other hand, VET graduates and general education graduates have significantly lower skills than tertiary education graduates.

The lower skill levels of VET graduates compared to general and tertiary education graduates suggest that these graduates might have more difficulty in adapting to changes, either when having to move into other occupations and/or participate in further education and training.

\subsection{Conclusion}

In most European countries, VET is an important component of the overall education and training system. On average, two thirds of middle-educated adults (i.e. completed at least upper secondary education but no tertiary education) aged younger than 35 who are no longer in education, have a VET degree. However, differences between countries are large. The largest group of VET graduates are specialised in technical fields (i.e. engineering, manufacturing and construction), but social sciences, business and law, as well as services, are also popular fields for VET graduates. Gender differences are substantial, with women being less likely to have a VET degree in most countries, and those who have a VET degree specialising in different fields than men.

Compared to general education graduates, VET graduates are more likely to have children, and less likely to have parents with at least upper secondary education. When comparing graduates in terms of cognitive skill levels, VET graduates have lower scores than general education graduates in literacy, numeracy and digital problem-solving. The latter could imply that VET graduates have lower adaptability in today's changing labour market. In countries like Norway, Sweden, Japan and New Zealand, VET graduates have relatively high levels of skills, both relative to VET graduates in other countries and relative to general education graduates in their own country. In these countries, VET graduates might face less difficulties adapting to changes. 
Figure 3.9. Share of graduates with low literacy, numeracy or problem-solving proficiency, by education
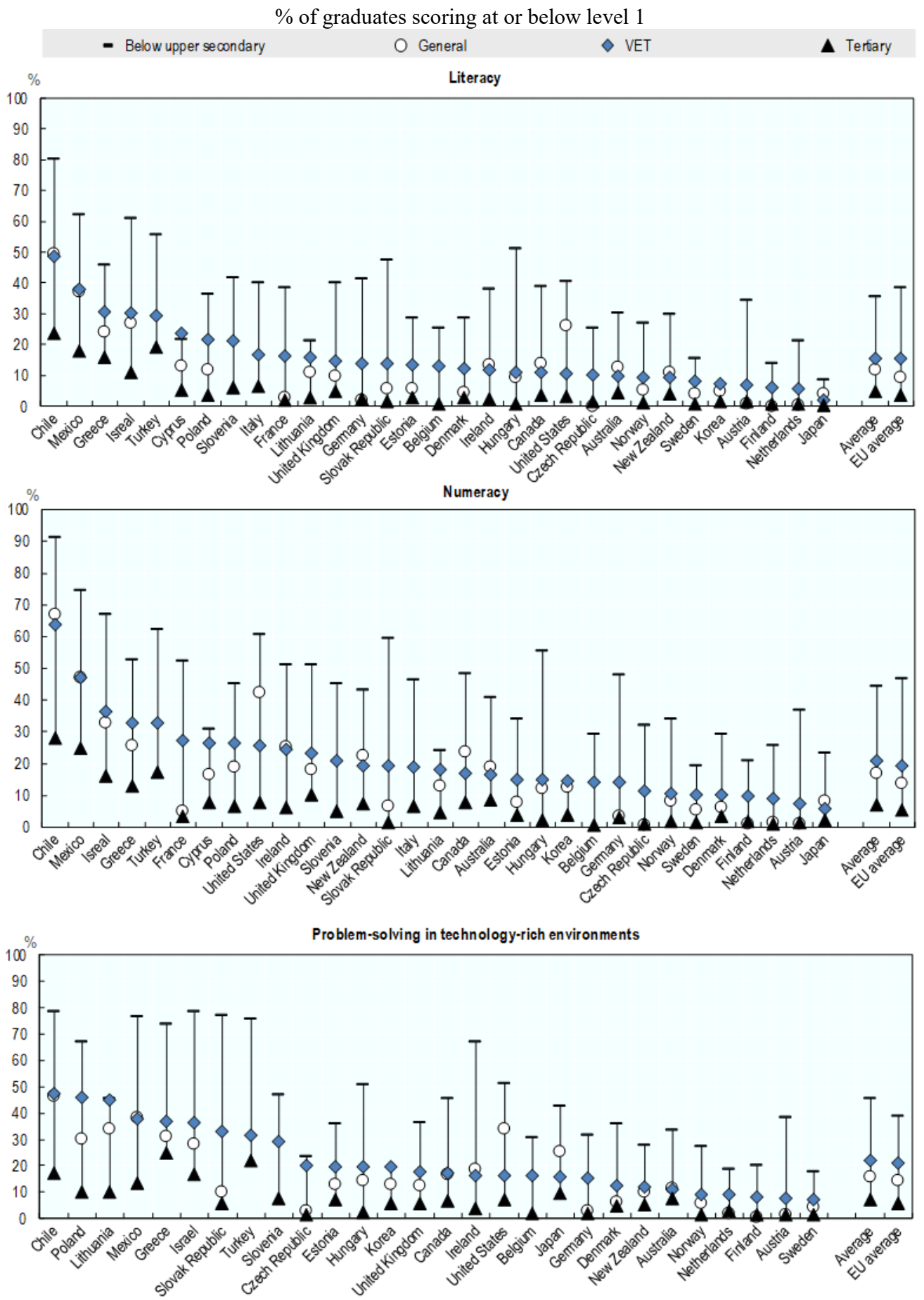

Note: Includes individuals aged 16 to 34 not in formal education. Belgium refers to Flanders only, the United Kingdom to England and Northern Ireland. At or below level 1 in problem-solving includes adults with no computer experience and adults who failed the ICT core test.

Source: Authors' calculations using the Survey of Adult Skills (2012, 2014, 2017) 


\section{Chapter 4. Labour market outcomes of vocational education graduates}

One of the key functions of VET is to directly prepare students for the labour market. This chapter explores the labour market outcomes of VET graduates compared to graduates from general education (upper secondary and post-secondary non-tertiary), as well as graduates from tertiary education and those without an upper secondary education degree. Outcomes are analysed not only from a quantity perspective, but also by looking at different aspects of job quality and the types of jobs held by the different graduates.

\subsection{Job quantity}

\subsubsection{VET graduates have higher employment rates than graduates from general education}

It is generally argued that one of the main benefits of VET is that it directly prepares students for the labour market, as such making their labour market entry easier. Research indeed suggests that VET graduates are more likely to find employment than graduates from general education, at least in the first years after graduation (Forster, Bol and van de Werfhorst, 2016 $6_{[17]}$; Hanushek et al., 2017 $7_{[18]}$; Brunello and Rocco, 2017 $\left.7_{[16]}\right)$. Figure 4.1 (Panel A) shows that employment rates are higher among VET graduates than among graduates from general programmes at similar levels (except in Portugal and the Czech Republic) and among those without an upper-secondary degree. At the same time, while the probability to be employed is high for VET graduates, it is lower than for the tertiary educated (except in the Slovak Republic, Malta and Iceland). The differences in employment rates between education groups persist when comparing graduates with similar personal characteristics ${ }^{14}$. Consistent with findings from earlier research, Box 4.1 shows that these differences in employment rates are smaller for older age groups.

Similarly, VET graduates are less likely to be unemployed than graduates from general education (except in Greece, Spain and Portugal; see Figure 4.1, Panel B). This difference is small in many countries, and it disappears when controlling for personal characteristics. VET graduates' unemployment rates are higher than among graduates from tertiary programmes (except in Denmark), and significantly lower than for graduates without an upper-secondary degree. These differences persist when comparing graduates with similar personal characteristics.

\footnotetext{
${ }^{14}$ Personal characteristics included in the regression analysis are gender, age, country of birth (foreign-born or not), number of own children, highest educational qualification of the parents, and region of residence. A similar regression using PIAAC data and including literacy and numeracy proficiency yields the same results.
} 
Figure 4.1. Share of individuals currently in (un)employment, by education
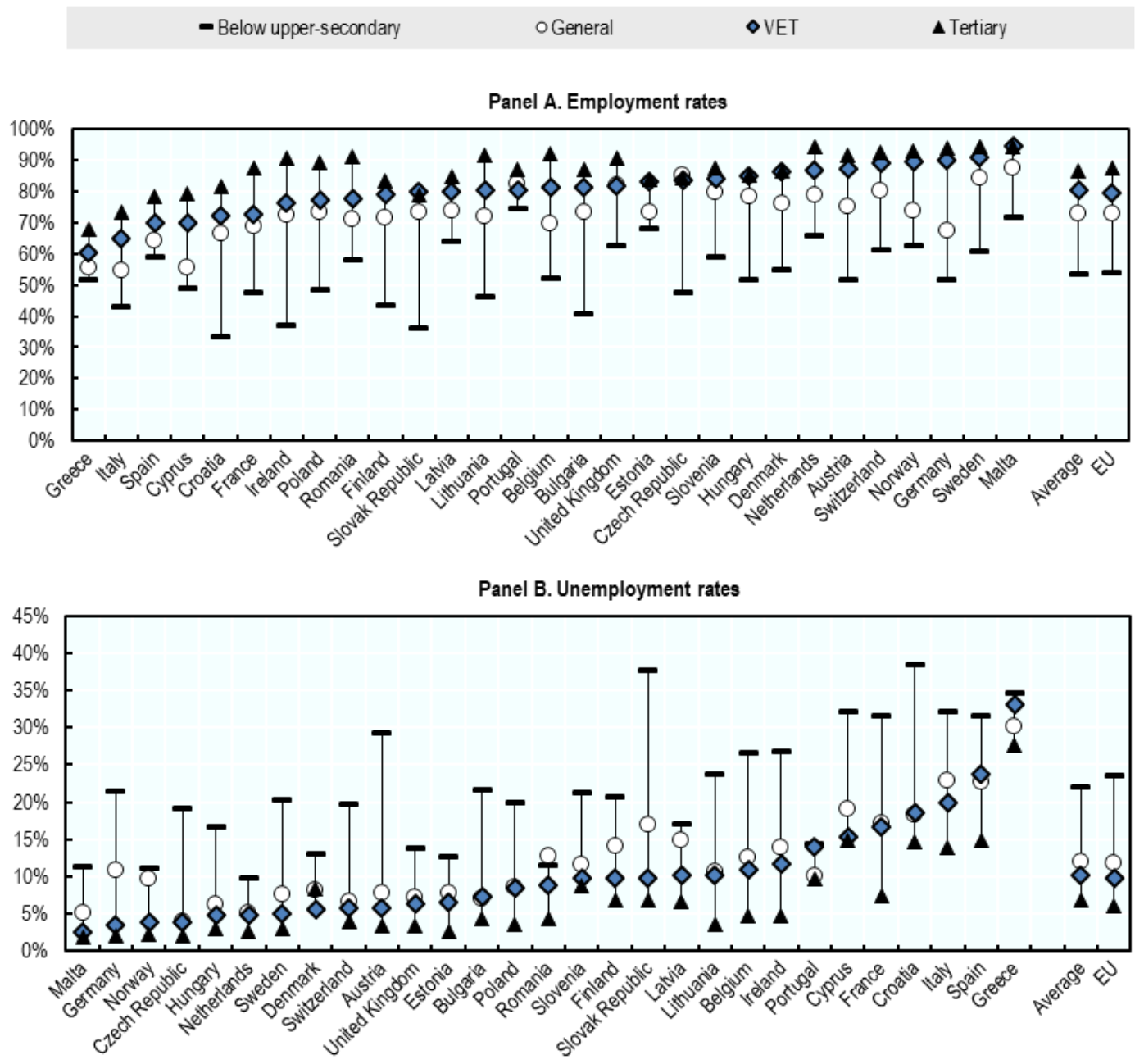

Note: Panel A includes individuals aged 16 to 34 not in formal education. Panel B includes employed and unemployed individuals aged 15 to 34 not in education or training.

Source: Authors' calculations using EU-LFS data (2017).

Figure 4.2 shows that unemployed VET graduates are slightly more likely to be unemployed for more than one year than general education graduates are (particularly in Denmark, Slovak Republic, France, Estonia, Finland and the Netherlands). In other words, while VET graduates are less likely than general education graduates to become unemployed, those who do not have a job take more time to (re-)enter employment. However, the difference between VET graduates and general education graduates in their probability to be long-term unemployed is not statistically significant once personal characteristics are taken into account. ${ }^{15}$ Compared to graduates from tertiary education, unemployment rates for VET graduates are not only higher, but those who are unemployed are also more likely to be long-term unemployed (except in Cyprus). Graduates without at

15 Personal characteristics included in the regression analysis are gender, age, country of birth (foreign-born or not), number of own children, highest educational qualification of the parents, and region of residence. 
least an upper-secondary degree have the worst employment outcomes: they are substantially more likely to be unemployed than graduates from any other education group, and the unemployed are most likely to be long-term unemployed (except in Denmark, Cyprus, Lithuania and Romania). On average, more than one third of the currently unemployed VET graduates (35\%) have been unemployed for one year or more, compared to $32 \%$ among unemployed graduates from general education programmes, $44 \%$ among unemployed individuals without an upper-secondary degree, and one fourth $(25 \%)$ among the unemployed graduates from tertiary education. The difference in long-term unemployment between VET graduates and those without an upper-secondary qualification and those with a tertiary qualification remain statistically significant once personal characteristics are taken into account.

Figure 4.2. Long-term unemployment rates, by education

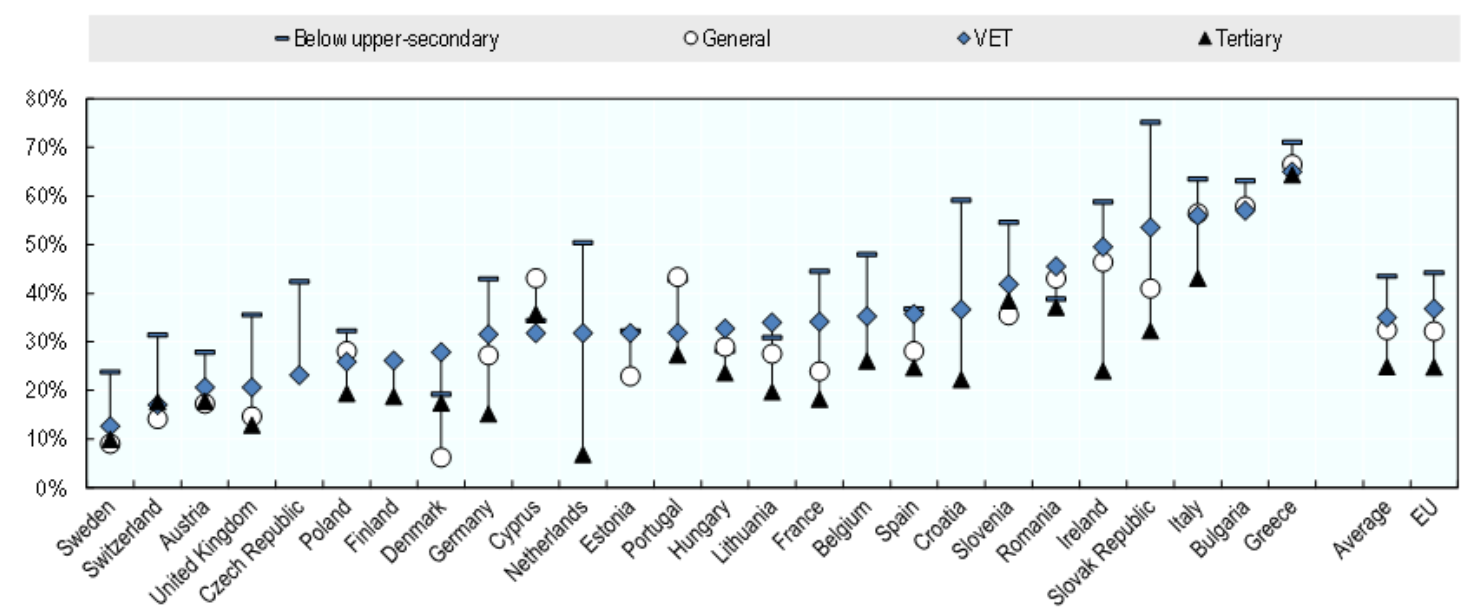

Note: Includes unemployed individuals aged 15 to 34 not informal education.

Source: Authors' calculations using EU-LFS data (2017).

\section{Box 4.1. Comparing graduates' employment rates to older age groups}

In contrast to the EU-LFS, the OECD Survey of Adult Skills (PIAAC) also contains information about the orientation of the highest qualification for individuals aged 35 and above. Figure 4.3 uses this information to compare employment rates of different age groups according to the level and orientation of their highest qualification.

Adults with a VET degree at the upper-secondary or post-secondary non-tertiary level have higher employment rates than general education graduates for the two youngest age groups. The employment rates of adults aged 45 or older with VET and general education degrees are almost identical. Similarly, the unemployment rate of VET graduates (aged 16 to 34 ) is lower than that of general education graduates, while adults aged 35 or older with vocational qualifications have unemployment rates equal to or higher than those of adults with general education qualifications in the same age groups. This might imply that, as they get older, vocational education graduates gradually loose (part of) their advantage on the labour market compared to general education graduates. The gap between adults with tertiary and vocational qualifications remains large in all age groups, 
as does the gap between those with a VET degree and those without an upper secondary degree.

When comparing graduates with similar numeracy proficiency and other personal characteristics (gender, number of children migrant status), the employment and unemployment rates of VET graduates relative to general education graduates stays broadly the same. Adding these controls reduces the gap between tertiary education graduates and VET graduates, although it remains significant in all age groups (except for unemployment rates among 55-65 year olds). It also reduces the gap between those without an upper secondary degree and VET graduates, but mainly for unemployment. The employment rate of adults without upper secondary education remains significantly lower than that of other graduates at all ages, even when they have similar skill levels and other personal characteristics.

Figure 4.3. Employment and unemployment rates, by age and education Percentage (PIAAC average)

- Below upper secondary Employment rate

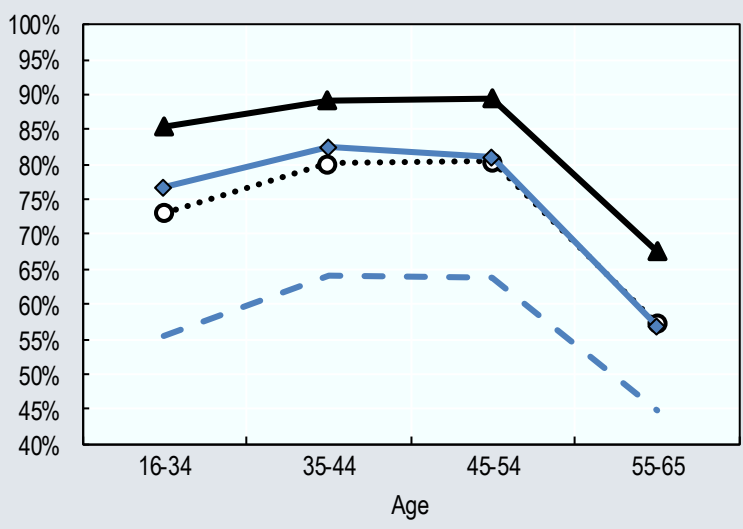

General

$\diamond$ VET

Unemployment rate

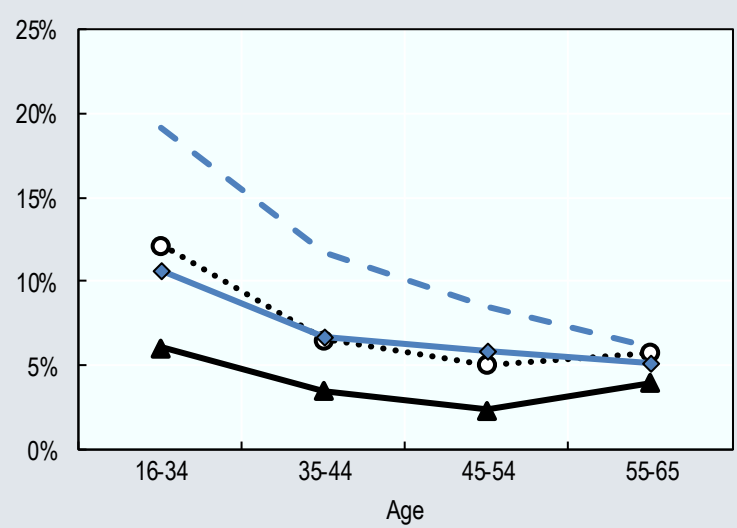

Note: Unweighted average of PIAAC countries with at least 50 observations. Excludes adults who are in formal education.

Source: Authors' calculations using the OECD Survey of Adult Skills (2012/14/17).

It is important to note that these differences between age groups also reflect structural changes in the education system. A VET degree of someone who graduated many years ago might look very different from a VET degree obtained recently. Moreover, changes in educational attainment might imply that the value of a certain degree today might be lower than it was in the past.

\subsubsection{VET graduates are more often not in employment, education or training than graduates from general education}

Those who are not employed, but also not in education or training are called NEETs. This group includes not only those who have not managed to find a job (unemployed NEETs), but also those who are not actively seeking employment and/or are not available for work (inactive NEETs), provided they are not enrolled in education or in a training programme. Young people who are neither in employment nor in education or training are at risk of 
becoming socially excluded - individuals with income below the poverty line and lacking the skills to improve their economic situation (OECD, 2006 [35]).

Panel A in Figure 4.4 shows that, on average in European countries, the share of NEETs aged 15 to 34 is higher among VET graduates (17\%) than among graduates from general education (11\%). Given that NEET rates are calculated including those who are still in education and a large group of 15 to 34 year olds with at most an upper-secondary or post-secondary non-tertiary degree with a general orientation are still in education, this contributes to a relatively low share of NEETs among general education graduates. VET graduates are particularly likely to be NEET in Greece, Italy, Croatia, France, Poland and Ireland, where more than one in five VET graduates are NEET, which is more than in any of the other education groups. In Scandinavian countries, Austria, Switzerland, Germany and the Netherlands, on the other hand, less than $10 \%$ of VET graduates are NEET.

Figure 4.4. Individuals not in employment, education or training (NEETs), by education
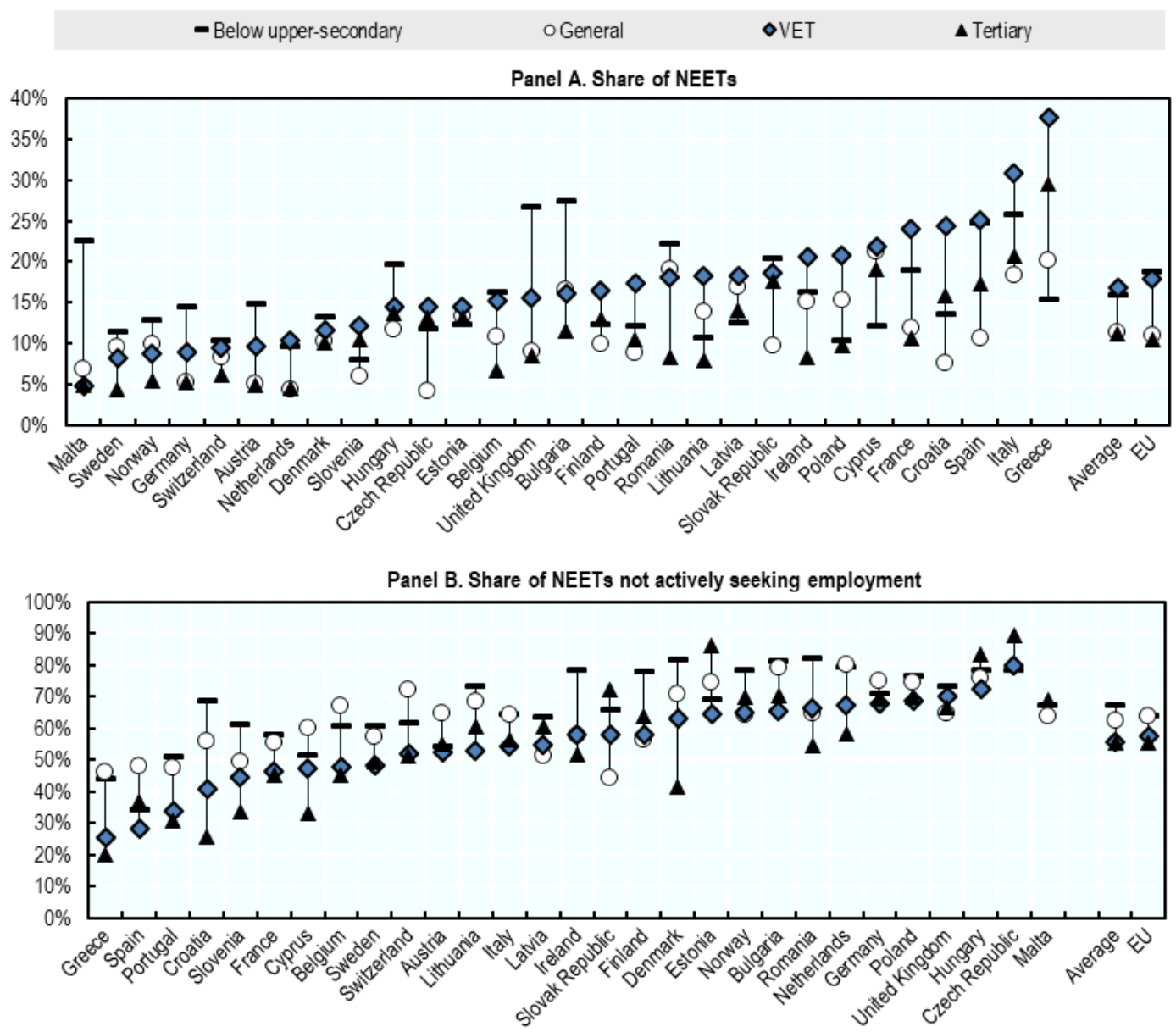

Note: Panel A includes all individuals aged 15 to 34. Panel B includes only individuals aged 15 to 34 who are not in employment, education or training (NEETs).

Source: Authors' calculations using EU-LFS data (2017).

On average across European countries, the majority of NEETs in all education groups are inactive (see Figure 4.4, Panel B). The average share of inactivity among NEETs with a VET degree is similar to those with tertiary education (55\%), but lower than among those 
from general programmes (63\%) or without an upper-secondary degree (67\%). This means that, on average, NEETs with a VET or tertiary degree are more likely to be available and actively looking for work than those with general education. There are, however, notable differences across countries. For example, in countries such as Greece, Spain, Portugal, Croatia, Slovenia, Belgium and Switzerland, NEETs with a VET degree are substantially less likely to be inactive than those with a general education qualification, whereas the reverse is true in countries such as the Slovak Republic, the United Kingdom or Latvia.

\subsubsection{VET graduates have higher work intensity than general education graduates}

Not only the probability of being in employment matters, but also the intensity of work. Fernandez et al. $\left(2016_{[36]}\right)$ define work intensity as the percentage of potential working time $^{16}$ in a twelve month period spent in employment, accounting for periods out of employment as well as lower than full-time working hours. The definition is in line with Eurostat's methodology for deriving the Europe 2020 indicator "household work intensity" (Eurostat, 2018 $\left.{ }_{[37]}\right)$. Work intensity can range from zero (i.e. no work activity in the analysed 12 -month period) to $100 \%$ (i.e. working full-time in the entire 12-month period).

Among graduates who have some work activity in the past 12 months, VET graduates are less likely to have low work intensity than general education graduates. $2.4 \%$ of VET graduates have very low work intensity (i.e. working less than $20 \%$ of their potential) and an additional $5.3 \%$ have low intensity (i.e. working between $20 \%$ and $45 \%$ of their potential), compared to $2.4 \%$ and $7.1 \%$, respectively, for general education graduates (Figure 4.5, Panel A).

In the large majority of countries, low work intensity is most common among graduates without an upper secondary education degree and least common among tertiary education graduates (Figure 4.5, Panel B). VET and general education graduates have a similar probability of having low work intensity in most countries. Only in the Netherlands, United Kingdom, Portugal, Lithuania, Greece, Spain and Cyprus VET graduates have a slightly higher probability of having low work intensity than graduates from general education. Similarly, in some exceptional cases, tertiary education graduates have higher probability of low work intensity than VET graduates (i.e. in the Czech Republic, Slovak Republic and Denmark). In all countries, VET graduates are less likely to have low work intensity than those without an upper secondary education degree.

\footnotetext{
${ }^{16}$ Potential working time is defined as full-time work during the entire 12 -month period.
} 
Figure 4.5. Work intensity of graduates

Percentage of graduates with some work activity in the last 12 months

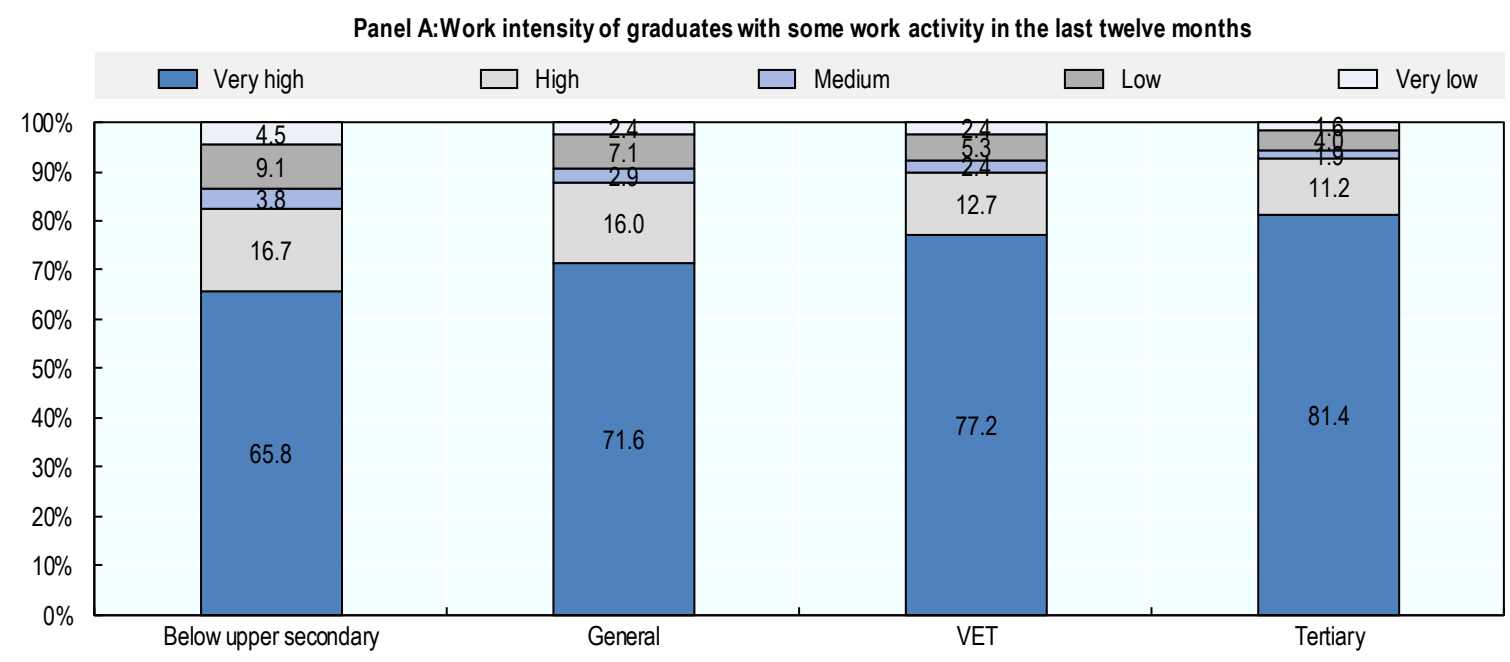

Panel B: Share of graduates with low or very low work intensity

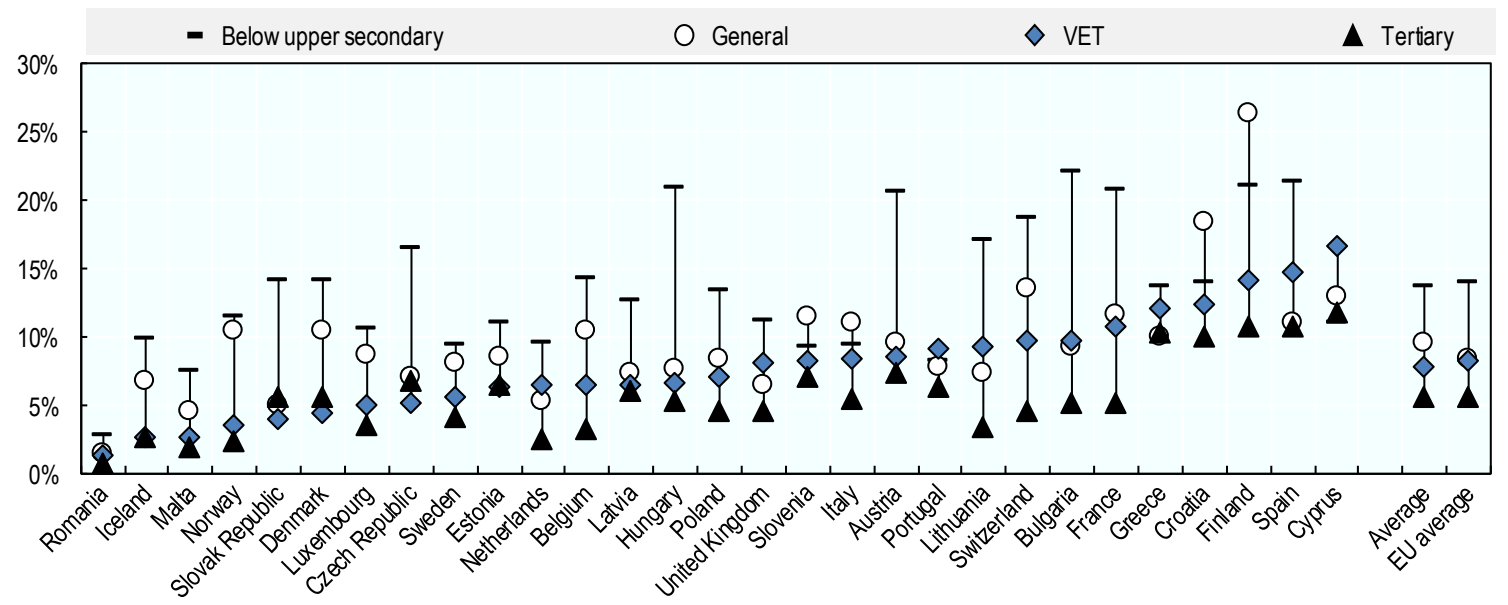

Note: Panel B refers to the unweighted average of EU-SILC countries. Includes individuals aged 15 to 34. Individuals who spent six months or more of the income reference period studying are excluded from the sample (in addition to those studying at the time of the interview). Intensity categories are defined as 1-19\% very low, $20-44 \%$ low, $45-54 \%$ medium, $55-84 \%$ high, and $85-100 \%$ very high. Graduates without work activity are excluded.

Source: Authors' calculations using EU-SILC data (2017).

On average across European countries, graduates from all education groups work approximately 38 hours per week. Although there are some differences across countries in the average number of hours worked, the difference between education groups remains fairly small. However, VET graduates are less likely to work part-time (13\%) than graduates from general programmes at similar levels (17\%) (Figure 4.6, Panel A). This difference remains when comparing VET and general education graduates with similar jobs and personal characteristics. ${ }^{17}$ Graduates without an upper-secondary degree are most

${ }^{17}$ Based on a regression analysis including occupation (2-digit ISCO), gender, age, country of birth (foreign-born or not), number of own children, highest educational qualification of the parents, and current region of residence. 
likely to work part-time (20\%), and those from tertiary education are least likely to work part-time (11\%). Although the difference in part-time employment between VET and tertiary education graduates is small, it remains statistically significant when controlling for occupation and personal characteristics. There are substantial differences across countries. In several countries, VET graduates are less likely to work part-time than those who completed tertiary education (particularly Switzerland, Estonia and Cyprus, but also Latvia, Croatia, the Czech Republic, Slovenia and Iceland). In the Czech Republic, Greece and Belgium, VET graduates more often work part-time than those from general programmes at similar levels.

Figure 4.6. Part-time employment, by education
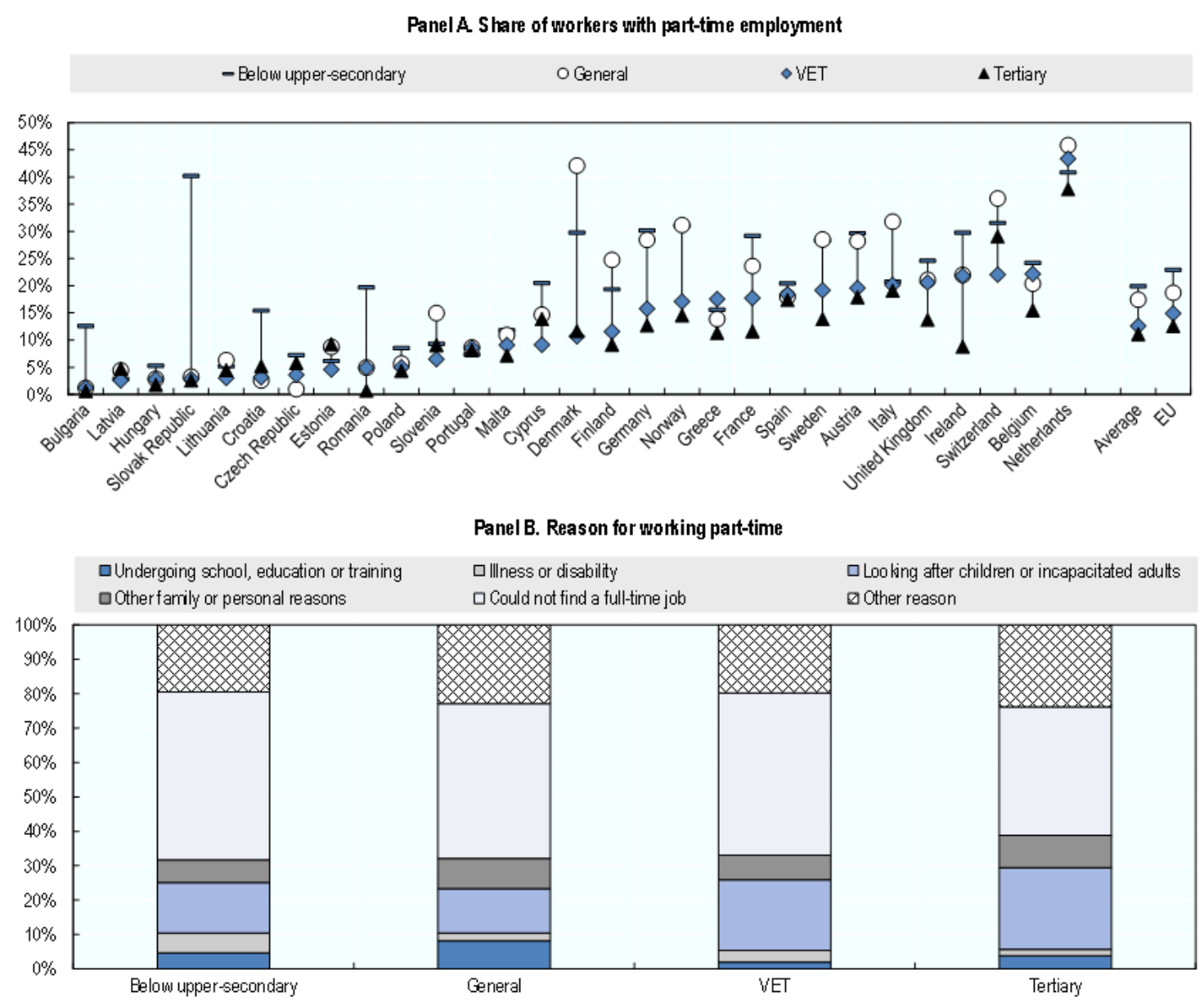

Note: Panel A includes employed individuals aged 15 to 34 not in formal education. Panel B included part-time employed individuals aged 15 to 34 not in education and training.

Source: Authors' calculations using EU-LFS data (2017).

Most part-time work appears to be involuntary. For all education groups, the most frequently stated reason for working part-time is that the person could not find a full-time job (Figure 4.6, Panel B). Moreover, involuntary part-time work is slightly more common among VET graduates (46\%) than among graduates from general programmes $(42 \%)$. In addition, VET and tertiary education graduates are more likely than those from general programmes and those without an upper-secondary degree to be working part-time because 
they are looking after children or incapacitated adults (particularly in Austria, Switzerland, Germany, Estonia, the Netherlands, Sweden and the United Kingdom). Instead, graduates from general programmes who work part-time are more likely to state that they do this because they are in education or training. ${ }^{18}$

\subsection{Types of jobs}

\subsubsection{VET graduates are predominantly employed in services and sales jobs, as well as craft occupations}

The occupational composition of graduate employment shows that most VET graduates are employed in Services and sales jobs (27\%) and Craft and related trades jobs (23\%) (see Figure 4.7, Panel A). 18\% of VET graduates are employed in high-skill occupations (ISCO 1 to 3 ), compared to $26 \%$ of general education graduates. The share of tertiary education graduates in high-skill occupations is significantly larger $(76 \%)$, whereas the share of individuals without an upper-secondary degree in high-skill occupations is much lower $(9 \%)$.

Nevertheless, Panel B shows that there are substantial country differences. For example, the share of VET graduates in high-skill occupations amounts to more than one third in Malta, Germany and Switzerland, where VET graduates relatively often work as Technicians and associate professionals. In the Slovak Republic, the Czech Republic, Lithuania, Hungary, Bulgaria and Poland, a relatively large share of VET graduates (around $20 \%$ ) works as a Plant and machine operator and assembler. Box 4.2 shows that the occupational composition of employment differs between age groups.

\footnotetext{
${ }^{18}$ Note that, even when 'education or training' is reported as the main reason for working part-time, these respondents indicated that their main activity is working: those whose main activity is education/training are excluded from the analyses.
} 
Figure 4.7. Share of graduates across occupations

$\square$ 1. Managers
4. Oenical support workers
7. Oaft and related trades workers

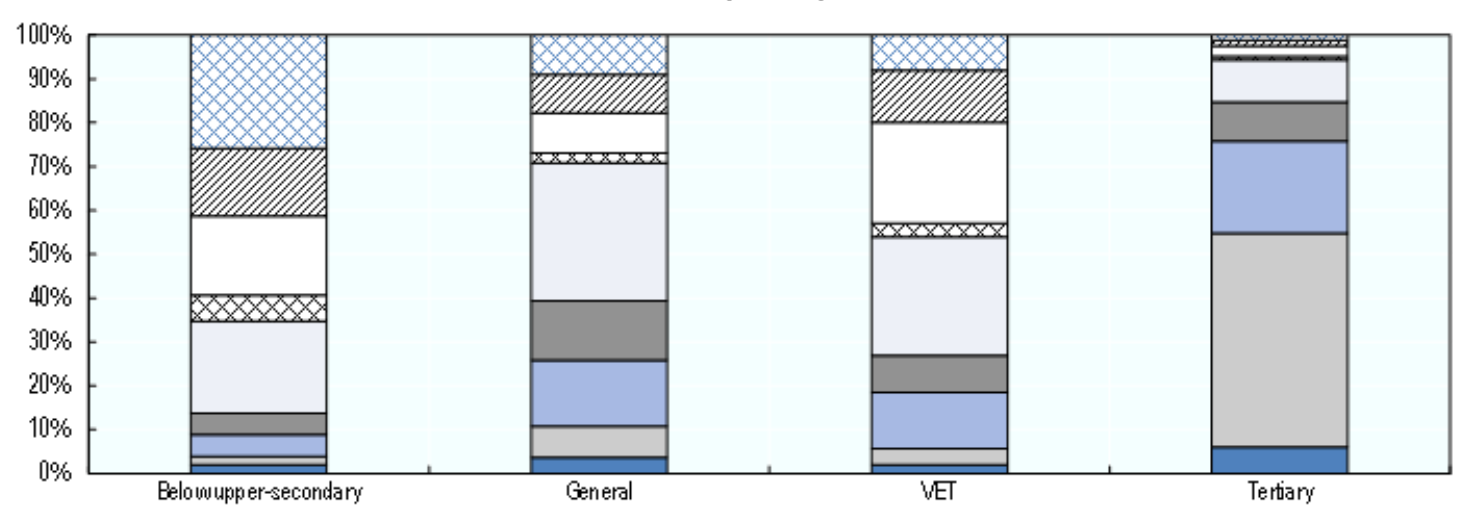

Pane IB. VET occup ations b y country

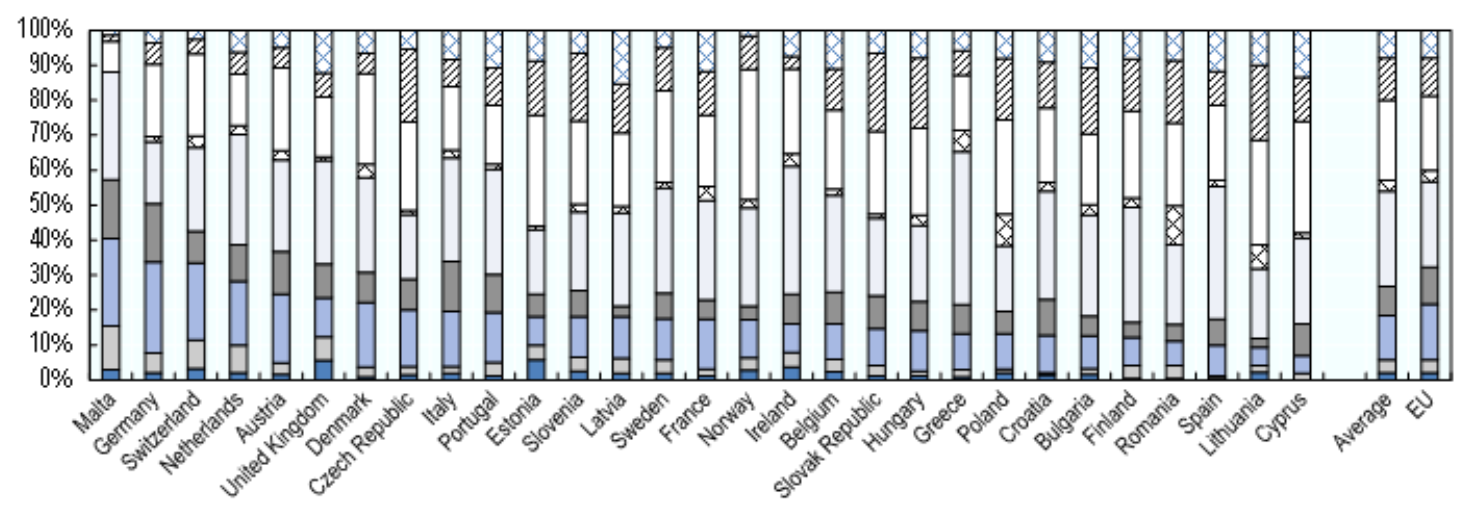

Note: Includes employed individuals aged 15 to 34, not in formal education. In Panel B, countries are sorted by the share of VET graduates who work in high-skill occupations (ISCO 1-3).

Source: Authors' calculations using EU-LFS data (2017). 


\section{Box 4.2. Comparing occupations of different age groups of adults with VET qualifications}

The below figure compares different age groups of adults with VET qualifications in terms of the occupations in which they are employed. Compared to graduates (aged 15 to 34 ), older adults with VET degrees are considerably more likely to be employed in high-skill occupations (managers, professionals, technicians and associate professionals): only $21 \%$ of VET graduates are employed in high-skill occupations, compared to $27.5 \%$ to $29.5 \%$ of older adults with VET qualifications. By contrasts, services and sales jobs and jobs in crafts and related trades are more common among graduates than among older groups of adults.

While these numbers could suggest that VET graduates manage to move into higher-skill occupations as they get older and acquire more work experience, other factors are likely to be at play too. The strong rise in educational attainment in recent decades implies that recent VET graduates are facing much more competition from tertiary education graduates for higher-skill jobs today than they were in the past. This could explain why older groups of adults with VET qualifications, who faced less competition from tertiary education graduates when they entered the labour market, have better chances of being employed in high-skill jobs. At the same time, and as mentioned in Box 4.1, structural changes in the education system might mean that recent VET graduates specialised in different fields and therefore have a different skill set than adults who graduated many years ago. Moreover, barriers to labour market entry for young people might also have increased, especially since the global financial crisis, making it more difficult for young age groups to access higher quality jobs.

Figure 4.8. Occupational composition of adults with VET qualifications Percentage of workers with a VET qualification

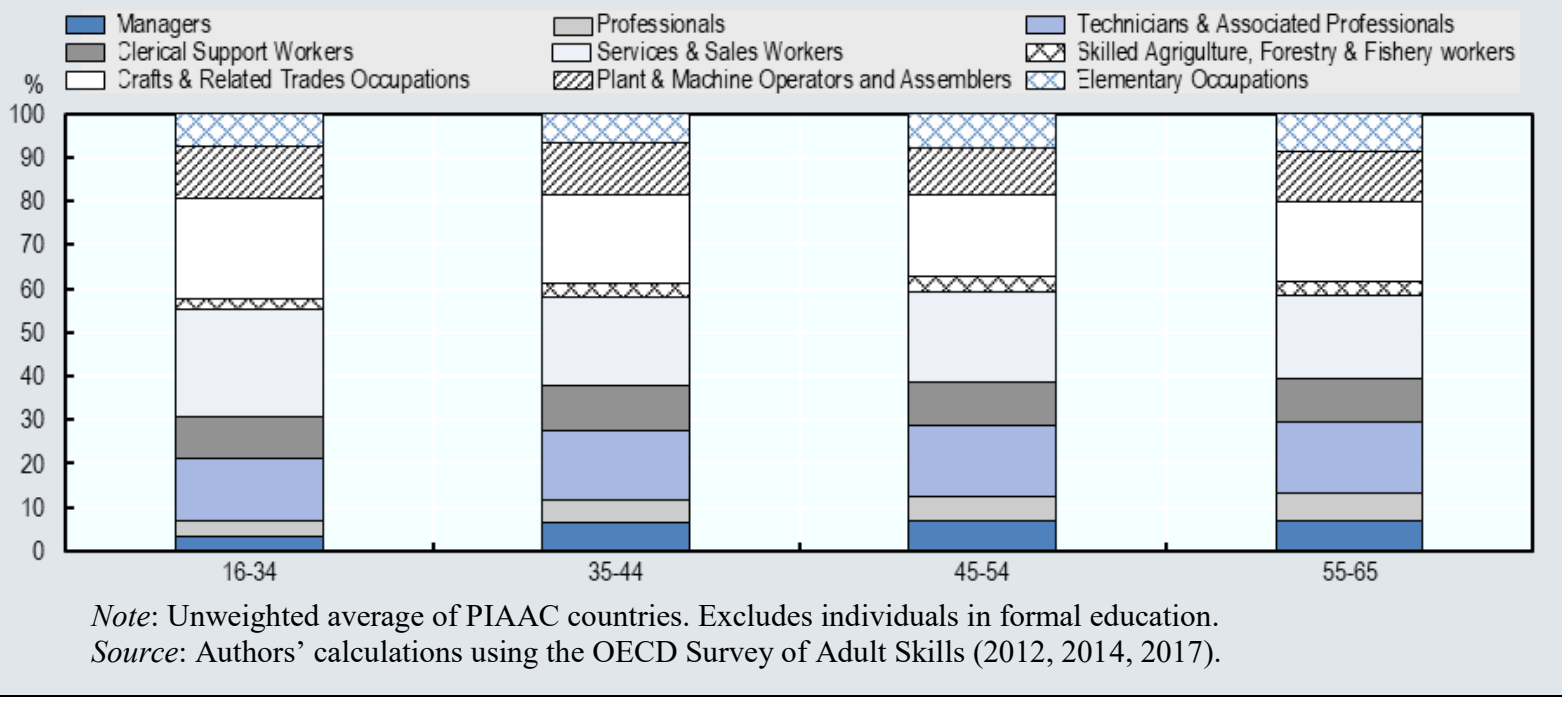

For VET graduates from most fields of study, Services and Sales workers is the most common occupation, see Figure 4.9. The only exceptions are graduates from 'Engineering, manufacturing and construction', 'Agriculture and veterinary' and 'Science, mathematics and computing', who most commonly work as Craft and related trades workers, Skilled agricultural workers and Technicians and associate professionals, respectively. 
Figure 4.9. Share of VET graduates in occupations, by field-of-study

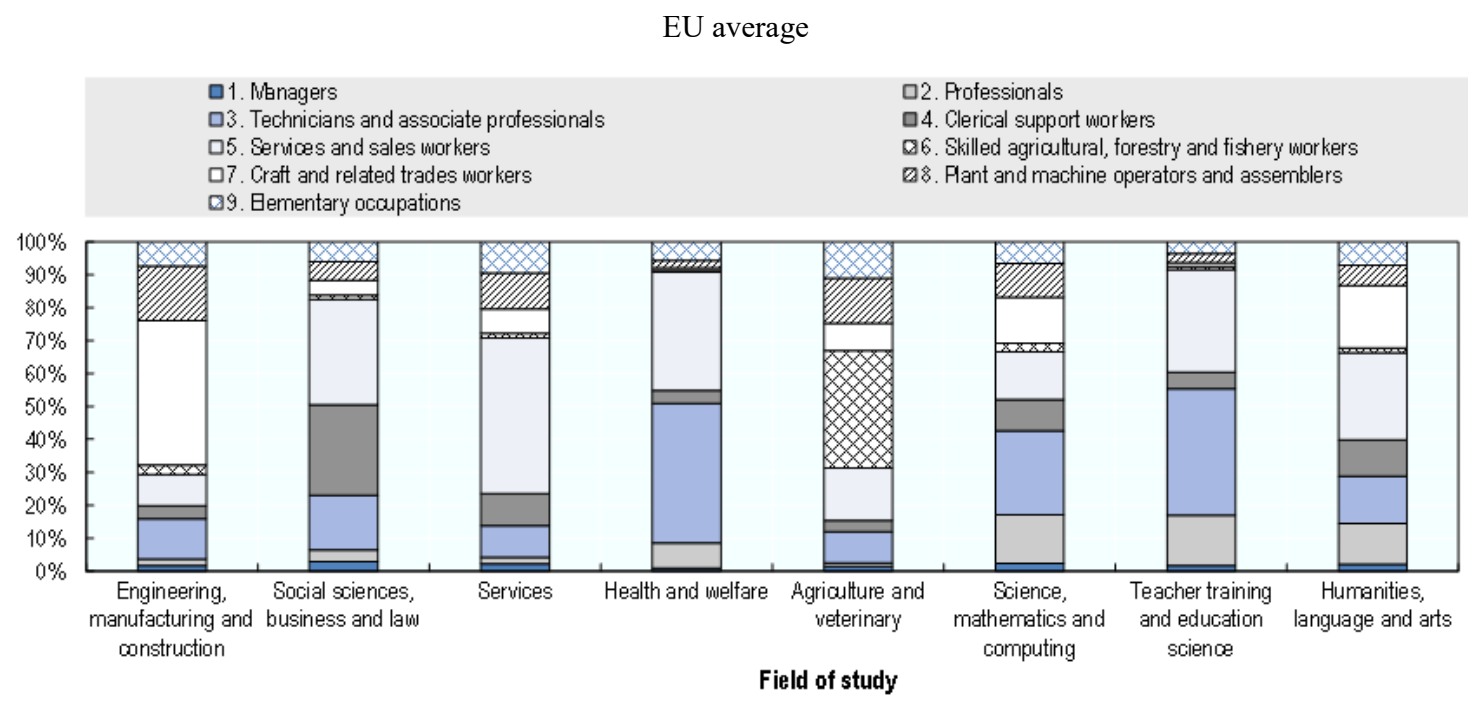

Note: Includes employed individuals aged 15 to 34 not in formal education. The fields of study are sorted by their relative size (see Figure 3.4).

Source: Authors' calculations using EU-LFS data (2017).

Focusing on more detailed occupations, Table 4.1 shows the jobs most commonly held by VET graduates. The table also shows which job are typical VET jobs, in the sense that they are common jobs for VET graduates while being less likely to be important jobs for other types of graduates. For example, while Shop salesperson is the most common occupation among VET graduates, it is not a 'typical VET job', because it is also the most common occupation among graduates from general education and for those without an upper-secondary degree (see Annex C). More surprisingly, Shop salesperson is also one of the most common occupations for tertiary education graduates, even though these graduates are substantially over-qualified for this type of job. In Greece, Cyprus and Spain Shop salesperson is by far the most common occupation for tertiary education graduates (employment share of more than 10\%). Also in Lithuania, Latvia, Croatia, Romania, France, Italy and Ireland, Shop salesperson is among the top-5 occupations for tertiary education graduates (employment share of more than $5 \%$ ).

Personal Care Workers in Health Services, and Waiters and Bartenders are other common occupations for VET graduates that are not 'typical VET jobs', as they are also common occupations for general education graduates. Building Frame and Related Trades Workers are not 'typical VET jobs' because many individuals without an upper-secondary qualification work in this occupation. 
Table 4.1. Most common occupations for VET graduates

Legend: Typical VET occupations (in bold)

\begin{tabular}{|c|c|c|c|c|}
\hline & \multicolumn{2}{|c|}{ Most common occupations for VET graduates } & \multicolumn{2}{|c|}{$\begin{array}{l}\text { Occupations with the highest share of VET graduates } \\
\text { among the employed }\end{array}$} \\
\hline & Occupation & $\begin{array}{l}\text { Employment share } \\
\text { (across) }\end{array}$ & Occupation & $\begin{array}{l}\text { Employment } \\
\text { share (within) }\end{array}$ \\
\hline 1 & Shop Salespersons (522) & $9 \%$ & $\begin{array}{l}\text { Veterinary Technicians and Assistants } \\
\text { (324) }\end{array}$ & $89 \%$ \\
\hline 2 & $\begin{array}{l}\text { Personal Care Workers in } \\
\text { Health Services }(532)\end{array}$ & $4 \%$ & $\begin{array}{l}\text { Chemical and Photographic Products } \\
\text { Plant and Machine Operators (813) }\end{array}$ & $79 \%$ \\
\hline 3 & $\begin{array}{l}\text { Machinery Mechanics and } \\
\text { Repairers (723) }\end{array}$ & $4 \%$ & $\begin{array}{l}\text { Electrical Equipment Installers and } \\
\text { Repairers (741) }\end{array}$ & $74 \%$ \\
\hline 4 & $\begin{array}{l}\text { Building Frame and Related } \\
\text { Trades Workers (711) }\end{array}$ & $4 \%$ & Printing Trades Workers (732) & $74 \%$ \\
\hline 5 & $\begin{array}{l}\text { Electrical Equipment } \\
\text { Installers and Repairers (741) }\end{array}$ & $4 \%$ & $\begin{array}{l}\text { Blacksmiths, Toolmakers and Related } \\
\text { Trades Workers (722) }\end{array}$ & $71 \%$ \\
\hline 6 & Waiters and Bartenders (513) & $3 \%$ & $\begin{array}{l}\text { Wood Processing and Papermaking } \\
\text { Plant Operators (817) }\end{array}$ & $70 \%$ \\
\hline 7 & $\begin{array}{l}\text { Hairdressers, Beauticians } \\
\text { and Related Workers (514) }\end{array}$ & $3 \%$ & Handicraft Workers (731) & $69 \%$ \\
\hline 8 & $\begin{array}{l}\text { Building Finishers and } \\
\text { Related Trades Workers (712) }\end{array}$ & $3 \%$ & Cooks (512) & $69 \%$ \\
\hline 9 & Cooks (512) & $2 \%$ & $\begin{array}{l}\text { Machinery Mechanics and } \\
\text { Repairers (723) }\end{array}$ & $68 \%$ \\
\hline 10 & $\begin{array}{l}\text { Heavy Truck and Bus Drivers } \\
\text { (833) }\end{array}$ & $2 \%$ & $\begin{array}{l}\text { Wood Treaters, Cabinet-makers and } \\
\text { Related Trades Workers (752) }\end{array}$ & $68 \%$ \\
\hline
\end{tabular}

Note: Includes employed individuals aged 15 to 34 not in formal education. Occupations that could not be identified at the 3digit ISCO-08 level are excluded. ISCO-08 occupation codes in parenthesis. 'Typical VET occupations' are occupations that are among the top-10 most common occupations for VET graduates, but not for the other three education groups. *Countries where less than 50 respondents have a certain 3-digit ISCO-08 occupation are excluded from the average.

Source: Authors' calculations using EU-LFS data.

Occupations that are common among VET graduates but less so among other graduates (i.e., 'typical VET jobs') are Machinery Mechanics and Repairers, Electrical Equipment Installers and Repairers and Cooks. Moreover, among all graduates who work in these occupations, the vast majority have a VET degree. Other occupation groups that are common for VET graduates but less so for other graduates are Building Finishers and Related Trades workers, Hairdressers, Beauticians and Related Workers, and Heavy Truck and Bus Drivers. Other occupation groups where the majority of graduate workers have a VET degree are Veterinary Technicians and Assistants (a high-skill occupation), Chemical and Photographic Products Plant and Machine Operators and Wood Processing and Papermaking Plant Operators (part of the occupation group of Plant and machine operators and assemblers), and several occupations within the craft and related occupational group (particularly Printing Trades Workers, Blacksmiths, Toolmakers and Related Trades Workers, Handicraft Workers, and Wood Treaters, Cabinet-makers and Related Trades Workers).

\subsubsection{A significant share of jobs held by VET graduates are at risk of change due to automation}

As VET graduates are more likely to be employed in middle-skill jobs and less likely to hold high-skill jobs compared to other graduates, it could be expected that they are exposed 
to a higher risk of automation. Indeed, as shown in Figure 1.2, many of the occupations that are important for VET graduates have a relatively high risk of automation on average.

Across PIAAC countries, $21.3 \%$ of jobs held currently by VET graduates are highly automatable, which is slightly lower than for general education graduates $(22.4 \%)$, but much higher than for jobs held by tertiary education graduates (9\%). Graduates without an upper secondary degree face the highest risk of automation, with $28 \%$ of them working in jobs at high risk. In the majority of countries, this risk of automation is similar for general education and VET graduates. In the United States, New Zealand, Australia, Denmark and Ireland, VET graduates have a substantially lower risk than general education graduates, while the opposite holds in France and the Slovak Republic.

In all countries, the average risk of automation of jobs held by VET graduates is higher than that of jobs held by tertiary education graduates (see Figure 4.10). Differences between VET and tertiary education graduates are smallest in Mexico, Korea, Denmark and the United States (less than 5 percentage points), and largest in Lithuania (23 percentage points), Belgium (25), and the Slovak Republic (36). In all countries except Lithuania, VET graduates face a lower risk than graduates without an upper secondary degree, although in some countries the difference is only small (e.g. Slovak Republic, Greece, Japan and Poland). Chapter 7 looks further into what explains the differences in automation risk between graduates. 
Figure 4.10. Risk of automation, by education
- Below upper secondary
O General
$\diamond \mathrm{VET}$
$\Delta$ Tertary
Average risk of automation (0-1)

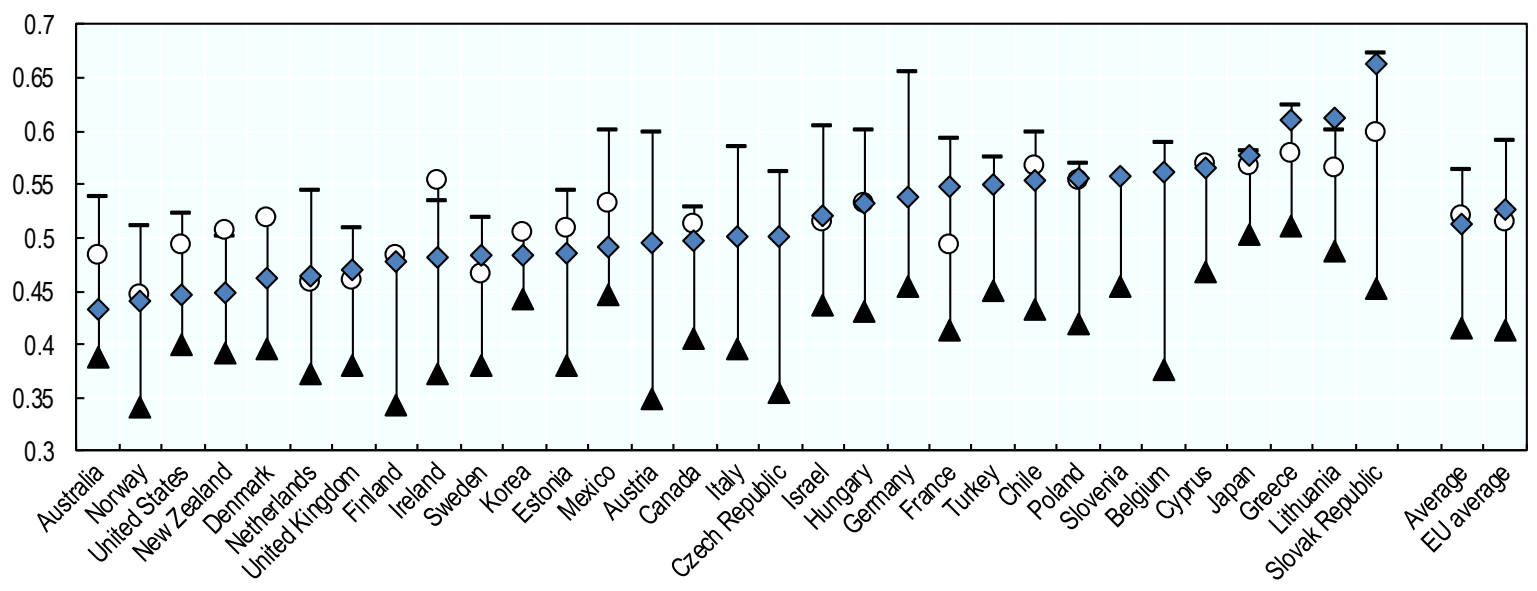

Percentage of jobs at high risk of automation

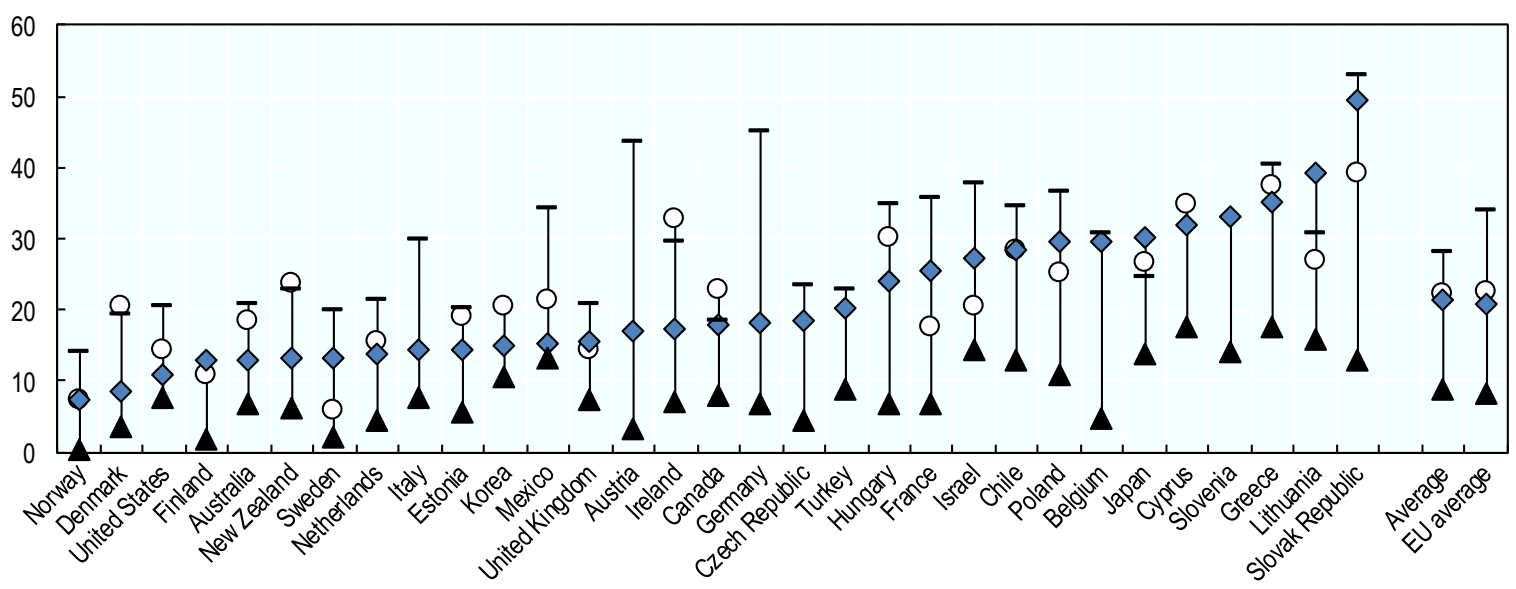

Note: Includes individuals aged 16 to 34 not in formal education. High risk of automation is defined as having a risk of automation of at least 0.7. Belgium refers to Flanders only, the United Kingdom to England and Northern Ireland.

Source: Authors' calculations using the OECD Survey of Adult Skills (2012, 2014, 2017).

\subsubsection{Most VET graduates work in occupations that match their education level}

When individuals are employed in jobs that do not correspond to their skill level or qualification, they are said to be mismatched. Mismatch can be measured in terms of qualification level, field of study, and skills proficiency. Mismatch has been found to have negative consequences for workers, especially in terms of lower wages or job satisfaction

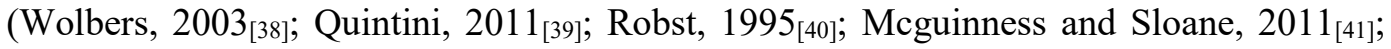
Béduwé and Giret, 2011 $\left.1_{[42]}\right)$. Also for firms, mismatch can be detrimental, as under-qualification is found to have a negative effect on productivity in firms, while over-qualification has positive productivity effects (Kampelmann and Rycx, 2012 ${ }_{[43]}$ ). This finding was recently confirmed for OECD countries (Adalet McGowan and Andrews, $2015_{[44]}$ ), but while over-skilling is found to be associated with higher productivity at the firm level, it contributes to lower labour productivity on aggregate, because it tends to 
constrain the growth of other relatively more productive firms that could more efficiently utilise these workers.

The majority of VET graduates $(67 \%)$ thinks that their education helps them in meeting the demand of their current job (Figure 4.11), which is higher than for general education graduates $(46 \%)$ or those without an upper-secondary degree $(52 \%)$ This may reflect the stronger job-orientation of VET compared to other types of education. Nevertheless, this share is lower for VET graduates than for tertiary education graduates $(75 \%)$.

Figure 4.11. The extent to which graduates think their education helps them in meeting the demands of their current job, by education

EU-average

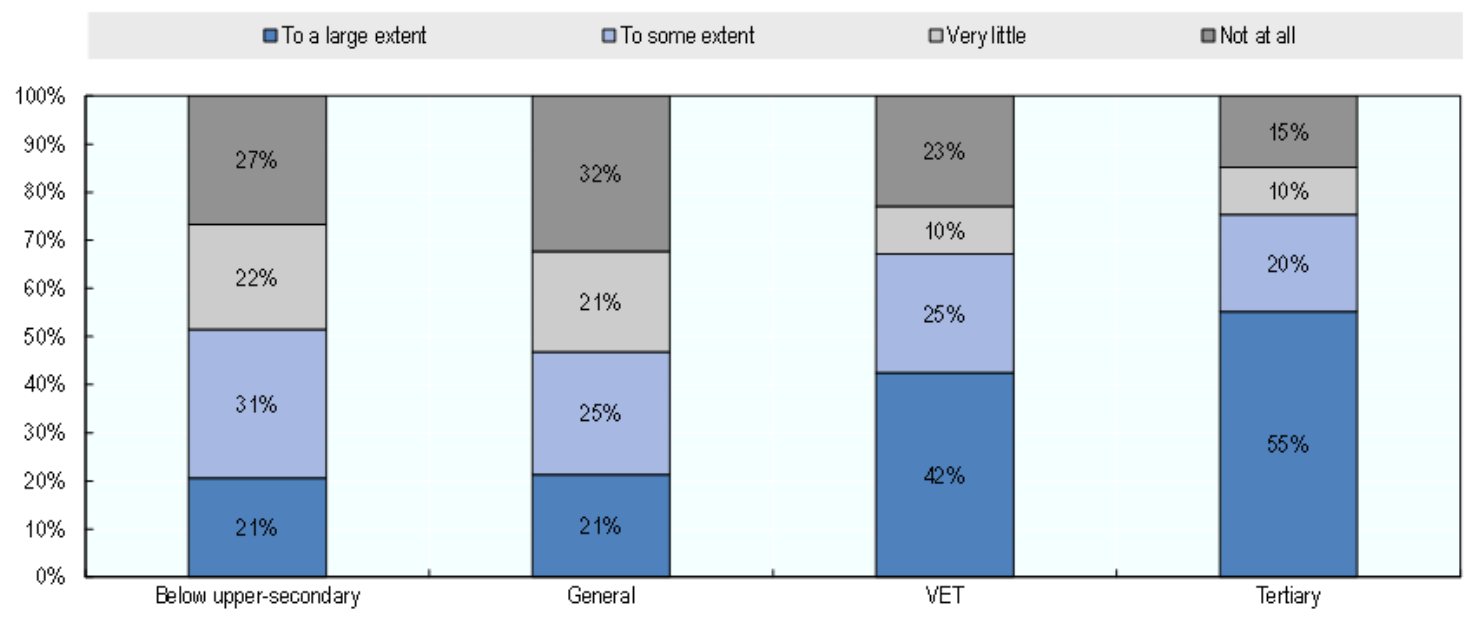

Note: Includes employed individuals aged 15 to 34 not in formal education.

Source: Authors' calculations using the EU-LFS ad-hoc module Young people on the labour market (2016).

Besides the subjective measure of mismatch, it is also possible to objectively analyse the match between graduates' highest obtained qualification and their current job, see Box 4.3. Figure 4.12 shows that around half of VET graduates (53\%) work in an occupation that is a complete match with their study programme, i.e. both in terms of required qualification level as well as the field-of-study of that qualification. This is in line with the share of tertiary education graduates that have a complete match. Moreover, VET graduates are the least likely to be mismatched by qualification level (irrespective of whether or not they are matched by field-of-study). ${ }^{19}$ This finding persists when comparing graduates with similar jobs and personal characteristics.

However, $30 \%$ of VET graduates have a job that matches their qualification level but not their field of study. This is surprising, considering the job-focus of VET. The share of VET graduates who are field-of-study mismatched despite a match in terms of qualification level

${ }^{19}$ Since graduates from tertiary education already have the highest qualification level, they can - by construction - not be underqualified for their job. For graduates from general programmes, it is impossible to measure field-of-study mismatch (as their field of study is general). Those without an upper-secondary qualification can (again, by construction) not be overqualified for their job, but they also do not have a (known) field-of-study. That leaves the VET graduates as the only education group that can both be underqualified and mismatched in terms of field-of-study $(6 \%)$. 
is lowest in Spain, Denmark and Norway (less than 15\%), and highest in Germany, Malta, Greece, Italy, Portugal, Croatia, Slovenia and the Slovak Republic (at least 30\%). Moreover, the share of VET graduates who are mismatched by field of study is larger than among graduates from tertiary programmes (although this difference disappears for graduates with similar jobs, and the difference reverses when additionally controlling for personal characteristics). ${ }^{20}$ Mismatch can be related to many factors, including the adaptability of VET graduates to a demand on the labour market that does not directly matches their education. Moreover, the extent to which mismatch exists depends on the extent to which it is allowed, e.g. through occupational regulations.

Figure 4.12. Match between the level and field of the highest obtained qualification and current employment, by education

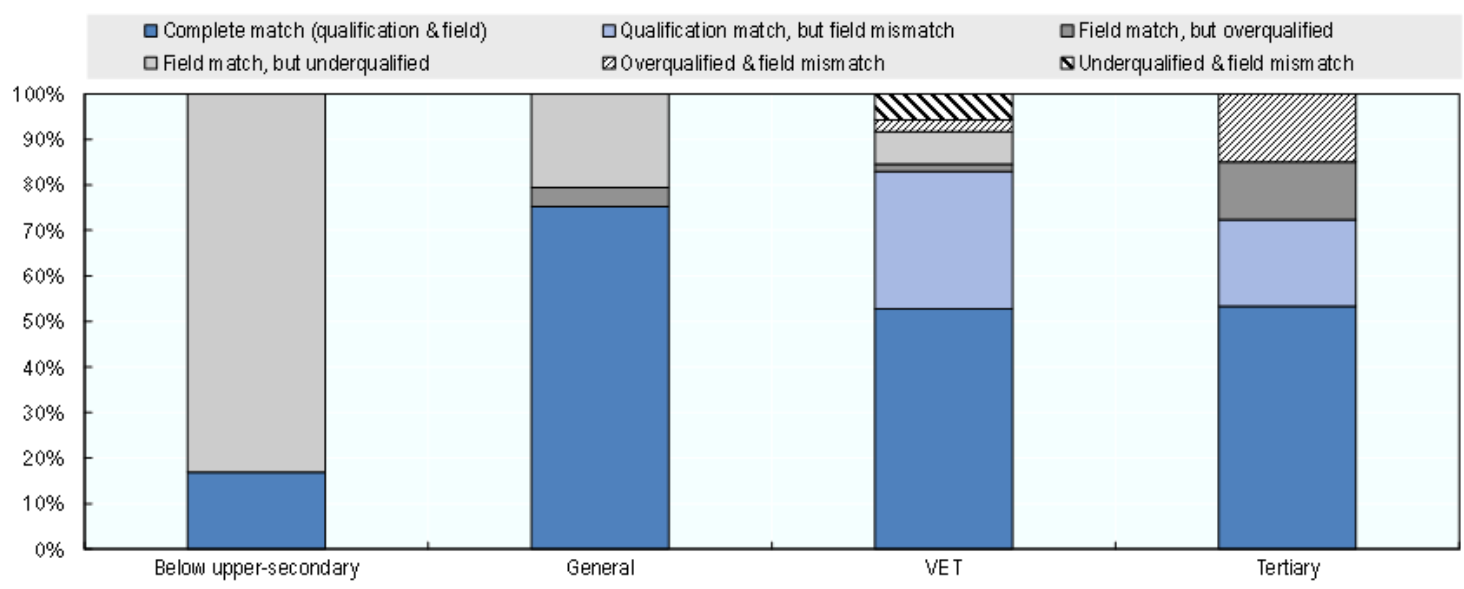

Note: Includes employed individuals aged 15 to 34 not in formal education. See Box 4.3 for details on the methodology to calculate mismatch.

Source: Authors' calculations using EU-LFS data (2017).

Graduates with qualifications in the field of 'Humanities' are the least likely to find a job in a field that is related to their studies: $86 \%$ of VET graduates and $64 \%$ of graduates from tertiary education are field-of-study mismatched when they specialised in 'Humanities'. VET graduates specialised in 'Engineering, manufacturing and construction' are most likely to find a job related to their studies. Among graduates who specialised in the field of 'Services', it appears to be easier for VET than for the higher education graduates to find study-related employment. For any other field of study, VET graduates are less likely to find employment related to their field of study than graduates from tertiary education with a similar field of study. Particularly among those who specialised in 'Computer science' or 'Teacher training and education science', VET graduates are much less likely to work within their field of study than graduates from tertiary education.

${ }^{20}$ Based on a regression analysis including occupation (2-digit ISCO), gender, age, country of birth (foreign-born or not), number of own children, highest educational qualification of the parents, and current region of residence. 
Figure 4.13. Share of graduates mismatched by field of study, by education and field

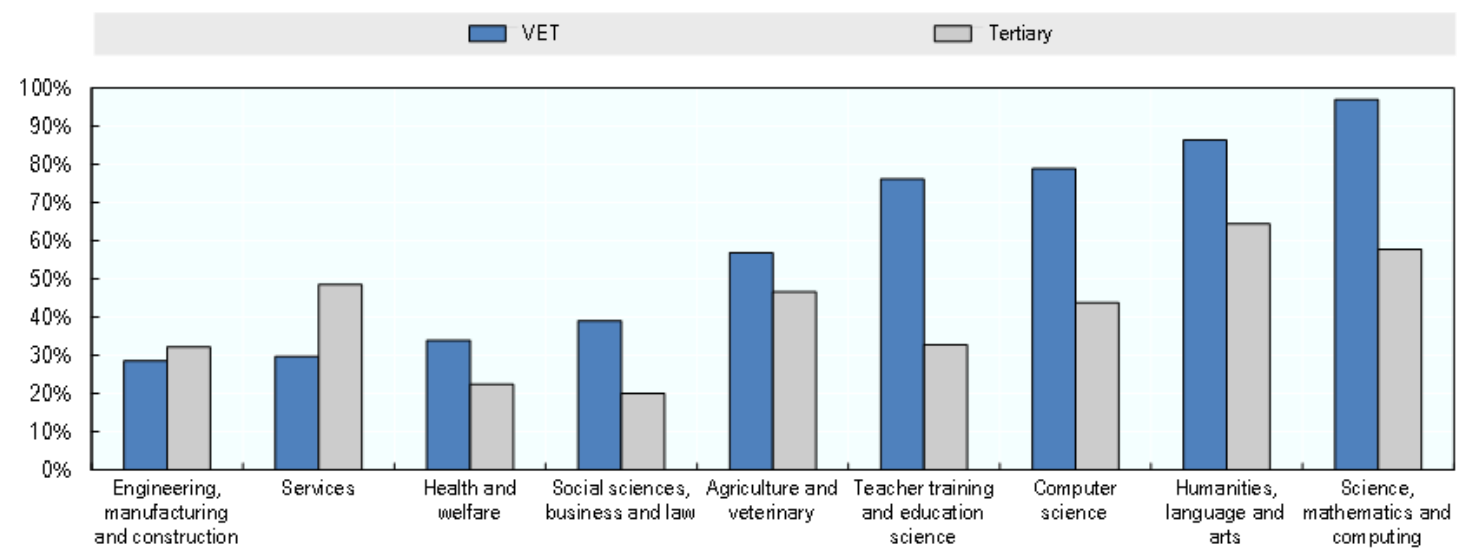

Note: Includes employed individuals aged 15 to 34 not in formal education, irrespective of whether they are matched or not by qualification level See Box 4.3 for details on the methodology to calculate mismatch.

Source: Authors' calculations using EU-LFS data (2017).

\section{Box 4.3. Measuring mismatches between education or skills and current occupation}

Qualification mismatch arises when workers have an educational attainment that is higher or lower than that required by their job. If their education level is higher than that required by their job, workers are classified as over-qualified; if the opposite is true, they are classified as underqualified. In the OECD Skills for Jobs database, the required qualification level is defined as the most common qualification level of individuals working in a specific occupation.

Field-of-study mismatch arises when workers are employed in a different field from what they have specialised in. The matching of occupations and fields of study follows a normative approach, in which occupations (3-digit ISCO) are linked to fields of study based on what educational specialisation is deemed to be appropriate for the jobs in that occupation. Workers who are not employed in an occupation that is considered a good match for their field are counted as mismatched.

Skills mismatch arises when workers have a level of skills that is higher or lower than that required by their job. If their skill level is higher than that required by their job, workers are classified as over-skilled; if the opposite is true, they are classified as under-skilled (Krahn and Lowe, 1998 ${ }_{[45]}$ ). Skills mismatch in the OECD Survey of Adult Skills is calculated by defining a range of skill levels (for literacy, numeracy and problem-solving in technology-rich environments) that are appropriate for the job, based on the skill levels of individuals who self-report being well-matched. Individuals with skill levels outside this range are said to be skill-mismatched (Pellizzari and Fichen, 2017 $[46]$ ).

Source: OECD $\left(2017_{[47]}\right)$

Finally, mismatch can also be measured in terms of skills proficiency rather than qualification level or field. PIAAC data show that on average $9.5 \%$ of VET graduates are over-skilled in literacy, and an additional $2.2 \%$ are under-skilled. While under-skilling is very uncommon among VET graduates in most countries, it is the case for more than $6 \%$ of graduates in the Slovak Republic and Cyprus. VET graduates have a lower probability of 
being over-skilled than general and tertiary education graduates, but a higher probability of under-skilling: $14 \%$ of general and $16 \%$ of tertiary education graduates are over-skilled, and $1-1.5 \%$ of general and tertiary education graduates are under-skilled on average across PIAAC countries. By contrast VET graduates are less likely to be under-skilled than graduates without an upper-secondary degree and more likely to be over-skilled. When comparing graduates with similar personal characteristics working in similar occupations and industries, VET and general education graduates have the same incidence of over- and under-skilling. The differences between VET and tertiary education graduates, as well as those without an upper secondary education degree, remain significant even when controlling for personal and job characteristics.

Figure 4.14. Literacy proficiency mismatch

Percentage of employed VET graduates who are under- or over-skilled for their job

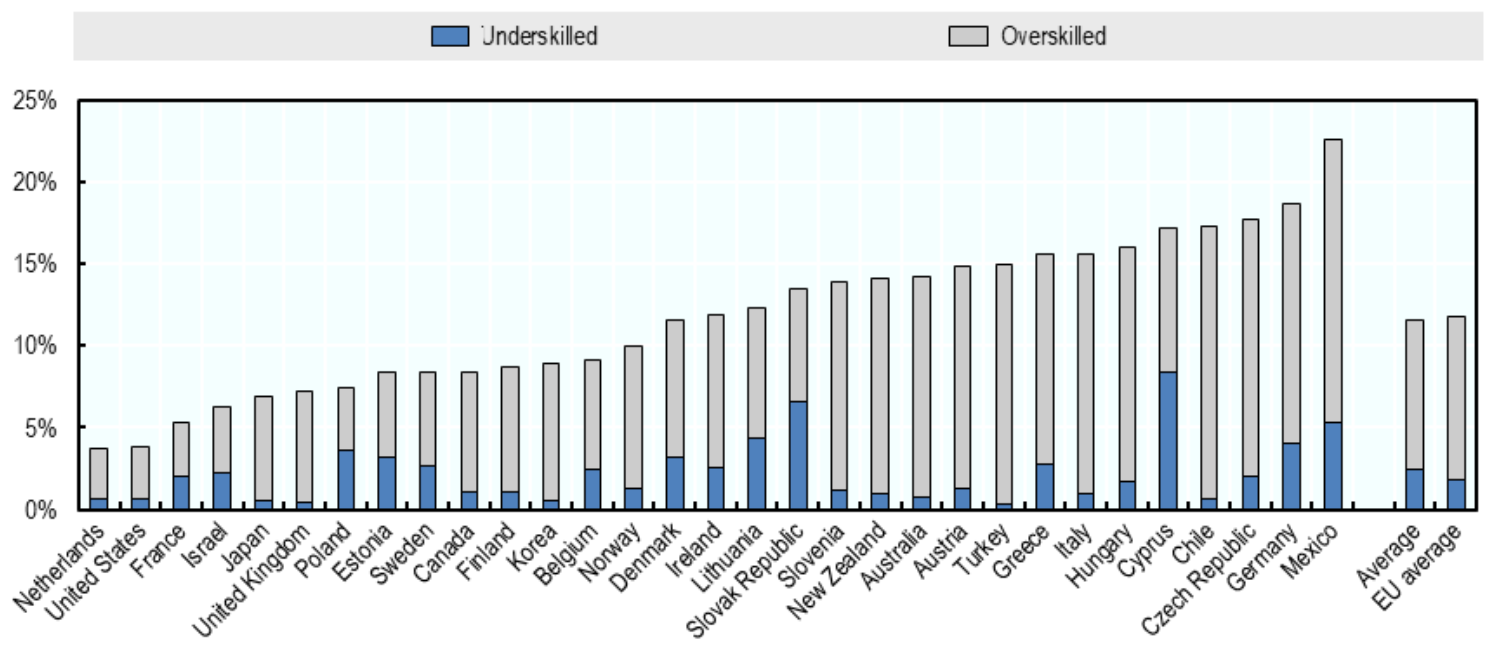

Note: Includes individuals aged 16 to 34 not in formal education. Belgium refers to Flanders only, the United Kingdom to England and Northern Ireland. See Box 4.3 for details on the methodology to calculate mismatch. Source: Authors' calculations using the OECD Survey of Adult Skills $(2012,2014,2017)$.

\subsubsection{A large share of VET graduates work in small enterprises}

Firm size is an important driver of job quality (see next section for a discussion of the job quality dimensions). Workers in smaller firms have, for example, lower access to skills development and weaker employee representation and voice (OECD, 2019 [48]; Eurofound, $\left.2017_{[49]}\right)$. At the same time, workers in SMEs are found to have lower work demands in the job, and there is some evidence to suggest that workers in SMEs have higher job satisfaction (Eurofound, 2017 [49]; De Kok et al., 2011 ${ }_{[50]}$ ). In 2017, 99.8\% of all enterprises in the non-financial business economy in the EU-27 countries employed fewer than 250 persons, accounting for $70 \%$ of total employment (Eurostat data). Compared to tertiary education graduates, graduates from general and vocational education are more likely to be employed in small enterprises employing at most 250 employees ( $62 \%$ of general education and VET graduates, versus $51.5 \%$ of tertiary education graduates). An even larger share of graduates without an upper secondary degree work in small enterprises (70\%). VET graduates are slightly more likely to be working in micro-enterprises (at most 10 employees) than graduates from general education. When comparing graduates employed in similar occupations and industries (with similar personal characteristics, including cognitive skills), VET and general education graduates have the same probability 
of working in a small firm, and this probability is significantly higher than among tertiary education graduates and lower than among graduates without an upper secondary degree.

In addition, VET and general education graduates are less likely than graduates from tertiary education to be working in expanding firms - firms that have seen an increase in the number of employees over the previous 12 months (21-22\% vs. 26\%). On the other hand, VET graduates are less likely than general education graduates and graduates without an upper secondary degree to be working for an employer that has seen a decrease in the number of employees. When controlling for industry and occupation, as well as personal characteristics, graduates from VET and general education as well as those with below upper secondary education have similar probabilities of working in a firm with decreasing numbers of employees, and this probability is significantly higher than for tertiary education graduates. A similar analysis for the probability of working in an expanding firm, shows that general education graduates are significantly less likely to work for a growing employer than VET graduates, and that the probability is similar for VET and tertiary education graduates as well as those without an upper secondary education degree.

Figure 4.15. Distribution of graduates by firm size, PIAAC average

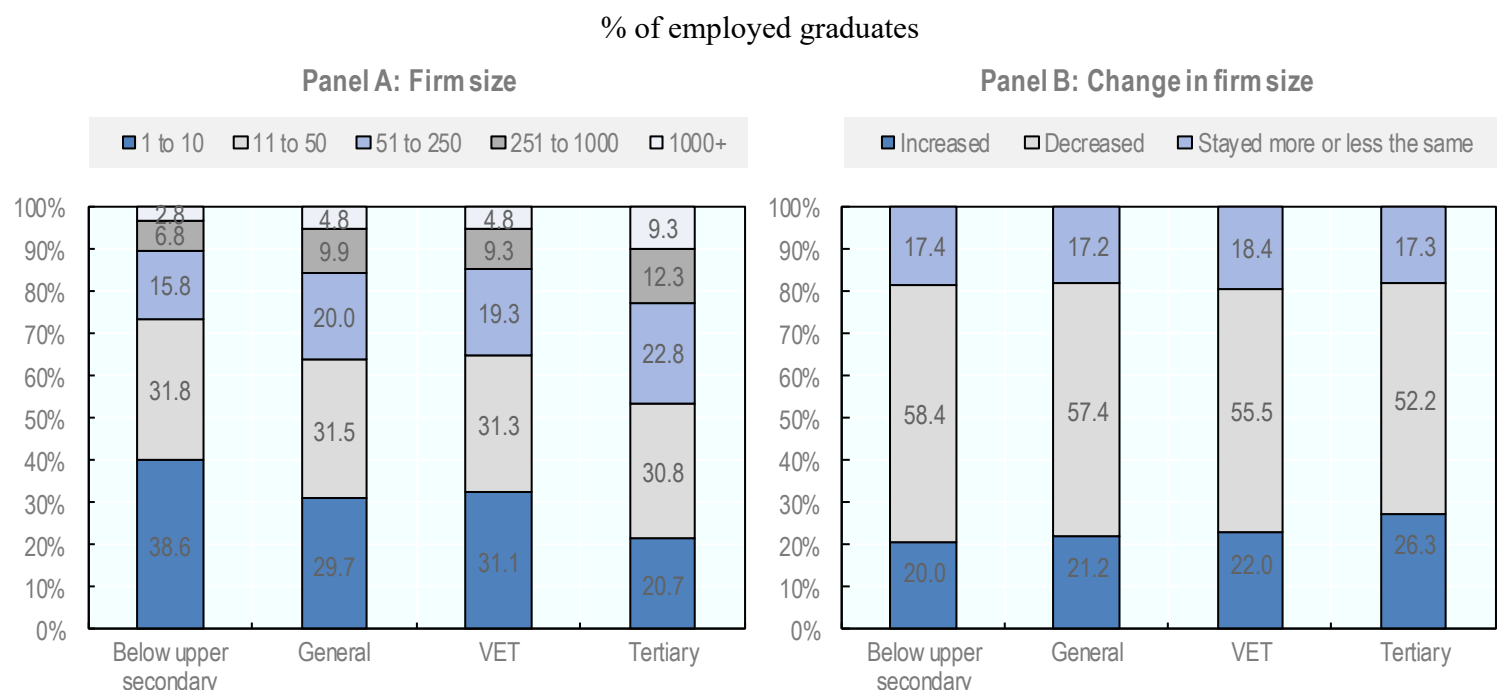

Note: Includes graduates aged 16 to 34 who are not in formal education.

Source: Authors' calculations based on the Survey of Adult Skills (2012, 2014, 2017).

\subsubsection{The incidence of self-employment is similar across education groups}

By innovating and seizing opportunities, entrepreneurs drive national and local economic change and competitiveness. Fostering self-employment is therefore crucial for innovation and job creation. However, often self-employed workers, like other non-standard workers, have limited access to social protection (OECD, 2018 [51] . Precarious working conditions can be particularly challenging for self-employed workers without employees (OECD, $\left.2019_{[52]}\right)$. Although the average share of self-employed individuals across EU countries is similar for all graduates (around 8\%), see Figure 4.16, there are substantial differences between countries. In some countries, such as Italy, Germany and Austria, VET graduates are the least likely education group to be self-employed. In the United Kingdom, on the other hand, VET graduates are more likely to be self-employed compared to other graduates. 
Figure 4.16. Share of self-employed individuals, by education

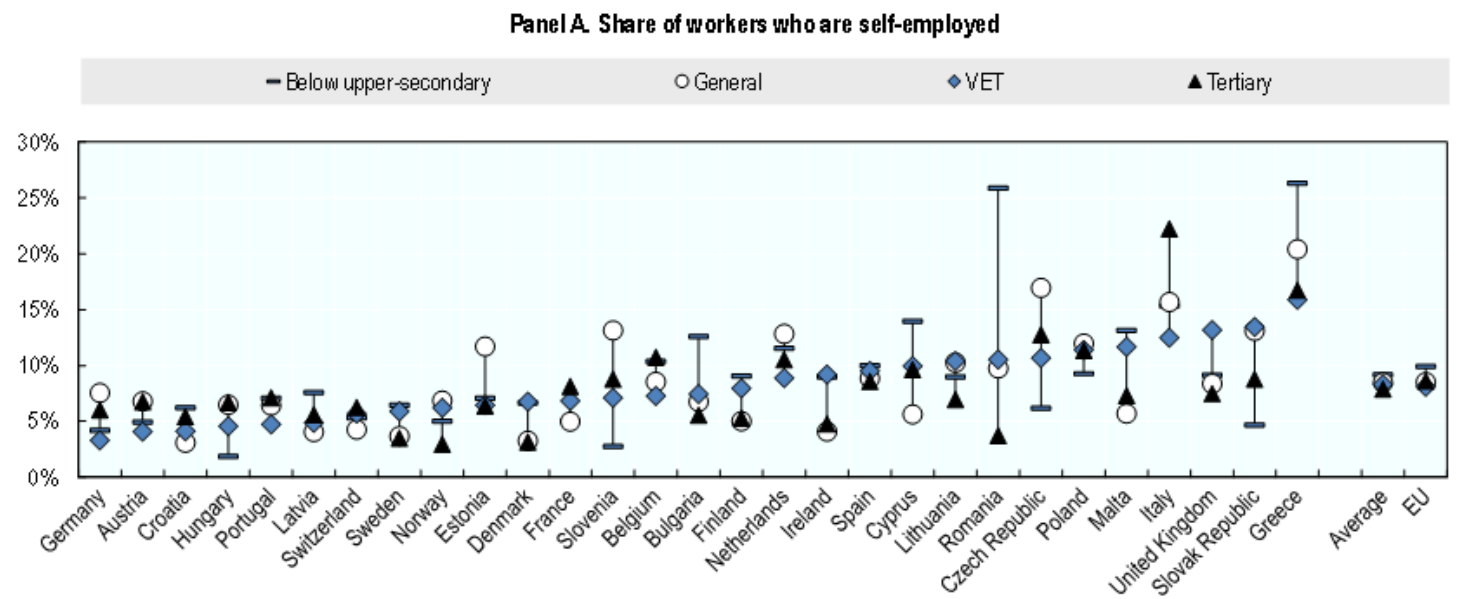

Panel B. Share of self-employed who have no employees

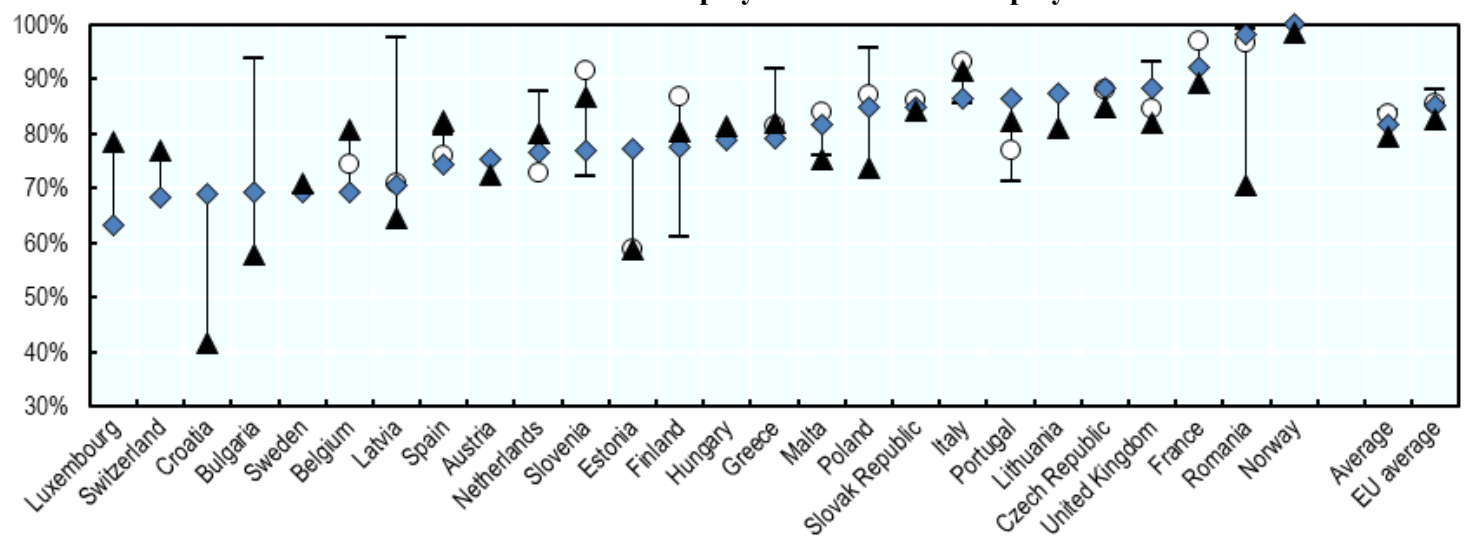

Note: Includes employed individuals aged 15 to 34 not in formal education.

Source: Authors' calculations using EU-LFS 2017 (Panel A) and EU-SILC 2014-2017 (Panel B)

Across European countries, self-employed graduates are roughly equally likely to have no employees in all education groups: $81.7 \%$ of self-employed VET graduates have no employees, compared to $83.4 \%$ of general education graduates, $79.3 \%$ of tertiary education graduates, and $84.2 \%$ of graduates without an upper secondary education degree. ${ }^{21}$ The differences between education groups are not statistically significant also when controlling for personal characteristics and the occupation and industry of the self-employed. However, in some countries the differences are substantial. In, Slovenia and Finland, for example, self-employed general education graduates are more likely then VET graduates to have no employees, while the opposite holds in countries like Estonia and Portugal. According to the 2017 EU-LFS ad hoc module on the self-employed, self-employed VET graduates without employees are more likely than other graduates to

${ }^{21}$ Similar results are found when using the 2017 EU-LFS ad hoc module on self-employment, which shows that $79.9 \%$ of VET graduates who are self-employed have no employees, compared to $78.5 \%$ and $78.2 \%$ of self-employed general and tertiary education graduates, respectively (EU-average). The share is slightly higher among those without an upper secondary education degree (83.2\%). Sample sizes do not permit using these data at the country level. 
report that the reason for not having employees is that they primarily want to employ themselves. This is the case for $32 \%$ of VET graduates (EU-average), compared to $26 \%$ of general education graduates and $27 \%$ of tertiary education graduates and graduates without an upper secondary degree. Moreover, $9.5 \%$ of VET graduates who are self-employed without employees are in economically dependent self-employment, meaning that they worked during the last 12 months for only one client or for a dominant client, and this client decided about their working hours. ${ }^{22}$ This is only slightly higher than among general and tertiary education graduates $(8.5 \%)$ and those without an upper secondary education degree (7.4\%). Box 4.4 describes a new form of self-employment that has been growing substantially in recent years, namely online platform work.

\section{Box 4.4. Education levels of online platform workers}

The digital revolution is promoting new forms of employment mediated by online platforms. Early signs show that online works has been growing rapidly. Nonetheless, this segment of the labour market is still very small. Most of the existing studies covering a range of countries have typically produced estimates that vary between $0.5 \%$ and $3 \%$ of the labour force. Most vacancies are posted from OECD countries, particularly in the United States, but the majority of workers are based in non-OECD countries.

The tasks posted on online platforms (and carried out online) can be broadly classified into six groups: i) writing and translation, ii) software development and technology, iii) creative and multimedia, iv) sales and marketing support, v) professional services, and vi) clerical and data entry. While many of these tasks would be classified as high-skill, some, like sales, clerical and data entry tasks, would only require low or medium-level skills.

Most estimates regarding the profile of platform workers suggest that these workers are predominantly highly educated. A recent survey among European platform workers showed that more than $50 \%$ of these workers have a tertiary qualification. Even when controlling for age - which is important given that platform workers are younger than the average worker - this education effect remains. Many of these highly educated platform workers are overqualified for the tasks they carry out.

Generally, VET graduates from certain fields should have the vocational skills to carry out a subset of the tasks posted on online platforms. Online platform workers also need solid (basic) digital skills to access and work on the platforms, as well as certain employability skills, such as financial literacy, self-motivation, organisational and interpersonal skills, and English language skills. VET systems will need to ensure that these skills are developed alongside vocational skills that support VET graduates in successfully accessing online platform jobs.

Source: (OECD, 2019[52]; OECD, 2018[53]), (Pesole et al., 2018[54]), (ILO, 2018[55]), (Broughton et al., 2018[56])

\subsection{Job quality}

The OECD has developed a framework to measure and assess the quality of jobs that considers three objective and measurable dimensions: earnings quality, labour market security, and quality of the working environment (Cazes, Hijzen and Saint-Martin,

${ }^{22}$ This is the operational definition of economically dependent self-employment adopted by Eurostat in the context of the 2017 EU-LFS ad hoc module on self-employment. 
$\left.2015_{[57]}\right)$. Together, these three dimensions provide a comprehensive assessment of job quality. The job quality framework was designed to measure quality at the country level, but proxies for the three dimensions can be used to measure individuals' job quality.

\subsubsection{VET and general education graduates have similar wage levels}

On average, VET and general education graduates have similar median hourly wages, which are around $25 \%$ lower than those of tertiary education graduates. In all countries VET and general education graduates have lower hourly wages than tertiary education graduates. The difference between VET and tertiary education graduates is most pronounced in Luxembourg, Estonia, Hungary, Lithuania, Latvia, Romania and Portugal, where VET graduates' wages are between $60 \%$ and $65 \%$ of tertiary education graduates' wages. The difference is relatively small in Denmark, Iceland and Norway, where VET graduates earn $90 \%$ or more of tertiary education graduates' wages. In most countries, wages of VET graduates are close to those of general education graduates. However, in some countries VET graduates have considerably higher wages than general education graduates (e.g. Denmark, Iceland and Norway), while in others, like Luxembourg and Estonia, the opposite holds. In all countries, VET graduates earn more than those without an upper secondary education degree, with the latter having wages that are on average equal to $65 \%$ of the wages of tertiary education graduates.

Figure 4.17. Relative median hourly wages of graduates

Index: 100= median hourly wage of tertiary education graduates

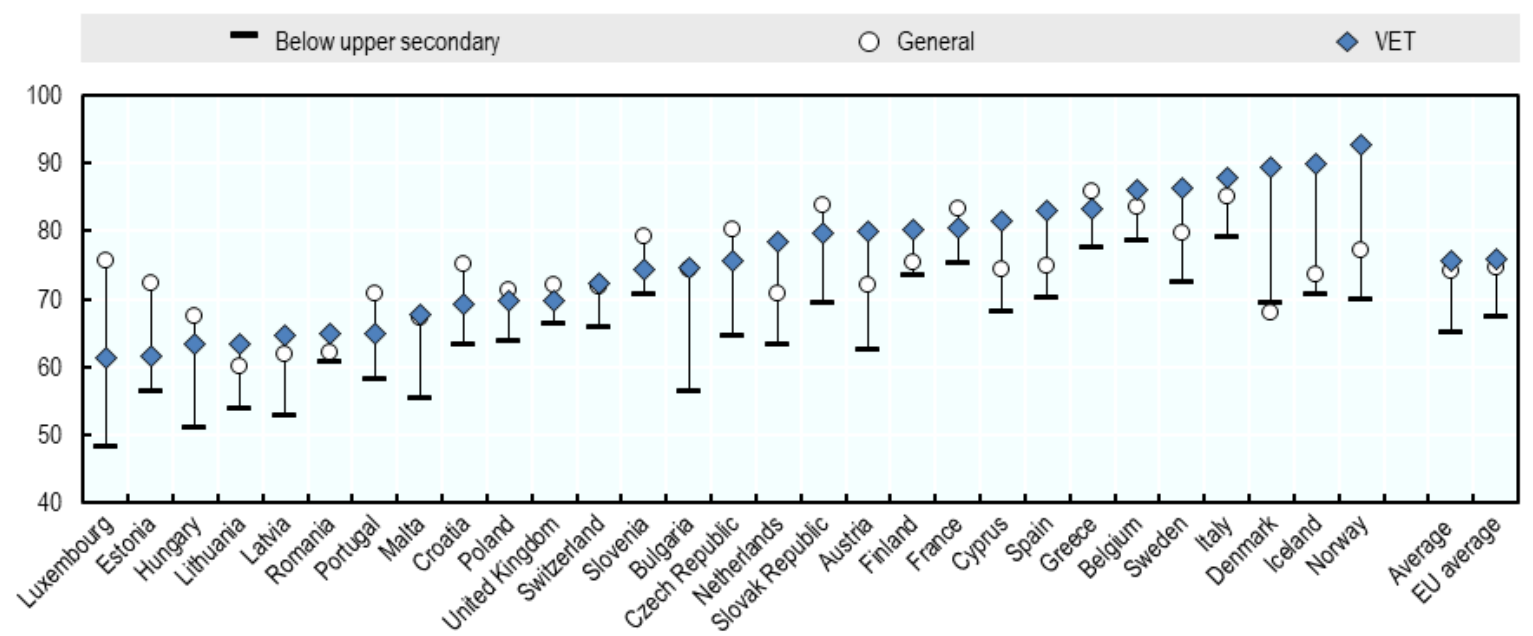

Note: Includes individuals aged 15 to 34 not in formal education. Hourly wages are derived from annual earnings, by accounting for months spent in employment in the income reference year and information on average hours worked.

Source: Authors' calculations using EU-SILC data (2014-2017).

Also when controlling for additional personal and workplace characteristics, the differences between education groups remains. ${ }^{23}$ Table 4.2 shows that general education graduates have slightly lower hourly earnings compared to the VET graduates (3.1\% difference), but that this gap is much smaller than the gap between VET and tertiary

${ }^{23}$ The regressions in Table 4.2 use PIAAC data instead of EU-SILC data (as in Figure 4.17) in order to be able to control for skill levels. 
education graduates (21\%). The gap between VET and general education graduates is also substantially smaller than between VET graduates and those without an upper secondary degree $(3.1 \%$ versus $7.2 \%)$. When further controlling for industry and occupation, the gap between general and vocational education graduates remains almost the same, while the gap between VET and tertiary education graduates falls from $21 \%$ to $9.4 \%$. The gap between VET graduates and those without an upper secondary degree falls slightly from $7.2 \%$ to $5.3 \%$. These regression results show that VET graduates earn slightly more than general education graduates when they are employed in similar occupations and industries. At the same time, they earn significantly less than tertiary education graduates, - even when they are employed in similar occupations and industries.

Table 4.2. Wage regression results, by age group

OLS results (dependent variable $=$ log hourly wage)

\begin{tabular}{|c|c|c|c|c|c|c|c|c|}
\hline & \multirow{2}{*}{\multicolumn{2}{|c|}{$\begin{array}{c}\text { Graduates } \\
16-34\end{array}$}} & \multicolumn{6}{|c|}{ Older age groups } \\
\hline & & & \multicolumn{2}{|c|}{$35-44$} & \multicolumn{2}{|c|}{$45-54$} & \multicolumn{2}{|c|}{$55-65$} \\
\hline & (i) & (ii) & (i) & (ii) & (i) & (ii) & (i) & (ii) \\
\hline $\begin{array}{l}\text { Below upper } \\
\text { secondary (vs. VET) }\end{array}$ & $\begin{array}{r}-0.072^{\star * *} \\
(0.013)\end{array}$ & $\begin{array}{r}-0.053^{* \star *} \\
(0.012)\end{array}$ & $\begin{array}{r}-0.112^{* \star *} \\
(0.012)\end{array}$ & $\begin{array}{r}-0.075^{\star \star \star} \\
(0.011)\end{array}$ & $\begin{aligned}-0.122^{* * *} \\
(0.011)\end{aligned}$ & $\begin{array}{r}-0.086^{* \star *} \\
(0.011)\end{array}$ & $\begin{array}{r}-0.091^{\text {*** }}(0.012)\end{array}$ & $\begin{array}{r}-0.053^{* \star *} \\
(0.012)\end{array}$ \\
\hline General (vs. VET) & $\begin{array}{l}-0.031^{* * *} \\
(0.011)\end{array}$ & $\begin{array}{r}-0.028^{* * *} \\
(0.010)\end{array}$ & $\begin{array}{l}0.027^{* *} \\
(0.013)\end{array}$ & $\begin{array}{r}0.011 \\
(0.012)\end{array}$ & $\begin{array}{r}0.018 \\
(0.012)\end{array}$ & $\begin{array}{l}-0.008 \\
(0.011)\end{array}$ & $\begin{array}{r}0.015 \\
(0.015)\end{array}$ & $\begin{array}{r}-0.009 \\
(0.014)\end{array}$ \\
\hline Tertiary (vs. VET) & $\begin{array}{r}0.210^{* * *} \\
(0.009)\end{array}$ & $\begin{array}{r}0.094^{* * *} \\
(0.009)\end{array}$ & $\begin{array}{r}0.288^{* * *} \\
(0.009)\end{array}$ & $\begin{array}{r}0.160^{\star * *} \\
(0.009)\end{array}$ & $\begin{array}{r}0.318^{* * *} \\
(0.009)\end{array}$ & $\begin{array}{r}0.165^{* * *} \\
(0.010)\end{array}$ & $\begin{array}{r}0.296^{\star \star *} \\
(0.012)\end{array}$ & $\begin{array}{r}0.143^{* * *} \\
(0.012)\end{array}$ \\
\hline Occupation controls & No & Yes & No & Yes & No & Yes & No & Yes \\
\hline Industry controls & No & Yes & No & Yes & No & Yes & No & Yes \\
\hline Observations & 27155 & 26774 & 21937 & 21590 & 21679 & 21313 & 14291 & 14035 \\
\hline
\end{tabular}

Note: Excludes individuals who are in formal education. Includes controls for gender, literacy proficiency ( 5 categories), age (3 categories), number of children, migrant status, tenure with current employer (4 categories), firm size (5 categories), part-time working hours, contract type and country. Occupation controls are 1-digit ISCO, industry controls are 1-digit ISIC. Standard errors are reported in parenthesis. $* * * \mathrm{p}<0.01$, ** $\mathrm{p}<0.05, * \mathrm{p}<0.1$. Hourly wages include bonuses and are trimmed at the bottom and top $1 \%$ per country.

Source: Authors' calculations using PIAAC data

The remaining columns of Table 4.2 repeat this exercise for older age groups, to see if the wage differences stay the same over time or become more or less pronounced. As with other age group analyses presented earlier, it has to be noted that differences between these groups do not only reflect how differences between graduates evolve over time, but also how VET systems and educational attainment levels have changed. The (small) wage difference between general education and VET graduates disappears entirely when looking at older age groups. The gap between general and tertiary education graduates is larger for older age groups, and reaches its peak among 45-54 year olds. Similarly, the gap between VET graduates and those without an upper secondary degree is largest for 45-54 year olds.

\subsubsection{Job security is relatively high among VET graduates}

As discussed above, VET graduates have relatively low unemployment rates, contributing to high job security. In addition, when they are employed, graduates from VET are less likely than general education graduates to have a temporary contract (16 versus $20 \%$, see Figure 4.19). This contributes further to their job security, as workers on temporary contracts generally have lower protection and security. The main exception is Portugal, where VET graduates are the most likely group to have a temporary contract. By contrast, in Austria, Denmark, Switzerland, Norway, Germany and Finland, the prevalence of 
temporary contracts is lower among VET graduates than among graduates from other educational levels/types.

The most common reason for having a temporary contract is that the person could not find a permanent job. VET graduates mention this reason more often than other graduates $(66 \%$, compared to $54 \%$ among general education graduates, $60 \%$ among tertiary education graduates, and $63 \%$ among those without an upper-secondary degree). Austria is an exception, where the majority of graduates from all education groups indicate that they actually did not want a permanent job.

Figure 4.18. Temporary contracts, by education

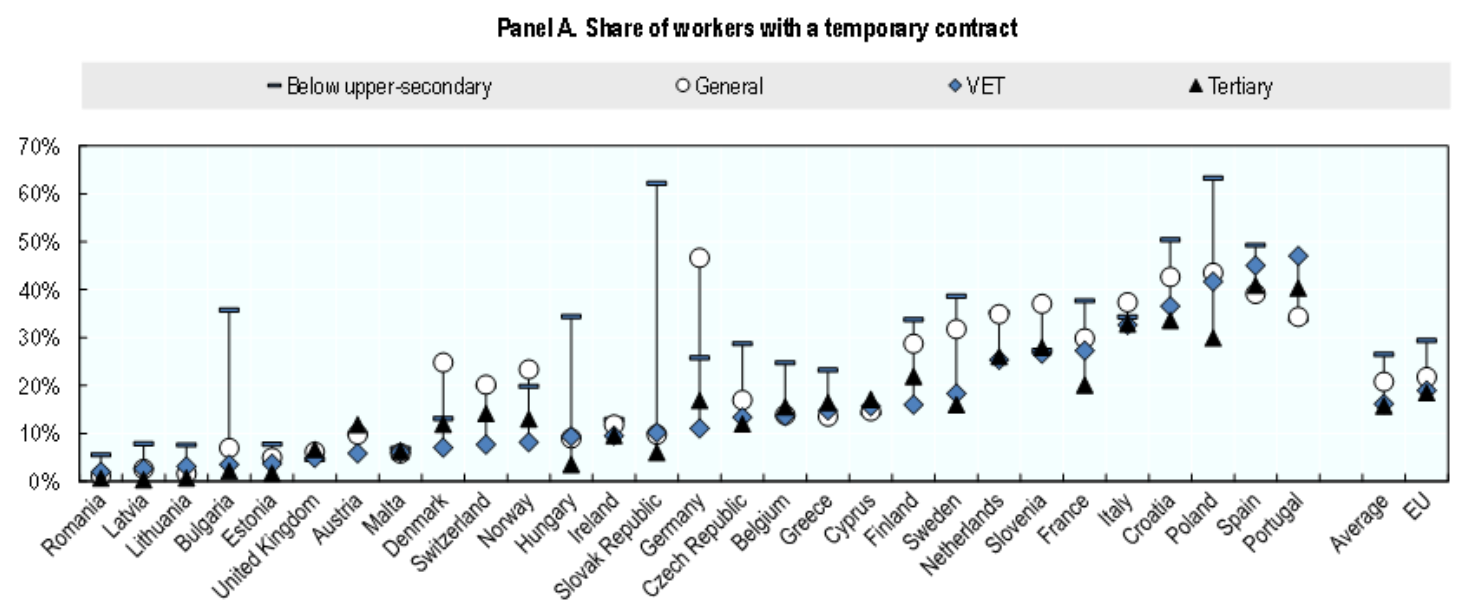

Panel B. Reas on for temporary employment

$\square$ Could not find a permenent job $\quad \square$ Did not want a permenent job $\quad \square$ Contrad for a probationary period $\quad \square$ Contract covers a period of training

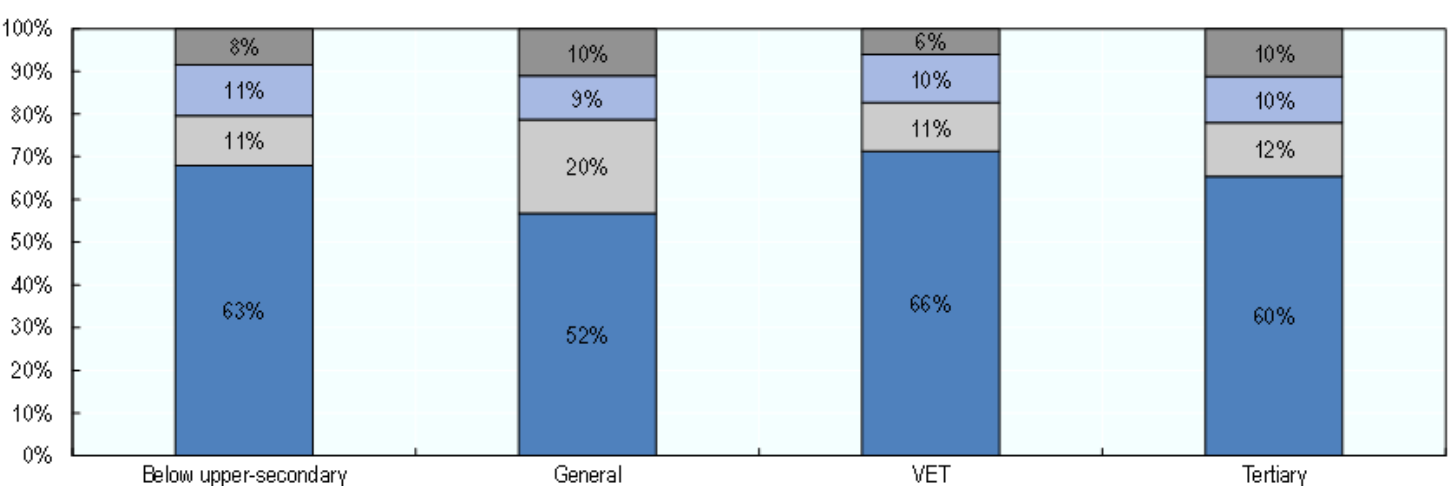

Note: Includes employed individuals aged 15 to 34 not in formal education.

Source: Authors' calculations using EU-LFS data (2017).

One may expect that the probability of having a permanent contract increases as graduates accumulate more work experience. Indeed, for all types of graduates, the probability of having a temporary contract is lower among those who graduated longer ago (see Figure 4.19). This declining probability is particularly outspoken for general education graduates during the first nine years after graduation. While VET graduates have a significantly lower probability of being employed on a temporary contract at the beginning of their working life compared to general education graduates, this gap disappears among those with at least five years of (work) experience. Moreover, VET graduates remain significantly more likely 
to have a temporary contract than graduates from tertiary education, even ten years after graduation. Individuals without an upper-secondary degree are most likely to have a temporary contract, irrespective of the number of years since they obtained their highest qualification.

Figure 4.19. Workers' probability of holding a temporary contract, by years since graduation

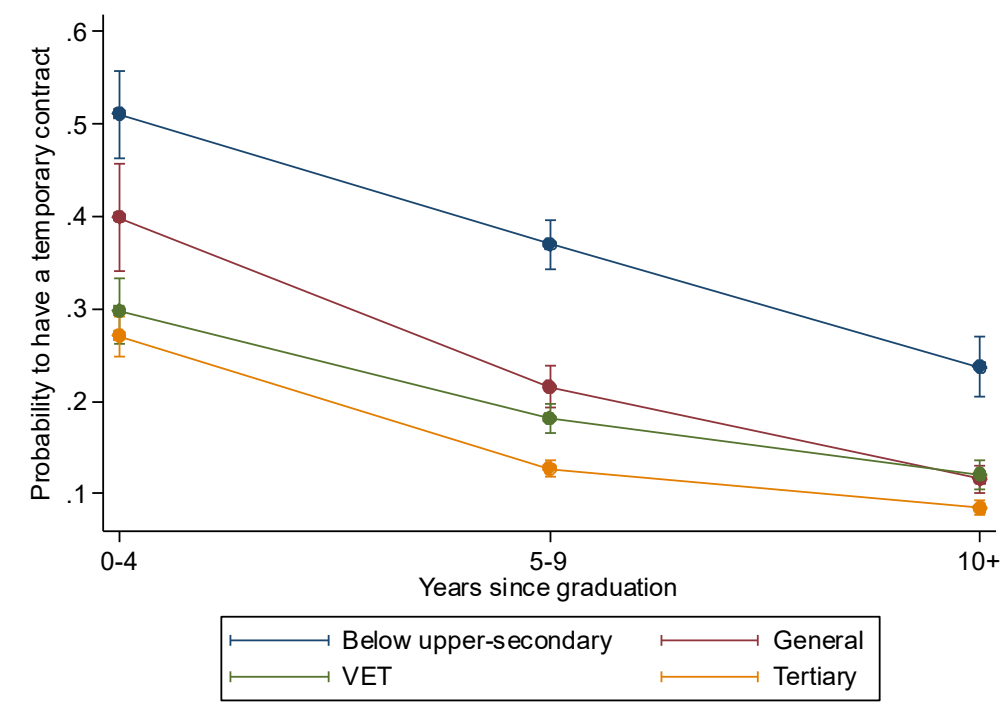

Note: Includes employed individuals aged 15 to 34 not in formal education. The figure shows marginal effects with $95 \%$ confidence intervals after a weighted logit regression analysis, with an indicator variable with value 1 if the respondent has a temporary contract as the dependent variable. Independent variables are type of education, years since graduation, gender, region fixed effects, and occupation fixed effects (2-digit ISCO). Source: Authors' calculations based on EU-LFS data (2017).

\subsubsection{VET graduates are more likely to work in physically demanding jobs than general education graduates}

Non-economic aspects of jobs, including the nature and content of the work performed, working-time arrangements and workplace relationships, are equally important aspects of job quality.

Working more than 50 hours per week is an important indicator of job strain. On average, around $4 \%$ of individuals aged 15 to 34 indicate that their usual workweek exceeds 50 hours (see Figure 4.20). This percentage is similar across education groups. However, there are some outliers. In Cyprus, Slovenia and the Slovak Republic, the share of VET graduates with long workweeks is higher than among the other education groups. In Greece and the United Kingdom, the share of VET graduates with long workweeks is relatively high compared to other countries, but not as high as among graduates of some of the other education groups within their country.

Another aspect of job strain is the extent to which workers are exposed to physical health risk factors, such as tiring or painful positions and carrying or moving heavy loads. As Figure 4.21 shows, $59.6 \%$ of VET graduates report working physically for long periods every day, which is higher than for general education graduates $(52.8 \%)$ and especially tertiary education graduates $(22.1 \%)$. However, it is substantially lower than among graduates without an upper secondary degree (66.6\%). 
Figure 4.20. Share of individuals who work more than 50 hours per week, by education

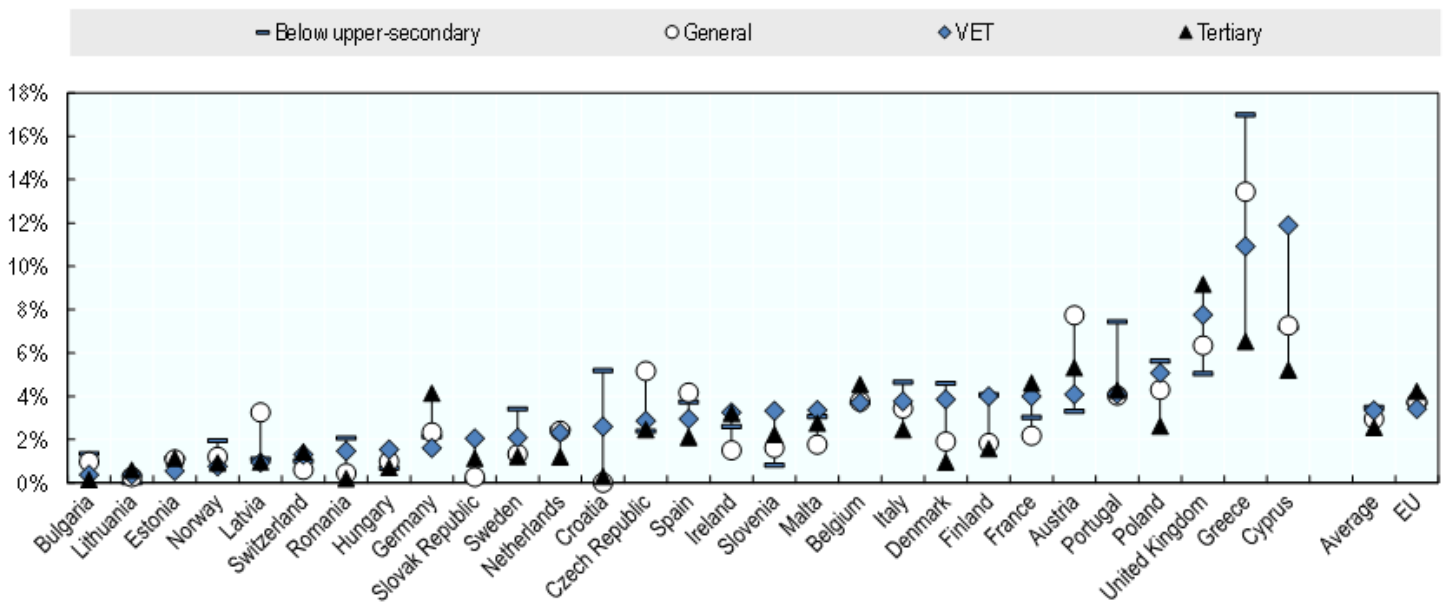

Note: Includes employed individuals aged 15 to 34 not in formal education. Source: Authors' calculations using EU-LFS data (2017).

Over $70 \%$ of VET graduates work physically for long in Cyprus, Lithuania, Slovak Republic, Poland and Turkey, while only around $45 \%$ of VET graduates do so in Italy, Korea, Japan and Mexico. Only $18.4 \%$ of VET graduates say never to work physically for long, while this is the case for $24.4 \%$ of general education graduates and $50.5 \%$ of tertiary education graduates. Even fewer graduates without an upper secondary degree say never to work physically for long (13.8\%). Also when controlling for skill levels and personal characteristics, as well as for industry and occupation, the difference in the probability of working physically for long every day between VET and other graduates remains. This means that VET graduates carry out more physically demanding tasks than general and tertiary education graduates, even when having comparable skill levels and being employed in similar occupations and industries.

Figure 4.21. Frequency of working physically for long

$\%$ of employed graduates

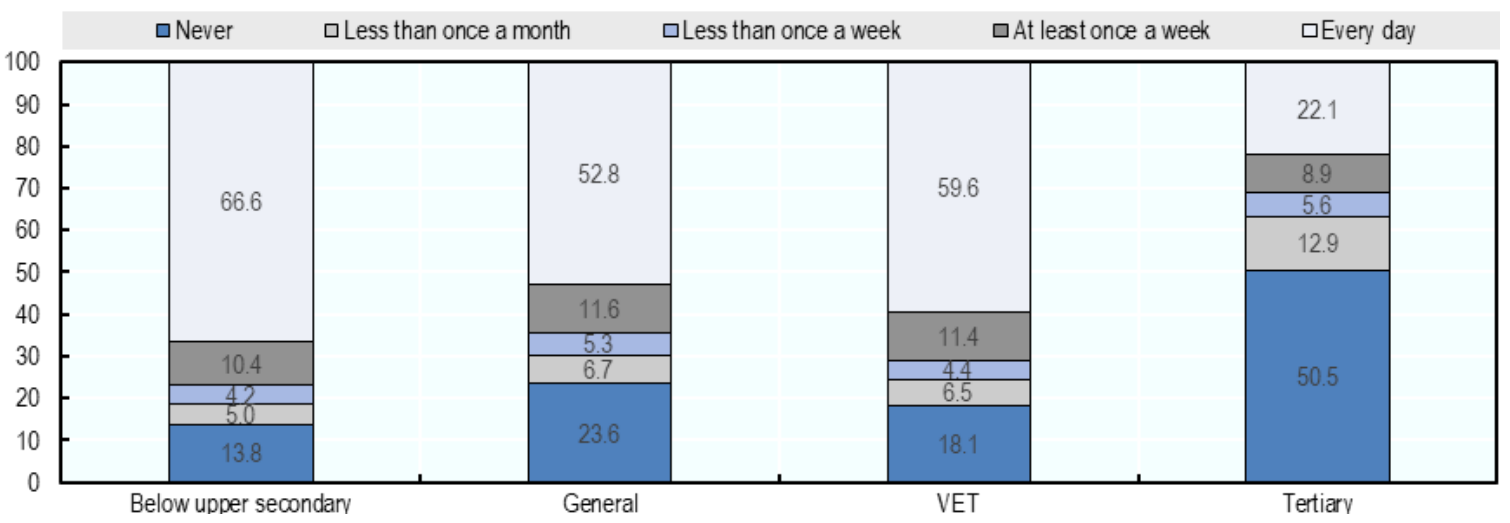

Note: Includes employed individuals aged 16 to 34 not in formal education. Unweighted average of PIAAC countries.

Source: Authors' calculations based on the Survey of Adult Skills (2012, 2014, 2017). 


\subsubsection{Recent VET and general education graduates are equally likely to have supervisory responsibilities at work}

Having career progression opportunities in your job, such as the option of being promoted to a job with more supervisory responsibilities over others, is an important driver of job motivation, and therefore job quality. On average, 14\% of VET and general education graduates have supervisory responsibilities, compared to $23 \%$ of tertiary education graduates and $8 \%$ of those without an upper-secondary degree. In most countries, VET graduates are equally likely as graduates from general education to have supervisory responsibilities in their job. Exceptions are Denmark, Ireland Switzerland and Norway, where VET graduates are more likely to have supervisory responsibilities, and Slovenia, Austria, Portugal and Estonia, where they are less likely than general education graduates to have supervisory tasks.

Figure 4.22. Share of workers with supervisory responsibilities, by education

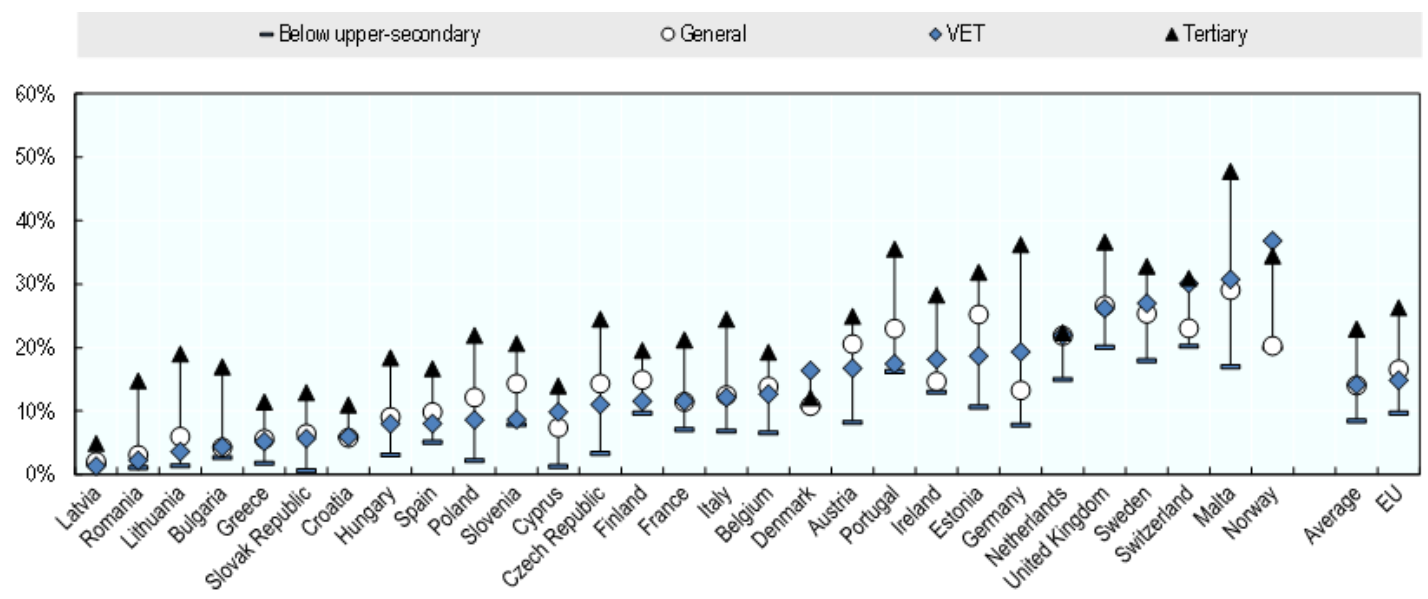

Note: Includes employed individuals aged 15 to 34 not in formal education.

Source: Authors' calculations using EU-LFS data (2017).

One could expect that the probability of having supervisory responsibilities increases with age and with experience (i.e. years since graduation). Figure 4.23 shows that this is indeed the case for all education groups. However, for VET graduates the probability to supervise others increases at a much slower rate than for graduates from general education. Recent vocational education graduates (less than 5 years after graduation) have a slightly higher probability of having supervisory responsibilities in their job than recent graduates from general education, but this advantage seems to disappear with time. VET graduates who obtained their degree at least 10 years ago or who are 30 to 34 years old, have a significantly lower probability of carrying out supervisory tasks than general education graduates with similar characteristics. This pattern suggests that VET graduates enter the labour market with an advantage (potentially because they have stronger job-specific skills and/or previous work experience), but have less opportunities for upward mobility than general education graduates. The difference in the probability to have supervisory responsibilities between VET graduates and tertiary education graduates and those without an upper-secondary degree remains substantial and statistically significant across age groups and groups with different years since graduation. 
Figure 4.23. Workers' probability to supervise others

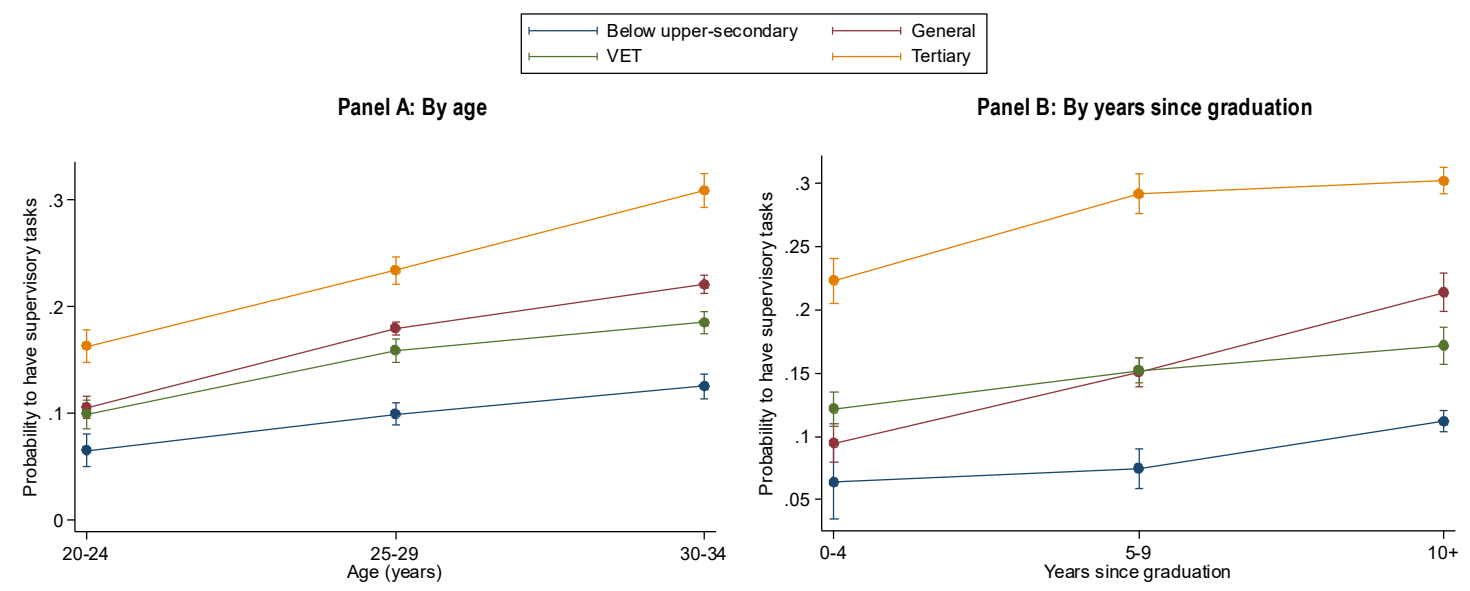

Note: Includes employed individuals aged 15 to 34 not in formal education. Both panels show marginal effects with $95 \%$ confidence intervals after a weighted logit regression, with an indicator variable with value 1 if the respondent supervises others in their current job as the dependent variable. Independent variables are type of education, age (panel A) or years since graduation (panel B), gender, region and occupation fixed effects (2-digit ISCO).

Source: Authors' calculations based on EU-LFS (2017).

\subsubsection{VET and general education graduates have similar exposure to high performance work practices}

Expose to high performance work practices (HPWP), which include both aspects of work organisation - team work, autonomy, task discretion, mentoring, job rotation, applying new learning - and management practices - employee participation, incentive pay, training practices and flexibility in working hours - , is an important aspect of job quality. Higher exposure to HPWP has been linked to higher wages, higher job satisfaction, lower job-related stress, and higher labour productivity (OECD, 2016 $[58]$ ).

On average, VET and general education graduates are equally likely to be employed in jobs with high HPWP. However, their exposure to HPWP is lower than among tertiary education graduates (with the exception of graduates in Australia and Denmark), and higher than among graduates without an upper secondary degree (except in Greece, Ireland, Belgium, Poland and the Czech Republic). Tertiary education graduates are especially more likely to organise their own time, plan their own activities, teach other people, participate in training, and have flexible working hours (see Panels B and C of Figure 4.24). By contrast, VET and general education graduates more frequently cooperate with others in their job than tertiary education graduates. Differences between general education and VET graduates are relatively small for all aspects of HPWP, with the exception of performance pay which is more common among VET graduates. When comparing graduates employed in similar occupations and industries and with similar personal characteristics (including skills), the exposure to HPWP is the same for VET, general education and tertiary education graduates, and it is significantly higher than for graduates without an upper secondary degree. 
Figure 4.24. Exposure to high performance work practices

$\begin{array}{ccc}- \text { Below upper secondary } & \bigcirc \text { General } & \diamond \text { VET } \\ & \text { Panel A: Share of jobs with high HPWP } & \end{array}$

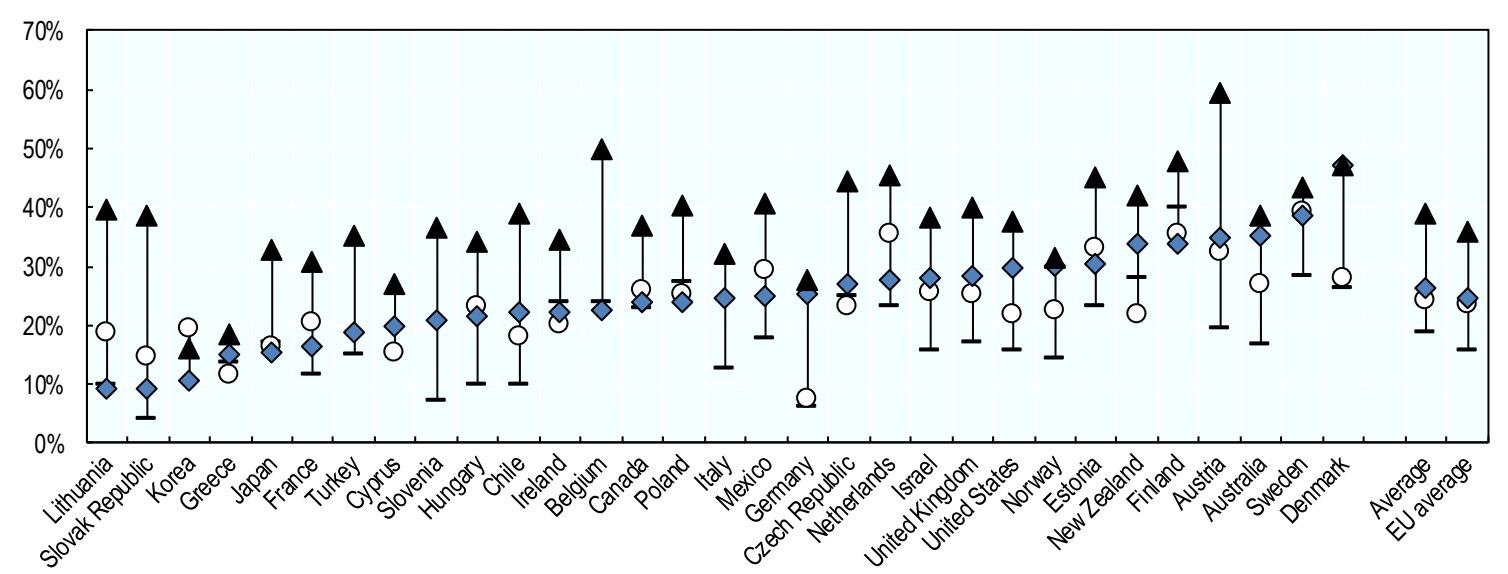

Panel B: Work organisation
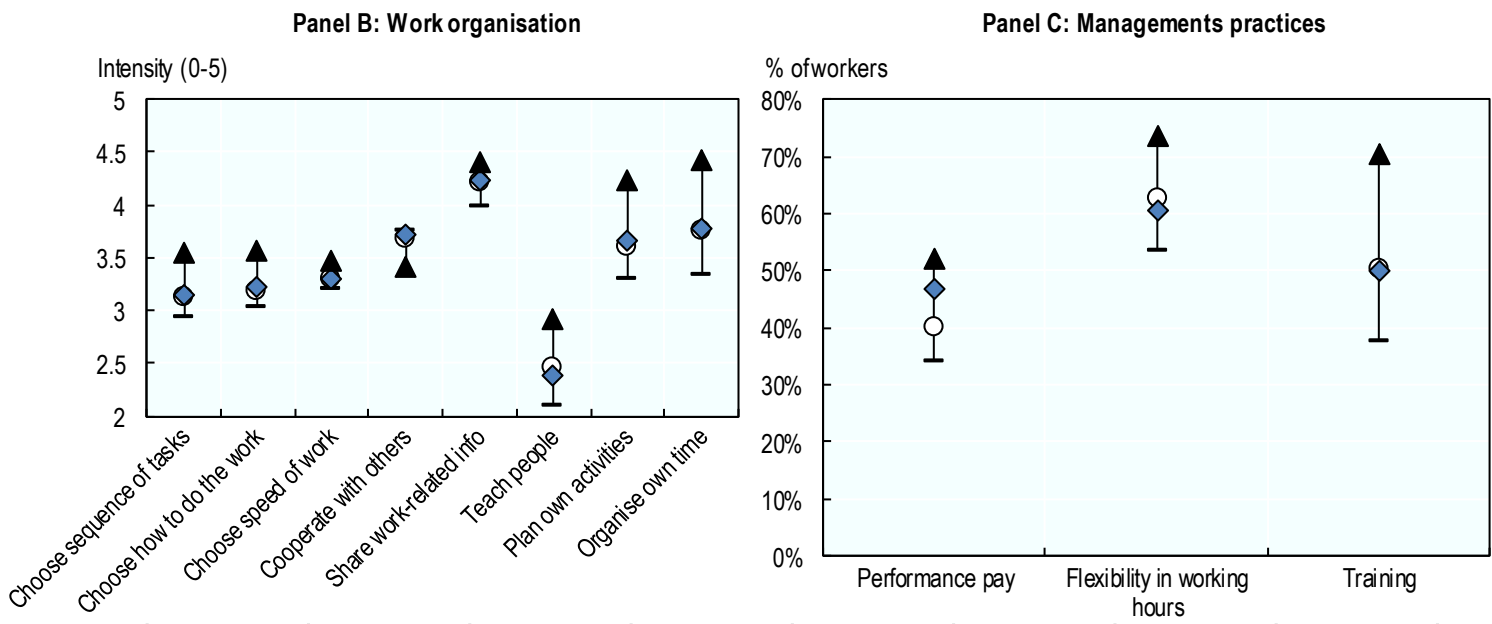

Note: Includes employed individuals aged 16 to 34 not in formal education. Panels B and C show unweighted PIAAC averages. Belgium refers to Flanders only, the United Kingdom to England and Northern Ireland. Intensity in Panel B refers to the extent to which a worker can choose or change something (not at all, very little, to some extent, to a high extent, to a very high extent), or to the frequency of engaging in certain activities/carrying out certain tasks (never, less than once a month, less than once a week but at least once a month, at least once a week but not every day, every day).

Source: Authors' calculations based on the Survey of Adult Skills (2012, 2014, 2017).

The use of HPWP is important to foster better skill use. Different types of graduates might not only differ in the level of their skills (see chapter Chapter 3. ), but also in the intensity at which they use those skills. OECD $\left(2016_{[58]}\right)$ shows that countries rank differently in terms of skills proficiency and use, suggesting that these are indeed two different, albeit to some extent related, concepts. Higher skills use has been found to contribute to higher individual earnings and job satisfaction as well as, at the aggregate level, productivity growth (OECD, 2016[58]).

As Table 4.3 shows, VET graduates use their literacy, numeracy and problem-solving skills to the same extent at work than general education graduates with the same numeracy, literacy and problem-solving proficiency. This is true even within occupations and industries. Compared to tertiary education graduates employed in the same occupation and 
industry (and at similar proficiency levels), VET graduates use their skills significantly less intensively. By contrast, VET graduates use their skills more intensively than graduates without upper secondary education, and this is especially the case for literacy skills.

Table 4.3. Intensity of skill use, by education

Results from OLS regression

\begin{tabular}{|c|c|c|c|c|c|c|}
\hline & \multicolumn{2}{|c|}{ Literacy use } & \multicolumn{2}{|c|}{ Numeracy use } & \multicolumn{2}{|c|}{ Problem-solving use } \\
\hline & (i) & (ii) & (i) & (ii) & (i) & (ii) \\
\hline Below upper secondary (vs. VET) & $\begin{array}{r}-0.319^{* \star *} \\
(0.022)\end{array}$ & $\begin{array}{r}-0.211^{* * *} \\
(0.023)\end{array}$ & $\begin{array}{r}-0.144^{* * *} \\
(0.024)\end{array}$ & $\begin{array}{r}-0.084^{* \star *} \\
(0.024)\end{array}$ & $\begin{array}{r}-0.129^{* *} \\
(0.037)\end{array}$ & $\begin{array}{r}-0.087^{\text {** }} \\
(0.037)\end{array}$ \\
\hline General (vs. VET) & $\begin{array}{l}-0.018 \\
(0.019)\end{array}$ & $\begin{array}{r}-0.029 \\
(0.019)\end{array}$ & $\begin{array}{r}0.037 \\
(0.023)\end{array}$ & $\begin{array}{r}0.014 \\
(0.022)\end{array}$ & $\begin{array}{r}0.035 \\
(0.029)\end{array}$ & $\begin{array}{l}-0.046 \\
(0.028)\end{array}$ \\
\hline Tertiary (vs. VET) & $\begin{array}{r}0.519^{\star * *} \\
(0.015)\end{array}$ & $\begin{array}{r}0.193^{* * *} \\
(0.016)\end{array}$ & $\begin{array}{r}0.272^{\star \star *} \\
(0.019)\end{array}$ & $\begin{array}{r}0.180^{\star * \star} \\
(0.020)\end{array}$ & $\begin{array}{r}0.378^{* * *} \\
(0.022)\end{array}$ & $\begin{array}{r}0.165^{\star \star \star} \\
(0.024)\end{array}$ \\
\hline Occupation dummies & No & Yes & No & Yes & No & Yes \\
\hline Industry dummies & No & Yes & No & Yes & No & Yes \\
\hline Number of observations & 35772 & 31443 & 31215 & 27717 & 20784 & 18788 \\
\hline
\end{tabular}

Note: Unweighted Average of PIAAC countries. Includes employed individuals aged 16 to 34 not in formal education. All regressions include country fixed effects and controls for proficiency (literacy, numeracy and problem-solving, respectively), age, gender, migrant status and number of children. Occupations are included at the 2-digit level, industries at the 1-digitl level. The skill use variables are a combination of more detailed tasks (which are measured on a 1-5 scale), see OECD (2016[59]).

Source: Authors' calculations using the OECD Survey of Adult Skills $(2012,2014,2017)$.

Access to training is a very important part of effective HPWP. As shown in Figure 4.25, VET and general education graduates have similar participation rates in training, but these are much lower than the participation rate among tertiary education graduates. To ensure that adults' skills remain relevant for today's and tomorrow's labour market, access to up-skilling and re-skilling opportunities throughout the working life is crucial. Structural changes, such as technological progress, globalisation and population ageing, are all increasing the need for adult learning opportunities to ensure that adults have skills that correspond to the needs of the labour market (OECD, 2019 [60]).

When looking at participation in formal and non-formal job-related training by employed, unemployed and inactive adults (excluding those enrolled in formal education), the data show that VET graduates are slightly more likely to participate in training compared to general education graduates. ${ }^{24}$ Across PIAAC countries, $42 \%$ of VET graduates report to have participated in formal or non-formal job-related training in the past 12 months, compared to $38 \%$ of general education graduates. This is low compared to the participation rate of tertiary education graduates, which reaches $60 \%$ on average. Employed VET graduates and general education graduates have the same probability of participating at least once per week in informal learning at work, and this is only slightly lower than for tertiary education graduates: $76 \%$ of VET and general education graduates participate regularly in informal learning, compared to $82 \%$ of tertiary education graduates. Graduates

${ }^{24}$ The training component in the HPWP framework refers to participation in formal or non-formal training, irrespective of whether or not it is job-related, and only refers to employed adults. This is different from what is shown in Figure 4.25, which focuses on job-related training for all adults (irrespective of their labour market status). 
without an upper secondary education degree participate less in both forms of training than VET graduates, although the difference is small in the case of informal learning at work.

Figure 4.25. Participation in adult learning, by education

$$
\% \text { of graduates }
$$

Formal and non-formal job-related training

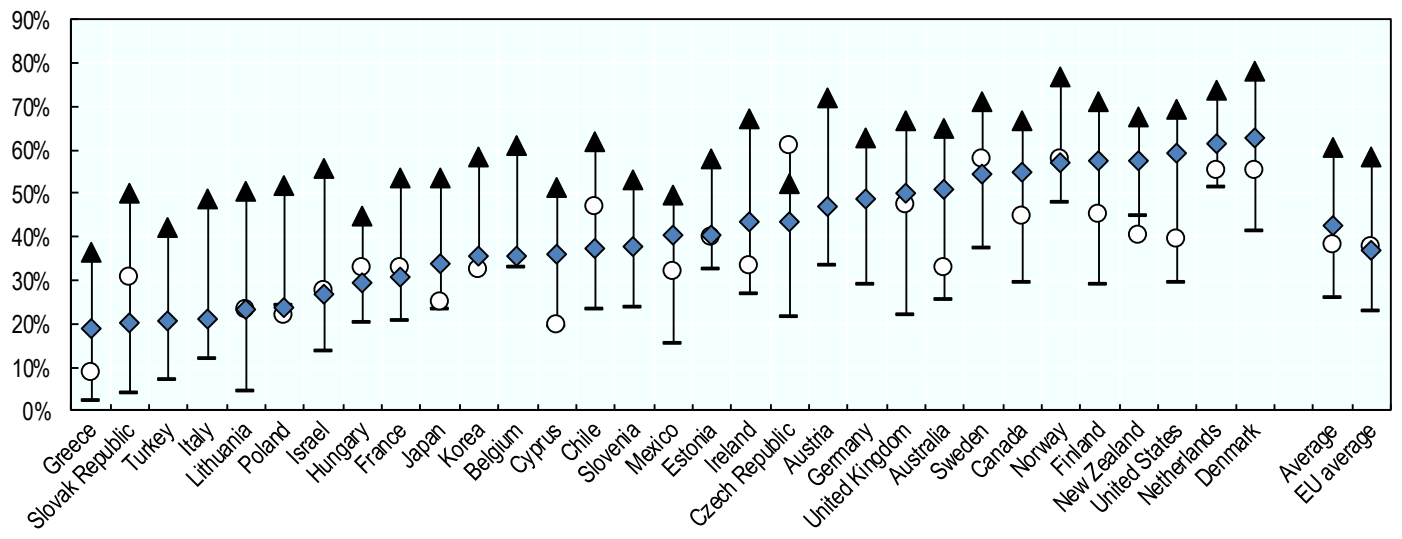

Informal learning

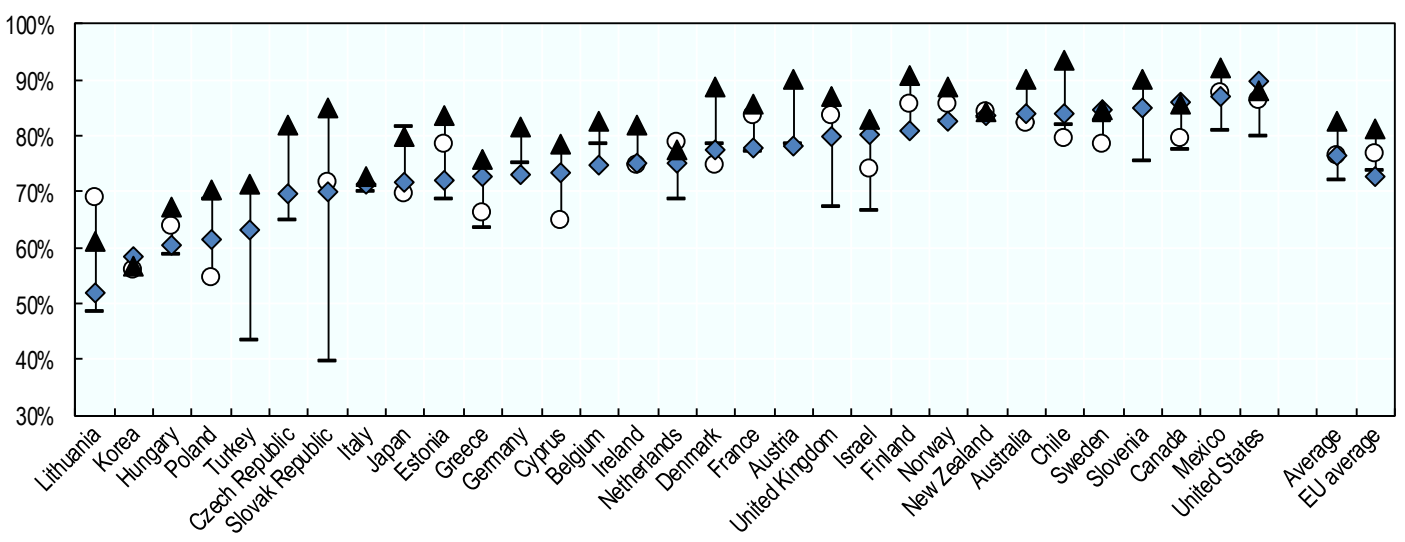

Note: Includes individuals aged 16 to 34 not in formal education (all adults in Panel A, employed only in Panel B). Participation in formal and non-formal training refers to the 12-month period before the interview. Participation in informal learning is defined as learning by doing, learning from others, or keeping up-to-date with new products or services at least once a week. Belgium refers to Flanders only, the United Kingdom to England and Northern Ireland

Source: Authors' calculations using the OECD Survey of Adult Skills (2012, 2014, 2017).

The similar participation rate in formal and non-formal training by general education graduates compared to VET graduates is also confirmed when controlling for personal characteristics, see Table 4.4. When comparing graduates in similar occupations and industries (i.e. adding occupation and industry controls), general education graduates are found to participate slightly less in formal and non-formal training than VET graduates. The difference in participation between VET and tertiary education graduates becomes smaller when comparing graduates in similar occupations, but remains statistically significant. Similarly, the gap between VET graduates and those who do not hold an upper secondary education degree is smaller when comparing individuals employed in similar 
occupations and industries, and even completely disappears in the case of informal learning.

Table 4.4. Probability of participating in training

Marginal effects from Probit regression

\begin{tabular}{|c|c|c|c|c|c|}
\hline & \multicolumn{3}{|c|}{ Formal and non-formal } & \multirow{2}{*}{\multicolumn{2}{|c|}{$\begin{array}{l}\text { Informal } \\
\text { Employed only }\end{array}$}} \\
\hline & \multirow[t]{2}{*}{ All } & \multicolumn{2}{|c|}{ Employed only } & & \\
\hline & & (i) & (ii) & (i) & (ii) \\
\hline $\begin{array}{l}\text { Below upper secondary (vs. } \\
\text { VET) }\end{array}$ & $\begin{array}{r}-0.108^{* \star *} \\
(0.009)\end{array}$ & $\begin{array}{r}-0.115^{\star \star \star} \\
(0.012)\end{array}$ & $\begin{array}{r}-0.072^{* * *} \\
(0.013)\end{array}$ & $\begin{array}{r}-0.044^{* * *} \\
(0.010)\end{array}$ & $\begin{array}{r}-0.014 \\
(0.011)\end{array}$ \\
\hline General (vs. VET) & $\begin{array}{l}-0.012 \\
(0.009)\end{array}$ & $\begin{array}{r}-0.019 \\
(0.012)\end{array}$ & $\begin{array}{r}-0.024^{* *} \\
(0.012)\end{array}$ & $\begin{array}{l}-0.007 \\
(0.010)\end{array}$ & $\begin{array}{l}-0.008 \\
(0.010)\end{array}$ \\
\hline Tertiary (vs. VET) & $\begin{array}{r}0.168^{* * *} \\
(0.007)\end{array}$ & $\begin{array}{r}0.165^{\star * *} \\
(0.009)\end{array}$ & $\begin{array}{r}0.067^{\star \star *} \\
(0.011)\end{array}$ & $\begin{array}{r}0.077^{* \star *} \\
(0.008)\end{array}$ & $\begin{array}{l}0.022^{* *} \\
(0.009)\end{array}$ \\
\hline Occupation controls & No & No & Yes & No & Yes \\
\hline Industry controls & No & No & Yes & No & Yes \\
\hline Number of observations & 43990 & 27896 & 27236 & 29685 & 28983 \\
\hline
\end{tabular}

Note: Includes individuals aged 16 to 34 not in formal education. Includes controls for age (15-19, 20-24, 25-29, 30-34), gender, number of children, migrant status, employment status (employed, unemployed, inactive), tenure at the employer (less than 2 years, 2 to 10 years, 11 to 20 years, more than 20 years), firm size (1 to 10 , 11 to 50,51 to 250,251 to 1000 , more than 1000), country. Tenure and firm size controls are not included in the "All" regressions. Informal learning only relates to employed individuals, so the "All" category does not apply. Standard errors are included in parenthesis. $* * * \mathrm{p}<0.01,{ }^{* *} \mathrm{p}<0.05,{ }^{*} \mathrm{p}<0.1$.

Source: Authors' calculations using the OECD Survey of Adult Skills (2012, 2014, 2017).

Adults face many barriers when it comes to participation in training opportunities, often related to lack of time or financial constraints. Moreover, many adults report not being interested in participating in training. Indeed, only $15.8 \%$ of VET graduates who did not participate in training reported having wanted to participate in training. This is lower than among general and, especially, tertiary education graduates ( $20.6 \%$ and $25 \%$, respectively), but also lower than among those without an upper secondary education degree (18.1\%).

For those VET graduates who did want to participate in (more) training ${ }^{25}$, the main reason for not doing so is because they are too busy at work (24.6\%), training is too expensive $(22.9 \%)$, and they have no time because of childcare responsibilities $(16.7 \%)$. The barriers faced by VET and general education graduates are very similar. Compared to tertiary education graduates, VET and general education graduates are less likely to say that they are too busy at work and more likely to find training too expensive or to be too busy because of family responsibilities. Graduates without an upper secondary education degree are less likely to report being busy at work or training being too expensive as barriers to training participation, while time constraints because of family responsibilities and lack of prerequisites are reported more frequently.

${ }^{25}$ This includes adults who did not participate in training but wanted to, and adults who participated in training and wanted to participate in even more training. 
Figure 4.26. Barriers to participation in formal and non-formal training, PIAAC average
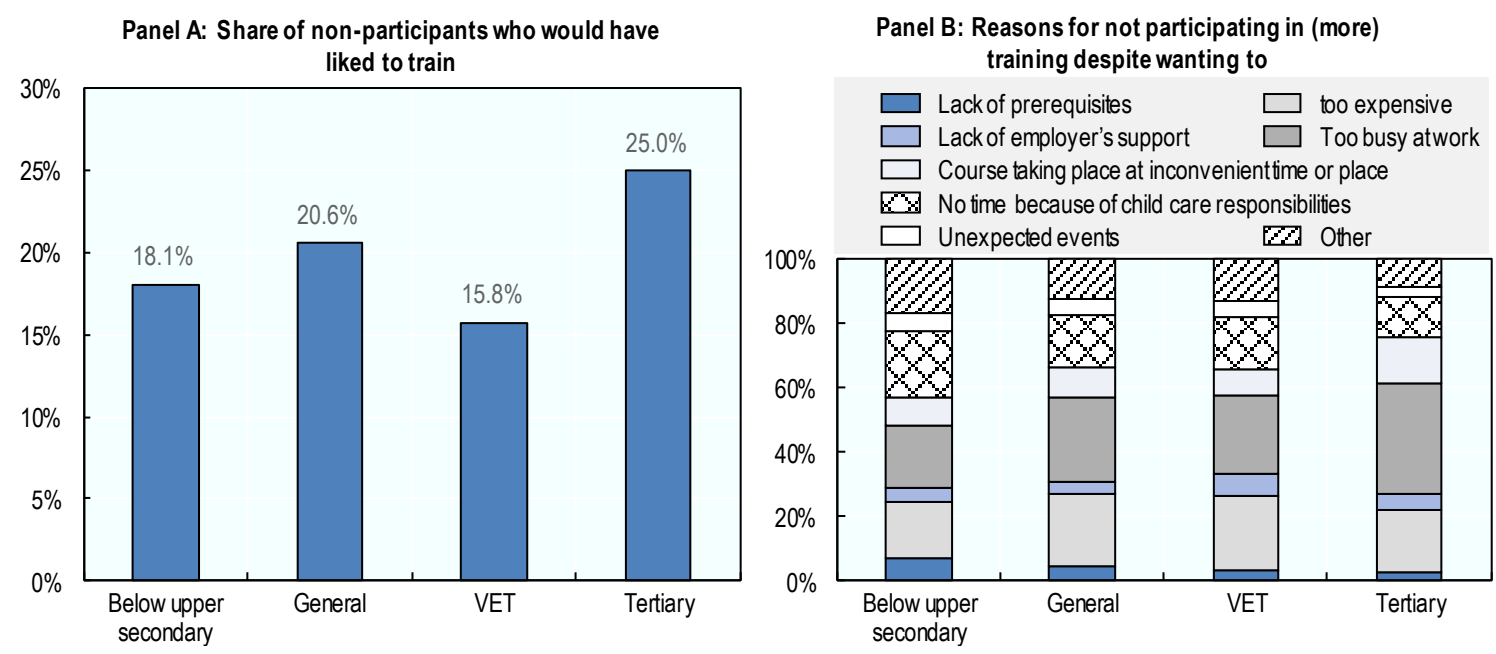

Note: Includes individuals aged 15 to 34 not in formal education. Panel A refers to all graduates who did not participate in training in the 12 months before the interview, Panel B to those graduates who reported wanting to participate in (more) training but not doing so. Both panels show the weighted PIAAC average. Source: Authors' calculations using the OECD Survey of Adult Skills $(2012,2014,2017)$.

Looking at trends in participation rates over the last decade, Adult Education Survey data show that there has been an increase in participation in formal and non-formal training in the period 2007-2016 for all education groups. The change was most outspoken for VET graduates, increasing from $37.6 \%$ in 2006 to $46.8 \%$ in 2016 across EU countries, and for graduates without an upper secondary degree (from $24.4 \%$ to $32.7 \%$ ). Growth was almost entirely driven by increased participation in non-formal training.

Figure 4.27. Trends in training participation, EU average

$\%$ of graduates participating in formal and non-formal training

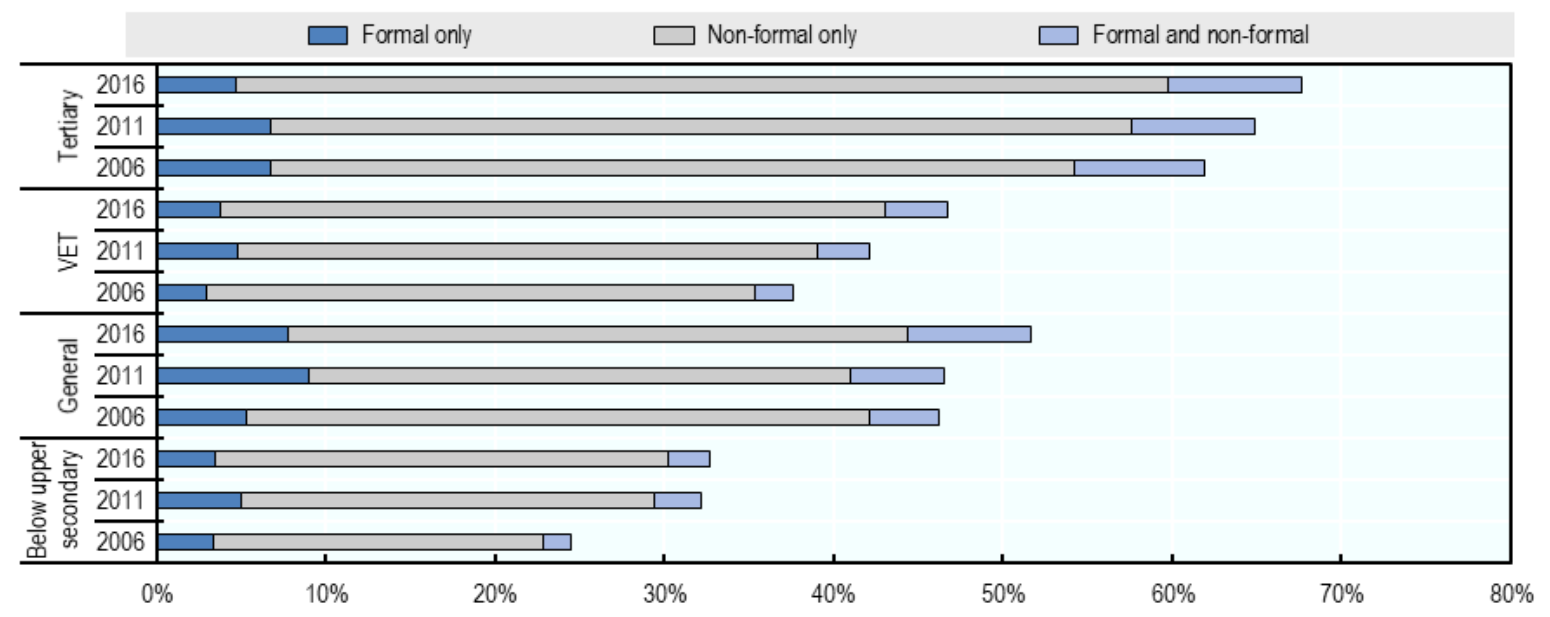

Note: Weighted average of countries included in all waves of AES. Refers to job-related and non-job related training in the 12 months before the interview, and includes all individuals aged 25-64 who obtained their highest qualification level at most 20 years ago and are currently not in education or training. Uses the vocational variable (hatvoc) in the 2016 AES (and in the 2011 AES for some countries), and derives the variables in the earlier years based on 2016 information on education level and field (in a similar vein as for EU-LFS data, see Box 2.1). 
Source: Authors' calculations using Adult Education Survey data (2006, 2011, 2016)

\subsection{Conclusion}

Consistent with earlier research, this chapter showed that VET graduates have higher employment rates and lower unemployment rates than general education graduates, confirming that VET appears to do a good job in preparing students for labour market entry. However, VET graduates who are unemployed are slightly more likely to stay unemployed for long periods. In countries like Austria. Denmark, Germany, the Netherlands, Sweden and Switzerland, VET graduates have high employment and low (long-term) unemployment rates, both from an international perspective and relative to other graduates in the country. In these countries, strong ties exist between the VET system and the world of work, which contributes to making the VET system responsive and therefore facilitates school-to-work transitions.

VET graduates are employed in fairly different jobs than general education graduates. The most important occupation groups for VET graduates are sales and service jobs and crafts and related trades jobs, both accounting for a quarter of VET graduates' employment. General education graduates are much less likely to work in crafts and related trade jobs, and a bit more likely to work in high-skill jobs. While on average only $19 \%$ of VET graduates work in high-skill jobs, this is the case for more than one third of all VET graduates in Malta, Germany and Switzerland. VET graduates are more likely than other graduates to be working in an occupation that matches their level of qualification. This could imply that VET systems do a better job in preparing students for specific roles in the labour market, but it could also mean that VET graduates have lower job mobility.

Although VET graduates have an advantage compared to general education graduates in terms of job quantity (i.e. employment rates), this does not seem to go hand in hand with higher job quality. VET graduates have similar hourly wages compared to general education graduates, and slightly higher wages when working in similar occupations and industries. Wages of VET graduates are substantially lower than those of tertiary education graduates, even when employed in similar jobs and having similar cognitive skills. In other areas of job quality, such as access to permanent contracts, exposure to high performance work practices and likelihood of having supervisory responsibilities at work, VET and general education graduates have similar outcomes. The only exception concerns frequency of carrying out physically demanding tasks, which is higher for VET than for general education graduates. While job quality generally increases with years since graduation for all education groups, the improvement seems to be slower for VET graduates than for general education graduates. In Denmark, Norway, Sweden and Switzerland, VET graduates score very high in several job quality dimensions, both relative to general education graduates and relative to VET graduates in other countries.

Access to training is an important aspect of a high-quality work environment, and is also crucial to ensure that adults can adapt to changing skill needs in the labour market. VET and general education graduates are roughly equally likely to participate in training, but much less likely to participate in training than tertiary education graduates. Nevertheless, training participation among VET graduates increased more strongly in the last 10 years than among other graduates. However, among graduates that did not participate in training, VET graduates are the least likely to say that they actually want to train. This could imply that VET graduates have limited awareness of the importance of training to adapt to changing skill needs. In countries like Denmark, the Netherlands, the United States, New Zealand and Norway, a relatively large share of VET graduates 
participate in training compared to other countries, and the gap between VET and tertiary education graduates' participation rates is relatively small. 


\section{Chapter 5. Has the labour market for vocational education graduates changed?}

Structural changes are affecting the skills needed in the labour market. Certain education levels and/or fields might be more or less in demand in the labour market because of these changes. This chapter looks at what happened to VET graduates in the last ten to fifteen year, mostly in terms of employment outcomes and types of jobs. It compares the changes faced by VET graduates to those of other graduates, to get a better understanding of the extent to which the different groups are gaining or losing because of structural changes.

\subsection{Trends in the composition of graduates}

\subsubsection{Tertiary education is on the rise}

The share of graduates from mid-level VET programmes decreased slightly across European countries in the period 2004-2017, from 38\% to 33\% (Figure 5.1). The share of graduates from tertiary education increased significantly (from $28 \%$ in 2004 to $37 \%$ in 2017), while the share of graduates from the lowest educational levels (i.e. below upper-secondary) decreased from 22\% in 2004 to $15 \%$ in 2017.

The average trend masks substantial differences between countries. In Portugal, where about 15 years ago VET was a very uncommon degree among 15-to-34 year-olds (less than $5 \%$ had at most a VET degree at the upper-secondary or post-secondary non-tertiary level), VET has become increasingly popular. The share of individuals with a VET degree also increased in Spain, Ireland, Finland and Italy. On the other hand, there are several countries where the share of middle-educated VET graduates has decreased substantially in the past 15 years (e.g. Slovak Republic, Poland, Switzerland, Hungary, Romania, Bulgaria, Denmark and Lithuania). This decline could be due to a falling popularity of VET versus general tracks in upper secondary (and/or post-secondary non-tertiary) education, but also to an increase in the share of VET graduates who continue to (and complete) tertiary education. 
Figure 5.1. Trend in the share of individuals by education
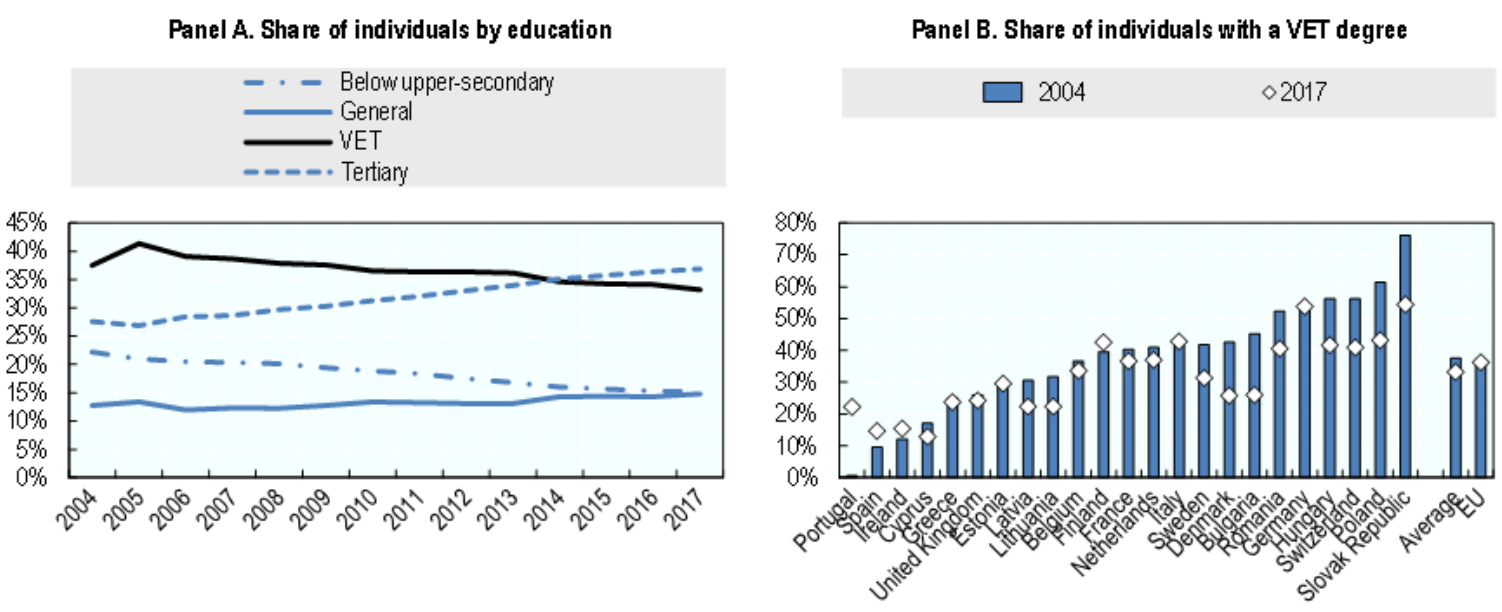

Note: Includes individuals aged 15 to 34 not in formal education. Panel A is based on a balanced panel of countries. In Cyprus (ISCED 3), France (ISCED 3), Malta (ISCED 3) and Sweden (ISCED 3 and 4), the fields of study are not detailed enough to clearly disentangle VET from general programmes prior to 2014. For these countries, this leads to a break in the time series of VET and general education graduates in 2014.

Source: Authors' calculations using EU-LFS data (2004-2017).

\subsubsection{Characteristics of VET graduates have changed significantly}

To put changes in labour market outcomes of VET graduates into perspective, it is important to analyse whether the characteristics of graduates have changed over time. Panel A of Figure 5.2 shows that 'Engineering, manufacturing and construction' has been the most common field of study for VET graduates since 2004, although the shares have been declining slightly since 2011 , from around $45 \%$ to $40 \%$ in 2017 . 'Social sciences, business and law' is also becoming a slightly less common field of study for VET graduates, which appears to be due to increasing shares of VET graduates who completed programmes in the fields of 'Services' and 'Health and welfare.'

The share of VET graduates with lower educated parents decreased substantially since 2004 (from $38 \%$ to $25 \%$ ), while the share with middle- or high-educated parents has increased (Figure 5.2, Panel B). Although the size of the change differs across European countries, the pattern tends to be similar. To some extent, this pattern might reflect a general trend of increasing qualification levels in European countries.

In most European countries, the share of women among VET graduates has decreased over the past 15 years (particularly in Latvia and Estonia; Figure 5.2, Panel C). However, it appears that countries with relatively high shares of women among VET graduates in 2004 (i.e. Ireland, the Netherlands, Germany and the United Kingdom), had similarly high shares of women in 2017. 
Figure 5.2. Trends in the characteristics of VET graduates
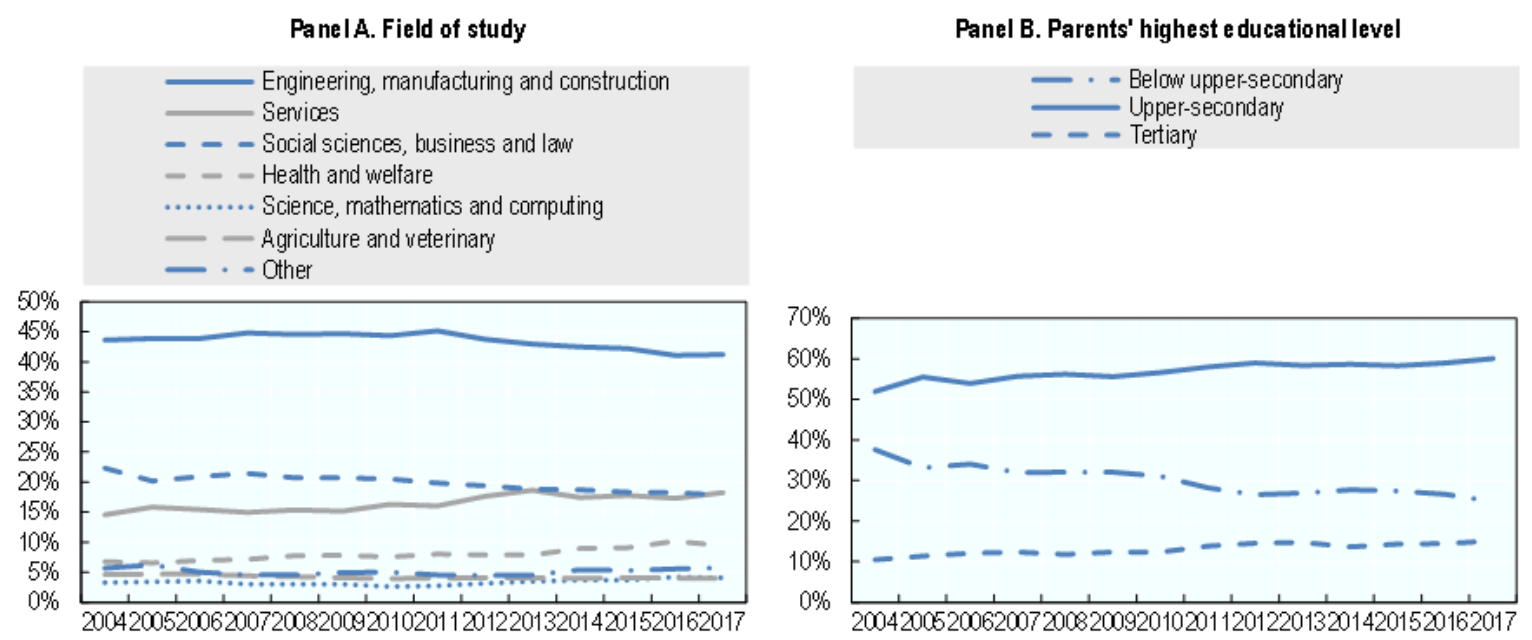

PanelC. Share of women

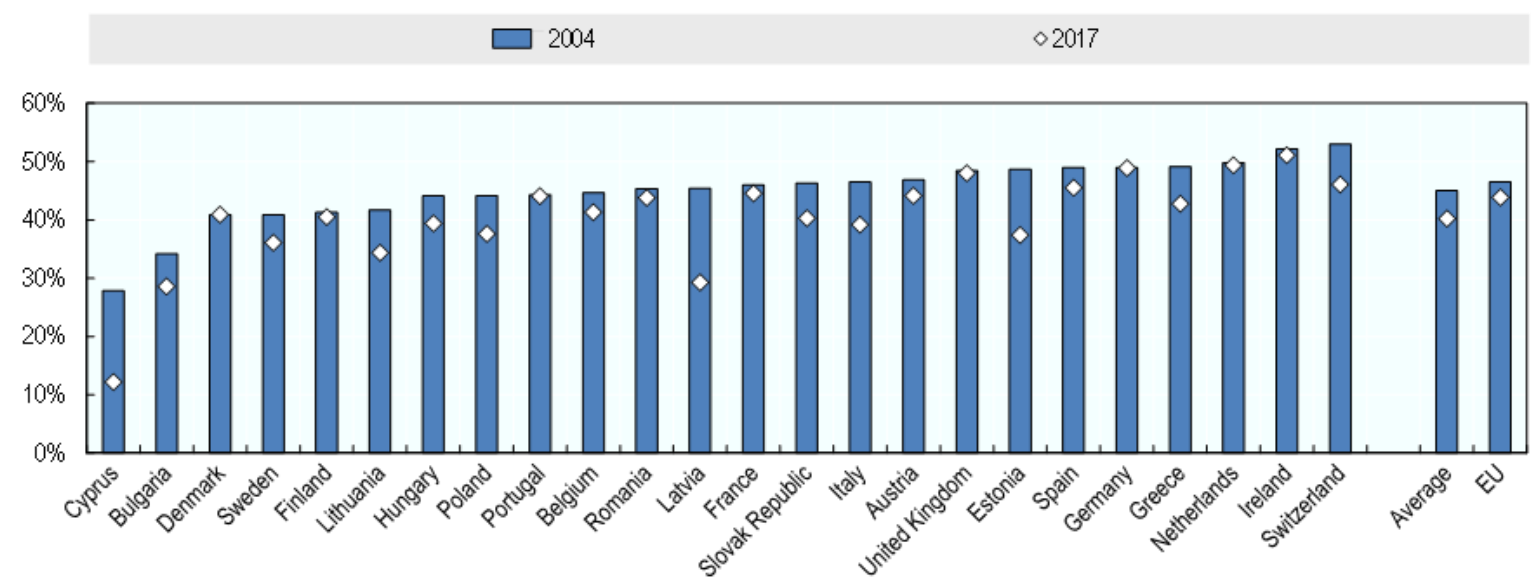

Note: Includes VET graduates aged 15 to 34 not in formal education. Based on a balanced sample of countries. In Cyprus (ISCED 3), France (ISCED 3), Malta (ISCED 3) and Sweden (ISCED 3 and 4), the fields of study are not detailed enough to clearly disentangle VET from general programmes prior to 2014. For these countries, this leads to a break in the time series of VET and general education graduates in 2014.

Source: Authors' calculations using EU-LFS data (2004-2017).

Table 5.1 summarises how personal characteristics of VET graduates relative to other groups of graduates have changed between 2004 and 2017. The results show that the share of women has not only decreased among VET graduates (as shown in Panel C of Figure 5.2), but also relative to graduates from general or tertiary education. The decrease in the share of women in VET was less pronounced than the decrease in the share of women among those without an upper-secondary degree. Considering that, overall, the share of VET graduates did not change much in the past 15 years (see Figure 5.1), it seems most likely that the reason for this 'increasing masculinity of VET' stems from both an increasing number of men and a decreasing number of women with a VET degree. ${ }^{26}$

${ }^{26}$ Potential reasons for this change include i) a decreasing number of women enrolling in VET in order to follow general upper-secondary education instead, ii) an increasing number of women 
Table 5.1. Determinants of VET status in 2004 and 2017

Marginal effects after logistic regressions

\begin{tabular}{|c|c|c|c|c|c|c|}
\hline & $(1)$ & $(2)$ & (3) & (4) & (5) & (6) \\
\hline & \multicolumn{2}{|c|}{$\begin{array}{l}\text { VET vs. } \\
\text { Below upper- } \\
\text { secondary }\end{array}$} & \multicolumn{2}{|c|}{$\begin{array}{l}\text { VET vs. } \\
\text { General }\end{array}$} & \multicolumn{2}{|c|}{$\begin{array}{l}\text { VET vs. } \\
\text { Tertiary }\end{array}$} \\
\hline & 2004 & 2017 & 2004 & 2017 & 2004 & 2017 \\
\hline \multirow[t]{2}{*}{ Gender (1=female) } & $0.028^{* * *}$ & $0.035^{\star * *}$ & $-0.023^{* * *}$ & $-0.056^{* * *}$ & $-0.074^{* * *}$ & $-0.129^{* \star *}$ \\
\hline & $(0.003)$ & $(0.003)$ & $(0.002)$ & $(0.005)$ & $(0.004)$ & $(0.014)$ \\
\hline \multicolumn{7}{|l|}{ Parents' highest obtained qualification } \\
\hline Below upper-secondary & Ref. & Ref. & Ref. & Ref. & Ref. & Ref. \\
\hline \multirow[t]{2}{*}{ Upper-secondary } & $0.184^{\star \star *}$ & $0.187^{\star \star *}$ & 0.003 & $-0.029^{\star \star *}$ & $-0.097^{\star \star *}$ & $-0.093^{* \star *}$ \\
\hline & $(0.011)$ & $(0.015)$ & $(0.006)$ & $(0.011)$ & $(0.008)$ & $(0.011)$ \\
\hline \multirow[t]{2}{*}{ Tertiary } & $0.197^{\star \star \star}$ & $0.190^{* * *}$ & $-0.089^{* * *}$ & $-0.159^{* * *}$ & $-0.341^{* * *}$ & $-0.365^{\star * *}$ \\
\hline & $(0.010)$ & $(0.008)$ & $(0.021)$ & $(0.010)$ & $(0.010)$ & $(0.012)$ \\
\hline \multirow{2}{*}{$\begin{array}{l}1 \text { st generation immigrant in current country of } \\
\text { residence }(1=\text { yes) }\end{array}$} & $-0.135^{\star \star *}$ & $-0.097^{\star * *}$ & $-0.081^{* * *}$ & -0.013 & $-0.105^{\star \star *}$ & -0.015 \\
\hline & $(0.010)$ & $(0.008)$ & $(0.018)$ & $(0.016)$ & $(0.015)$ & (0.011) \\
\hline \multicolumn{7}{|l|}{ Age } \\
\hline \multirow[t]{2}{*}{$15-19$ years old } & $-0.285^{\star \star \star}$ & $-0.272^{\star \star \star}$ & $-0.047^{* *}$ & $-0.150^{\star \star *}$ & $0.207^{\star \star \star}$ & $0.231^{\star \star \star}$ \\
\hline & $(0.024)$ & $(0.012)$ & $(0.018)$ & $(0.016)$ & $(0.007)$ & $(0.006)$ \\
\hline 20-24 years old & Ref. & Ref. & Ref. & Ref. & Ref. & Ref. \\
\hline \multirow[t]{2}{*}{ 25-29 years old } & $0.058^{* * *}$ & $0.029^{* * *}$ & 0.018 & $0.021^{* * *}$ & $-0.188^{\star * *}$ & $-0.193^{* * *}$ \\
\hline & $(0.004)$ & $(0.005)$ & $(0.011)$ & $(0.003)$ & $(0.003)$ & $(0.013)$ \\
\hline \multirow[t]{2}{*}{ 30-34 years old } & $0.070^{\star \star \star}$ & $0.036^{\star * *}$ & 0.018 & $0.022^{\star \star \star}$ & $-0.240^{\star \star *}$ & $-0.269^{* * *}$ \\
\hline & $(0.019)$ & $(0.006)$ & $(0.018)$ & $(0.006)$ & $(0.013)$ & $(0.008)$ \\
\hline \multicolumn{7}{|l|}{ Children } \\
\hline No own children & Ref. & Ref. & Ref. & Ref. & Ref. & Ref. \\
\hline \multirow[t]{2}{*}{ One child } & $-0.058^{\star \star \star}$ & $-0.052^{* * *}$ & $0.023^{\star \star *}$ & $0.032^{\star * *}$ & $0.137^{\star * *}$ & $0.146^{* \star *}$ \\
\hline & $(0.005)$ & $(0.005)$ & $(0.004)$ & $(0.007)$ & $(0.005)$ & $(0.009)$ \\
\hline \multirow[t]{2}{*}{ Two children or more } & $-0.148^{\star \star \star}$ & $-0.132^{* \star *}$ & 0.011 & $0.051^{* \star *}$ & $0.197^{\star \star \star}$ & $0.237^{\star \star *}$ \\
\hline & $(0.007)$ & $(0.012)$ & $(0.009)$ & $(0.008)$ & $(0.007)$ & $(0.013)$ \\
\hline Observations & 170611 & 238609 & 117308 & 214546 & 157221 & 292821 \\
\hline
\end{tabular}

Note: Results of six logistic regression analyses. Includes individuals aged 15 to 34 not in formal education The dependent variable is an indicator variable with value 1 if a person's highest obtained qualification is upper secondary VET, and 0 if the highest obtained qualification is below upper-secondary (columns 1 and 2), a general upper-secondary programme (columns 3 and 4) or a tertiary qualification (columns 5 and 6). The regressions includes fixed effects for the region of residence 1 year prior to the survey. The analyses are conducted on a balanced sample of countries. Robust standard errors, clustered at the regional level 1 year prior to the survey, are reported in parentheses, ${ }^{* * *} \mathrm{p}<0.01, * * \mathrm{p}<0.05,{ }^{*} \mathrm{p}<0.1$.

Source: Authors' calculations using EU-LFS data (2004, 2017).

(and/or a decreasing number of men) dropping out of VET before obtaining their degree, iii) an increasing number of women (and/or decreasing number of men) who complete tertiary education after having obtained their VET degree. It seems less likely that the change is due to an increasing number of men enrolling in VET instead of leaving education after completing lower-secondary education, because this would have more likely decreased (rather than increased) the difference in share of women between VET and below upper-secondary. 
The regression results also suggest that VET may have become relatively more inclusive for immigrants. Whereas 15 years ago the share of immigrants was (much) lower among VET graduates than among graduates from other educational groups, this difference has decreased significantly between 2004 and 2017. Finally, young adults with tertiary educated parents are less likely to obtain a VET degree than a general or tertiary degree, and this difference has increased over time. The change is particularly outspoken for VET versus general education. If parental education is a valid proxy for the abilities of individuals, this would indicate that the average abilities of VET graduates may have decreased compared to general education graduates, possibly due to changes in the selection into the vocational or general track. However, Box 5.1 shows some tentative evidence that the cognitive skill levels of VET graduates have stayed relatively stable over time, also in comparison to the skills of general education graduates.

\section{Box 5.1. Changing skill levels of graduates}

As educational attainment rates rise, one could expect the composition of graduates from different education groups to change, including their skill levels. Measuring these changes is not straightforward, as comparable information on the skill levels of graduates over time is not readily available. Using the OECD Survey of Adults Skills (PIAAC), one can compare graduates who obtained their degree in different time periods. The downside of such an analysis is that graduates who left the education system several years prior to the skill assessment carried out in the survey might have experienced skills depreciation or conversely- their skills might have further developed because of the activities they have engaged in after leaving education.

The figure below compares the skill level of different graduates at different times since graduation. This allows comparing the skill levels of those who graduated recently (i.e. less than 5 years ago) to those who obtained their degree 5 to 9 years ago and those who graduated 10 to 15 years ago. To eliminate as much as possible the differences related to skills depreciation and/or skills development after education, the skill levels reported in the figure are corrected for a range of aspects. These include: accumulated work experience, current employment status, current occupation, current industry, willingness to learn, 
participation in formal or non-formal training in the last 12 months, gender, migrant status and number of children.

Figure 5.3. Skill composition of graduates, by cohorts with different years since graduation
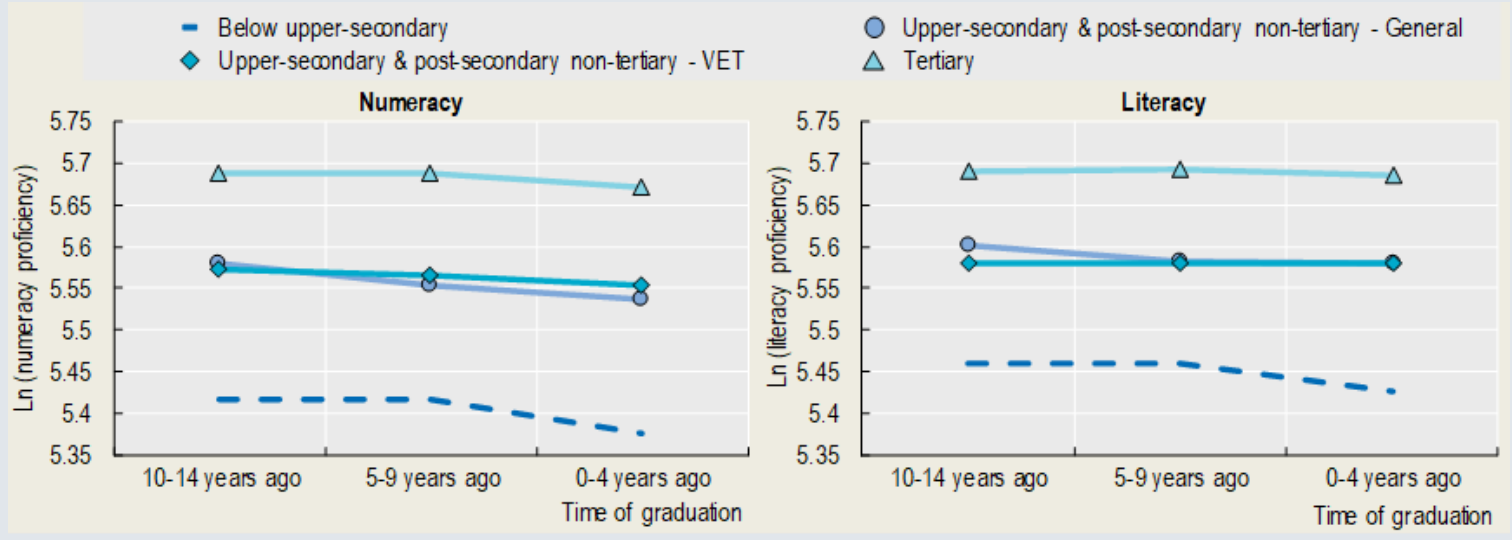

Note: Based on an OLS regression of skills (ln numeracy and literacy, respectively) on education group, years since graduation (+ an interaction of those two), labour market status, occupation (1-digit), industry (1-digit), years of work experience, willingness to learn, participation in formal or non-formal training, gender, migrant status, number of children, country (all included as dummy variables). Includes all individuals who are not enrolled in formal education and obtained their highest education qualification at most 15 years prior to the interview. The sample includes all OECD countries except Iceland, Latvia, Luxembourg and Portugal.

Source: OECD Survey of Adult Skills (2011/12, 2014/15, 2017/18)

The results show that the numeracy and literacy proficiency of recent graduates is slightly lower than that of adults who graduated between 5 and 15 years ago (with the exception of literacy skills of VET graduates). The decline is steeper for graduates who left education without an upper secondary education degree. Recent graduates from that group have lower literacy and numeracy skills than those who left education at least five years ago. The decline is also slightly stronger for general education graduates than for VET graduates, although differences are small. These results suggest that all graduates from a specific education level/orientation who left the education system at most 15 years ago entered the labour market with a broadly similar skillset, at least concerning general skills, with the exception of those without an upper secondary degree who now enter the labour market with lower skills than they did 5 to 15 years ago. Therefore, these results cautiously suggest that the relative skills of graduates leaving the education system in the past 15 years have remained roughly stable over time for VET, general and tertiary education graduates, and improved relative to those without an upper secondary degree.

\subsection{Trends in job quantity}

\subsubsection{The financial crisis decreased VET graduates' employment rates, but did not raise inactivity}

The evolution of employment rates are comparable between VET graduates and those with a general degree at a similar level. However, VET graduates experienced a sharper decline in employment rates in 2008/2009 than those with a tertiary qualification. Yet, VET graduates' decline in employment rates was not as large as for those without an 
upper-secondary degree. After controlling for graduates' characteristics,${ }^{27}$ the difference in the employment probabilities between vocational and other graduates are statistically significant in the entire 2004-2017 period.

Figure 5.4. Trends in the share of employed individuals, by education

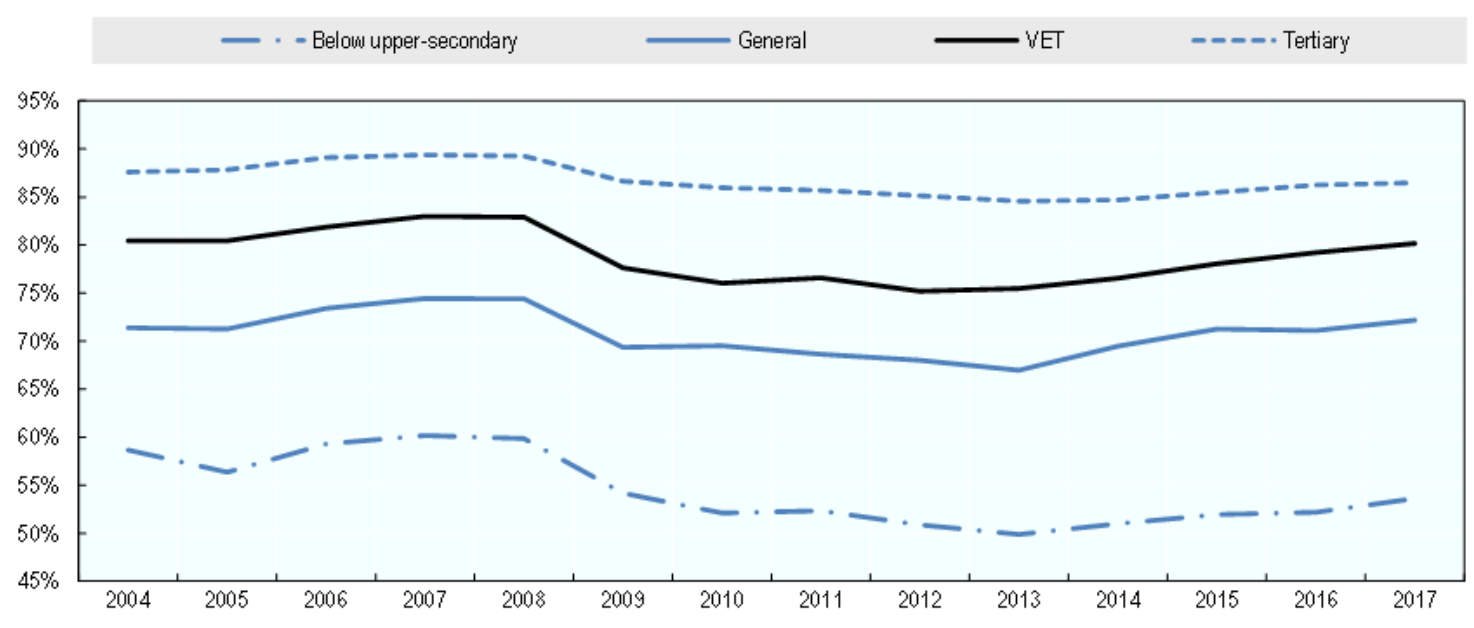

Note: Includes individuals aged 15 to 34 not in formal education. Based on a balanced panel of countries. Source: Authors' calculations using EU-LFS data (2004-2017).

In the past decade, VET graduates have continuously been significantly more likely to become NEET than graduates from general (or tertiary) education, and the financial crisis has only further increased the gap (Figure 5.5, Panel A). What is more, since 2009, VET graduates are even more likely to be NEET than those without an upper-secondary degree. However, the share of NEETs who are inactive and not in education (i.e., available but not actively looking for work and not in employment, education or training) decreased between 2008 and 2014, particularly among VET graduates. This indicates that, although VET graduates are increasingly likely to become NEET, this is driven by increasing unemployment rather than increasing inactivity among VET graduates.

27 Based on a regression analysis including gender, age, country of birth (foreign-born or not), number of own children, highest educational qualification of the parents, and current region of residence. 
Figure 5.5. Trends in the share of NEETs, by education

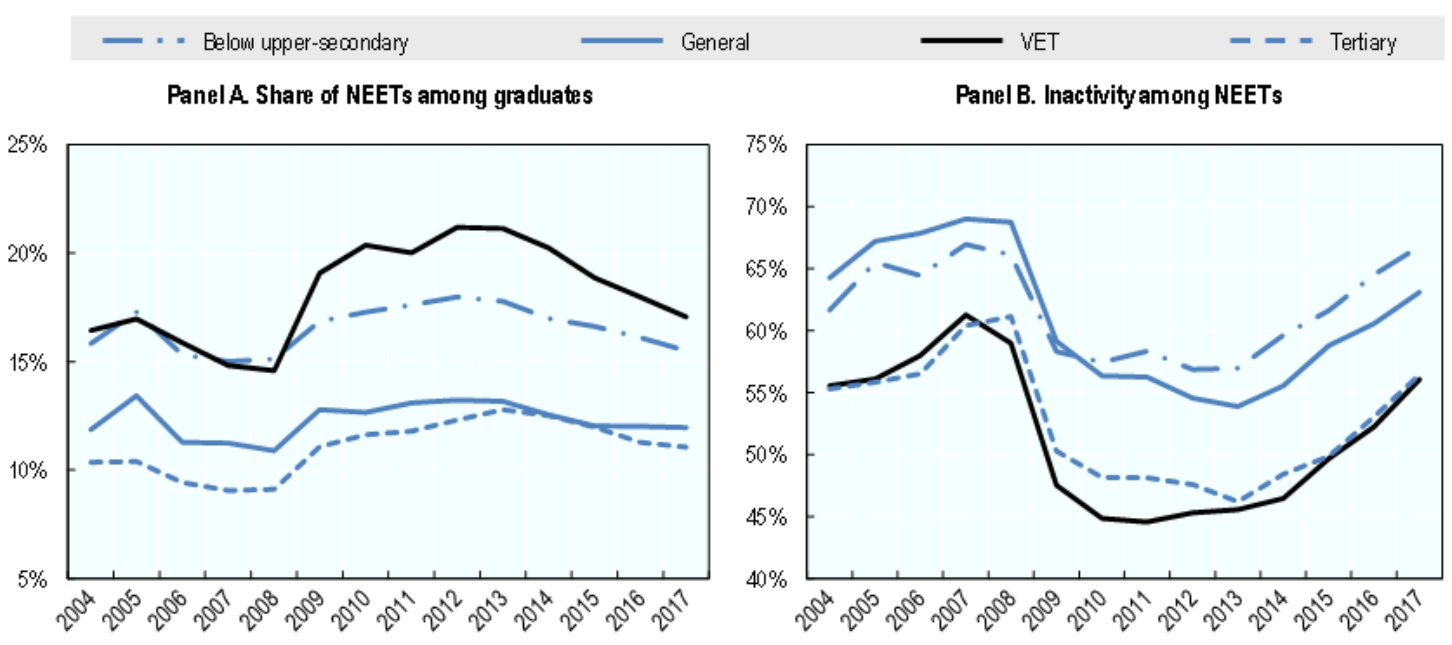

Note: Both graphs are based on a balanced panel of countries. Panel A includes all individuals aged 15 to 34 . Panel B includes individuals aged 15 to 34 who are not in employment, education or training (NEETs). Source: Authors' calculations using EU-LFS data (2004-2017).

For all graduates, long-term unemployment rates have increased since 2009, and the trend has been roughly the same for VET and general education graduates (Figure 5.6, Panel A). When controlling for graduates' characteristics, the difference in the probability to be long-term unemployed between vocational and general education graduates is not statistically significant in any year in the 2004-2017 period. The difference in long-term unemployment between VET graduates, tertiary education graduates and those without an upper-secondary qualification is statistically significant in all years. Panel B of Figure 5.6 shows that there are substantial differences in the change in the prevalence of long-term unemployment among VET graduates across European countries. For instance, in Poland and Estonia, long-term unemployment rates of VET graduates decreased substantially between 2005 and 2017, whereas they increased in other countries, particularly in Ireland. 
Figure 5.6. Trends in long-term unemployment
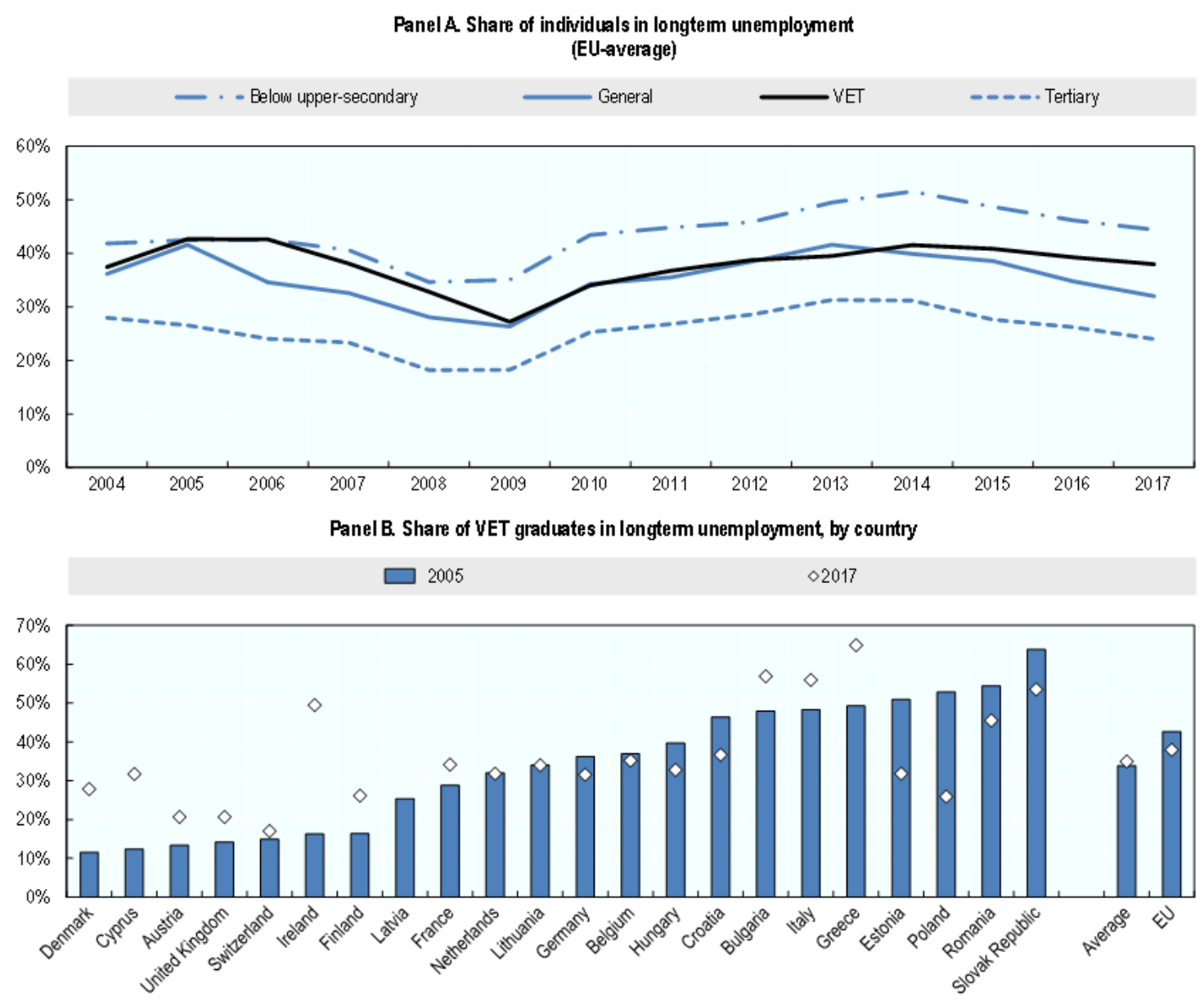

Note: Includes unemployed individuals aged 15 to 34. Panel A is based on a balanced panel of countries. In Cyprus (ISCED 3), France (ISCED 3), Malta (ISCED 3) and Sweden (ISCED 3 and 4), the fields of study are not detailed enough to clearly disentangle VET from general programmes prior to 2014. For these countries, this leads to a break in the time series of VET and general education graduates in 2014.

Source: EU-LFS (2004-2017)

\subsection{Trends in job types and job quality}

\subsubsection{The occupational composition of VET graduates' employment has undergone substantial changes}

The overall occupational composition of employment of 15-to-35 year-olds has changed in the past 15 years, broadly in line with the changes recorded in the overall labour market. While an increasing share of individuals aged 15 to 34 years old are employed in Services and sales jobs and as Professionals, the share working as a Craft and related trades workers is steadily decreasing since 2008 . 
Figure 5.7. Trend in employment by occupation group

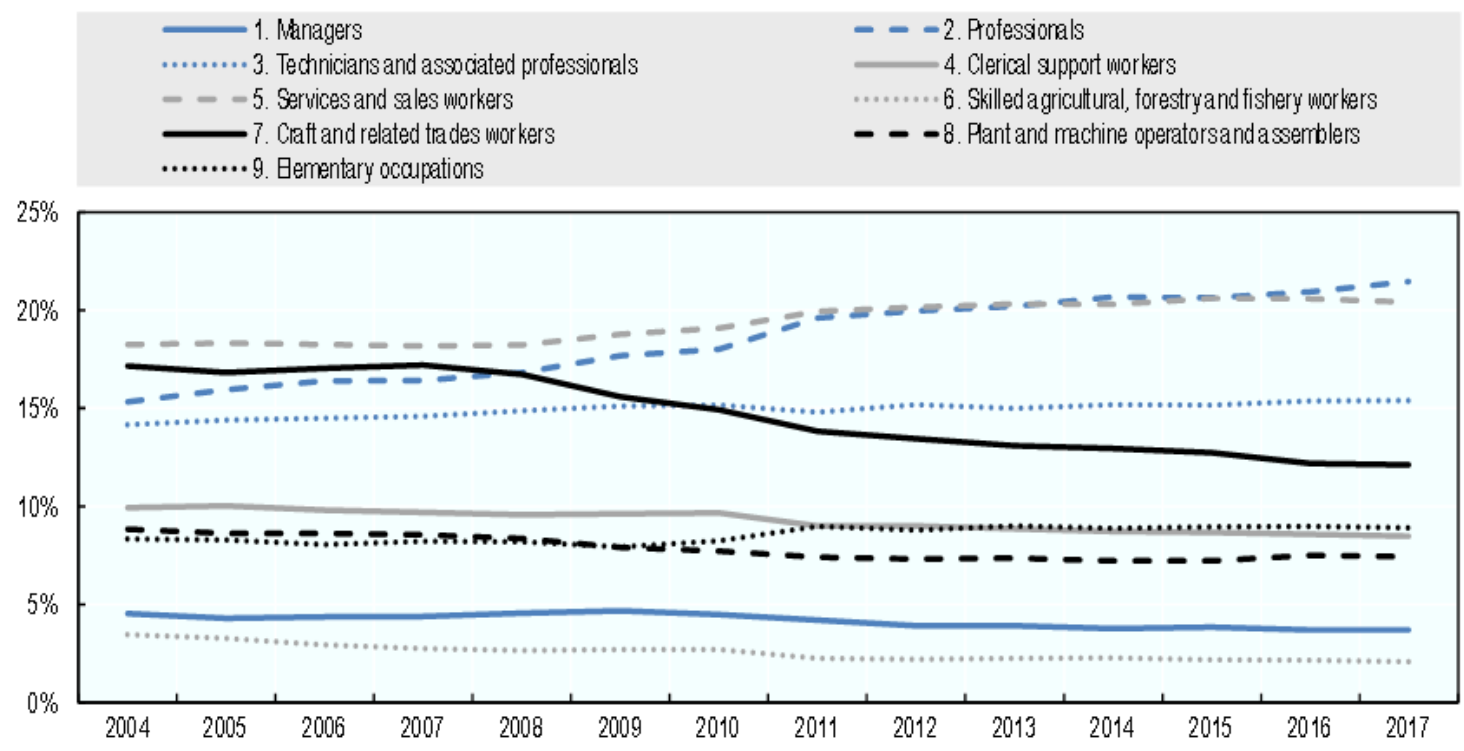

Note: Includes employed individuals aged 15 to 34 not in formal education. Based on a balanced sample of countries. In 2011, the ISCO occupational classification changed, leading to a break in the time series. To moderate the impact of the break, the ISCO-88 occupations are re-classified into ISCO-08 codes, based on the methodology proposed by (MacDonald, 2019[61]).

Source: Authors' calculations using EU-LFS (2004-2017).

Figure 5.8 shows the same trends in the occupational composition, but for graduates of the different education groups separately. It shows that general and vocational education graduates are increasingly employed as Service and sales workers, as are those without an upper-secondary degree, while a declining share of these graduates end up in clerical jobs. The growing overall importance of employment in Professional occupations (see Figure 5.7) seems to mainly benefit graduates from tertiary education: a large and relatively stable share of (a growing group of) higher educated graduates are employed as Professionals, while the share of VET and other graduates who work in this type of occupation is small and decreasing. Interestingly, while the share of lower, general and tertiary education graduates employed in Crafts and related trades occupations has been on the decline consistent with the overall trend (Figure 5.7) - the share of VET graduates employed in this occupation group remained relatively stable.

While on average, VET graduates are increasingly likely to be employed as Services and sales workers and decreasingly likely to work as Clerical support workers (see Panel C in Figure 5.8), this is not the case in all countries (see Figure 5.9). In Estonia, the Slovak Republic and Hungary, for example, the current share of VET graduates in services and sales occupations is similar to what it was around 15 years ago, and the share of VET graduates working in clerical jobs increased between 2004 and 2017. There are also important country difference in the change in the share of VET graduates who work as a Craft and related trades worker. While on average, this share has remained high and stable over the past 15 years, it has increased in some countries (particularly in Poland and Estonia), and decreased in others (for example Lithuania, Belgium and Germany). 
Figure 5.8. Occupations of graduates, by education

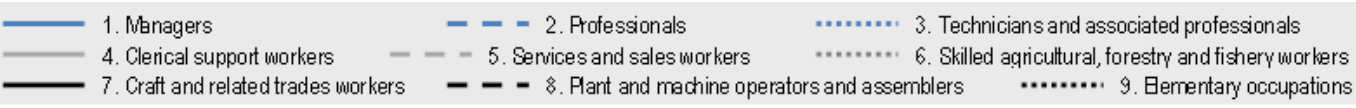

PanelA. Below upper-secondary

Panel B. General
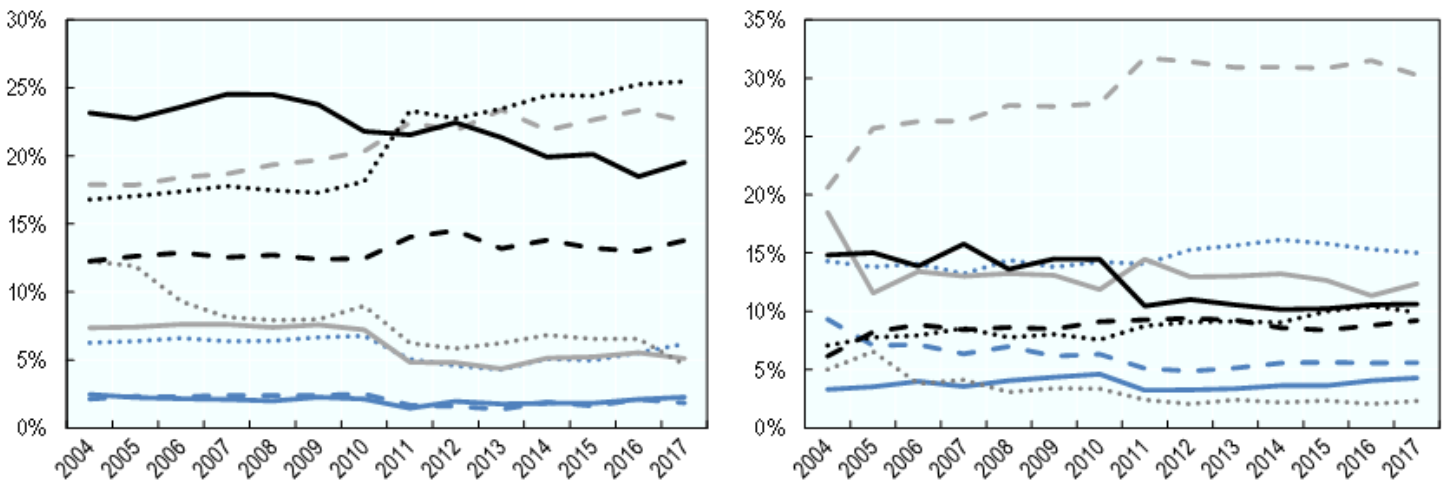

Panel C. VET

PanelD. Tertiary
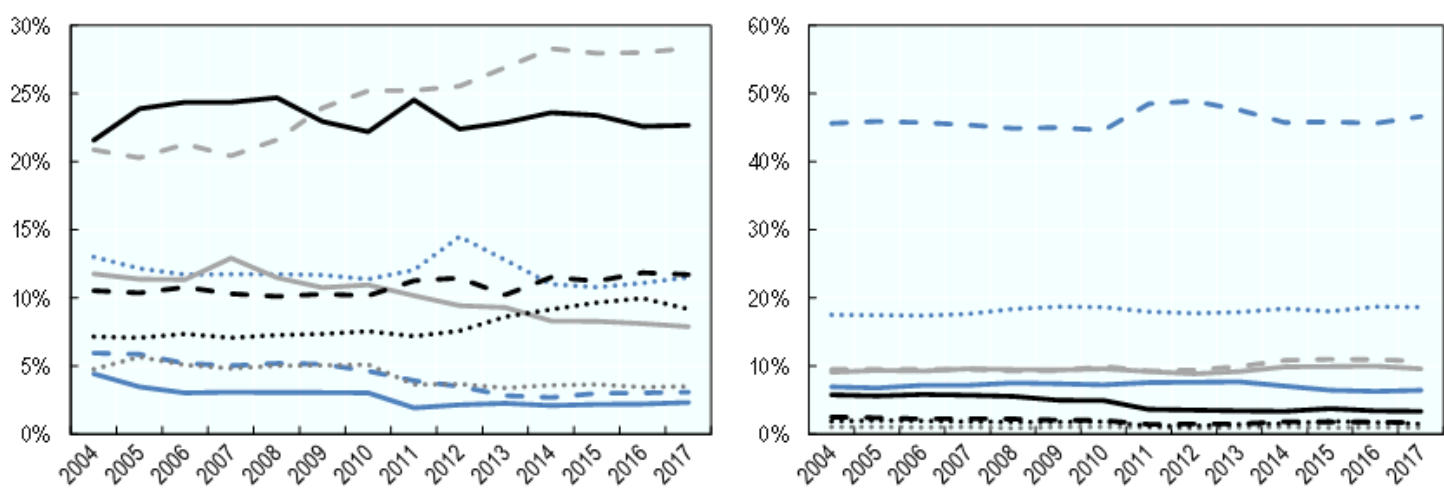

Note: Includes employed graduates aged 15 to 34 not in formal education. The ISCO- 88 occupations are re-classified into ISCO-08 codes, based on the methodology proposed by (MacDonald, 2019 [61]).

Source: Authors' calculations using EU-LFS (2004-2017).

It is also important to analyse country differences in the trend of VET graduates who work as Technicians and associate professionals, because these are generally high-wage occupations that are less likely to disappear due to automation. On average, the share of VET graduates who are employed as Technicians and associate professionals decreased slightly in the past 15 years (see Figure 5.8), and this is particularly the case in countries such as Italy, Portugal, Poland, Belgium, the Slovak Republic and Estonia. However, in some countries (i.e., Bulgaria, Latvia, Denmark, Switzerland and Germany), an increasing share of VET graduates are employed in this occupation group.

Finally, while the share of VET graduates who work in Elementary occupations (typically low-wage jobs) is relatively low, on average it has slightly increased between 2004 and 2017. This increase is particularly pronounced in Belgium, Greece, Poland, Italy and Portugal. 
Figure 5.9. Change in the share of VET graduates employed in selected occupation groups
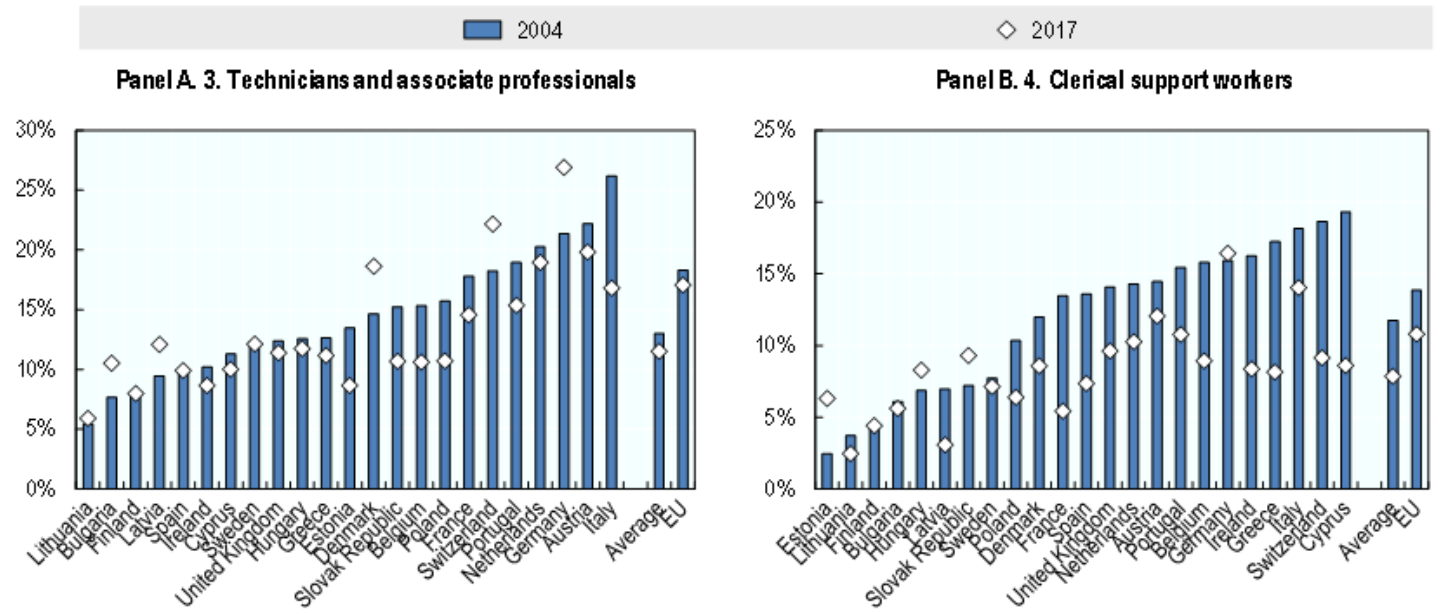

PaneI C. 5. Services and sales workers

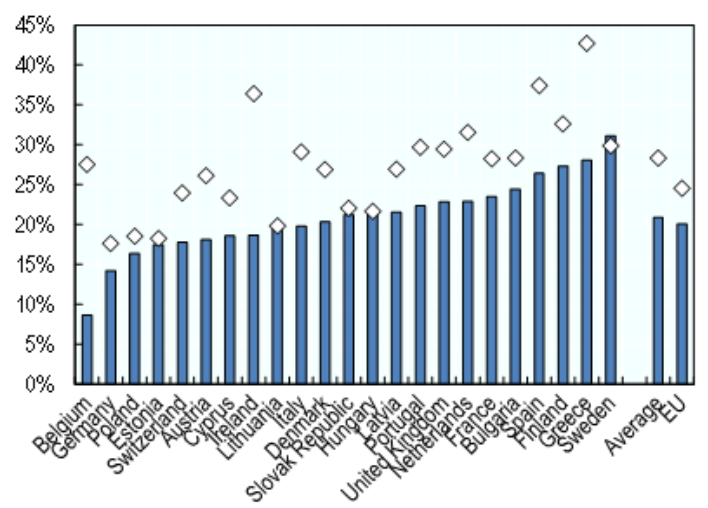

Panel D. 7. Craft and related trades workers

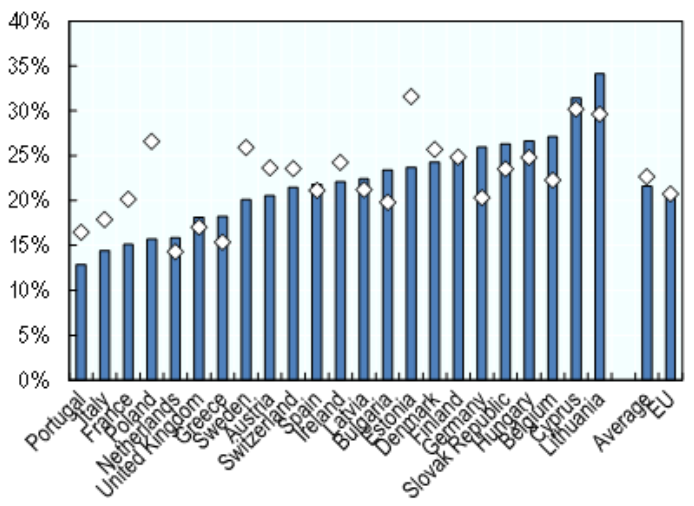

Panel E. 8. Plant and machine operators and assemblers

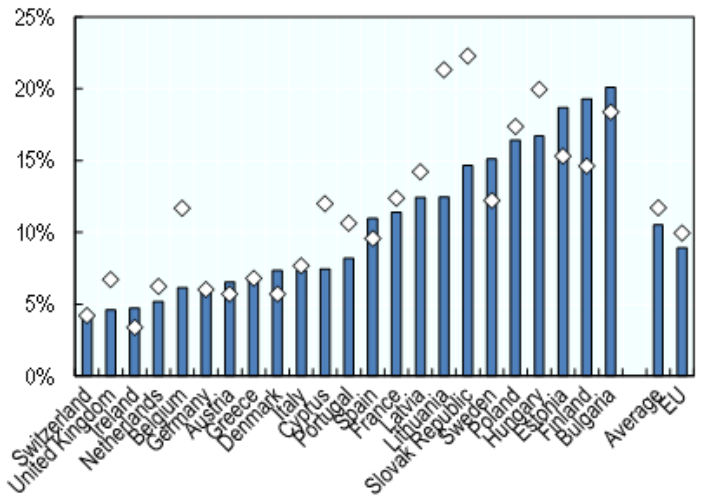

Panel F. 9. Elementary occupations

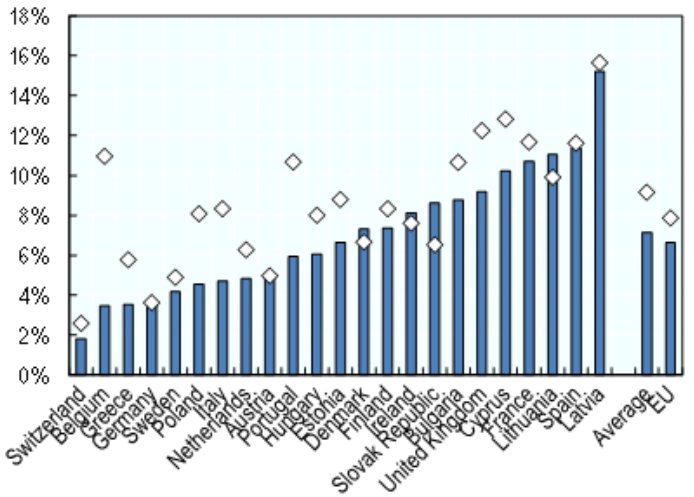

Note: Selection of the six occupation groups where most VET graduates work (see Figure 5.8, Panel C). Includes employed VET graduates aged 15 to 34 not in formal education. In Cyprus (ISCED 3), France (ISCED 3), Malta (ISCED 3) and Sweden (ISCED 3 and 4), the fields of study are not detailed enough to clearly disentangle VET from general programmes prior to 2014. For these countries, this leads to a break in the time series of VET and general education graduates in 2014. The ISCO-88 occupations are re-classified into ISCO-08 codes, based on the methodology proposed by (MacDonald, 2019[61]).

Source: Authors' calculations using EU-LFS (2004, 2017). 
Figure 5.10 shows the share of 15-to-34 year-old workers within an occupation, who have a vocational, general or tertiary education degree, or a degree below ISCED 3 (lower secondary education, primary education or below/no education). Within ISCO occupations 1 to 3 - typical high-wage / high-skill occupations (i.e., Managers, Professionals, Technicians and associate professionals) - as well as within Clerical support occupations (ISCO-4), the share of workers who have a VET degree has decreased in the past 15 years, while the share of workers with a general or tertiary education degree has increased. Although previous graphs have shown that VET graduates are increasingly likely to work in services and sales jobs (ISCO-5), the share of workers within this occupation with a VET degree has remained relatively stable over time. Within ISCO occupations 6 to 8 (i.e. Skilled agricultural, forestry and fishery workers, Craft and related trades workers and Plant and machine operators and assemblers), as well as in the Elementary occupations (ISCO-9), an increasing share of graduate workers have a VET degree.

\section{Figure 5.10. Share of VET graduates within each occupation}

EU-average

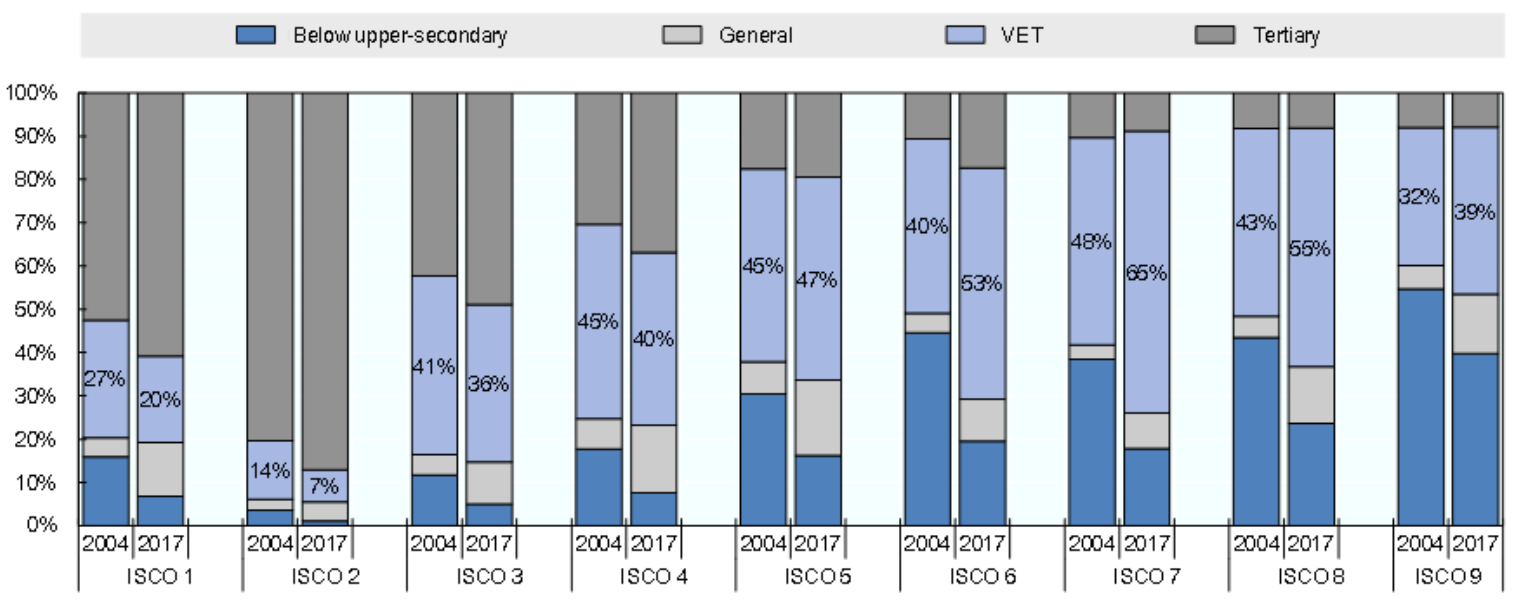

Note: Includes employed individuals aged 15 to 34 not in formal education. ISCO 1 are "Managers", ISCO 2 are "Professionals", ISCO 3 are "Technicians and Associate Professionals", ISCO 4 are "Clerical Support Workers", ISCO 5 are "Services and Sales Workers", ISCO 6 are "Skilled Agricultural, Forestry and Fishery Workers", ISCO 7 are "Craft and Related Trades Workers", ISCO 8 are "Plant and Machine Operators and Assemblers", ISCO 9 are "Elementary Occupations". The ISCO- 88 occupations are re-classified into ISCO-08 codes, based on the methodology proposed by (MacDonald, 2019[61]). Based on a balanced sample of countries. Source: Authors' calculations using EU-LFS (2004, 2017).

In order to disentangle the main components of the change in the occupational composition of VET graduates, Figure 5.11 summarises the evidence from the above figures. The change in the occupations where VET graduates are employed (see Panel C of Figure 5.8) is decomposed into: i) the change in overall graduate employment by occupation, i.e. the relative size of that occupation in the labour market for 15-to-34 year-olds (see Figure 5.7), and ii) the change in the share of VET graduates among 15-to-34 year-old workers within each occupation (see Figure 5.10). ${ }^{28}$

28 The decomposition also has a third component, i.e. the trend in the share of graduates that have a VET degree. This component is excluded from the graph, because it is very small (as can be seen in Figure 5.1). Moreover, it cannot explain much of the change in the occupations where VET 
Figure 5.11. Decomposition of the change in occupations where VET graduates find employment (EU-average)

Change between 2004 and 2017

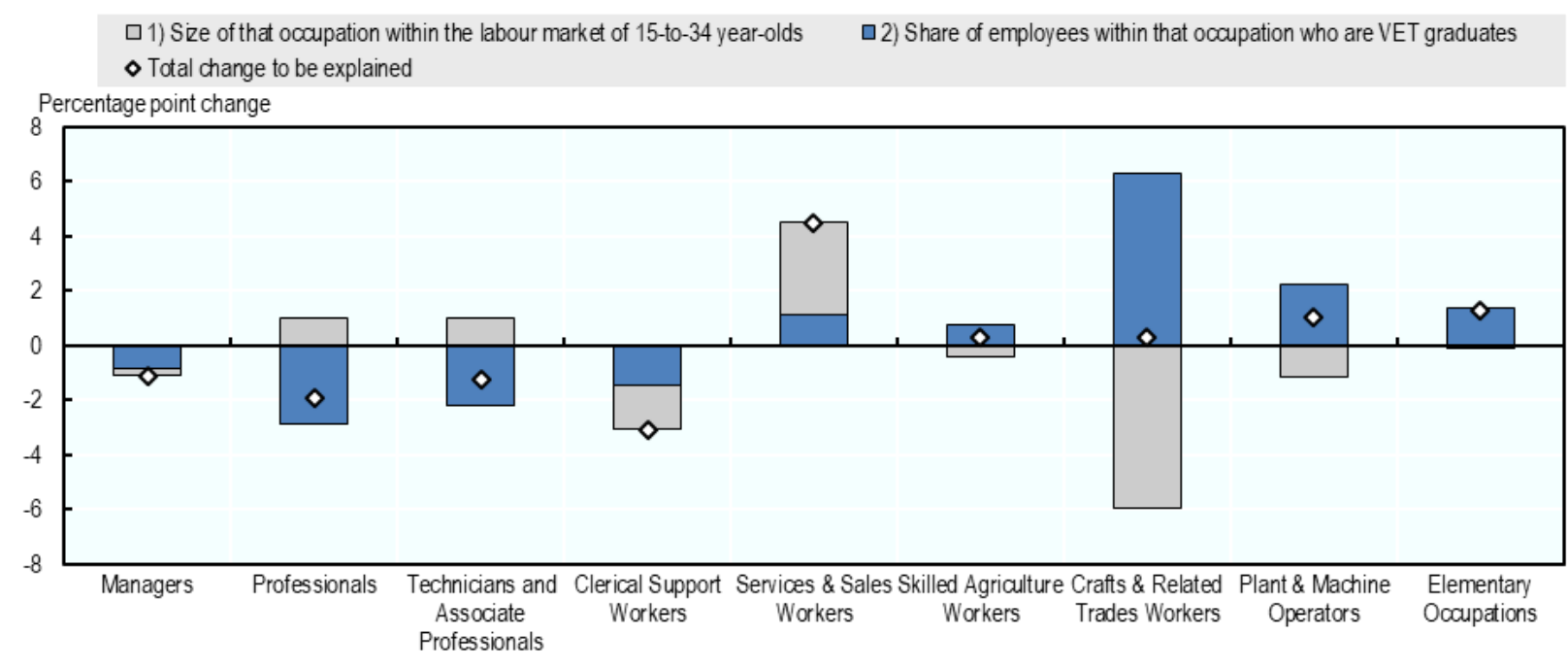

Note: Includes employed VET graduates aged 15 to 34 not in formal education. The ISCO- 88 occupations are re-classified into ISCO-08 codes, based on the methodology proposed by (MacDonald, 2019[61]).

Source: Authors' calculations using EU-LFS (2004, 2017).

The chart shows that the importance of craft and related trades jobs remained fairly stable for vocational education graduates (i.e. 'Total change to be explained', represented by the diamond shape) because of two countervailing effects: i) an overall decline in the importance of this occupation in total employment of 15-to-34 year-olds (grey bar), and ii) a rise in the share of VET graduates among graduates working in this occupation (blue bar). Another way to interpret the results for craft and related trades jobs is that, although total employment in this occupation is decreasing (grey bar), the share of VET graduates who find employment in this type of occupation is stable over time (diamond). Therefore, the share of VET graduates within craft and related trades occupations is increasing (blue bar). Another example are Services and Sales jobs, which have gained in importance for VET graduates, mostly because it is an occupation that is growing overall (relatively large grey bar), and -to a lesser extent- because VET graduates are making up a growing proportion of graduate employment in those occupations (blue bar).

Although Professionals - typically a high-wage and high-skill job - is a growing occupation in the labour market (grey bar), VET graduates are not able to benefit from this increase (diamond), as a decreasing share of these jobs are held by VET graduates (blue bar). Note that the counterintuitive observed decrease in employment in management occupations is specific to the labour market of 15-to-34 year-olds. Overall, employment in this type of jobs has remained relatively stable, but it is decreasingly slightly for 15-to-34 years olds ${ }^{29}$.

graduates find employment, because - by definition- its contribution to the change is identical across occupations.

29 The decline in employment for adults aged 15-34 in management occupations could partially reflect the series break in 2011 due to the introduction of the ISCO-08 classification. 


\subsubsection{The quality of jobs held by vocational and general education graduates has remained similar}

As discussed in chapter 4, VET and general education graduates on average have similar hourly wage levels (using EU-SILC data). Due to data limitations, it is not possible to conduct the same analysis over time. However, EU-LFS (2009-2017) can be used to analyse trends in the share of graduates who have monthly (take home) pay from their main job that is below median pay of all workers (i.e. across all age groups and all educational attainment levels). Figure 5.12. (Panel A) shows that, on average across European countries, the share of graduates with below-median monthly wages has remained fairly stable over time for all education groups. Moreover, the difference between VET and general education graduates has remained similar, even for those with similar jobs, hours worked and personal characteristics. ${ }^{30}$ The differences between VET graduates and those without an upper-secondary qualification or those with a tertiary education qualification, are statistically significant in all years.

Figure 5.12. Trend in the share of graduates who have below-median monthly (take home) pay from their main job

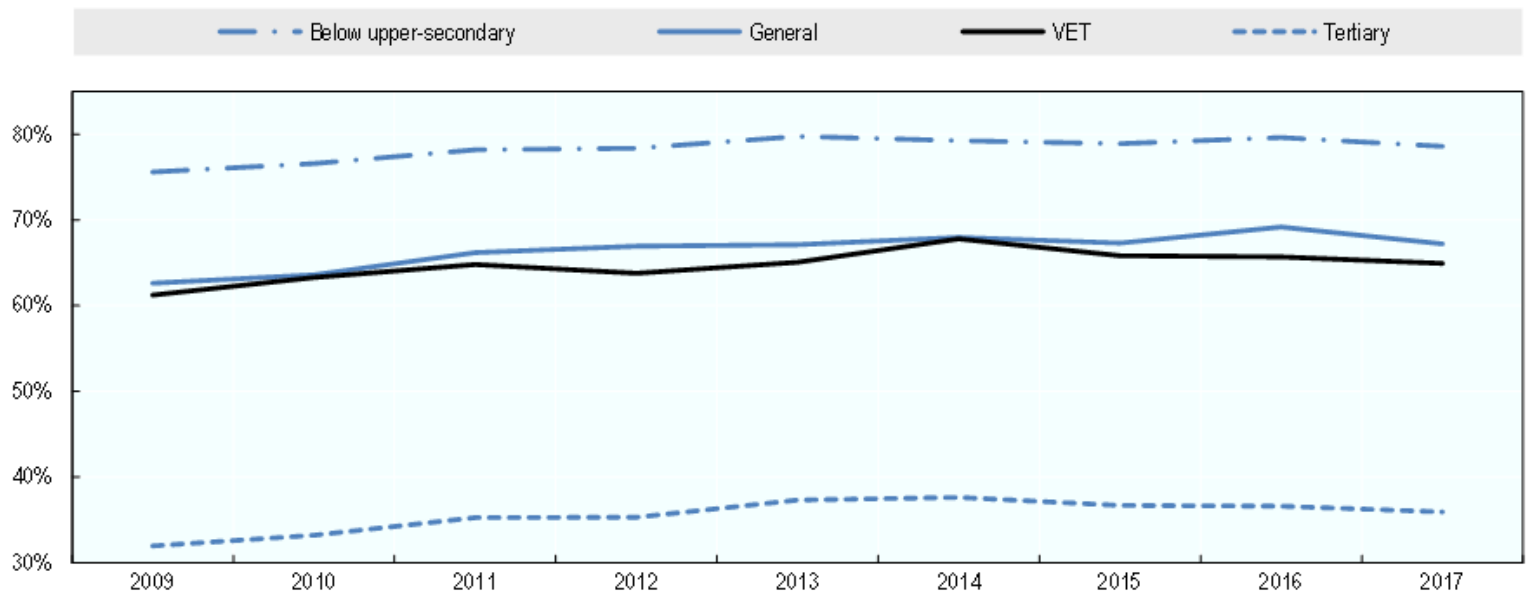

Note: Includes employed individuals aged 15 to 34 not in formal education. Based on a balanced sample of countries. In Cyprus (ISCED 3), France (ISCED 3), Malta (ISCED 3) and Sweden (ISCED 3 and 4), the fields of study are not detailed enough to clearly disentangle VET from general programmes prior to 2014. For these countries, this leads to a break in the time series of VET and general education graduates in 2014. Note that each country's median monthly (take home) pay is based on the full working population. It is therefore possible that more than $50 \%$ of 15 -to-34 year-olds have below-median wages.

Source: Authors' calculations using EU-LFS (2009-2017).

Temporary contracts have become increasingly common among graduates from all education groups, and the increase has been similar for VET and general education graduates. However, the increase has been slightly more pronounced for those without an upper-secondary degree than for VET graduates.

30 Job characteristics included in the regression are 2-digit occupation groups, contract type (temporary or permanent), firm size (4 categories) and hours worked. Personal characteristics included in the regression analysis are gender, age, country of birth (foreign-born or not), number of own children, highest educational qualification of the parents, and region of residence. 
Figure 5.13. Trend in the share of workers with a temporary contract, by education

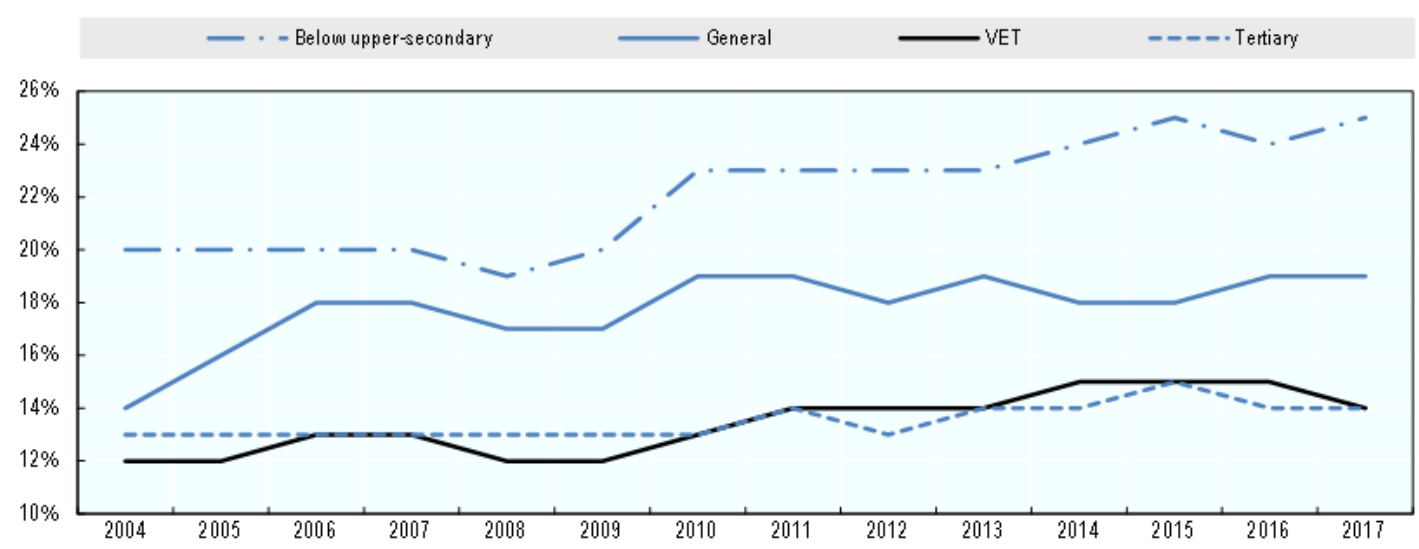

Note: Includes employed individuals aged 15 to 34 not in formal education. Based on a balanced sample of countries.

Source: Authors' calculations using EU-LFS (2004-2017).

As discussed in Chapter 4, VET graduates are more likely than general education graduates are to hold involuntary temporary contracts, i.e. indicating that the main reason for having a temporary job is that they were not able to find one with a permanent contract. Moreover, Figure 5.14 shows that, compared to graduates from general education, VET graduates experienced a larger increase in the share of involuntary temporary contracts, from $50 \%$ in 2005 to $58 \%$ in 2017.

Figure 5.14. Main reason for having a temporary job, 2004-2017

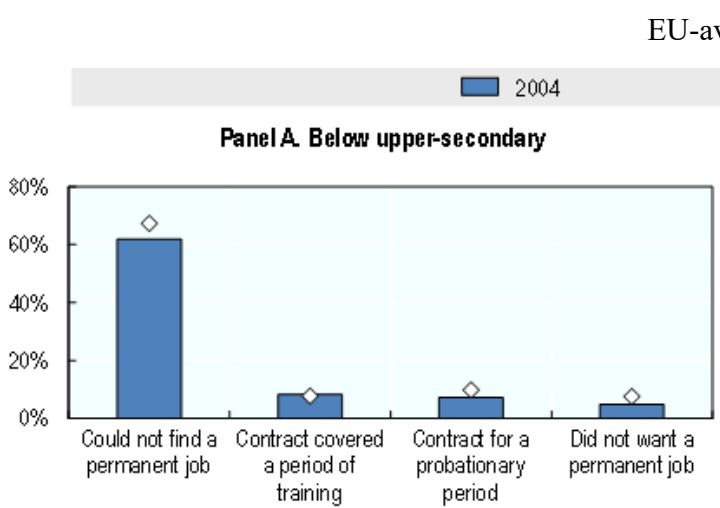

U-average

Panel C. VET

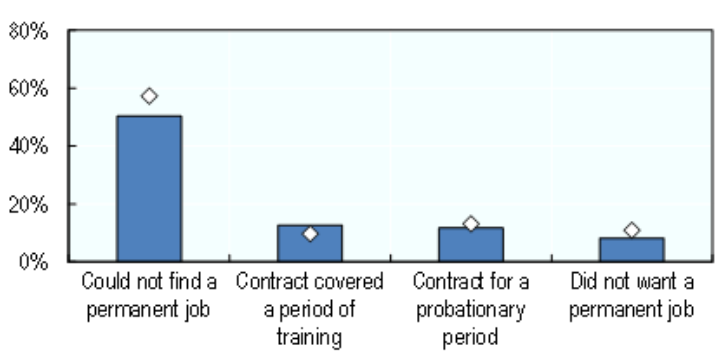

$\diamond 2017$

Panel B. General

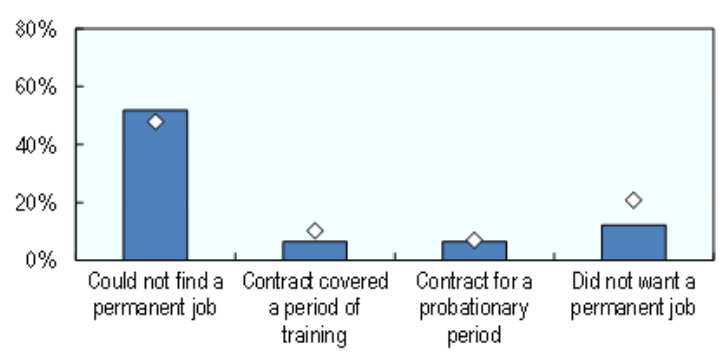

Panel D. Tertiany

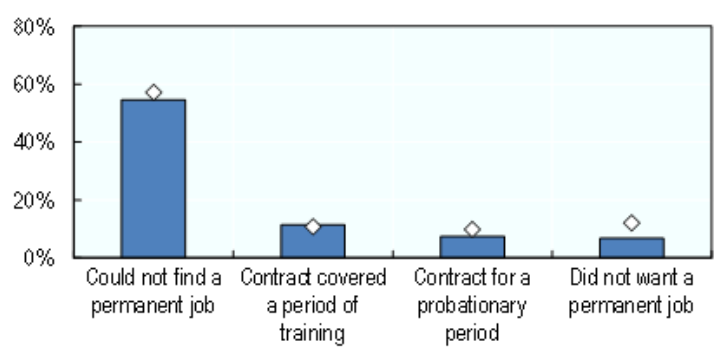

Note: Includes employed individuals aged 15 to 34 (not in formal education) with a temporary contract or work contract of limited duration. Each panel is based on a balanced sample of countries. 
Source: Authors' calculations using EU-LFS (2004, 2017).

In the past 15 years, the share of graduates whose usual workweek exceeds 50 hours has decreased. However, the difference between the share of VET graduates who usually have long workweeks and graduates from general or tertiary education has remained relatively stable, while the share of individuals without an upper-secondary degree who usually have long workweeks has decreased more sharply. As a result, VET graduates and those without an upper-secondary degree are now equally likely to experience job strain through long working hours.

Figure 5.15. Trend in the share of graduates that work more than 50 hours per week

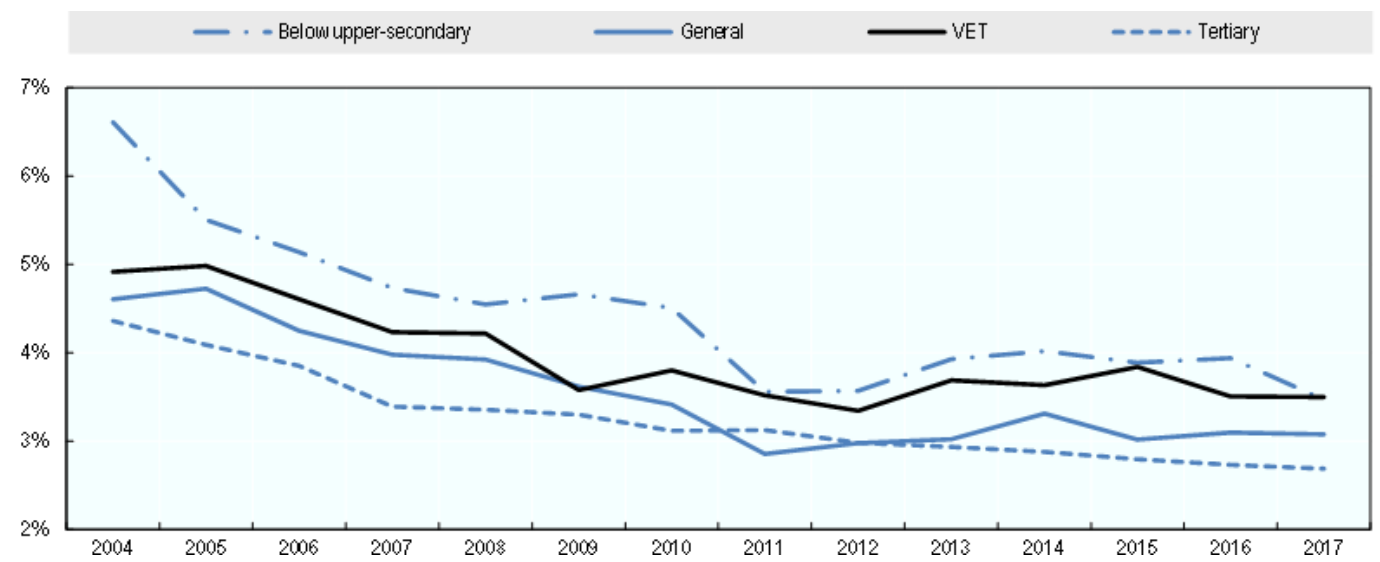

Note: Includes employed individuals aged 15 to 34 not in formal education. Based on a balanced sample of countries.

Source: Authors' calculations using EU-LFS (2004-2017).

As previously shown, VET graduates are equally likely as general education graduates to have supervisory responsibilities at work, particularly in the first years after graduation (see Figure 4.23). As shown in Figure 5.16, this has remained relatively stable over time. Although the share of tertiary education graduates with supervisory tasks has declined in the period 2006-2017, this appears not to be due to a shift of supervisory tasks from tertiary education graduates to graduates from other education groups (i.e. the share of other graduates with supervisory tasks did not increase). These results may imply that jobs with supervisory responsibilities are increasingly held by workers older than 35 . 
Figure 5.16. Trend in the share of graduates who are supervising others in their job

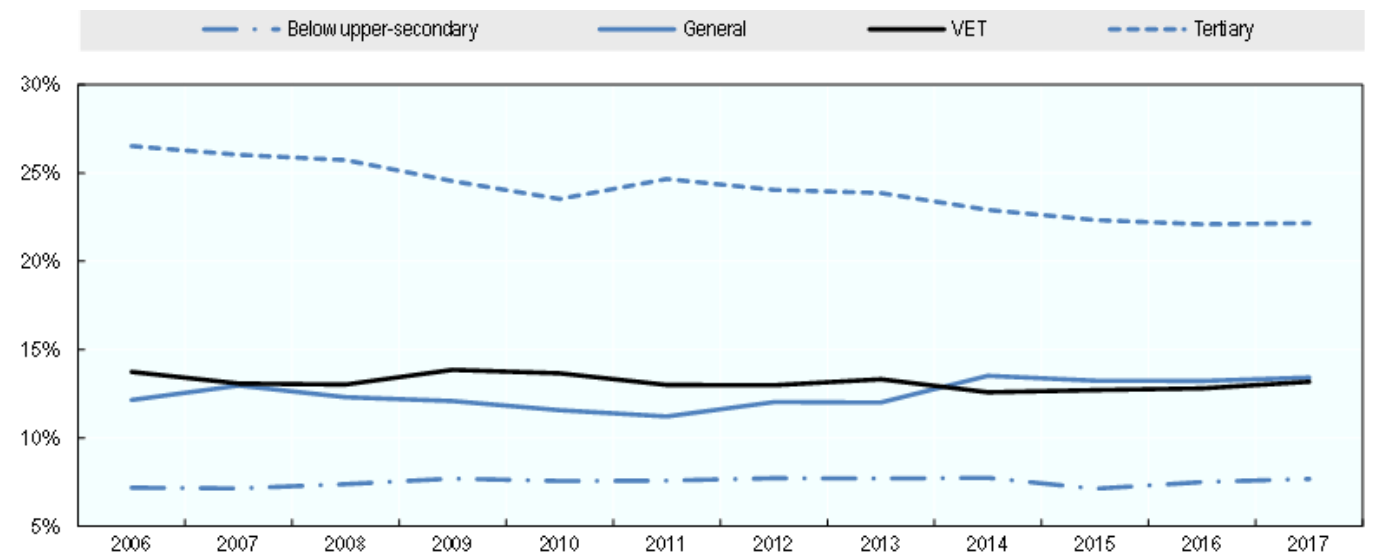

Note: Includes employed individuals aged 15 to 34 not in formal education. Based on a balanced sample of countries.

Source: Authors' calculations using EU-LFS (2006-2017).

\subsection{Conclusion}

The educational attainment of graduates has changed considerably in the last fifteen years, with strong growth in the share of graduates with tertiary education degrees and strong decline in the share of graduates without an upper secondary education degree. The share of graduates with a medium-level qualification remained fairly stable on average across countries, and within this group there was a marginal shift from VET towards general education. The specialisation areas of VET graduates have remained fairly stable on average across countries, with a modest shift away from technical fields towards services, health and welfare. In comparison to fifteen years ago, VET graduates today are, relative to general and tertiary education graduates, more likely to be male and less likely to have parents with at least upper secondary education.

Labour market outcomes in terms of employment and unemployment rates have remained relatively stable for VET graduates relative to other education groups. Similarly, the quality of jobs, measured as access to permanent contracts, incidence of long working hours, and probability of having supervisory responsibilities, has remained largely stable for VET relative to general education graduates. Both groups are now more likely to have a temporary contract and less likely to have long working hours compared to fifteen years ago.

The biggest changes can be observed for the types of jobs held by graduates. When looking at the occupational composition of employment of all graduates combined, the last fifteen years have seen strong growth in the share of professionals occupations, as well as sales and services occupations. By contrast, the employment share of craft and related trades occupations decreased considerably. The trends look fairly different when focussing on VET graduates (except for sales and services jobs, which are also growing in importance for VET graduates), for whom the share of professionals occupations declined modestly and the share of craft and related trades workers remained stable. The latter implies that VET graduates are securing the remaining crafts and related trades jobs, with now more than two thirds of workers in these occupations having at most an upper secondary or post-secondary non-tertiary VET degree. These trends also show that, despite of strong growth in high-skill occupations, these are not becoming more important in terms of 
employment share for VET graduates. However, in some countries, like Germany and Switzerland, a relatively large and growing share of VET graduates work as technicians and associate professionals.

These results suggest that VET has managed to maintain its comparative advantage relative to general education with regards to job quantity, also in a context of changing skills needs. However, changes in the occupational composition of employment imply substantial changes in the type of jobs held by graduates. For both VET and general education graduates, the importance of middle-skill jobs declined (consistent with the job polarisation pattern observed in the overall labour market). However, the change was substantially more outspoken for general education graduates, because VET graduates managed to secure the remaining jobs in crafts and related trades occupations. In line with the job polarization pattern, both VET and general education graduates are now more likely than fifteen years ago to be working as sales and service workers and in elementary occupations, which are generally considered as low-wage and/or low-skill jobs. The change was more outspoken for general education graduates than for VET graduates. At the same time, both groups have seen a decline in the relative importance of high-skill employment, despite substantial growth in the overall importance of those occupations. The latter is related to a growing supply of tertiary educated graduates.

Overall, even though VET graduates seem to be less strongly affected by these structural changes in the labour market than general education graduates, VET systems need to ensure that they are preparing students for jobs that are in demand in the labour market. In some countries, a substantial share of VET graduates are employed in high-skill jobs (mostly in associate professionals and technicians occupations), showing that medium-level VET can be a viable pathway to certain high-skill jobs. Moreover, what these data do not show is the extent to which initial VET graduates continue into further education as a way to access high-skill jobs. These pathways into further education might become increasingly important in a labour market that requires a lot of high-skilled professionals and with the expansion of higher VET programmes and with the expansion of higher VET programmes. 


\section{Chapter 6. Job mobility of vocational education graduates}

VET prepares students for the labour market, which should help smoothen the transition from school to work. However, as VET graduates specialised in certain fields or employed in certain occupations are facing declining demand for their skills, these graduates might face more instability in the labour market. They may need to change jobs or move into completely different occupations, and these transitions could come with periods of unemployment. This chapter uses panel data to analyse the mobility of VET graduates, both between jobs and occupations and between different labour market statuses.

\subsection{School-to-work transition}

\subsubsection{VET graduates transition more quickly into work after graduation than general education graduates}

It is often argued that one of the main benefits of VET is that it directly prepares students for the labour market, as such making the transition from school to work easier than for graduates from general programmes. Chapter Chapter 3. indeed showed that VET graduates have higher employment and lower unemployment rates than graduates from the general track at the same education level.

As a proxy of the smoothness of school-to-work transitions, Figure 6.1 shows the average time between obtaining one's highest education degree and the start of the first significant work experience. ${ }^{31}$ It is important to note that these data are not very recent, as they were collected in 2009 and refer to individuals who obtained their qualification in the period 2004-2009. The results in Panel A show that, on average across countries, VET graduates wait 7.5 months after the end of their studies before starting their first significant job. This is shorter than for general education graduates ( 8.9 months). However, in a few countries, like Romania, France and Finland, VET graduates have shorter transitions periods than general education graduates. On average, the school-to-work transition of VET and general education graduates is slower than for tertiary education graduates, who spend 6.3 months between finishing their studies and starting their first job. However, in some countries the gap is of similar duration for vocational and tertiary education graduates (e.g. Spain, Belgium, Lithuania, Denmark and the United Kingdom). In all countries with available data (except Romania), VET graduates have shorter spells between graduating and their first significant job than those who left education without an upper secondary education degree, and in many countries the differences are substantial.

Panel B shows that there are also substantial differences between VET and tertiary education graduates by field of study, with the average duration for VET graduates being lowest among those with services and health \& welfare specialisations. Tertiary education graduates have shorter spells between work and study than VET graduates specialised in the same field, and the difference is largest for graduates specialised in 'science,

${ }^{31}$ Significant work experience is identified as a job for pay or profit (as employee, self-employed or family worker) with a minimum duration of 3 months. Apprenticeships or unpaid traineeships, compulsory military or community service, and summer jobs are excluded. 
mathematics and computing', 'teacher training and education science', and 'engineering, manufacturing and construction'.

Figure 6.1. Average time between leaving education and starting first significant job (2004-2009)

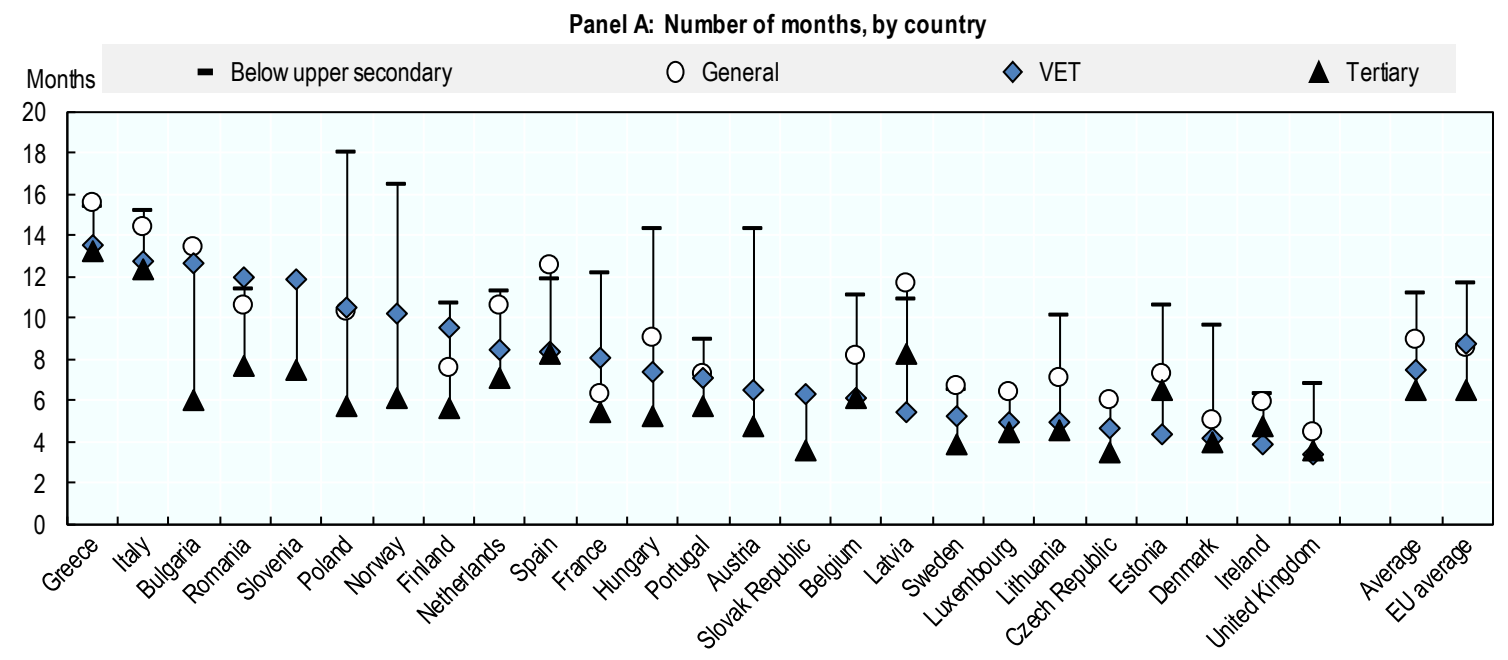

Panel B: Number of months, by field (EU-average)

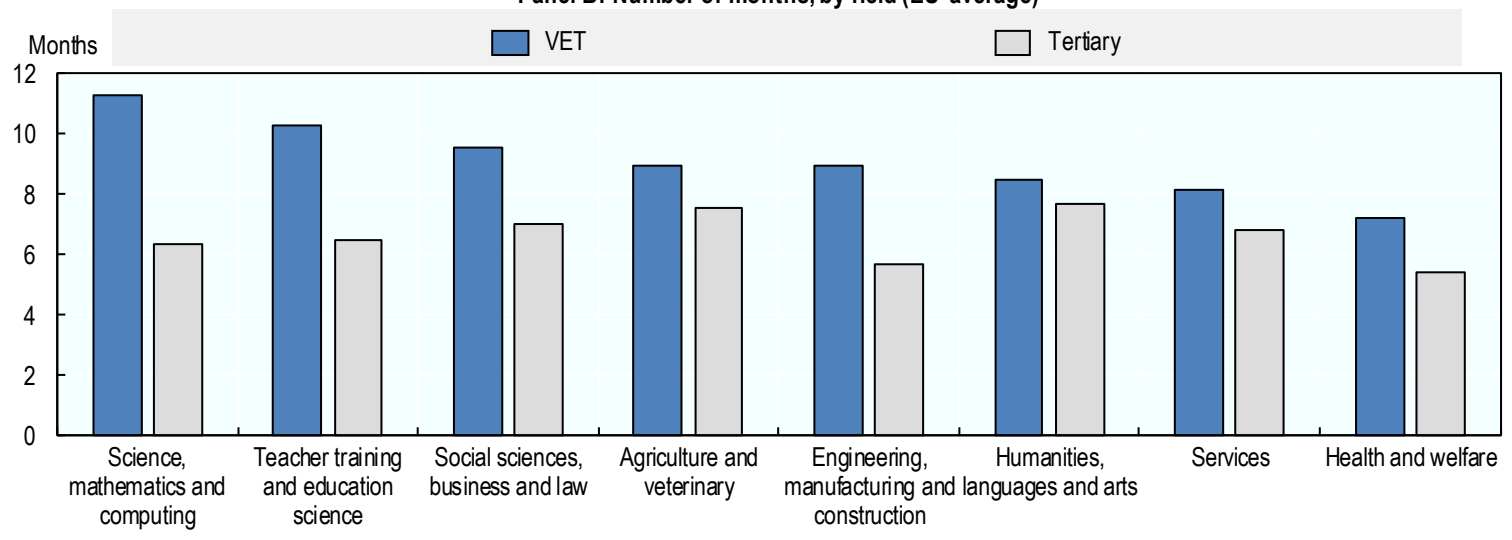

Note: Refers to individuals who obtained their degree between 2004 and the time of interview (2009) and are younger than 35 . Individuals who have not had a significant work experience are excluded, as well are individuals who had their first work experience more than 6 months before leaving education. Germany and Switzerland excluded because of different data collection regarding the starting date of the first significant job. Source: Authors' calculations using the EU-LFS 2009 ad hoc module.

While these data give an interesting indication of how quickly graduates transition into employment, they do not provide information about the graduates' status during the time between school and work. Graduates might spend time out of work because they have difficulty finding a job despite actively looking for one (i.e. they are unemployed), but they might also have left the labour market temporarily for a variety of reasons (i.e. they are inactive). Using EU-SILC data, Figure 6.2 takes a closer look at the labour market status of graduates in the month after obtaining their qualification. One month after graduating, $44.9 \%$ of VET graduates are employed. This is lower than among general education graduates $(48.8 \%)$ and tertiary education graduates $(55.8 \%)$, but substantially higher than among those who left education without and upper secondary education degree (35.7\%). The large majority of VET graduates who do not transition to employment within one 
month after graduation are unemployed. VET graduates are much less likely than general education graduates to transition into inactivity. The large share of general education graduates transitioning into inactivity after finishing upper-secondary or post-secondary non-tertiary education could be linked to graduates taking a gap year before continuing to higher education. For $14 \%$ of VET graduates transitioning into inactivity (and for $21 \%$ of those without an upper secondary education degree), the reason for being inactive is that they are fulfilling domestic tasks and care responsibilities. This is the case only for around $10 \%$ of general and tertiary education graduates transitioning from school to inactivity.

Figure 6.2. Labour market status one month after graduation (EU average, 2013-2016)

\section{Share of graduates}

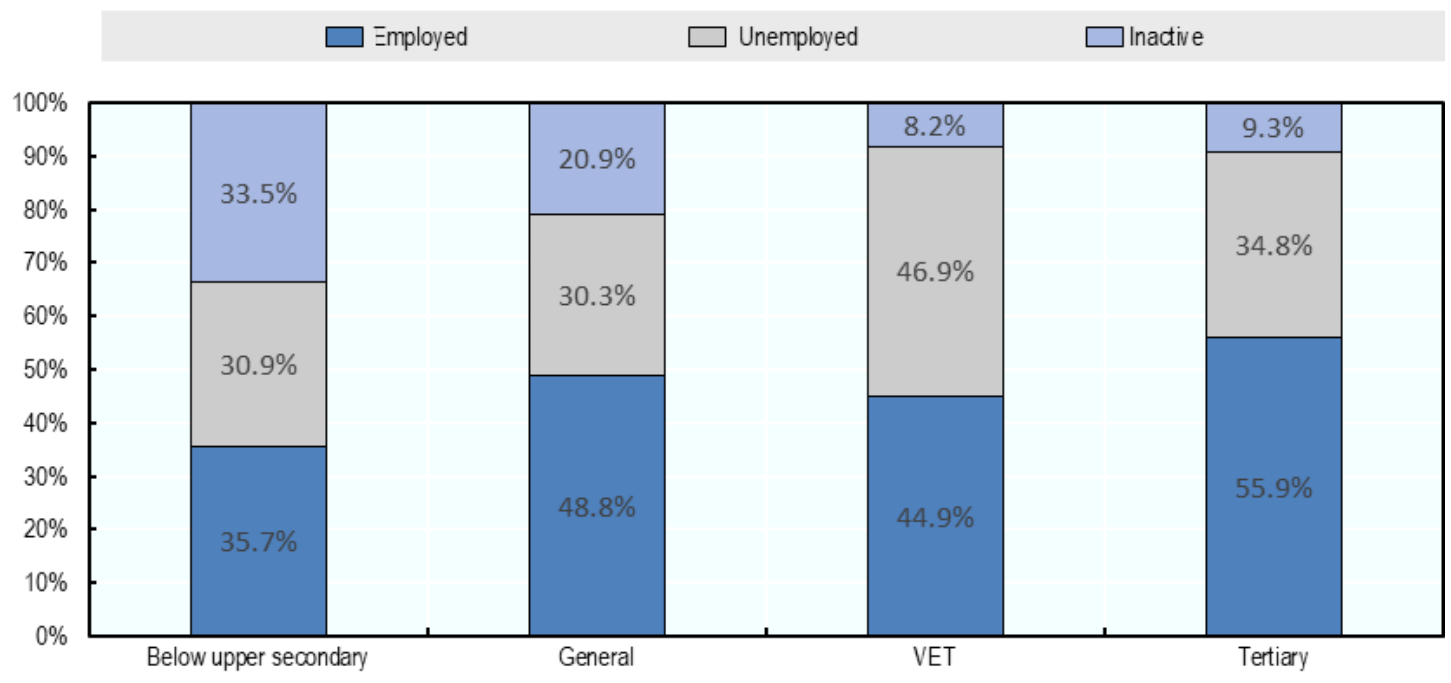

Note: Includes individuals aged 15 to 34 . Only includes graduates who report having obtained their highest degree the year prior to being interviewed. Graduates who return to education within the same year are excluded.

Source: Authors' calculations using EU-SILC data (2014-2017).

\subsubsection{VET graduates' first job is often a good match with their education}

One reason why certain graduates might find work quicker than others after graduating is their willingness to accept jobs that do not correspond to their education level. Figure 6.3 shows that VET graduates are on average less likely to be overqualified for their first job compared to general and tertiary education graduates. This could imply that some VET graduates might accept a longer period of unemployment (or inactivity) between graduating and starting a job because they are looking for a job that matches their education level. Moreover, for around 30\% of VET graduates their first job does not match their field of study, which is similar to the field-of-study mismatch observed among tertiary education graduates (in EU countries). 


\section{Figure 6.3. Mismatch in the first job of graduates}

Share of graduates employed in their first job
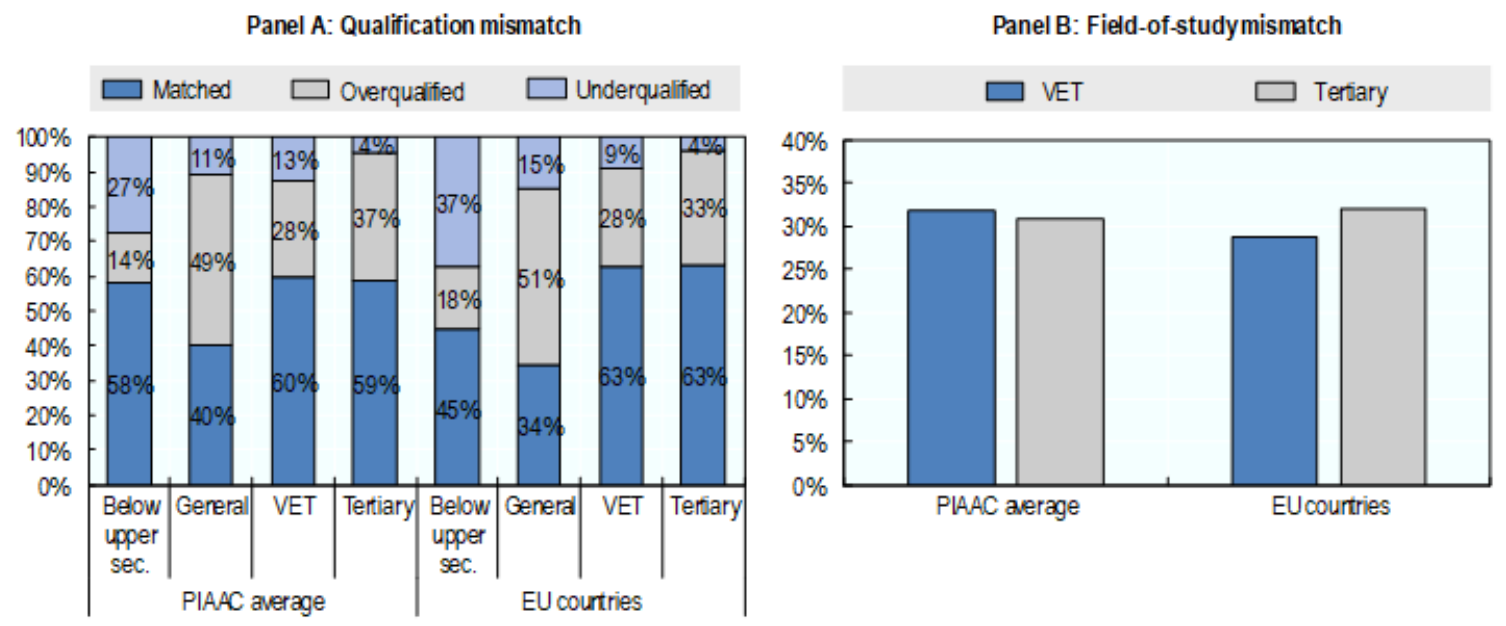

Note: Weighted average of all PIAAC countries and all EU countries participating in PIAAC, respectively. People in their first job are identified as those whose year of graduation equals the year they started working for their current employer, as well as those who graduated at most five years ago and report only having worked for one employer in the past 5 years. Qualification mismatch is calculated differently than in Figure 4.12 to better reflect the match for first time labour market entrants: Individuals are said to be matched if their education level is equal to the level they report as usual for getting the job when applying today and this usual level is deemed necessary. Only adults working in their first job and younger than 35 are included.

Source: Authors' calculations using PIAAC data (2012, 2014, 2017).

\subsection{Mobility between jobs}

\subsubsection{VET and general education graduates are equally likely to change jobs}

In most countries, there are no significant differences in the share of workers having changed jobs in the past year between the different education groups (see Figure 6.4). The main exceptions are the Netherlands, Denmark, Iceland and Sweden, where general education graduates have a considerably higher probability of having changed jobs than VET graduates (except in Sweden, where the share is roughly the same for general and tertiary education graduates). In Hungary, Poland, Austria, Estonia, Latvia and the Slovak Republic, graduates without an upper secondary education degree are less likely than VET graduates to have changed jobs. When comparing graduates with similar personal characteristics and accumulated work experience who currently work in the same industry and occupation, the differences are insignificant on average.

However, for those workers who have changed jobs, the reasons behind that change differ between education groups. VET graduates are slightly more likely than general education graduates to change jobs because they were obliged to stop by their employer $(10.1 \%$ versus $7.9 \%)$ or because of the end of a contract (18.7\% vs. $18 \%)$ and less likely to have left to take up or seek a better job (52.5\% vs. 55.4\%). Both general education graduates and VET graduates are less likely than tertiary education graduates to make the change to get a better job. For one in three graduates without an upper secondary degree who changed jobs the reason for doing so was an obligation by the employer or the end of a temporary contract, and less than half of them changed to get a better job. 
Figure 6.4. Graduates having changed jobs in the last year

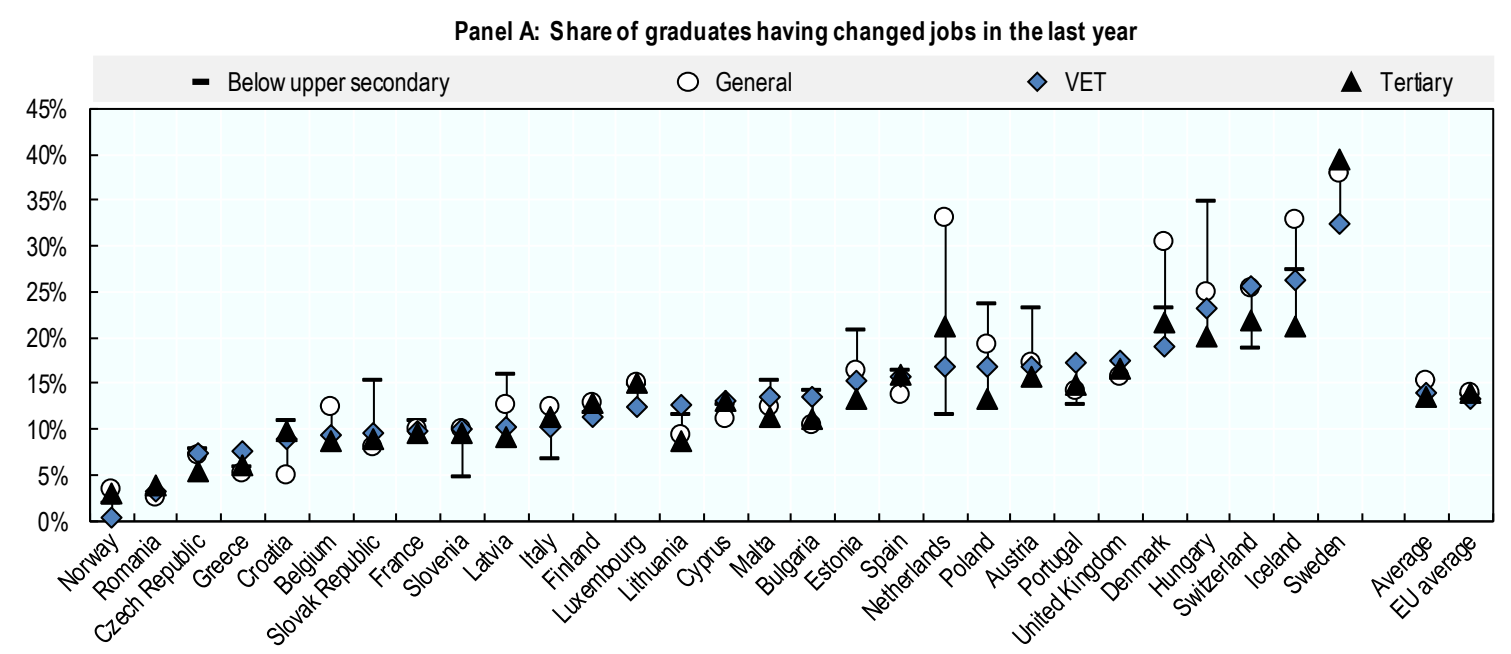

Panel B: Reasons for changing jobs

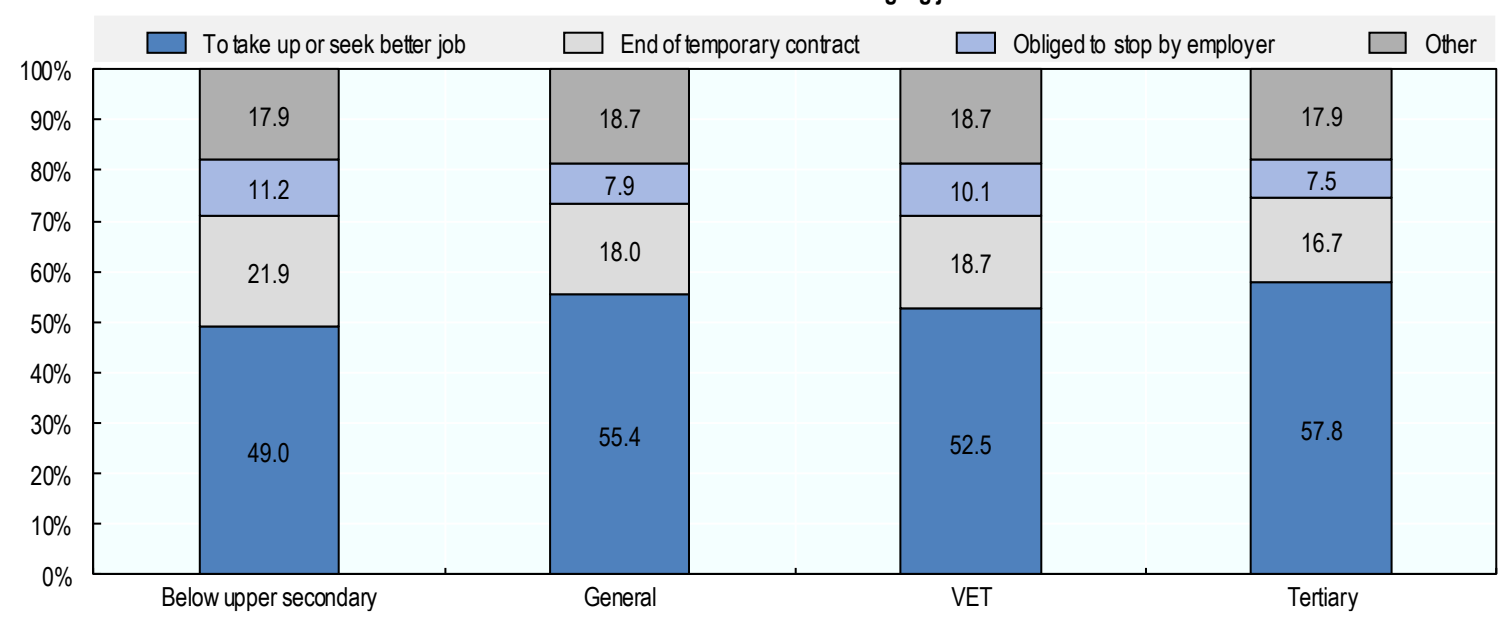

Note: Includes individuals aged 15 to 34 not in formal education. Panel B refers to the unweighted average of countries included in the EU-SILC. For employees, a change of job means a change of employer or a change of contract with the same employer. For the self-employed, a change of job means a change in the nature of the activity performed (or moving between employee and self-employed status). Completing one contract and beginning another does not constitute a change of job for the self-employed.

Source: Authors' calculations using EU-SILC data (2014-2017).

When looking at the intention of changing jobs, Figure 6.5 shows that VET graduates are least likely to be looking for another job while employed. Although the share of individuals who are looking for another job fluctuates with the economic cycle, VET graduates are continuously the least likely education group to be looking for another job. However, when comparing graduates who work within the same occupation group and with similar personal characteristics (i.e., age, gender, region, parents' educational level, having children), VET graduates' probability to look for another job is similar to that of general education graduates' (but significantly lower than tertiary education graduates).

The most common reason why VET graduates look for another job is that they wish to have better working conditions, such as better pay, shorter working or travel time, or higher quality of work. This is in line with the most stated reason for those who have been successful in finding another job (Figure 6.4, Panel B). Moreover, this reason has grown in 
importance in EU countries the past decade, from 43\% in 2005 to $48 \%$ in 2017. Surprisingly, considering the changing labour market and the increasing prevalence of temporary contracts among graduates, the risk of job-loss is a less common and decreasing reason for looking for another job for VET graduates $(15 \%$ in $2005 ; 11 \%$ in 2017). Moreover, VET graduates are significantly less likely than graduates from general education to state this reason for looking for another job, even when they work within the same occupation group.

Figure 6.5. Trends in looking for another job, by education
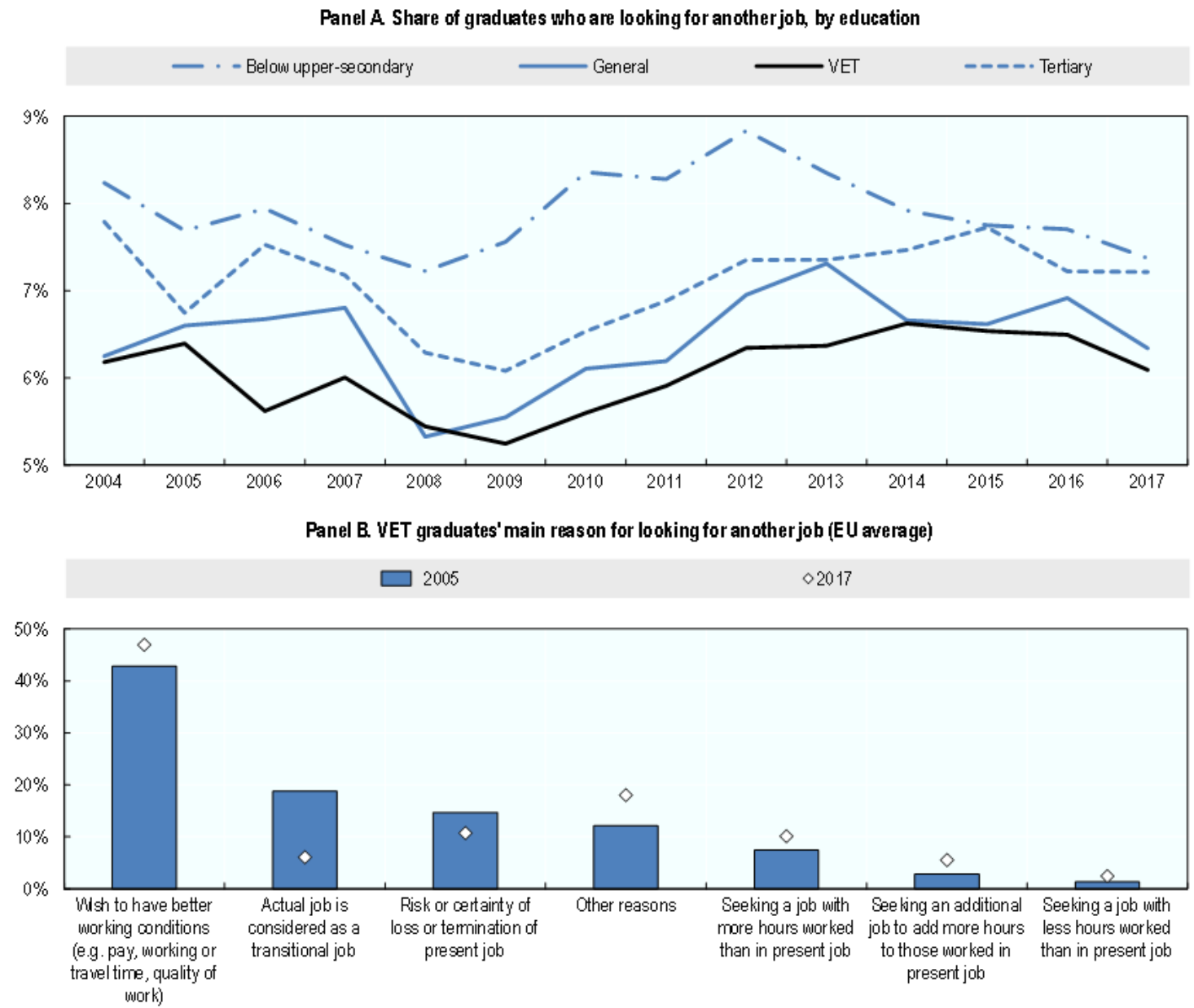

Note: Includes employed individuals aged 15 to 34 not in formal education. Based on a balanced sample of countries.

Source: Authors' calculations using EU-LFS data (2004-2017).

\subsubsection{VET graduates are less likely than general education graduates to move into better-quality occupations}

On average across countries included in the EU-SILC, 17.5\% of VET graduates change occupations from one year to the other (see Figure 6.6, Panel A). This is slightly lower than for general education graduates $(19.6 \%)$ and graduates without an upper secondary education degree $(19.3 \%)$, and roughly the same as for tertiary education graduates $(17.8 \%)$. In the large majority of countries, differences between the education groups are small. Notable exceptions are the Netherlands, Finland and Norway, where general 
education graduates have considerably higher probabilities of changing occupations. Only in Portugal are VET graduates substantially more likely to change occupations than other graduates. ${ }^{32,33,34}$

Figure 6.6. Share of graduates changing occupations
- Below upper secondary
General
$\diamond$ VET
A Tertiary
Panel A: Share changing occupations at least once in the past year

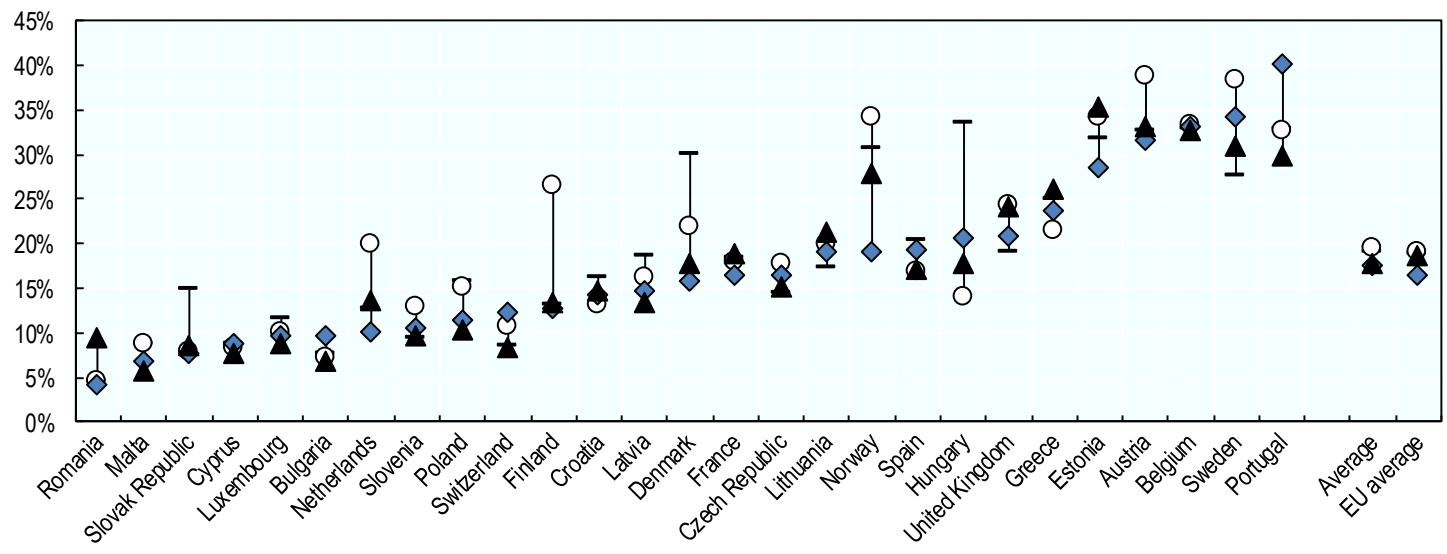

Panel B: Share changing occupations at least once in the past four years

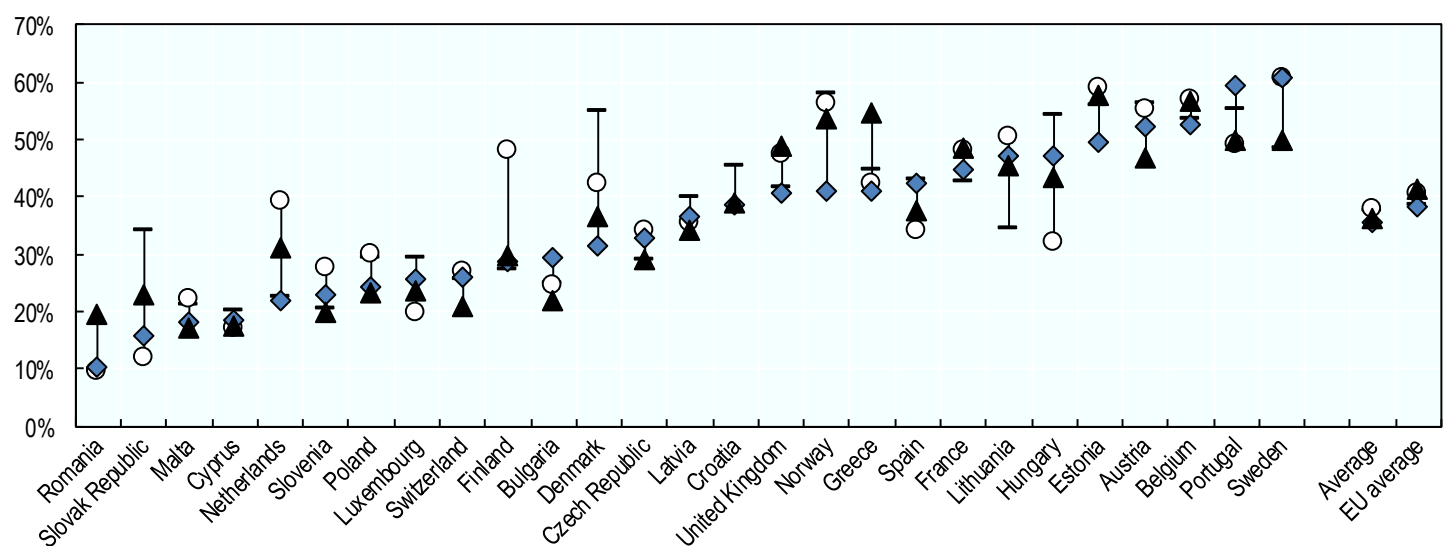

Note: Includes individuals aged 15 to 34 not in formal education. Changing occupations is defined as (i) being employed at time $t$ and $t-1$, but in different occupations, or (ii) being employed at time $t$ and not employed at $\mathrm{t}-1$, with the occupation in year $\mathrm{t}$ being different from the previous occupations reported when not employed at t-1. Panel B only includes individuals who are in the EU-SILC sample for at least four years.

32 Occupations are defined at the 2-digit ISCO level. This means that all occupation changes that happen within a two-digit occupation will not be recoded as changes (e.g. from cook (ISCO 512) to waiter or bartender (ISCO 513)).

${ }^{33}$ As occupation changes in Figure 6.6 are calculated on the EU-SILC panel data and job changes in Figure 6.4 on the cross-sectional data, they do not use the exact same sample. This could partially explain the counter-intuitive result that occupation changes happen more frequent than job changes.

34 These estimates are likely to suffer from some degree of measurement error as job titles can be misclassified into occupation groups. This could partially explain why occupational changes are recorded more frequently than self-reported job changes. 
Source: Authors' calculations using EU-SILC data (2014-2017).

When looking at a four-year period, $35.6 \%$ of VET graduates have changed occupations at least once (see Figure 6.6, Panel B). This is slightly lower than for general education graduates $(38 \%)$, graduates without an upper secondary education degree $(37.7 \%)$ and tertiary education graduates (36.6\%). In most countries the differences are relatively small.

However, there are substantial differences in the types of changes that are made by the different graduates. On average, $51.2 \%$ of occupation changes made by VET graduates are towards jobs with a lower risk of automation (see Figure 6.7, Panel A). This is roughly the same as for those without an upper secondary education degree (48.5\%), but slightly lower than for general education graduates $(55.6 \%)$ and tertiary education graduates $(54.3 \%)$. Moreover, when VET graduates move into lower risk occupations, the drop in the automation risk is lower than when tertiary and general education graduates move into lower risk occupations (but slightly higher than for those without an upper secondary education degree). At the same time, the increase in the risk for VET graduates when moving into higher risk jobs is also smaller than for general and tertiary education graduates, but larger than for graduates without and upper secondary education degree. This suggests that VET graduates move between occupations with relatively similar levels of automation probability, as do graduates without an upper secondary.

Figure 6.7. Change in the risk of automation when changing occupations
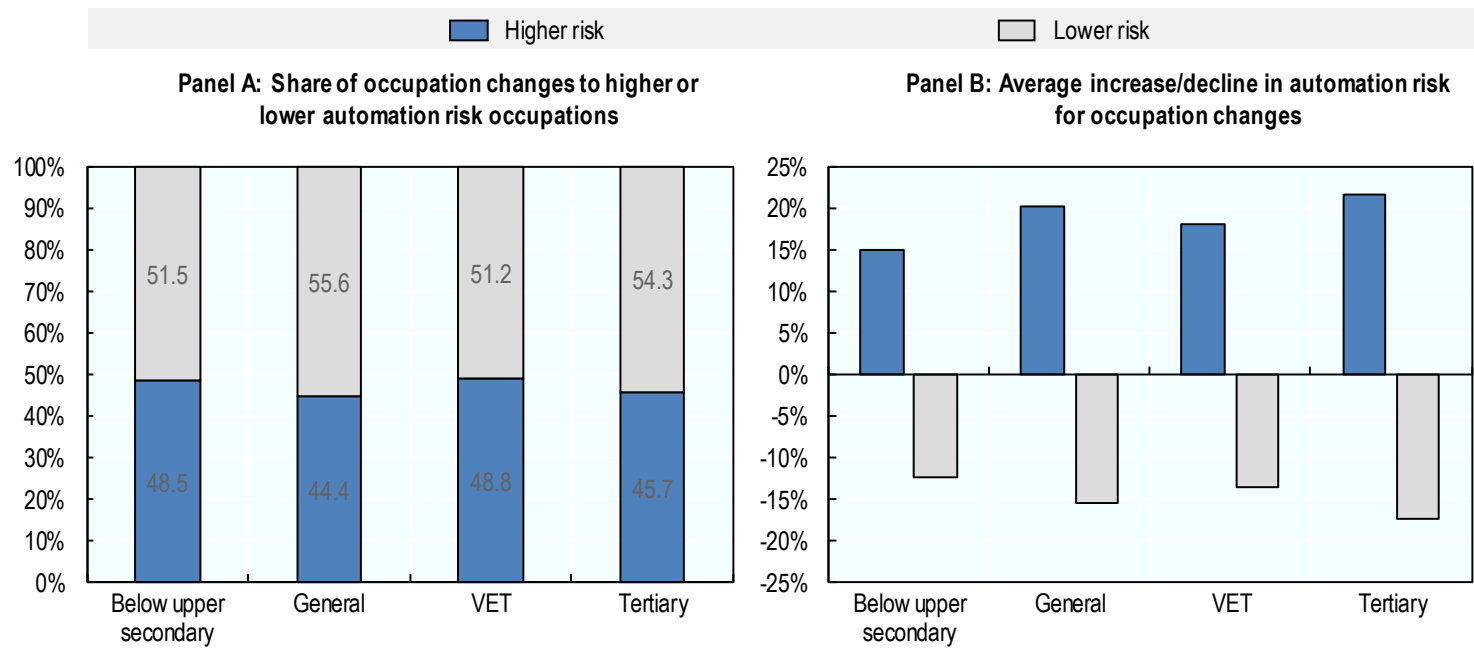

Note: Includes individuals aged 15 to 34 not in formal education. The risk of automation in calculated following the methodology used by Nedelkoska and Quintini $\left(2018_{[12]}\right)$, and averaged by ISCO occupation in each country. EU-SILC countries for which the risk of automation is not calculated by Nedelkoska and Quintini (2018[12]) (i.e. countries not in PIAAC), the cross-country average is used (EU-SILC countries only).

Source: Authors' calculations using EU-SILC data (2014-2017) and PIAAC data (2012, 2014, 2017).

Occupations also differ in terms of their skill level (measured as the average numeracy proficiency of workers in the occupation ${ }^{35}$ ), and graduates who switch occupations might differ in their probability of moving into high-skill occupations. As Figure 6.8 shows, just over half of the graduates from VET who change occupations move into higher-skill occupations. VET graduates and those without an upper secondary degree are less likely to

35 For EU countries not included in the PIAAC survey, the cross-country average numeracy proficiency per occupation is used. 
move into higher-skill occupations (51.3\% and 51.5\%, respectively) than graduates from general $(55.1 \%)$ and tertiary education (54.9\%). The average decrease or increase in skill level when changing occupations is very similar between education groups, although general education graduates who move into higher-skill occupations tend to make slightly larger jumps (i.e. a $7.5 \%$ increase in skill level compared to $6.8 \%$ for VET graduates).

Figure 6.8. Change in the average numeracy skill level when changing occupations

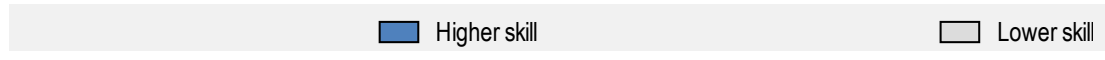

Panel A: Share of occupation changes to higher- or lower-skill occupations

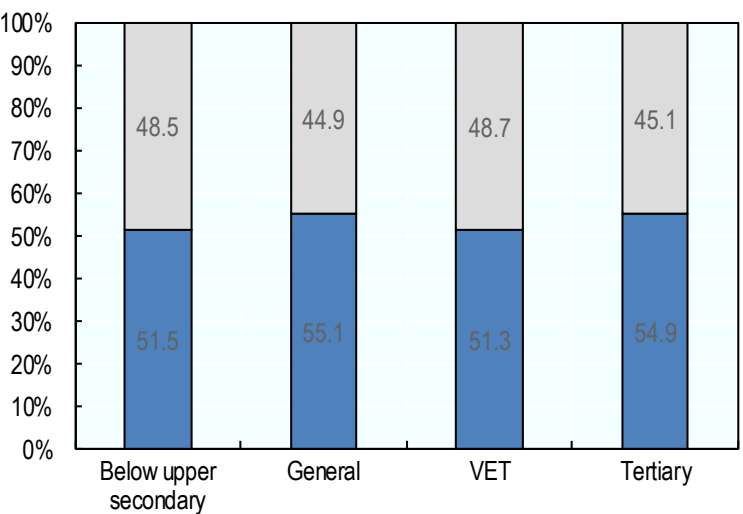

Panel A: Share of occupation changes to higher or lower median wage occupations

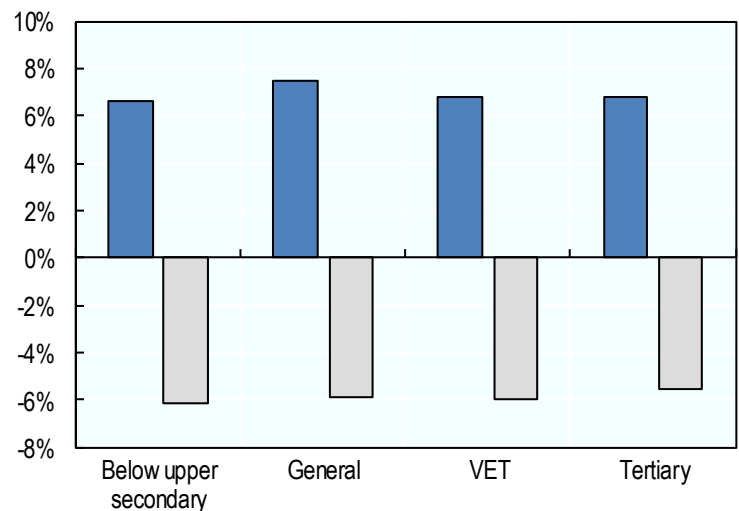

Note: Includes individuals aged 15 to 34 not in formal education. For EU-SILC countries for which numeracy proficiency levels are not available (i.e. countries not in PIAAC), the cross-country average is used (EU-SILC countries only).

Source: Authors' calculations using EU-SILC data (2014-2017) and PIAAC data $(2012,2014,2017)$

In line with the finding that VET graduates are less likely to move into higher-skill jobs, Figure 6.8 shows that over $50 \%$ of VET graduates who change occupations move into higher-wage occupations. Graduates from VET and those without and upper secondary education degree are slightly less likely to move into higher-wage occupations $(53 \%)$, than graduates from general education (56.7\%) and tertiary education (55.3\%). ${ }^{36}$ Moreover, when VET graduates move into higher-wage occupations, the increase in average wage level is smaller than for general and tertiary education graduates $(26.6 \%$ versus $31.9 \%$ and $33.4 \%$, respectively), but higher than for those without an upper secondary education degree. However, when moving into a lower-wage occupation, the wage drop is smaller for VET graduates than for general and tertiary education graduates, and larger than for those without an upper secondary education degree. This shows that VET graduates (and graduates without an upper secondary education degree) move between occupations at similar wage levels.

Overall, these findings suggest that VET graduates have substantial opportunities for upward mobility, but also that their probability of making positive occupational changes is lower compared to general and tertiary education graduates. When estimating this probability for the different education groups and controlling for the starting occupation

${ }^{36}$ As the wage information the EU-SILC refers to annual earnings and no information on the timing (within the year) of the occupational change is available, it is not possible to compare at the individual's level the wage before and after changing occupations. Information presented here therefore relates to median wages in the occupation per country, rather than individual wages. 
(and other factors, such as age, gender and previous and current employment status), these findings are confirmed. Indeed, Table 6.1 shows that general education graduates are significantly more likely than VET graduates employed in similar occupations to move into occupations that have a higher average skill level, higher median wage level and lower risk of automation. Also compared to tertiary education graduates employed in similar occupations, VET graduates have a lower probability of making these positive moves, and the differences are much larger than between VET and general education graduates. Graduates who do not have an upper secondary education degree are even less likely than VET graduates to make these positive moves.

Figure 6.9. Change in the median occupation wage when changing occupations
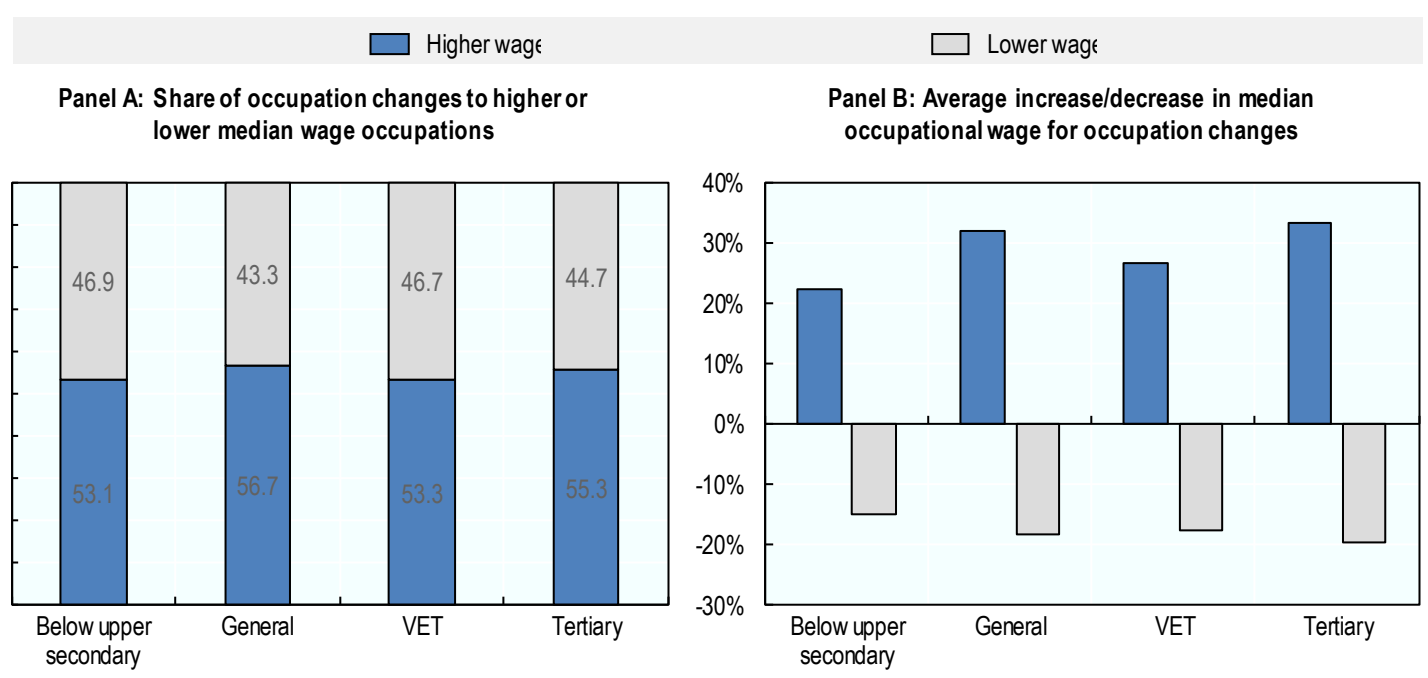

Note: Includes individuals aged 15 to 34 not in formal education. Wages are calculated at the occupation level, not at the individual level. Wages refer to median hourly wages, with hourly wages derived from annual earnings and information on months worked during the income reference year and usual hours worked. Source: Authors' calculations using EU-SILC data (2014-2017). 
Table 6.1. Probability of making a positive occupation change

Probit (marginal effects) and OLS regression estimates

\begin{tabular}{|c|c|c|c|c|c|c|}
\hline & \multicolumn{2}{|c|}{ Skill level } & \multicolumn{2}{|c|}{ Median wage level } & \multicolumn{2}{|c|}{ Risk of automation } \\
\hline & $\begin{array}{l}\text { Probability of } \\
\text { moving to } \\
\text { occupation } \\
\text { with higher } \\
\text { average skill }\end{array}$ & $\begin{array}{l}\text { \% difference in } \\
\text { average skill } \\
\text { level }\end{array}$ & $\begin{array}{l}\text { Probability of } \\
\text { moving to } \\
\text { occupation } \\
\text { with higher } \\
\text { median wage }\end{array}$ & $\begin{array}{l}\% \text { difference in } \\
\text { median wage } \\
\text { level }\end{array}$ & $\begin{array}{l}\text { Probability } \\
\text { of moving to } \\
\text { occupation } \\
\text { with lower } \\
\text { risk of } \\
\text { automation }\end{array}$ & $\begin{array}{c}\% \text { difference in } \\
\text { average risk of } \\
\text { automation }\end{array}$ \\
\hline $\begin{array}{l}\text { Below upper secondary } \\
\text { (vs. VET) }\end{array}$ & $\begin{array}{r}-0.043^{* *} \\
(0.017)\end{array}$ & $\begin{array}{r}-1.490^{\star * *} \\
(0.322)\end{array}$ & $\begin{array}{r}-0.064^{\star \star \star} \\
(0.016)\end{array}$ & $\begin{array}{r}-4.293^{* * *} \\
(0.847)\end{array}$ & $\begin{array}{r}-0.046^{* * *} \\
(0.017)\end{array}$ & $\begin{array}{l}1.496^{* *} \\
(0.694)\end{array}$ \\
\hline General (vs. VET) & $\begin{array}{r}0.061^{* * *} \\
(0.018)\end{array}$ & $\begin{array}{r}1.424^{* * *} \\
(0.351)\end{array}$ & $\begin{array}{c}0.028^{*} \\
(0.017)\end{array}$ & $\begin{array}{r}4.070^{\star * *} \\
(1.131)\end{array}$ & $\begin{array}{r}0.048^{\star \star *} \\
(0.018)\end{array}$ & $\begin{array}{r}-3.277^{\star * *} \\
(0.859)\end{array}$ \\
\hline Tertiary (vs. VET) & $\begin{array}{r}0.254^{* * *} \\
(0.015)\end{array}$ & $\begin{array}{r}5.276^{\star \star \star *} \\
(0.300)\end{array}$ & $\begin{array}{r}0.189^{\star \star *} \\
(0.015)\end{array}$ & $\begin{array}{r}17.048^{* * *} \\
(0.915)\end{array}$ & $\begin{array}{r}0.205^{\star \star \star} \\
(0.015)\end{array}$ & $\begin{array}{r}-12.875^{\star * *} \\
(0.691)\end{array}$ \\
\hline Number of observations & 23954 & 23954 & 23536 & 23536 & 23848 & 23848 \\
\hline
\end{tabular}

Note: Includes individuals aged 15 to 34 not in formal education. Includes controls for age (15-24, 25-29, 30-34), gender, previous and current employment status (full-time employees, part-time employee, full-time self-employed, part-time self-employed, unemployed, inactive), previous occupation (at year t-1) and country. Standard errors in parenthesis. For the probit regressions, the independent variables equal 0 when the move is negative and 1 when the move is positive.

Source: Authors' calculations using EU-SILC data (2014-2017).

When looking in detail at the starting and destination occupations of graduates who change occupations from one year to the next, some clear patterns emerge (see Figure A C.2, Figure A C.3, Figure A C. 4 and Figure A C.5 for an overview). Firstly, general education graduates working in sales occupations move into many different types of occupations, including ones that are higher-skill (e.g. business and administration associate professionals, service managers and clerical jobs) and ones that are at a similar skill level (e.g. personal care and personal services jobs). However, there are also many general education graduates who make these moves in the opposite direction. Also, general education graduates employed in some elementary occupations, like labourers, move into higher-skill jobs (e.g. drivers, plant and machine operators). Secondly, VET graduates working in sales occupations move into many different types of occupations, as do general education graduates, but they are much less likely to end up in associate professionals or management jobs. In general, VET graduates are less likely than general education graduates to make moves to occupations that are ranked much higher in terms of average skill levels. One clear example is personal care workers, for which a significant share of general education graduates changing occupations manage to move into health or teaching professionals occupations, while this is not the case for VET graduates employed as personal care workers. Thirdly, tertiary education graduates generally move between managers, professionals and associate professionals occupations (with the same specialisation), and between clerical occupations and business and administrative associate professionals occupations. Tertiary education graduates working as sales workers also move towards clerical or business and administrative associate professionals occupations. Finally, graduates without an upper secondary education degree move mainly from jobs as labourer towards mid-level jobs in craft occupations, assembly jobs and machine operator jobs. Another frequent move for these graduates is between sales and personal service jobs (in both directions). 


\subsection{Mobility between employment statuses}

\subsubsection{Unemployment spells between jobs are as common among VET graduates as among general education graduates}

Rather than moving directly from one job to another, graduates might be moving in and out of employment. VET and general education graduates have similar probabilities of having experienced at least one unemployment spell in the last four years: $69.2 \%$ of VET graduates and $70.8 \%$ of general education graduates did not experience any unemployment spells. Around two thirds of graduates who had some unemployment in the last four years only faced one unemployment spell. This share is similar for VET and general education graduates $(65.1 \%$ and $65.9 \%$ respectively). Tertiary education graduates experience fewer unemployment spells ( $80 \%$ have no unemployment spells), and therefore generally have less volatility in their employment status. By contrast, graduates without an upper secondary education degree have substantially higher probabilities of facing one or more unemployment spells, with only $60 \%$ not having faced unemployment.

\section{Figure 6.10. Number of unemployment spells in a four-year period}

Percentage of graduates by number of employment spells

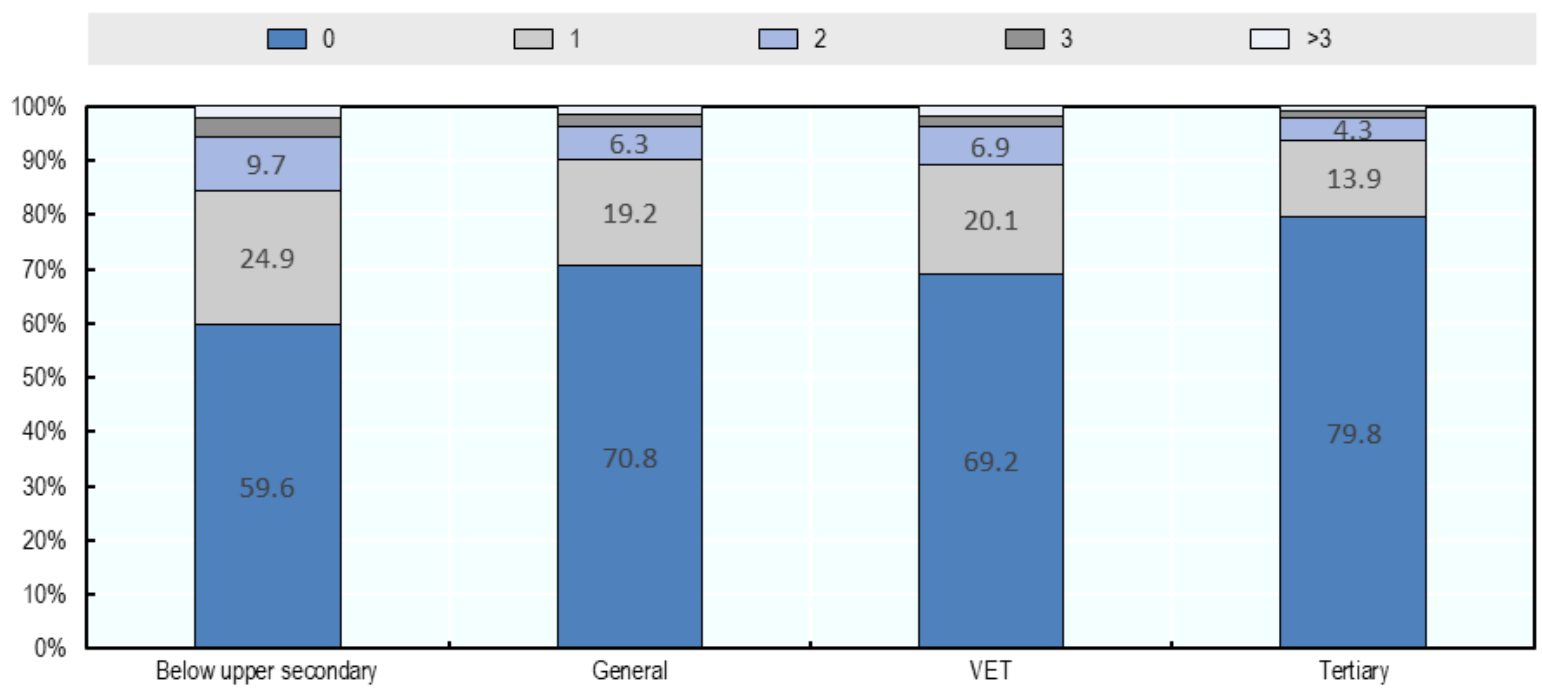

Note: All individuals age 15 to 34 who are observed for four years are included. Years in which individuals spend six months or more in formal education are excluded. Unemployment spells that are shorter than half a month are not observed.

Source: Authors' calculations using EU-SILC data (2014-2017).

Not only the frequency of unemployment spells matters, but also their duration. When graduates struggle to find a new job, they might be unemployed for a substantial period of time. Research suggests that long periods of unemployment lead to an increased future incidence of unemployment and lower earnings in future jobs, contributing to higher lifetime inequality (Arulampalam, Gregg and Gregory, 2001 ${ }_{[62]}$ ). An important aspect of this type of unemployment scarring is found to be the depreciation of skills during periods of non-employment (Edin and Gustavsson, 2008 ${ }_{[63]}$ ). On average in European countries, the average number of months unemployed VET graduates have spent not working is 
similar to that of general education graduates. ${ }^{37,38}$ In Latvia, Spain and Estonia, the average non-employment spell of unemployed general education graduates lasts more than 3 to 4 months longer than the average non-employment spell among unemployed VET graduates. However, in Germany, Malta and Romania the opposite holds. In most countries, unemployed tertiary education graduates have the shortest non-employment duration, and those without an upper secondary education degree face the longest nonemployment spells. These findings are broadly consistent with the long-term unemployment rates discussed in Chapter 4.

Figure 6.11. Duration of non-employment spells of unemployed graduates, by education

Average number of months

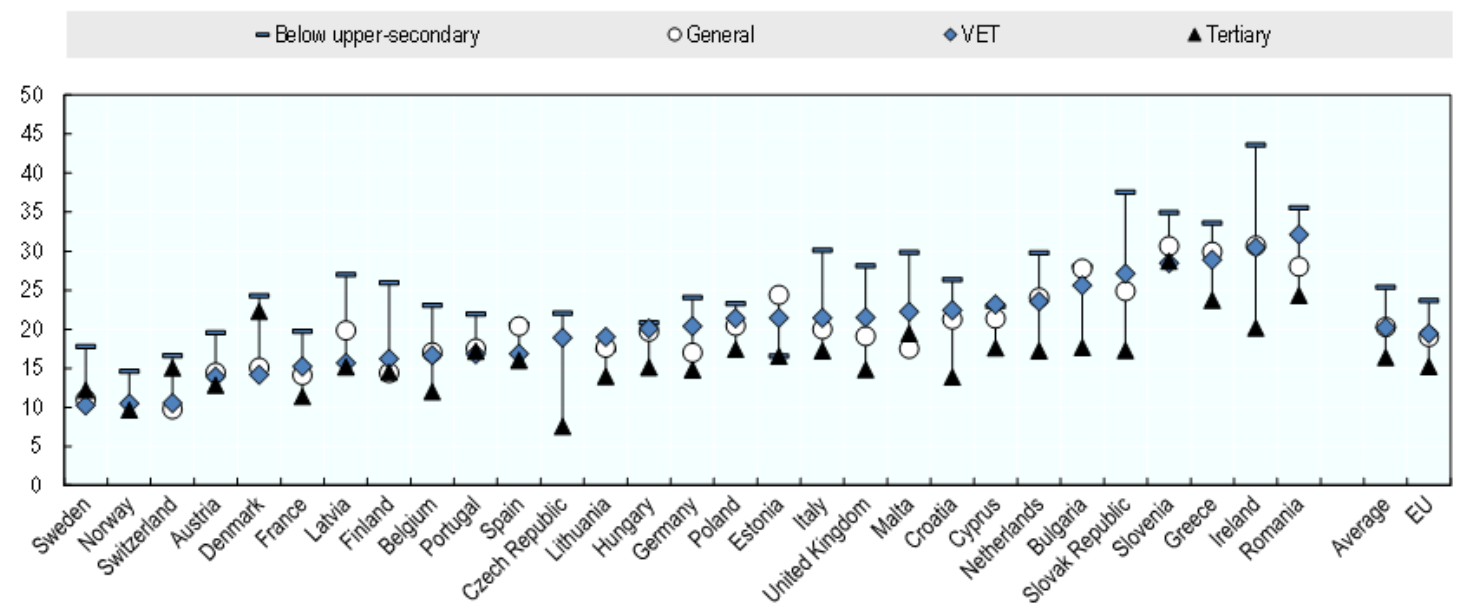

Note: Includes individuals aged 15 to 34 who are currently unemployed. 'Non-employment spells' are the number of months since the unemployed person last worked. This may include time spent in unemployment, inactivity or education or training.

Source: Authors' calculations using EU-LFS data (2014-2017).

\subsection{Conclusion}

One of the main benefits of VET is that it prepares students directly for the labour market, as such contributing to a smooth transition from school to work. This chapter shows that VET graduates indeed have shorter spells between graduating and entering their first significant job than general education graduates and graduates without an upper secondary education degree. Compared to general education graduates, VET graduates are substantially less likely to become inactive after leaving education. Moreover, the first job of VET graduates is often a good match with their education level, more so than is the case for general education graduates.

${ }^{37}$ Replacing spells (calculated in years) that are longer than the years since graduation from the highest obtained degree, by years since graduation*12 (i.e., only taking into account non-employment spells since graduation) does not alter the main findings.

${ }^{38}$ Findings are broadly the same when using EU-SILC data and focussing on unemployment spells only (in contrast to non-employment), see Annex C. However, because of sample size issues, this analysis using EU-SILC can only be carried out for a subset of European countries. 
Once in employment, VET graduates have the same probability of changing jobs as other graduates, and have substantial opportunities for upward mobility in terms of their occupations' skill and wage level. However, compared to general education graduates, they are less likely to move into jobs at a higher skill or wage level or with a lower risk of automation. At the same time, VET graduates are slightly less likely to say that they changed jobs to take up or seek a better job, and less likely to be looking for another job when employed. VET and general education graduates are equally likely to face unemployment spells and on average these spells have similar durations. Unemployment spells are substantially more common among graduates without an upper secondary degree.

These findings suggest that VET graduates indeed have an advantage in terms of labour market entry compared to general education graduates, and that they do equally well in the labour market with respect to the probability of unemployment. However, the results also suggest that the transitions between jobs that VET graduates make are less positive than those made by general education graduates, and that they are less proactively looking for better job opportunities. This could be worrying, especially in times of rapid changes in the type and content of jobs available. 


\section{Chapter 7. Labour market outlook for vocational education graduates}

Structural changes have had a profound impact on the structure of the labour market and therefore also on the skills employers are looking for. These megatrends can be expected to have a continuing impact on labour markets in the coming years or decades, altering even further the demand for and supply of skills. This chapter looks at skills imbalances observed in today's labour market, but also takes a forward-looking perspective and analyses the implications of expected changes on VET graduates compared to other graduates.

\subsection{Short-term outlook}

\subsubsection{Many occupations that are important for VET graduates are facing surpluses}

The ease of finding a job that matches the individual's skills depends on the demand for and supply of those skill. When the demand for a certain skill is higher than its supply (i.e. a situation of skills shortages), firms have difficulties finding the right workers for their vacancies. Individuals with those skills will find it easy to get a job matching their skills. In the opposite case, when the demand for a skill is lower than the supply (i.e. skills surplus), there is an abundance of workers with these skills, which makes it more difficult for individuals with these skills to find jobs that match their skill profile. The type of skills in shortage or surplus, and the intensity of these imbalances, will therefore be an important factor to understand the short-term employment outlook for adults with different skill profiles.

Using information from the OECD Skills for Jobs database (see Box 7.1 for more details), Figure 7.1 compares the shortage or surplus intensity of an occupation to i) the relative importance of that occupation for VET graduates' employment (i.e. the number of VET graduates employed in that occupation relative to the total number of VET graduates in the labour market, Panel A), and ii) the fraction of workers (aged 15-34) in that occupation who have a VET degree (i.e. the number of VET graduates in each occupation relative to the total number of graduates in the occupation, Panel B). The negative relationship in Panel A implies that the occupations that employ the largest proportion of all VET graduates experience smaller shortages or even surpluses. ${ }^{39}$ However, with a correlation coefficient of -0.29 (significant at the $10 \%$ level), the relationship is not very strong at the EU level. Panel B shows that the occupations that predominantly employ VET graduates (i.e. a large fraction of the workers employed in those occupations have a VET degree) are more likely to experience (relatively large) surpluses. This correlation is stronger than the one in panel A, with a correlation coefficient equal to -0.52 (significant at the $1 \%$ level).

${ }^{39}$ Even when removing occupation 52 (sales workers), which could be considered an outlier, the negative correlation remains. However, the correlation drops slightly (to -0.27) and is no longer statistically significant at the $10 \%$ level. 
The relationships found at the EU-average level are also confirmed when using all the country-occupation observations. ${ }^{40}$ Indeed, the correlation coefficients are negative and significant for both VET variables, but smaller than in the EU-average case. Overall, what these correlations show is that occupations that employ a large number of VET graduates (relative to the total number of VET graduates in the labour market), and especially the ones that employ mainly VET graduates (relative to other workers in that occupation), are more likely to be facing excess supply (relative to demand) on average in European labour markets. This means that the outlook for VET graduates is not very bright in some of their default occupations. The best short-term outlook can be observed for occupations in the group of professionals (ISCO 2) and technicians and associate professionals (ISCO 3). These occupations face substantial shortage on average in the EU but do not employ many VET graduates.

Figure 7.1. Skills imbalances and VET employment by occupation
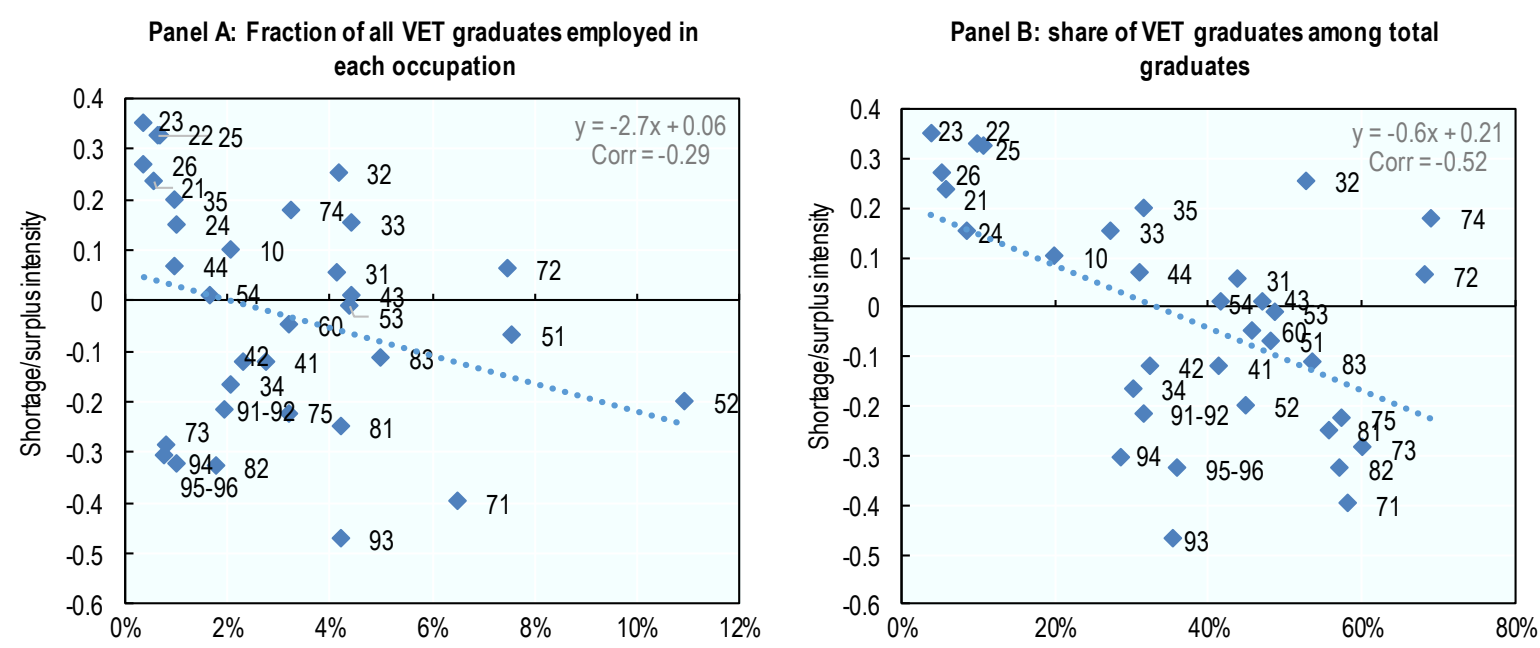

Note: Weighted average of EU countries (excluding Luxembourg, Iceland, Malta and Croatia). Numbers refer to ISCO-08 occupation codes. The occupational shortage index (on the y-axis) ranges between -2.5 and 2.5, with negative values referring to surpluses and positive values to shortages. See Box 7.1 for details on the methodology to calculate shortages and surpluses. VET shares refer to 2017 and only include employed individuals aged 15 to 34 not in formal education. Imbalances refer to the latest available year.

Source: Authors' calculations using EU-LFS data and the OECD Skills for Jobs database.

\subsubsection{Some typical VET occupations are in shortage}

It is important to note that not all default VET occupations have a negative short-term outlook: metal and machinery workers (ISCO 72, a large occupation) and electrical and electronic trades workers (ISCO 74, a small occupation) are both typical VET jobs and they are facing shortages in the EU on average. Figure 7.2 confirms this at the country level, by looking at imbalances in each country in i) the three occupations that employ the largest

${ }^{40}$ For the calculation of the correlation between imbalance intensity and the share of VET among total graduates the latter variable is demeaned at the country level to take into account that countries differ in the overall share of VET graduates (in the entire labour market). 
fraction of all VET graduates ${ }^{41}$, and ii) the three occupation with the highest share of VET graduates among total graduates working in the occupation ${ }^{42}$. Only in a few countries are all three occupations that employ most VET graduates in surplus (i.e. in Lithuania, Cyprus, Sweden, France, Switzerland and Finland), and in even fewer countries are all three occupations with the largest share of VET graduates among their workers in surplus (i.e. in Slovenia, Greece, Cyprus, France and Finland). In more than half of the countries, none or only one of the occupations with the largest share of VET graduates among their workers are found to be in surplus. Moreover, some occupations that typically require higher VET degrees, such as certain health care occupations, are facing considerable shortages in many EU countries.

\section{Figure 7.2. Surpluses in VET occupations, by country}

Number of top 3 occupations that are facing surpluses

口 Occupations employing the largest fraction of all VET graduates $\quad$ 口 Occupations with the largest share of VET graduates among total graduates

Number of occupations

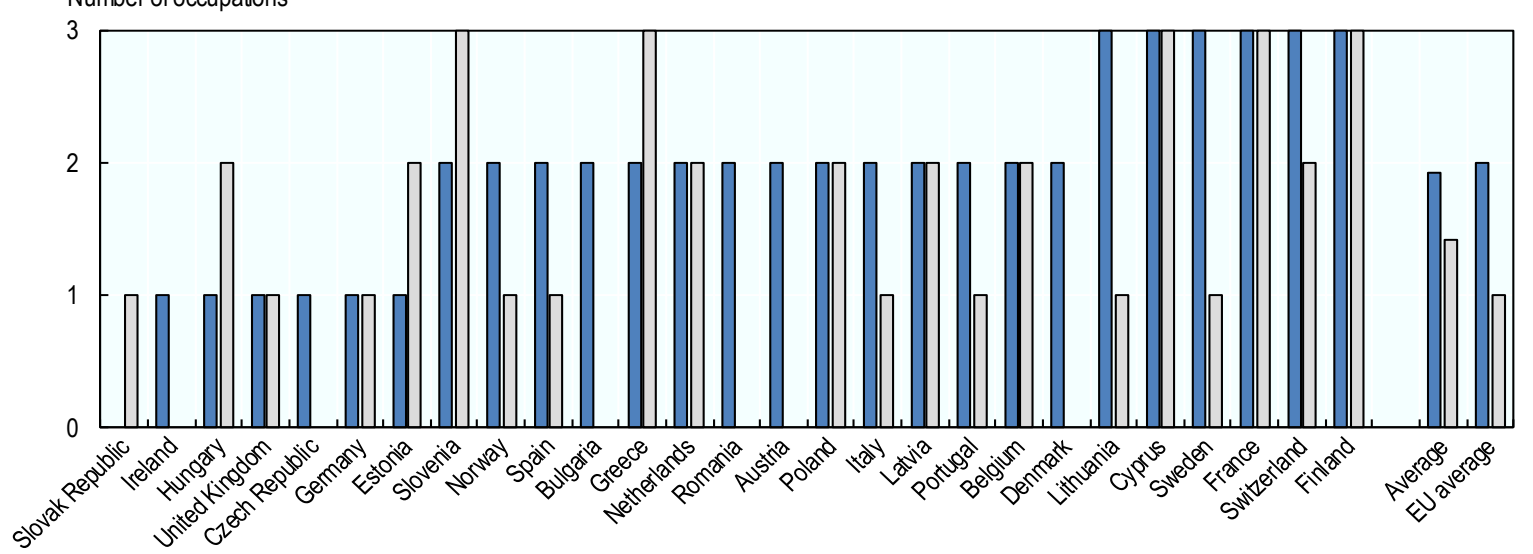

Note: Values represent the number of occupations in surplus among the three occupations with the highest fraction of VET graduates employed or the three occupations with the highest share of VET graduates among total graduates (aged 16 to 34, not in formal education), respectively. See Box 7.1 for details on the methodology to calculate shortages and surpluses.

Source: Authors' calculations using EU-LFS data and the OECD Skills for Jobs database.

${ }^{41}$ In the large majority of countries, sales workers (ISCO 52) are among the top 3 occupations employing the largest fraction of VET graduates. In around half of the countries, personal service workers (ISCO 51), building and related trades workers (ISCO 71), and metal and machinery workers (ISCO 72) feature in the top three.

${ }^{42}$ In the large majority of countries, electrical and electronic trades workers (ISCO 74) and metal and machinery workers (ISCO 72) are in the top 3 occupations with the highest share of VET graduates among their workers. In around one out of three countries, building and related trades workers (ISCO 71) features in the top three. 


\section{Box 7.1. The OECD Skills for Jobs Indicators}

The OECD Skills for Jobs indicators measure which skills are hard-to-find (in shortage) or easy-to-find (in surplus) in the labour market. Skill shortages emerge when employers are unable to recruit staff with the necessary set skills in the accessible labour market and at the going rate of pay and working conditions. Skill surpluses arise in the opposite case, when the supply exceeds the demand for a given skill.

The indicators measuring these imbalances (both shortages and surpluses) in the labour market are constructed following a two-step approach that delivers two different, though related, sets of information on: i) Occupational imbalances -measuring the extent by which jobs in each occupational group are hard or easy to fill for firms in the current labour market; and ii) Skills shortages and surpluses - measuring the extent by which each skill dimension is (or not) hard to find in the labour market.

\section{i) Occupational imbalances}

The Occupational shortage indicator is a composite indicator that ranks occupations in shortage or in surplus within each country based on the analysis of five sub-components: wage growth, employment growth, hours worked growth, unemployment rate, and change in the share of underqualified workers.

For each country, occupational group and sub-component, long-run trends are compared to the economy-wide trend. This comparison sheds light on whether the specific occupational group is outperforming/underperforming the rest of the economy, and by how much.

\section{ii) Skills shortages and surpluses}

The Occupational shortage indicator is used to build indicators of skills shortages and surpluses. Information on skill requirements in each occupation are extracted from the O*NET database which provides categorical data about the skills required to perform the tasks of more than 800 different occupations. The values of the Occupational shortage indicators are used to weight the importance and level of the skill requirements associated to each occupational group.

Source: Adapted from OECD (2018[64]; $\left.2017_{[47]}\right)$.

\subsection{Medium-term outlook}

\subsubsection{The number of crafts and related trades jobs is projected to decline}

As discussed above, the occupational structure of labour markets in EU countries have undergone structural changes in the last few decades, with employment growth concentrated in the occupation groups of 'professionals' and 'service and sales workers', and a declining employment share for 'craft and related trades workers'.

According to projections from Cedefop and Eurofound (2018 $\left.8_{[9]}\right)$, this trend is likely to continue in the next decades. Their forecasts show that across EU countries, total employment will grow the most for professionals, as well as technicians and associate professionals. Managers, service and sales workers, and elementary occupations will also experience growth, but at a slower pace. Employment levels will go down for craft and related trades workers, clerks and skilled agricultural and forestry workers (see Figure 7.3). 
As these projections were carried out before the COVID-19 dynamics, they do not reflect the expected impact of this health crisis on the labour market.

Figure 7.3. Broad trends in occupational employment (EU, 2011-2030)

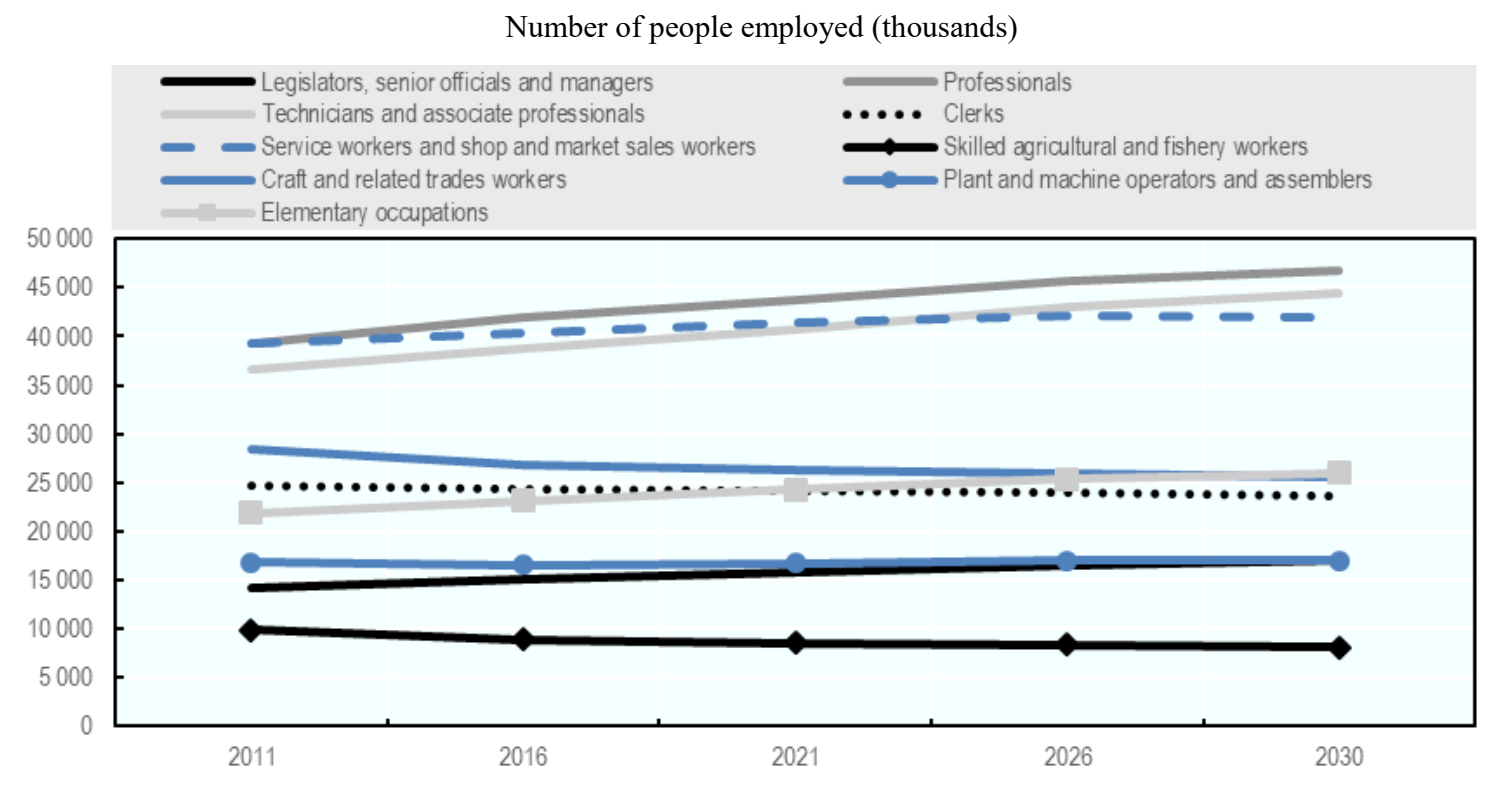

Source: Cedefop and Eurofound (2018[9]).

The demand for graduates does not only come from the creation of new jobs, but also from replacement demand. A significant part of the demand for skills in Europe is replacement demand, see Figure 7.4 (Cedefop and Eurofound, 2018 ${ }_{[9]}$ ). In general terms, replacement demand can be seen as job openings arising from a worker leaving a job, temporarily or permanently. The main cause of permanent separations is due to retirement, but other reasons for withdrawal from the labour force are emigration, sickness and, especially for women, family formation. Even though certain occupations might be shrinking, they do not disappear altogether, which means that openings will still be created to replace workers who leave those occupations. Replacement demand reflects to a large extent the size of the occupation, and as occupations shrink their replacement demand also declines. 
Figure 7.4. Job openings by broad occupation group, 2016-2030

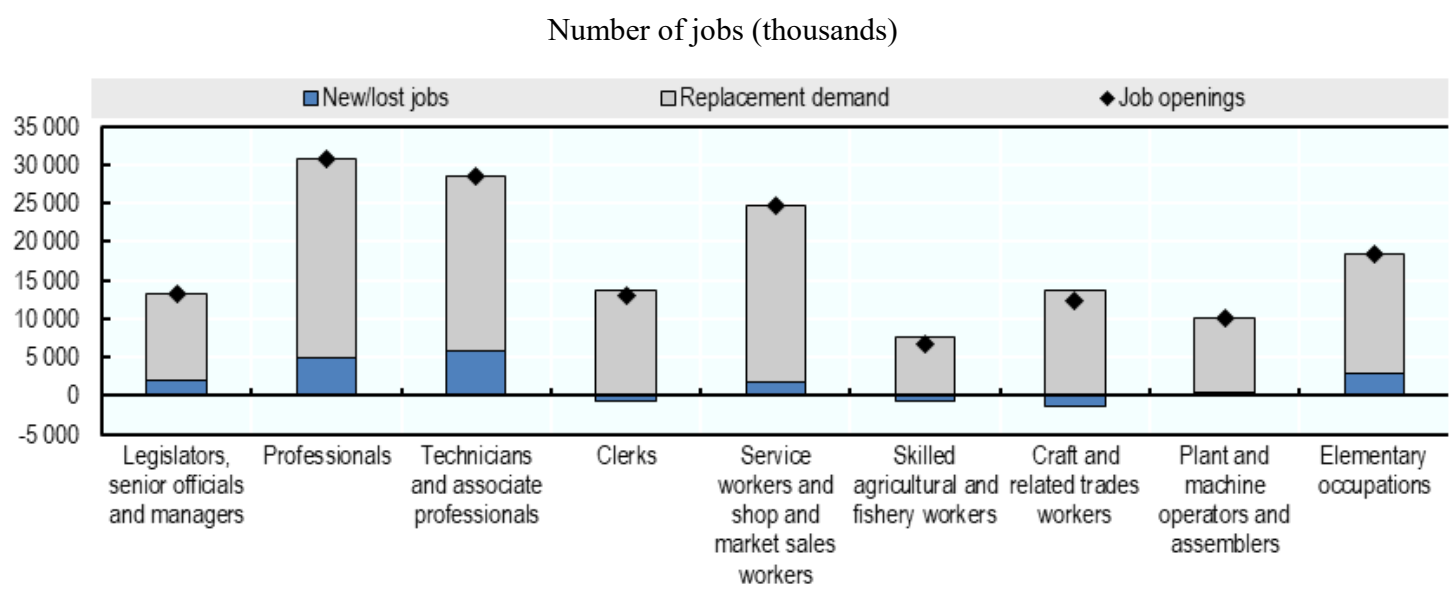

Source: Cedefop and Eurofound (2018[9]).

These patterns show that it will likely become increasingly difficult for VET graduates to find employment in craft and related trades occupations, while sales and service jobs will remain important destinations for them. The strong growth of high-skill occupations, many of which require higher VET or professionally-oriented qualification, underlines the need for solid pathways between mid-level VET and further education as well as for responsive VET programmes at higher education levels (see Chapter Chapter 8. ). The patterns of projected employment growth look largely the same across countries (for broad occupation groups), although there are some notable exceptions. In Ireland, for example, a substantial number of new jobs are projected in crafts and related trades occupations.

\subsubsection{Many of the tasks carried out by VET graduates are at risk of change because of automation}

One of the key drivers of changes in the occupational structure of the labour market is technological progress. Technology has led to automation of certain tasks in the workplace, and this process is expected to continue and contribute to further changes in the occupational composition of the labour market. For example, Heald, Smith and Fouarge (2019 ${ }_{[65]}$ ) estimate that, by 2030 , up to $43.8 \%$ of employment may be lost to automation compared to the baseline Cedefop forecasts that are shown in Figure 7.3. Moreover, some of the occupations that employ many VET graduates, like craft and related trades occupations, have a relatively high risk of automation. ${ }^{43}$ According to Heald, Smith and Fouarge (2019[65] $)$, automation could lead to the loss of up to one fourth of craft and related trades jobs by 2030. On the other hand, some other typical VET occupations, like sales and service workers, have a much lower risk of automation (and hence a lower expected employment loss: up to $-21 \%$ by 2030 according to Heald, Smith and Fouarge (2019[65])). Jobs in the health and personal care sector generally have a low risk of automation, and many medium-level VET programmes and especially higher VET programmes prepare students for these jobs. Chapter 4. already showed that in most countries the difference in

43 This can be seen more clearly in Figure A C.1 (in annex), which shows the risk of automation by occupation, as well as the share of general, vocational and tertiary education in each occupation. 
risk of automation between VET and general education graduates is small, but that their risk is substantially higher than that faced by tertiary education graduates.

Differences in the risk of automation between VET and other graduates can be explained by the fact that these graduates work in different occupations (which have different risk of automation), but also by the fact that they carry out more or less automatable tasks in the same occupations. Figure 7.5 shows the importance of these two components in explaining the difference in the average risk of automation between VET and general education graduates (Panel A), between VET and tertiary education graduates (Panel B), and between VET graduates and those without an upper secondary education degree (Panel C).

In those countries that show a noticeable difference in the average risk of automation between VET and general education graduates, there is a mixed pattern in the relative importance of the within and between components. As Panel A shows, in countries where VET graduates have a higher risk of automation than general education graduates (i.e. France, Slovak Republic, Lithuania, Greece and the United Kingdom), the difference can be explained both by differences in the occupational composition (i.e. the between component) and differences in the tasks carried out within the same occupations (i.e. the within component). On average in these five countries, both effects are equally important. In countries where VET graduates face a lower risk of automation then general education graduates, the pattern is much less clear. Only in Ireland, New Zealand and the United States do both effects contribute to explaining the difference, with the within component being the most important. In other countries, one of the two components contributes negatively to explaining the difference in the risk of automation. In Denmark and Korea, for example, VET graduates are in fact employed in less automatable occupations than general education graduates (i.e. the between effect is negative), but the overall difference is positive because VET graduates carry out more automatable tasks within the same occupations (i.e. a larger positive within effect).

When comparing VET and tertiary education graduates (Panel B), the pattern is clearer. The between effect accounts for two thirds of the difference across all countries. The risk of automation is indeed considerably higher in some of the typical VET occupations, such as building workers, metal and machinery workers, than in the high-skill occupations held by tertiary education graduates (see Figure A C.1 in Annex). The remaining one third of the difference can be explained by within occupation differences. This component accounts for more than $50 \%$ of the difference in Japan, Italy, Turkey and the Slovak Republic, implying that in these countries VET graduates carry out very different tasks than tertiary education graduates employed in the same occupation - i.e. they carry out fewer high-level cognitive tasks (complex problem solving) and social interaction tasks (advising, negotiating, influencing), all of which reduce the risk of automation. By contrast, in the United States, Mexico, New Zealand and the Netherlands, VET graduates are engaged in less automatable tasks compared to tertiary education graduates in the same occupations, which explains the negative contribution of the within component in those countries.

Finally, the comparison between VET graduates and those without an upper secondary degree shows that on average, the lower automation risk faced by VET graduates can be explained to the same extent by the within component and the between component. Nonetheless, in some countries, like the United States, Ireland and the United Kingdom, the difference in automation risk can almost entirely be explained by VET graduates working in less automatable occupation than those without an upper secondary education degree (i.e. the between effect), while in others (e.g. Mexico, Czech Republic) the 
difference comes mainly from a different set of tasks within the same occupations (i.e. the within effect).

Figure 7.5. Decomposition of difference in automation risk between VET and other graduates
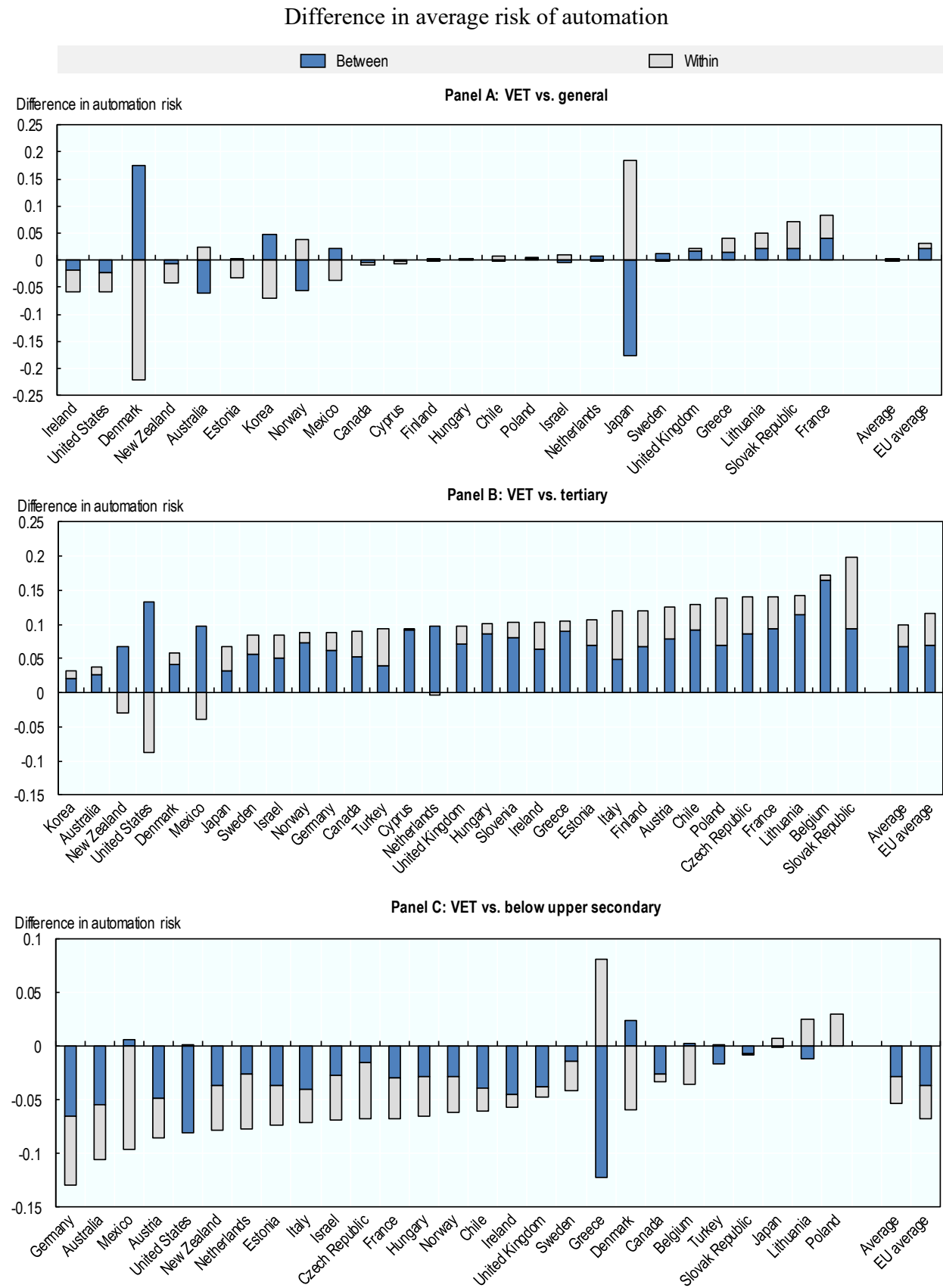

Note: Includes employed individuals aged 16 to 34 not in formal education. The height of the bar equals the risk of automation of VET graduates minus the risk of automation of the reference group. The between component measures the fraction of the total difference that can be attributed to differences in the occupational composition of employment. The within component measures the fraction of the total difference that can be attributed to differences in the tasks carried out within the same occupation. Belgium refers to Flanders only, the United Kingdom to England and Northern Ireland.

Source: Authors' calculations using the OECD Survey of Adult Skills (2012, 2014, 2017). 
Differences in the risk of automation are the result of differences in the frequency of carrying our bottleneck tasks, i.e. tasks that are difficult to automate. Figure 7.6 zooms in on the frequency at which the different graduates carry out these bottleneck tasks. With the exceptions of Dexterity and Selling, all bottleneck tasks are carried out more often by tertiary education graduates than by VET graduates. The biggest differences are found for influencing, complex problem-solving, teaching and negotiating, for which tertiary education graduates report frequent use much more commonly. Differences between VET and tertiary education graduates are significant even when controlling for occupation, industry and personal characteristics (including skills), which is consistent with the above finding that the within component is important for explaining differences in the risk of automation. When adding these controls, the difference between VET and general education graduates is only significant for dexterity (more often used by VET graduates), and influencing, negotiating and selling (less often carried out by VET graduates). Differences between VET graduates and those without an upper secondary degree are always significant, with VET graduates carrying out all the bottleneck tasks more frequently compared to similar graduates without an upper secondary degree employed in the same occupation and industry.

\subsection{Conclusion}

The demand for skills is changing under the impulse of global megatrends, and this could substantially alter the employment outlook of certain occupations. This chapter shows that some of the occupations that generally employ large numbers of VET graduates, and also some occupations that have particularly large shares of VET graduates among their young workers, are facing excess supply in the labour market. This means that VET graduates with skills corresponding to those jobs might face poor prospects in the near future. However, not all of those important occupations for VET graduates are in surplus, and some, like metal and machinery workers and electrical and electronic trades workers, are actually facing hiring difficulties in many countries.

In the next ten years, employment growth is projected to be strongest for professionals and technicians, followed by service and sales jobs, elementary occupations and managers. On the other hand, employment levels are expected to decline for craft and related trades jobs. As the latter is an important occupation group for VET graduates, this suggests that it might become increasingly difficult for graduates specialised in those fields to find employment matching their skills if VET systems do not adapt. Nonetheless, job openings will still be created in these occupations to satisfy replacement demand. One of the key drivers of these projected changes is technological progress, and this chapter shows that many VET graduates are in jobs that have a substantial risk of automation. This probability of automation is similar for VET and general education graduates, and substantially higher than among tertiary education graduates. Graduates without an upper secondary education degree are expected to be most strongly affected by changes due to automation. In New Zealand, Germany and the United States, VET graduates have a substantially lower risk of automation than graduates without an upper secondary degree, while at the same time the difference compared to tertiary education graduates is relatively small. This shows that VET systems in these countries do a particularly good job in preparing students for tasks with low risk of automation (i.e. bottleneck tasks, including high-level cognitive tasks and social interaction tasks) relative to those without an upper secondary degree.

These findings show that the labour market for VET graduates will continue to be impacted by structural changes. As employment growth is projected to be slowest in middle-skill 
occupations, and many of those occupations are already facing surpluses, VET graduates from upper-secondary and post-secondary non-tertiary education might increasingly end up in low-skill jobs unless VET systems are able to respond to changing skills needs. Moreover, the estimates for the risk of automation show that technology might only displace a relatively small number of workers, but that it could potentially have a large impact on job content in many different types of jobs. VET and general education graduates are estimated to face a similar risk of automation, and much of the final impact on labour market outcomes will depend on their adaptability. 


\section{Figure 7.6. Frequency of carrying out bottleneck tasks, by education}

$\%$ of employed graduates

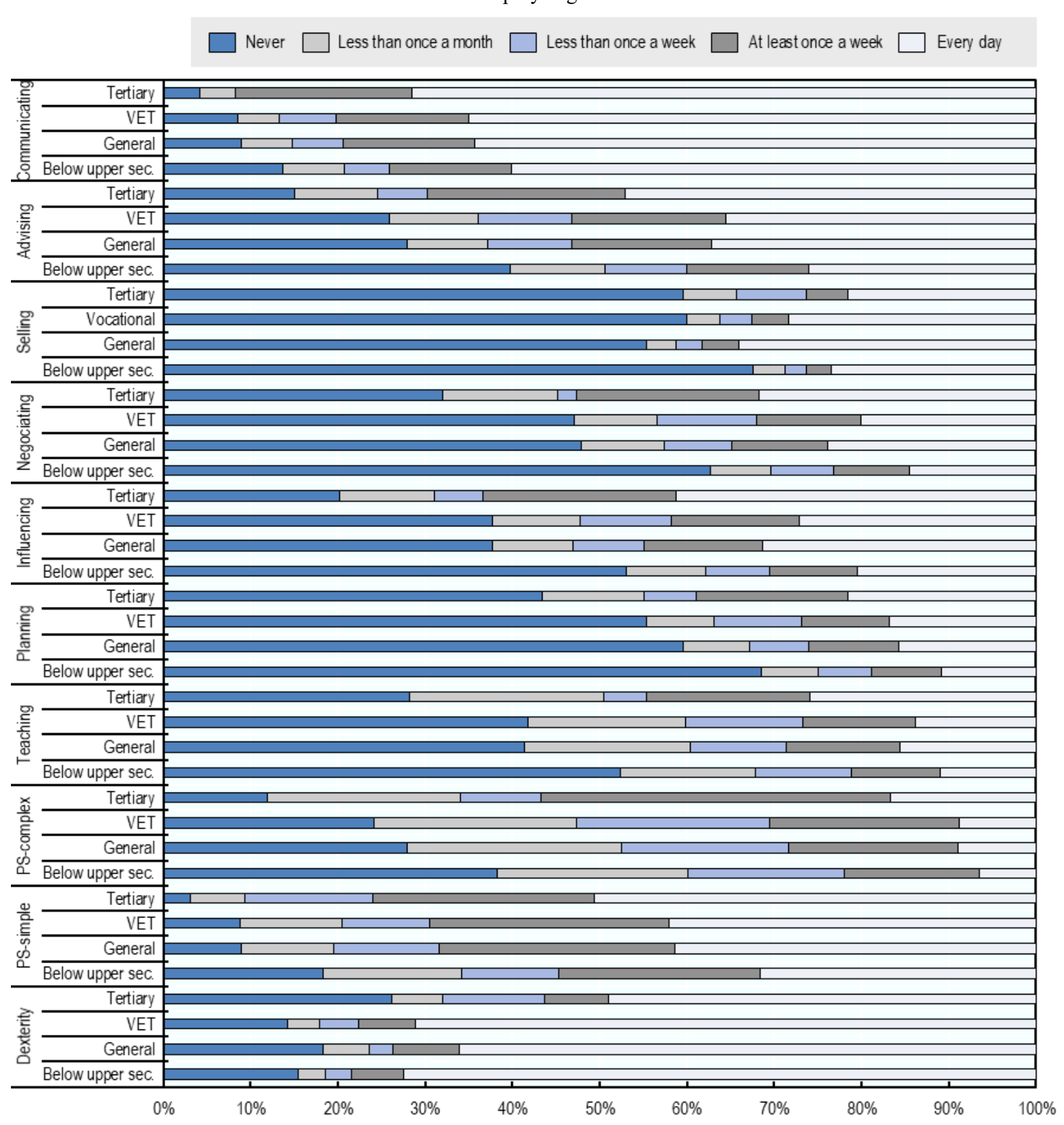

Note: Includes employed individuals aged 16 to 34 not in formal education. Data refer to the unweighted average of OECD countries. PS is short for problem-solving.

Source: Authors' calculations using the OECD Survey of Adult Skills $(2012,2014,2017)$ 


\section{Chapter 8. Policy directions for future-ready vocational education and training}

As the demand for skills is changing and many of the jobs that VET typically prepares students for are expected to undergo substantial changes, several aspects of VET systems may need to be re-engineered to ensure that they are future-ready. This chapter builds on the evidence presented in previous chapters to provide policy pointers for making VET systems more responsive and resilient in a changing world of work.

\subsection{Creating responsive VET systems}

\subsubsection{Strong coordination between VET systems and social partners is crucial}

With many of the jobs commonly targeted by VET undergoing substantial changes because of structural factors such as technological change, VET programmes need to be responsive, so that they remain relevant for students and employers. In responsive VET systems, existing VET programmes are updated in a timely way to reflect changing needs in the labour market, and new programmes are created when there is sustained demand for them. Strong coordination between the VET system and the world of work allows for a better understanding of how jobs and skill needs are changing and how VET systems could potentially react to these changes. Strong ties between VET providers and employers also facilitates the implementation of work-based learning.

Social partners can be involved in different aspects of the VET system. According to KOF Swiss Economic Institute (2016[31]), engagement can take place in the curriculum design phase, the curriculum application phase and the curriculum feedback phase. In the curriculum design phase employers can be involved in setting qualification standards, as well as in the development of student evaluation guidelines. Employer involvement in the application phase mainly happens through the provision of work-based learning, but employers can also be involved in other areas, such as quality assurance of work-based learning, cost-sharing agreements, the provision of equipment and teachers, and the inclusion of a workplace component in student evaluations. Finally, in the feedback phase, employers can share information about student outcomes and skill needs to feed into the re-design of curricula, and they can be involved in determining the optimal timing for curriculum re-design.

Among a range of countries that are deemed to have well performing VET systems, Austria, Switzerland, Denmark and Germany are found to score highest on employer engagement across the different dimensions (KOF Swiss Economic Institute, 2016[31]). While in Austria, Switzerland and Germany employer engagement is the strongest in the curriculum application phase (e.g. through the delivery of apprenticeship programmes), in Denmark engagement is stronger in the design and feedback stages than in the application stage. When looking at the detailed processes in which employers can be involved, the findings suggest that the main features of VET in top performing countries are that employers are involved in (i) setting qualification standards, (ii) deciding when an update needs to happen, and (iii) setting the examination form, but also that students spend most of their time in the workplace instead of the classroom. 


\section{Box 8.1. Keeping VET regulation up to date in Germany}

In Germany, training for each recognised vocational occupation is regulated through a vocational education and training regulation. It sets out the duration of vocational education and training, the knowledge, skills and abilities that need to be acquired through training, a chronologically ordered training plan and assessment criteria. Existing education and training regulations are updated regularly according to a clearly specified process:

1. Social partners or the Federal Institute for Vocational Education and Training (Bundesinstitut für Berufsbildung, BIBB) make a case for updating to the responsible Ministry, typically the Ministry of Economy and Technology.

2. The Ministry agrees key parameters of the new/updated education and training regulation with key stakeholders.

3. The BIBB develops the regulation in collaboration with experts nominated by the social partners within one year. The education ministries of the federal states develop school-based elements of the dual vocational education and training.

4. A council of representatives of the national and federal state level signs-off on the new/updated regulation.

In the period 2006-2015, 130 out of the 328 vocational education and training regulations and their content were modernised and 19 additional regulations for new occupations were created. The speed of adaptation is increasing, according to the BIBB.

Updates of existing education and training regulations often reflect technological advances in the occupation. For example, the regulation for stonemasons and stone sculptors was updated in 2018 to be in line with the increased use of computer-controlled machines to organise the processing of natural stone more efficiently and to offer new products. Many of the new regulations concern ICT and electronics occupations.

Source: (OECD, 2019[66]), (BIBB, 2017[67]; BIBB, 2018[68])

Coordination between the VET system and social partners can happen at different levels and can be organised in various ways. In several countries, sector-level bodies have been established to bring together the key stakeholders within each sector. These bodies are often involved in analysing the skill needs of their sector and coordinating with relevant actors in the education and training field. In Denmark, for example, around 50 national trade committees (faglige udvalg) provide advice on specific VET qualifications relevant to their sector and on the content, structure, duration and evaluation of programmes and courses. The committees monitor the skills development in the labour market and, on that basis, recommend changes to existing programmes, the establishment of new VET programmes or the discontinuation of outdated VET programmes. Employers and employees are equally represented in the Danish trade committees (Cedefop, 2017[69]; Ministry of Education, $\left.2008_{[70]}\right)$. Coordination between VET institutions and labour market actors is also important at the local level, especially in the implementation of apprenticeship programmes. In the United Kingdom, for example, the Greater Manchester city region created an Apprenticeships Hub that aims to improve information and guidance services for young people, build capacity among education providers, and engage employers (OECD/ILO, 2017 [71]). 


\subsubsection{Further expansion of and easy access to higher (vocationally oriented) education needs to be developed}

Employment in high-skill occupations is expected to continue to increase at a faster pace than in medium-skill occupations. In Europe, the sectors that are projected to have the strongest employment growth in the next decade are $\mathrm{R} \& \mathrm{D}$, consulting services, computer programming and advanced manufacturing (Cedefop and Eurofound, 2018 ${ }_{[9]}$ ). These changes imply that there is an increased need for higher-level vocationally oriented qualifications (at ISCED levels 5 and above) and for easy pathways between medium-level VET and these higher-level qualifications.

There has been expansion and diversification of vocationally oriented education and training offered at higher levels in European countries over the last two decades. These vocationally oriented programmes include programmes in professional higher education and higher VET programmes that fall outside of the typical higher education system (but are classified in national qualification frameworks at the same level as higher education qualifications). ${ }^{44}$ Participation has increased and various forms of programmes and qualifications are offered. This is particularly the case for professional higher education, but less evident for higher VET. The profiles of vocationally oriented programmes and qualifications at higher levels often include both academic and vocational components, and on-the-job learning has increasingly been integrated in these programmes. (Cedefop, 2019 [72])

At the same time, countries have opened up higher education to people with vocational qualifications and/or with work experience, but actual use of this non-traditional access route is still relatively low, also in professional higher education (Cedefop, 2019 ${ }_{\text {[72] }}$ ). In addition to helping meet the demand for high-level skills, effective learning pathways can help increase the attractiveness of VET, support lifelong learning, and reduce inequalities and promote social inclusion and mobility (Field and Guez, 2018 ${ }_{[73]}$ ). In practice, many barriers hinder smooth pathways between mid-level VET and higher education, including fragmented education systems with limited transparency, limited development of general skills in mid-level VET to be successful in higher education, and a lack of flexibility in higher education programmes. Box 8.2 describes how some countries use bridging courses to prepare VET students for entry into higher education.

To facilitate the transition between mid-level VET and higher education, Field and Guez $\left(2018_{[73]}\right)$ recommend three guidelines. First, education systems need to be transparent, so that the content and level of VET programmes is clear for all stakeholders. This involves the development of a clear national qualifications framework that allows for an easy mapping of VET qualifications onto the framework's levels, support for credit recognition agreements linked to learning outcomes, the development of a system of recognition of prior learning (RPL), and the provision of relevant career guidance. Second, initial VET needs to be designed to support further education and training, including by providing a

\footnotetext{
${ }^{44}$ As described by Auzinger, Ulicna and Messerer $\left(2016_{[107]}\right)$, there is no consensus on the definition of higher Vocational Education and Training. According to the broad definition of higher VET, this field covers all professional qualifications at level 5 and above in the European Qualifications Framework, including those covered by the European Higher Education Area (EHEA). This means mostly short cycle, Professional Bachelor and Master degrees as well as apprenticeships at these levels. According to the more narrow definition, higher VET covers only those professional qualifications that are fully outside the EHEA. This concerns both qualifications from the formal education and training system but also those that are awarded outside it.
} 
sufficient range of general knowledge and skills, and should be augmented with bridges to more advanced programmes. Third, obstacles to the participation in post-secondary education need to be addressed. This can be achieved by encouraging higher education institutions to broaden their entry requirements, providing financial support to those who need it, developing short-cycle programmes, and meeting the needs of adult students. As a foundation for subsequent pathways, it needs to be ensured that initial VET is of high quality, that it is inclusive and serves equity, and reflects the needs of the labour market through engagement with the world of work.

\section{Box 8.2. Facilitating access to higher education through bridging courses}

\section{Preparatory training for special entry exams in Austria}

In Austria, graduates from the dual system and 3-4 year VET schools can enter universities and Fachhochschulen, by completing special exams (Berufsreifeprüfung). Candidates for this special exam usually attend preparatory courses run by the Wirtschaftsförderungsinstitut (WIFI) or Berufsförderungsinstitut (Bfi). Since 2008, apprentices have the option of pursuing a double degree (Lehre mit Matura), combining the occupational qualification and the special higher education entrance degree. In 2018, only around $6 \%$ of apprentices opted for this combined degree. For certain study programmes, VET graduates can conduct a Studienberechtigungsprüfung, i.e. a special exam that grants access to the individual programme.

\section{Transition measures in VET programmes in the Netherlands}

In the Netherlands, many vocational education graduates at the upper secondary level (MBO-4) continue to higher education, as they have direct access to universities of applied sciences (HBO). Five years after graduation, $45 \%$ of them have obtained a HBO degree. However, the transition can be difficult, with a substantial share of students dropping out in the first year or changing programmes. In recognition of these difficulties, several education institutions have put in place initiatives to better prepare the VET students for higher education. These include extra lessons or projects and joint initiatives between the VET institutions and higher education institutions.

\section{One-year bridging programmes in Norway}

In Norway, graduates from the vocational track at the upper secondary level have the option to continue to higher education after a one-year bridging course. This bridging course covers six key academic subjects: Norwegian, English, Mathematics, Natural Sciences, Social Sciences, and History. A similar pathway is also available for adults aged 23 or above who want to enter higher education without a qualification and who have at least five years of work experience (or a combination of education and work experience). For certain higher education programmes, mainly in the engineering field, entry is allowed for vocational qualification holders without going through the bridging programme.

Source: (OECD, 2014[74]), (Dornmayr and Nowak, 2018[75]), (Field and Guez, 2018[73]), (MBO Raad, 2019[76]), (Norwegian Directorate for Education and Training, 2013[77]) 


\subsubsection{VET systems should broaden their scope to non-traditional fields that are facing strong demand in the labour market}

VET provision, and especially apprenticeships, are often focused on a relatively narrow set of occupations and sectors. The popular image of an apprentice is often of working in a skilled trade or craft, such as construction or manufacturing. This accurately reflects the apprenticeship landscape in many countries, where apprenticeships are most common in manufacturing, construction and engineering. Limiting apprenticeships to "traditional sectors" means missing out on the potential benefits of apprenticeships in sectors where most of tomorrow's jobs will be found. Moreover, skilled trade and craft occupations are often perceived as traditionally "male" with limited female participation. As a result, women seeking a vocational qualification mostly pursue school-based programmes and do not benefit from the advantages of apprenticeship schemes. (OECD, 2018 $\left.8_{[78]}\right)$

In recent decades, many countries have sought to diversify the sectoral coverage of apprenticeships in recognition of the potential of apprenticeships as a pathway to a wider range of skilled jobs $\left(\mathrm{OECD}, 2018_{[78]}\right)$. Australia introduced non-trade apprenticeships in the 1980s, and these now outnumber trade apprenticeships. In Switzerland, the three most popular apprenticeship occupations are business and administration, wholesale and retail sales and building and civil engineering. In Germany, the most popular apprenticeship occupations are in the management and retail sectors. In Austria, office, trade and finance is the second largest group of apprentice occupations, with nearly as many apprentices as the machine and metal sector. In England, apprenticeships used to be mostly in traditional trade fields, but since the 1990s service sector apprenticeships have grown strongly. Today it is even possible to pursue an apprenticeship as a policy adviser in the civil service. Box 8.3 gives examples of apprenticeships in one of the fastest growing sectors in many countries, namely the IT sector.

\section{Box 8.3. Preparing VET students for IT jobs}

\section{IT apprenticeships in Switzerland}

In Switzerland, students in the VET system can pursue an IT apprenticeship. This IT vocational training program takes four years to complete. Apprentices spend one to two days per week in a vocational training school and have the choice of three specializations, namely application development, business informatics and systems administration/ engineering. More than $90 \%$ of IT degrees are based on apprenticeships and vocational training. The number of IT apprenticeships is on the rise, increasing with almost 50\% in the period 2006-2017. In 2017, IT featured among the top 5 fields that welcomed the most VET students.

\section{ICT Associate Apprenticeship programmes in Ireland}

In Ireland, new apprenticeship programmes were introduced in 2018 in the fields of software development, network engineering, and cybersecurity. These 2-year apprenticeship training programmes lead to a level-6 qualification (i.e. ISCED-4). In the first six months, students attend full-time off-the-job training and development. In months 7 to 18 , they combine 3 days at work with 2-days off-the job training, while in the last six months they spend 4 days in work and only one day in off-the-job training.

Source: (ICT Formation professionnelle, 2017[79]) (Confédération Suisse, 2019[80]) 


\subsection{Smoothening transitions}

\subsubsection{VET students need to leave the education system with solid foundational skills}

General education, defined as leading to generic knowledge and skills that is not directly relevant to a specific occupation and applicable in most contexts of work and life, is an important part of vocational education and training. It would include numeracy, literacy, science, social studies and civic education. General education is part of effective occupational training: a well-qualified electrician needs to be familiar with basic mathematical and physical laws. Moreover, strong foundational skills can help students in accessing further education and training. General education does not necessarily require classroom settings, and can take place in informal environments and the workplace. (Kuczera and Field, 2018 ${ }_{[81]}$ )

Although there is a lack of internationally comparable information on the split between occupational and general subjects in VET programmes (see Kís (forthcoming ${ }_{[27]}$ ) for a discussion), it is known that countries differ widely in the extent to which they incorporate general education in their VET programmes. In Switzerland, all apprentices receive 2.5 hours per week of teaching in the official language, communication, civic education (including some applied mathematics) and 45 minutes of physical education. This adds up to 120 hours of basic skills education and sports per year (Confédération Suisse, 2006 ${ }_{[82]}$ ). In Germany, apprentices receive 160 hours annually of general education, and this time is divided among subjects such as German, English, sports and economics or social science (Hoeckel and Schwartz, 2010[83] $)$. In Norway, most apprentices spend the first two years of their apprenticeship in full-time school education before moving to a work placement for the remaining two years of their apprenticeship. During the two school-based years apprentices must pursue 588 hours of basic education including Norwegian (or other official language), mathematics, English, science and physical education (Norwegian Directorate for Education and Training, 2018[84] $)$. Conversely, in Australia, the employer-led training packages which define apprenticeships contain a relatively limited amount of general education, and for that reason have been criticised as inadequate (Knight and Karmel, 2011 $\left.1_{[85]}\right)$. In the English apprenticeship system, most young apprentices receive between 50-100 hours of general education, which is less than in many other countries (Kuczera and Field, 2018[81]).

Based on evidence from Swedish and Danish VET graduates, it has been shown that the amount of cognitively challenging subjects at the upper-secondary level gives a lasting imprint on literacy proficiency later in life (Rasmusson et al., 2019[86]). Stronger cognitive skills could help adults in the labour market, by making them more adaptable and facilitating participation in further training opportunities. Hanushek et al. $\left(2017_{[18]}\right)$ indeed suggest that the weaker labour market outcomes of VET graduates later in life could be linked to weaker basic skills and therefore limited adaptability. Nonetheless, other research on the reforms of Swedish VET programmes finds no evidence that having attended a longer and more general vocational program is associated with a reduced risk of experiencing unemployment, nor with a higher probability of entering higher education or higher earnings later in life (Hall, 2012 ${ }_{[87]} ; 2016_{[88]}$ ). The evidence also suggests that these longer VET programmes could have a negative effect on outcomes of students who enter these programmes with low levels of skills, as it increased their probability of dropping out of school (Hall, 2012[87]). 
Finding the right balance between general and vocational subjects is not an easy tasks. Firstly, when reinforcing the general component in VET curricula it should be ensured that this does not have detrimental effects on the motivation of students. Some students might have chosen the vocational track because of negative experiences within a standard school-based setting, and might therefore be demotivated by curricula that have a substantial school-based academic component. One way to potentially overcome this issue is to integrate basic skills with vocational training. In the United States, the Math-in-CTE (career and technical education) programme brings together CTE and math teachers to develop a curriculum map that identifies the CTE concepts and intersecting math concepts that are naturally embedded within the CTE curriculum (OECD, $\left.2010_{[89]}\right)$. Secondly, when adding general subjects to VET curricula results in a longer study duration, the potential benefits of such a reform should be carefully weighed against the expected (opportunity) costs.

Ensuring that VET graduates have strong foundational skills is not the sole responsibility of the VET system, but also of the broader initial education system. Strong foundational skills need to be developed already in the early years of education, before students enter the VET stream. This will help avoid that youngsters entering VET have already accumulated already substantial gaps in foundational skills during their early education years. Inclusiveness of the education system is of crucial importance to ensure that no-one is left behind.

\subsubsection{VET graduates need access to up- and re-skilling opportunities that are responsive to labour market needs}

It is not only important to update the VET system to ensure that new graduates have skills that correspond with labour market needs, but also that graduates have continued opportunities to up-skill and re-skill after entering the labour market. Moreover, many of the people affected by ongoing structural changes are already in the labour market. Ensuring that adults have access to high-quality training opportunities that are aligned with the needs of the labour market, is therefore becoming increasingly important. This is particularly the case for VET graduates, because many of the jobs they are hold are likely to change because of automation. At the same time, VET systems often prepare students for a rather narrow set of jobs, making it potentially more difficult for VET graduates to transition between jobs.

Across OECD countries, $41 \%$ of adults participate in formal or non-formal job-related training in a given year (OECD, 2019[60] ). As discussed in Chapter Chapter 4. , VET graduates participate slightly more in training than general education graduates, but much less than tertiary education graduates. The majority of VET graduates not participating in training report not wanting to do so, which highlights the difficulty of engaging adults in learning. Other commonly stated reasons for not participating include a lack of time and a lack of financial resources.

To facilitate participation in adult learning, training opportunities need to be designed in such a way that they contribute to tackling the barriers faced by adults. For example, to overcome barriers related to time constraints, adult learning programmes should ideally be flexible. This can be achieved by organising training at times that are more convenient for adults, like for example in the evening or on weekends, offering part-time and/or modular programmes. Moreover, as shown Chapter Chapter 4. , only a small share of VET graduates participate in formal training, while many more acquire skills informally or through non-formal training during their (working) life. Formal recognition of these skills can help 
in shortening training programmes and making them more useful by focusing only on those skills that the participant is lacking. Financial constraints can be alleviated by providing financial incentives, such as subsidies, tax credits, loans and allowances.

For training to be able to help individuals develop the right skills, the training offer and content needs to be aligned with labour market needs. Data at the employer-level shows that in European countries there is generally a weak overlap between the skills that employers report as priorities for their future development and the skill that they are training their employees in (OECD, 2019[60]). Moreover, in many countries, a substantial share of training provided is in the area of health and safety, and while this type of training certainly is important, it does generally not help adapt to or prepare for structural changes in the labour market.

The first step in the development of responsive adult learning policies, is the collection of high-quality information on skill needs in the labour market. In virtually all OECD countries, a system of skills assessment and anticipation has been put in place to understand short- and medium-term skill needs. However, policy-makers and other stakeholders in the skill system often face obstacles when trying to use the results from these exercises, including poor communication/sharing of the results and difficulty in translating the (often technical or complex) results into useful information for policy design (OECD, 2016 ${ }_{[90]}$ ). Nonetheless, there are several OECD countries that use information on skill needs to better target their training offer or training incentives, and to provide relevant career guidance services. In Portugal, for example, regional branches of the Public Employment Service (PES) analyse the skill needs in their region, including information on vacancies from the local PES offices, to determine the offer of vocational training within the network of Employment and Vocational Training Centres. In Estonia, employers hiring job-seekers for certain occupations that are found to be in shortage and of growing importance in the labour market can receive training grants (Recruitment Training Grant) to partially compensate for the cost of training the new hires.

Another way in which to use information on skill needs, is to identify those adults who have a high risk of being affected by structural changes in the labour market. Such a strategy allows for interventions, such as career guidance and training, before workers see their jobs restructured or downsized, and therefore contributes to smoother transitions. Box 8.4 provides some examples of this type of strategy.

\section{Box 8.4. Targeting adults at risk of skills obsolescence}

\section{Structural Adjustment Packages help workers in Australian regions or industries with poor} employment prospects

In Australia, Structural Adjustment Packages (SAPs) are provided to assist employees in areas where expectations of future employment opportunities for workers in the industry are low or where large scale closures may impact on the local labour market. Targeted employment assistance under SAPs can involve skills and training components for adult learners. A Stronger Transitions Package was introduced to support individuals in five regions impacted by structural change to transition to new jobs and prepare for the jobs of the future in 2018. The package includes a Pre-retrenchment Skills and Training Support measure, which can provide targeted services such as comprehensive skills assessments; job search preparation; resilience training; language, literacy and numeracy support; digital 
literacy training; financial management information; exploring self-employment options; health and wellbeing support, and industry awareness experiences.

\section{Actors in the Austrian skills system work together to support workers facing structural changes}

In Austria, Outplacement Labour Foundation (Arbeitsstiftung) programmes were introduced by social partners to support workers in the case of structural changes through appropriate labour market policies. These Foundations can be formed by one or multiple employers, but also at the sector and regional level when specific regions or sectors are affected by major staff cuts. The programmes are co-financed by local labour market actors, including the PES and the affected employers. Funding is available to cover training costs, allowances for course-related additional costs, and active job-search assistance and career guidance costs.

\section{Swedish Job Security Councils support employees at risk of dismissal}

Job Security Councils are based on sectoral or cross-sectoral collective agreements, are run by social partners and exist in all sectors of the Swedish economy. They are financed through an employer levy of $0.3 \%$. The councils target workers at risk of collective dismissals, which means their company or part of their company is closing down or has to restructure for technological or economic reasons. In this case, the councils provide a range of services, including advice and guidance, training, financial support and business startup support. The councils typically intervene before a dismissal takes place, to manage the transition to other jobs for between six to eight months. Workers have a dedicated coach and receive personalised services. The councils have a relatively high success rate: $74 \%$ of workers go on to employment or further training and $70 \%$ of those who find work manage to maintain or increase their salary in the process.

Source: OECD (2019[60]; 2019[66])

\subsection{Supporting students and adults in making informed choices}

\subsubsection{Students need access to high-quality career guidance at early stages}

Deciding what to study is not an easy choice, especially not in the context of a rapidly changing labour market. Career guidance services can help students navigate the different options and make informed choices. Evidence suggests that students can have unrealistic career aspirations that do not match with the demands in the labour market (Musset and Kureková, 2018[91]). Many students only consider a limited number of possible occupations, and career guidance could help broadening horizons. Evidence for the Netherlands suggests that recent VET graduates who made extensive use of labour market information to guide their education choice have better labour market outcomes than graduates for whom labour market information was a less important factor in their education choice (Fouarge, Künn and Punt, 2017 [92] $_{\text {). }}$.

Several studies have found that students receive less information about vocational programmes compared to general programmes (Musset and Kureková, 2018 [91]). This is partly linked to the poorer image of vocational programmes in many countries. A European opinion survey on VET showed that $50 \%$ of people who chose the general track did not receive information about VET options when making their education decision (Cedefop, $2017_{[93]}$ ). While the majority of survey respondents had a generally positive image about 
VET, they also tend to agree that general education has a more positive image than VET, that VET is mainly for students of lower academic performance, and that obtaining a VET qualification is usually easier than obtaining a qualification in general education. Nonetheless, those who did chose the vocational track are generally more satisfied with their learning outcomes than general education graduates.

Helping students understand the world of work is a crucial component of effective career guidance, and therefore close engagement between schools and employers is important. PISA data show that most of the career guidance that students receive happens independently of employers, e.g. talking to career counsellors, completing questionnaires, or using the internet to find information about education and career choices. Work visits or job shadowing activities are the most commonly observed career guidance services that involve employer engagement (37\% of students), followed by career fairs $(28 \%)$ and internships (27\%) (Musset and Kureková, 2018[91]). To reduce the barriers for employers to engage in career guidance activities, schools need to help them understand the benefits of these activities and make it easy for them to become involved. In the United Kingdom, the Inspiring the Future platform matches schools and employers, see Box 8.5.

\section{Box 8.5. Inspiring the Future: Matching schools with the world of work in the United Kingdom}

Inspiring the Future is a secure website where schools, colleges and volunteers from the world of work connect. It is based on the concept of online match making, deploying software used by leading companies for online shopping, to provide secure, trusted, just-in-time, and cost-free interactions between schools and the world of work.

Volunteers from various professions pledge one hour a year to volunteer in a state school or college near where they live or work to talk to young people about their job and career route. In addition, volunteers can select a number of areas of expertise that might be of interest to students, such as how maths is used at work, financial literacy, languages, or engineering and technology. Teachers select and invite people who best meet the needs of their students from a range of sectors and professions.

The project was developed by a non-profit charity in partnership with a range of stakeholder, including employers, trade unions, education, government, third sector and intermediaries. It was preceded by research to identify what are the barriers in better linking employers and schools. To date, some 275000 invitations have been issued by teachers in thousands of schools to a pool of 50000 volunteers.

Source: Adapted from (Musset and Kureková, 2018[91])

In summary, effective career guidance is characterised by a set of general principles. First, regular opportunities need to be available for young people, from primary education onwards, to reflect on and discuss their prospective futures. Second, students need to be able to consider the breadth of the labour market and particularly occupations which are of strategic economic importance, newly emerging and/or likely to be misunderstood (such as the skilled trades). Third, school-wide approaches need to be undertaken, bringing on board career guidance specialists, but also teachers and school leaders, as well as parents, and people in work. Fourth, easy access to trustworthy labour market information and advice/guidance from well-trained, independent and impartial professionals in advance of key decision points needs to be available. Fifth, it needs to be recognised that the ways in which young people think about jobs and careers are shaped by parental influence, their 
social background and sense of identity. These information asymmetries about specific professions need to be addressed and gender and ethnic stereotyping need to be challenged. Sixth, young people from the most disadvantaged backgrounds need to be targeted for the greatest levels of intervention. (Musset and Kureková, 2018 [91])

\subsubsection{VET graduates need effective career guidance throughout their working lives}

Career guidance is not only important to help youngsters make a study choice; helping individuals to make choices regarding their education, training and career remains important throughout their working lives. Effective career guidance is certainly of importance for VET graduates, because they are likely to need to up- or reskill during their working life, due to the structural changes that some of their typical jobs are facing.

Career guidance for adults can help them understand the skills they already have, as adults have generally acquired skills informally or non-formally in addition to the formal qualifications they hold. It also helps adults understand which skills they want or need to develop further, and navigate available learning opportunities to develop those skills. However, there is evidence to suggest that adults are not always able to recognise the need to develop their skills further (Windisch, 2015[94]). Public awareness campaigns may promote the benefits of seeking career or training advice, advertise specific career guidance services, or reach out to underrepresented or vulnerable groups at risk of job change or skill obsolescence. The Institute for Adult Education in Slovenia, for example, has been organising an annual lifelong learning week since 1996, to improve knowledge, understanding and implementation of adult learning opportunities and guidance through thousands of events that are organised throughout the country (Republic of Slovenia, 2019 [95]).

According to data from the European Adult Education Survey, less than 30\% of adults look for information on learning possibilities (OECD, 2019[66]). The share is lower among adults without a tertiary education degree. To reach the widest possible audience, career guidance should go beyond providing its services to those who ask for it. Information on learning opportunities can be delivered through different media channels, such as TV, radio, print, online and social media, as well as include outreach work through events, existing networks or direct mail. In Argentina, for example, the Hacemos Futuro programme reaches out to community leaders via WhatsApp, who in turn inform their target group about upcoming training offers (OECD, 2019[60] $)$. In the United Kingdom, Union Learn Representatives (ULRs) are trade union members who analyse workers' learning or training needs, guide them towards or arranging and supporting learning activities, and consult employers about such activities (UnionLearn, 2018[96]).

Moreover, career guidance should be available and accessible to all. For instance, career guidance services are not always easily accessible or even available for employed adults, and employed adults are less likely to access career services than are unemployed adults (OECD/European Commission, 2004 $\left.{ }_{[97]}\right)$. Access to career guidance can be improved by making public employment services (PES) accessible to employed adults, or by encouraging collaboration between employers, trade unions and training providers in providing quality guidance services. For example, in Estonia, labour market training provided through the PES is since 2017 also available for employed adults, particularly those at risk of skill obsolescence or unemployment due to their health status, age, or low language skills or educational qualifications $\left(\mathrm{OECD}\right.$, forthcoming $\left.{ }_{[98]}\right)$. In France, a network 
of career guidance providers are accessible to all employed adults and job seekers free of charge, see Box 8.6.

\section{Box 8.6. Career guidance for adults in France}

In France, workers and jobseekers have access to free and personalised career guidance services, under the Conseil en Évolution Professionnelle (CEP). Services are delivered by certain national agencies (including the Public Employment Service, Pôle Emploi) and a range of private providers. Guidance is adapted to the needs of the workers or job-seekers, and is generally organised in three stages:

- An individual meeting to analyse the person's professional situation

- Advice to support the elaboration of a person's professional development project

- Support in putting the person's professional development project in practice

The guidance services help participants understand their professional situation, the evolution of employment and jobs in France (and the specific region), as well as the possible tools to help advance one's professional development project. Guidance counsellors help participants in realising their project, by proposing -for example- training pathways and options for financing their project.

The CEP was introduced in 2014, and participation increased gradually over time. While the policy covers both jobseekers and workers, the large majority of participants are jobseekers (83\% in 2017). In an effort to reach more workers, the CEP received additional financing earmarked for services to workers, and a range of private providers that have close ties to the world of work were selected to deliver the services (instead of the national agency that was in charge of service provision to workers before the reform). This reform is part of a wider set of reforms to the adult learning system introduced in 2018.

Source: (République Française, 2019[99]), (Ministère du Travail, de l'Emploi, de la Formation professionnelle et du Dialogue Social, 2016[100])

For those individuals who do know where and how to find career guidance, it is important to give holistic and personalised advice. Effective career guidance takes into account a person's personal circumstances, skills, abilities and preferences, and navigates available relevant learning possibilities as well as other services to overcome barriers to participation (e.g. limited finances, lack of time due to family commitments or distance to the training location). This, however, requires skilled caseworkers, who have sufficient time and resources to provide tailored assistance to each individual. For instance, Belgium (Flanders), Czech Republic, Iceland, Lithuania, the Netherlands and Slovenia implemented the GOAL (Guidance and Orientation for Low-Educated Adults) project between February 2015 and January 2018, in which one-to-one and face-to-face guidance was provided to low-skilled adults, custom-fit to the clients' needs and personal circumstances (Carpentieri et al., 2018 $\left.8_{[101]}\right)$. In Austria, Bildungsberatung Österreich offers independent and free counselling for adults on education and training opportunities in all Austrian federal states. Depending on the federal state, adults can choose from a range of modes to receive guidance, including face-to-face, on the phone or online via skype or chat, and in which of 16 available languages they would prefer to receive their guidance (OECD, 2019 [102]).

Finally, career guidance should be an integral part of the adult learning system. For instance, career guidance could be included in public funding for education and training, 
and employers need to value the importance of career guidance, for example by making expenditures on career guidance eligible for training levy schemes (OECD/European Commission, 2004 $[97])$.

\subsection{Safeguarding job quality}

As low-wage jobs, including certain sales and service jobs and elementary occupations, are expected to continue to grow, some VET graduates will inevitably end up in these jobs. While this is not a problem per se, especially since some VET programmes directly prepare students for these jobs, the quality of these jobs needs to be safeguarded. As discussed in Chapter Chapter 4., VET and general education graduates have roughly the same outcomes in many aspects of job quality, but often they do worse than tertiary education graduates. Moreover, while VET graduates seem to have an advantage relative to general education graduates at the start of their career in certain aspects of job quality, such as access to permanent contracts and supervisory responsibilities, this advantage decreases over time. Therefore, policies and practices that foster job quality are important, as are education and training policies that can ensure that workers in low-quality jobs can progress in their career.

Wages are an important aspect of job quality, and while VET graduates earn slightly higher wages than general education graduates, the gap with tertiary education graduates is large, even when working in similar jobs. Real wages are the most direct mechanism for transmitting the benefits of productivity growth to workers and their families, but in the past two decades, productivity gains no longer appear to translate into broadly shared wage gains for all workers. Labour market policies and institutions can support a fairer sharing of productivity gains both by affecting the relative cost of labour - and thereby the degree to which capital is substituted for some types of labour - and by influencing the distribution of product market rents. A statutory minimum wage can help ensure that workers at the bottom of the wage ladder also benefit from growing economic prosperity. When minimum wages are moderate and well-designed, adverse employment effects can be avoided. (OECD, 2018 $[103])$

Collective bargaining institutions and social dialogue can help promote a broad sharing of productivity gains, including with those at the bottom of the job ladder, provide voice to workers and endow employers and employees with a tool for addressing common challenges. To promote good quality jobs for all in a changing world of work, collective bargaining systems have to have wide coverage, while providing sufficient flexibility to firms. Graduates without a tertiary education degree are more likely to be employed in small firms, and these are the firms that have the lowest trade union density. (OECD, 2019 [104]

Productive and healthy work environments are also crucial components of job quality, and this can be promoted through policies preventing and addressing work-related health and safety risks. As VET graduates are more likely to be in physically demanding jobs than general education graduates, they might be more exposed to physical health risk. The involvement of social partners is crucial to ensure the effective implementation of incentives, regulation and guidelines in the area of health and safety. A working environment that is conducive to career development, work-life balance and good physical and mental health will help avoid that difficulties cumulate over the working life. Indeed, health problems and the difficulty of combining work and family life are among the main reasons for withdrawing from the labour force, especially for older workers and women. While working conditions and work organisation are primarily determined by employers, 
often together with trade unions or other forms of worker representation, policies and institutions can provide employers with incentives and tools to improve them. (OECD, $\left.2018_{[103]}\right)$

Finally, exposure to high-performance work practices (HPWP) can help workers make better use of their skills, contributing to higher wages and job satisfaction (OECD, 2016 $6_{[58]}$ ). As discussed in Chapter Chapter 4., VET and general education graduates have the same exposure to HPWP, but they are lagging compared to tertiary education graduates. At the same time, VET graduates make less intensive use of their literacy, numeracy and digital problem-solving skills in the workplace than general and tertiary education graduates with similar skill levels. While the adoption of HPWP is ultimately the employer's decision, it can be facilitated and encouraged through specific policies. Many countries have undertaken policy initiatives to promote better skills utilisation through workplace innovation. The background to most interventions is the recognition that many firms, if offered expert advice and encouragement to adopt more effective managerial practices, can better utilise existing skills and reap the productivity gains, increasing returns to training for all. Many of these initiatives have focused on raising awareness of the benefits of better skills use, disseminating good practice and sharing expert advice. Employment New Zealand has published a Flexible Work Toolkit to help SMEs understand and manage flexible work with practical tips and tools. Tax incentives and subsidies can also be leveraged to incentivise and support firms in adopting HPWP, especially considering that some firms may not have the incentive or financial capacity to promote workplace innovation. The Liideri programme of the Finnish Funding Agency for Technology and Innovation (Tekes) funds projects within companies to renew their operations through developing management principles and forms of working and actively utilising skills and competencies of their personnel. (OECD, 2019 $\left.9_{[60]}\right)$

\subsection{Conclusion}

In an era of fast changing skill demand, VET has the potential to contribute to a responsive education system. While all education groups will be affected by changes in the labour market, the impact is expected to be stronger for low- and middle-skilled workers, as they are often employed in jobs that are facing declining demand or undergoing substantial changes in their content and the way work is organised.

For VET to maintain its strong role in contributing to student engagement and facilitating the transition from school to work, VET systems need to be responsive and students need to have skills that foster their adaptability in a changing world of work. This chapter discussed policy directions in these dimensions, highlighting good practice examples from OECD countries. Responsive VET systems need close ties with the world of work to understand and adapt to the realities in the labour market. Moreover, with employment growth projected to be strongly concentrated in high-skill jobs, such as associate professionals and technicians, VET graduates need easy access to further education and training, including to higher vocational programmes. Expanding VET to higher level of qualifications and to new fields that are facing strong labour market demand can also contribute to the responsiveness of the system. To ensure that VET graduates are adaptable in the labour market, they need solid foundational skills and ample opportunities to up-skill and re-skill to keep their skills up-to-date. Helping students and adults make informed education, training and career choices will further improve their labour market outcomes by better aligning supply and demand. Finally, safeguarding job quality remains a key issues, especially in a polarised labour market. 


\section{References}

Adalet McGowan, M. and D. Andrews (2015), "Labour Market Mismatch and Labour Productivity: Evidence from PIAAC Data”, OECD Economics Department Working Papers, No. 1209, OECD Publishing, Paris, https://dx.doi.org/10.1787/5js1pzx1r2kb-en.

Agodini, R. and J. Deke (2004), The Relationship Between High School Vocational Education and Dropping Out, Mathematica Policy Research, Princeton.

Arntz, M., T. Gregory and U. Zierahn (2017), "Revisiting the risk of automation", Economics Letters, Vol. 159, pp. 157-160, http://dx.doi.org/10.1016/J.ECONLET.2017.07.001.

Arulampalam, W., P. Gregg and M. Gregory (2001), "Unemployment Scarring”, The Economic Journal, Vol. 111/475, pp. F577-F584, http://dx.doi.org/10.1111/1468-0297.00663.

Autor, D. (2015), "Why Are There Still So Many Jobs? The History and Future of Workplace Automation", Journal of Economic Perspectives, Vol. 29/3, pp. 3-30, http://dx.doi.org/10.1257/jep.29.3.3.

Autor, D. and D. Dorn (2013), "The growth of low-skill service jobs and the polarization of the US Labor Market”, American Economic Review, Vol. 103/5, pp. 1553-1597, http://dx.doi.org/10.1257/aer.103.5.1553.

Autor, D., L. Katz and M. Kearney (2006), “The Polarization of the U.S. Labor Market”, American Economic Review, Vol. 96/2, pp. 189-194, http://dx.doi.org/10.1257/000282806777212620.

Auzinger, M., D. Ulicna and K. Messerer (2016), Study on Higher Vocational Education and Training in the EU, European Comission - Directorate-General for Employment, Social Affairs and Inclusion, http://dx.doi.org/10.2767/421741.

Béduwé, C. and J. Giret (2011), "Mismatch of vocational graduates: What penalty on French labour market?”, Journal of Vocational Behavior, Vol. 78/1, pp. 68-79, http://dx.doi.org/10.1016/j.jvb.2010.09.003.

BIBB (2018), New training year begins with 25 updated occupations, https://www.bibb.de/en/pressemitteilung_82427.php (accessed on 7 November 2019).

BIBB (2017), Training regulations and how they come about.

Bishop, J. and F. Mane (2004), "The impacts of career-technical education on high school labor market success", Economics of Education Review, Vol. 23/4, pp. 381-402, http://dx.doi.org/10.1016/j.econedurev.2004.04.001.

Broughton, A. et al. (2018), The experiences of individuals in the gig economy, Department for Business, Energy \& Industrial Strategy.

Brunello, G. and L. Rocco (2017), "The effects of vocational education on adult skills, employment and wages: What can we learn from PIAAC?", SERIEs, Vol. 8/4, pp. 315-343, http://dx.doi.org/10.1007/s13209-017-0163-z. 
Carpentieri, J. et al. (2018), GOAL: Final cross-country evaluation report, https://adultguidance.eu/images/Reports/GOAL final cross-country evaluation report.pdf (accessed on 9 October 2019).

Cazes, S., A. Hijzen and A. Saint-Martin (2015), "Measuring and Assessing Job Quality: The OECD Job Quality Framework", OECD Social, Employment and Migration Working Papers, No. 174, OECD Publishing, Paris, https://dx.doi.org/10.1787/5jrp02kjw1mr-en.

Cedefop (2020), "On the way to 2020: data for vocational education and training policies", Cedefop Research Paper, No. 76, Cedefop, http://dx.doi.org/10.2801/62708.

Cedefop (2019), "The changing nature and role of vocational education and training in Europe. Volume 6: vocationally oriented education and training at higher education level. Expansion and diversification in European countries", Cedefop research paper, No. 70, http://dx.doi.org/10.2801/02004.

Cedefop (2017), Cedefop opinion survey on vocational education and training in Europe.

Cedefop (2017), Skills Panorama - Skills anticipation in Denmark, https://skillspanorama.cedefop.europa.eu/en/analytical highlights/skills-anticipation-denmark (accessed on 8 November 2019).

Cedefop (2013), "Labour market outcomes of vocational education in Europe: Evidence from the European Union labour force survey", Research paper, No. 32, Cedefop, https://www.cedefop.europa.eu/files/5532_en.pdf (accessed on 24 September 2019).

Cedefop and Eurofound (2018), "Skills forecast: trends and challenges to 2030", Cedefop reference series, No. 108, Cedefop, http://dx.doi.org/10.2801/4492.

Confédération Suisse (2019), La formation professionnelle en Suisse: Faits et chiffres 2019.

Confédération Suisse (2006), Ordonnance du SEFRI concernant les conditions minimales relatives à la culture générale dans la formation professionnelle initiale (412.101.241), https://www.admin.ch/opc/fr/classified-compilation/20061526/index.html (accessed on 8 November 2019).

De Kok, J. et al. (2011), Do SMEs create more and better jobs?, EIM Business \& Policy Research, Zoetermeer, http://www.eim.nl (accessed on 14 August 2019).

Dornmayr, H. and S. Nowak (2018), “Lehrlingsausbildung im Überblick 2018”, IBW Forschungsbericht, No. 193, IBW.

Edin, P. and M. Gustavsson (2008), “Time Out of Work and Skill Depreciation", ILR Review, Vol. 61/2, pp. 163-180, http://dx.doi.org/10.1177/001979390806100202.

Eurofound (2019), European Jobs Monitor - EMCC, https://www.eurofound.europa.eu/observatories/emcc/european-jobs-monitor (accessed on 4 November 2019).

Eurofound (2017), 6th European Working Conditions Survey - Overview Report (2017 Update), Publications Office of the European Union, Luxembourg, http://dx.doi.org/10.2806/784968. Office of the European Union, Luxembourg, http://dx.doi.org/10.2806/989106. 
Eurostat (2018), Glossary: Persons living in households with low work intensity, Statistics Explained, https://ec.europa.eu/eurostat/statisticsexplained/index.php/Glossary:Persons living in households with low work intensity (accessed on 13 August 2019).

Eurostat (2016), EU Labour Force Survey Explanatory Notes (To be applied from 2016Q1 onwards), https://ec.europa.eu/eurostat/documents/1978984/6037342/EU-LFS-explanatory-notes-from-2016onwards.pdf (accessed on 19 August 2019).

Eurostat (2013), EU Labour Force Survey Explanatory Notes (To be applied from 2014Q1 onwards), https://ec.europa.eu/eurostat/documents/1978984/6037342/EU-LFS-explanatory-notes-from-2014onwards.pdf (accessed on 19 August 2019).

Eurostat (n.d.), European Union Labour Force Survey (EU LFS), https://ec.europa.eu/eurostat/web/microdata/european-union-labour-force-survey (accessed on 20 August 2019).

Fernandez, R. et al. (2016), "Faces of Joblessness: Characterising Employment Barriers to Inform Policy", OECD Social, Employment and Migration Working Papers, No. 192, OECD, Paris, https://www.oecdilibrary.org/social-issues-migration-health/faces-of-joblessness_5jlwvz47xptj-en?crawler=true (accessed on 7 August 2019).

Field, S. and A. Guez (2018), Pathways of progression: Linking technical and vocational education and training with post-secondary education, UNESCO, Paris, http://www.unesco.org/ (accessed on 12 November 2019).

Forster, A., T. Bol and H. van de Werfhorst (2016), "Vocational Education and Employment over the Life Cycle”, Sociological Science, Vol. 3, pp. 473-494, http://dx.doi.org/10.15195/v3.a21.

Fouarge, D., A. Künn and D. Punt (2017), "De rol van arbeidsmarktinformatie in de opleidingskeuze van mbo'ers", ROA Reports, No. 009, Research Centre for Education and the Labour Market, Maastricht, http://www.roa.nl (accessed on 18 December 2019).

Frey, C. and M. Osborne (2017), “The future of employment: How susceptible are jobs to computerisation?", Technological Forecasting and Social Change, Vol. 114, pp. 254-280, http://dx.doi.org/10.1016/J.TECHFORE.2016.08.019.

Goos, M. and A. Manning (2007), "Lousy and Lovely Jobs: The Rising Polarization of Work in Britain", Review of Economics and Statistics, Vol. 89/1, pp. 118-133, http://dx.doi.org/10.1162/rest.89.1.118.

Goos, M., A. Manning and A. Salomons (2014), "Explaining Job Polarization: Routine-Biased Technological Change and Offshoring”, American Economic Review, Vol. 104/8, pp. 2509-2526, http://dx.doi.org/10.1257/aer.104.8.2509.

Green, A. (2019), "What is happening to middle skill workers?”, OECD Social, Employment and Migration Working Papers, No. 230, OECD Publishing, Paris, https://dx.doi.org/10.1787/a934f8fa-en.

Hall, C. (2016), "Does more general education reduce the risk of future unemployment? Evidence from an expansion of vocational upper secondary education", Economics of Education Review, Vol. 52, pp. 251-271, http://dx.doi.org/10.1016/j.econedurev.2016.03.005.

Hall, C. (2012), "The effects of reducing tracking in upper secondary school: Evidence from a large-scale pilot scheme", Journal of Human Resources, Vol. 47/1, pp. 237-269, http://dx.doi.org/10.3368/jhr.47.1.237. 
Hanushek, E. et al. (2017), "General Education, Vocational Education, and Labor-Market Outcomes over the Lifecycle", Journal of Human Resources, Vol. 52/1, pp. 48-87, http://dx.doi.org/10.3368/jhr.52.1.0415-7074R.

Heald, S., A. Smith and D. Fouarge (2019), Labour market forecasting scenario's for automation risks: Approach and outcomes, https://technequality-project.eu/files/d14fdmethodologyscenariodesignv10pdf (accessed on 21 February 2020).

Henriques, R. et al. (2018), "Vocational education: coursetaking choice and impact on dropout and college enrollment rates", Investigaciones de Economía de la Educación, Vol. 11.

Hoeckel, K. and R. Schwartz (2010), OECD Reviews of Vocational Education and Training: A Learning for Jobs Review of Germany 2010, OECD Reviews of Vocational Education and Training, OECD Publishing, Paris, https://dx.doi.org/10.1787/9789264113800-en.

ICT Formation professionnelle (2017), Cap sur l'avenir numérique - Stratégie 2022.

ILO (2018), Digital labour platforms and the future of work: Towards decent work in the online world, International Labour Office, Geneva, https://www.ilo.org/wcmsp5/groups/public/---dgreports/--dcomm/---publ/documents/publication/wcms 645337.pdf (accessed on 14 August 2019).

Kampelmann, S. and F. Rycx (2012), “The impact of educational mismatch on firm productivity: Evidence from linked panel data", Economics of Education Review, Vol. 31/6, pp. 918-931, http://dx.doi.org/10.1016/J.ECONEDUREV.2012.07.003.

Kís, V. (forthcoming), Improving evidence on VET: Data and Indicators.

Knight, B. and T. Karmel (2011), “Apprenticeships and traineeships in Australia”, in Dolphin, T. and T. Lanning (eds.), Rethinking Apprenticeships, IPPR, London, http://www.ippr.org (accessed on 8 November 2019).

KOF Swiss Economic Institute (2016), Feasibility Study for a Curriculum Comparison in Vocational Education and Training - Intermediary Report II: Education-Employment Linkage Index, http://dx.doi.org/10.3929/ethz-a-010696087.

Krahn, H. and G. Lowe (1998), Literacy Utilization in Canadian Workplaces - ARCHIVED, Statistics Canada, https://www150.statcan.gc.ca/n1/en/catalogue/89-552-M1998004 (accessed on 3 September 2019).

Kuczera, M. and S. Field (2018), Apprenticeship in England, United Kingdom, OECD Publishing, Paris, https://www.oecd-ilibrary.org/docserver/9789264298507en.pdf? expires $=1534168851 \& \mathrm{id}=\mathrm{id} \&$ acc name $=$ ocid $84004878 \&$ checksum $=3322 \mathrm{~F} 46082 \mathrm{~B} 5 \mathrm{C} 0237 \mathrm{D} 30$ C28C9B76E041 (accessed on 13 August 2018).

Kulik, J. (1998), "Curricular tracks and high school vocational education”, in Gamoran, A. (ed.), The quality of vocational education: Background papers from the 1994 National Assessment of Vocational Education, US Department of Education, Washington.

Lasonen, J. (2005), Workplaces as Learning Environments: Assessments by Young People after Transition from School to Work, http://www.bwpat.de/7eu (accessed on 19 August 2019).

MacDonald, D. (2019), "Bridging the ISCO break". 
MBO Raad (2019), Doorstroom mbo-hbo, https://www.mboraad.nl/themas/doorstroom-mbo-hbo (accessed on 12 November 2019).

Mcguinness, S. and J. Sloane (2011), "Labour market mismatch among UK graduates: An analysis using REFLEX data | Seamus McGuinness | Request PDF”, Economics of Education Review, Vol. 30/1, pp. 130-145, https://www.researchgate.net/publication/227360276_Labour_market_mismatch_among_UK_graduate s_An_analysis_using_REFLEX_data (accessed on 3 September 2019).

Ministère du Travail, de l'Emploi, de la Formation professionnelle et du Dialogue Social (2016), Le [100] Conseil en Évolution Professionnelle (CEP).

Ministry of Education (2008), The Danish Vocational Education and Training System. 2nd edition, http://static.uvm.dk/Publikationer/2008/VET2/kap02.html (accessed on 8 November 2019).

Musset, P. and L. Kureková (2018), "Working it out: Career guidance and employer engagement", OECD Education Working Papers Series, No. 175, OECD, Paris, http://www.oecd.org/edu/workingpapers (accessed on 3 August 2018).

Nedelkoska, L. and G. Quintini (2018), "Automation, skills use and training”, OECD Social, Employment and Migration Working Papers, No. 202, OECD Publishing, Paris, https://dx.doi.org/10.1787/2e2f4eea-en.

Norwegian Directorate for Education and Training (2018), Fag- og timefordeling og tilbudsstruktur for Kunnskapsløftet Udir-1-2018, https://www.udir.no/laring-og-trivsel/lareplanverket/fag-ogtimefordeling/Tidligere-rundskriv/udir-01-2018/ (accessed on 8 November 2019).

Norwegian Directorate for Education and Training (2013), VET in Europe: Country Report 2013 Norway, http://www.cedefop.europa.eu/EN/Informa- (accessed on 12 November 2019).

OECD (2019), Getting Skills Right: Creating Responsive Adult Learning Systems, OECD, http://www.oecd.org/els/emp/adult-learning-systems-2019.pdf (accessed on 17 September 2019).

OECD (2019), Getting Skills Right: Engaging Low-Skilled Adults in Learning, http://www.oecd.org/employment/emp/engaging-low-skilled-adults-2019.pdf (accessed on 9 October 2019).

OECD (2019), Getting Skills Right: Future-Ready Adult Learning Systems, Getting Skills Right, OECD Publishing, Paris, https://dx.doi.org/10.1787/9789264311756-en.

OECD (2019), Negotiating Our Way Up: Collective Bargaining in a Changing World of Work, OECD Publishing, Paris, https://dx.doi.org/10.1787/1fd2da34-en.

OECD (2019), OECD Employment Outlook 2019: The Future of Work, OECD Publishing, Paris, https://dx.doi.org/10.1787/9ee00155-en.

OECD (2019), OECD SME and Entrepreneurship Outlook 2019, OECD, Paris, https://doi.org/10.1787/34907e9c-en.

OECD (2018), Education at a Glance 2018: OECD Indicators, OECD Publishing, Paris, https://dx.doi.org/10.1787/eag-2018-en.

OECD (2018), Good Jobs for All in a Changing World of Work: The OECD Jobs Strategy, OECD Publishing, Paris, https://dx.doi.org/10.1787/9789264308817-en. 
OECD (2018), "Online work in OECD countries", Policy Brief on the Future of Work, OECD, Paris, http://www.oecd.org/employment/future-of-work.htm (accessed on 14 August 2019).

OECD (2018), Seven Questions about Apprenticeships: Answers from International Experience, OECD Reviews of Vocational Education and Training, OECD Publishing, Paris, https://dx.doi.org/10.1787/9789264306486-en.

OECD (2018), Skills for Jobs - 2018 Insights, OECD, Paris, http://www.oecdskillsforjobsdatabase.org (accessed on 14 August 2019).

OECD (2018), The Future of Social Protection: What Works for Non-standard Workers?, OECD Publishing, Paris, https://dx.doi.org/10.1787/9789264306943-en.

OECD (2017), Getting Skills Right: Skills for Jobs Indicators, Getting Skills Right, OECD Publishing, Paris, https://dx.doi.org/10.1787/9789264277878-en.

OECD (2017), "How technology and globalisation are transforming the labour market", in $O E C D$ Employment Outlook 2017, OECD Publishing, Paris, https://dx.doi.org/10.1787/empl_outlook-2017-7en.

OECD (2016), Getting Skills Right: Assessing and Anticipating Changing Skill Needs, Getting Skills Right, OECD Publishing, Paris, https://dx.doi.org/10.1787/9789264252073-en.

OECD (2016), Low-Performing Students: Why They Fall Behind and How To Help Them Succeed, PISA, OECD Publishing, Paris, https://dx.doi.org/10.1787/9789264250246-en.

OECD (2016), OECD Employment Outlook 2016, OECD Publishing, Paris, https://dx.doi.org/10.1787/empl outlook-2016-en.

OECD (2016), PISA 2015 Results (Volume II): Policies and Practices for Successful Schools, PISA, OECD Publishing, Paris, https://dx.doi.org/10.1787/9789264267510-en.

OECD (2016), Skills Matter: Further Results from the Survey of Adult Skills, OECD Skills Studies, OECD Publishing, Paris, https://dx.doi.org/10.1787/9789264258051-en.

OECD (2014), OECD Skills Strategy Diagnostic Report: Austria 2014, OECD Skills Studies, OECD Publishing, Paris, https://dx.doi.org/10.1787/9789264300255-en.

OECD (2010), Learning for Jobs, http://www.sourceoecd.org/9789264082236 (accessed on 8 November 2019).

OECD (2010), Off to a Good Start? Jobs for Youth, Jobs for Youth/Des emplois pour les jeunes, OECD Publishing, Paris, https://dx.doi.org/10.1787/9789264096127-en.

OECD (2006), Education at a Glance 2006: OECD Indicators, OECD Publishing, Paris, https://dx.doi.org/10.1787/eag-2006-en.

OECD (forthcoming), Increasing adult learning participation - learning from successful reforms, OECD Publishing.

OECD/European Commission (2004), Career Guidance: A Handbook for Policy Makers, OECD Publications, Paris, http://www.oecd.org/education/innovation-education/34060761.pdf (accessed on 8 October 2019). 
OECD/Eurostat/UNESCO Institute for Statistics (2015), ISCED 2011 Operational Manual: Guidelines for Classifying National Education Programmes and Related Qualifications, OECD Publishing, Paris, https://dx.doi.org/10.1787/9789264228368-en.

OECD/ILO (2017), Engaging Employers in Apprenticeship Opportunities: Making It Happen Locally, OECD Publishing, Paris, https://dx.doi.org/10.1787/9789264266681-en.

Pellizzari, M. and A. Fichen (2017), "A new measure of skill mismatch: theory and evidence from PIAAC”, IZA Journal of Labor Economics, Vol. 6/1, p. 1, http://dx.doi.org/10.1186/s40172-016-0051y.

Pesole, A. et al. (2018), Platform Workers in Europe, Publications Office of the European Union, Luxembourg, http://dx.doi.org/10.2760/742789.

Plank, S., S. DeLuca and A. Estacion (2005), Dropping Out of High School and the Place of Career and Technical Education: A Survival Analysis of Surviving High School, National Research Center for Career and Technical Education - University of Minnesota, Minnesota, http://www.nccte.com. (accessed on 13 November 2019).

Quintini, G. (2011), "Right for the Job: Over-Qualified or Under-Skilled?”, OECD Social, Employment and Migration Working Papers, No. 120, OECD Publishing, Paris, https://dx.doi.org/10.1787/5kg59fcz3tkd-en.

Rasmusson, M. et al. (2019), "Cognitive Foundation Skills Following Vocational Versus General UpperSecondary Education: A Long-Term Perspective", Scandinavian Journal of Educational Research, Vol. 63/7, pp. 985-1006, http://dx.doi.org/10.1080/00313831.2018.1466361.

Republic of Slovenia (2019), LLW - Slovenian Lifelong Learning Week 2019, https://llw.acs.si/about/ (accessed on 9 October 2019).

République Française (2019), Annexe au projet de loi de finance pour 2019 - Formation Professionnelle.

Robst, J. (1995), “CAREER MOBILITY, JOB MATCH, AND OVEREDUCATION”, Eastern Economic Journal, Vol. 21/4, pp. 539-550, https://about.jstor.org/terms (accessed on 3 September 2019).

Silliman, M. and H. Virtanen (2019), “Labor Market Returns to Vocational Secondary Education”, ETLA Working Papers, No. 65, https://www.etla.fi/en/publications/labor-market-returns-to-vocationalsecondary-education/ (accessed on 24 September 2019).

UnionLearn (2018), Union Learning Reps (ULRs), https://www.unionlearn.org.uk/union-learning-reps-ulrs (accessed on 9 October 2019).

Verhaest, D. et al. (2018), "General education, vocational education and skill mismatches: short-run versus long-run effects”, Oxford Economic Papers, Vol. 70/4, pp. 974-993, http://dx.doi.org/10.1093/oep/gpy026.

Windisch, H. (2015), “Adults with low literacy and numeracy skills: A literature review on policy intervention”, OECD Education Working Papers, No. 123, OECD Publishing, Paris, https://dx.doi.org/10.1787/5jrxnjdd3r5k-en.

Wolbers, M. (2003), "Job Mismatches and their Labour-Market Effects among School-Leavers in Europe”, European Sociological Review, Vol. 19/3, pp. 249-266, http://www.socsci.ru.nl/maartenw/esr03-3.pdf (accessed on 10 May 2019). 


\section{Annex A. VET definition in different datasets}

\section{EU-LFS}

The EU-LFS data contain information on the level of graduates' highest obtained qualification. Since 2014, education programmes at ISCED levels 3 and 4 are further broken down into vocational or general education programmes, based on the national ISCED mappings (Eurostat, 2016 ${ }_{[28]}$ ) and/or self-reporting by the individual (Eurostat, $\left.2013_{[29]}\right)$. This VET identifier is only available for individuals younger than 35 and for individuals older than 34 who completed their highest educational level at most 15 years before the date of the interview. The table below shows the share of graduates with a VET degree (in 2014-2017), based on the VET identifier.

Table A A.1. Share of VET graduates in EU-LFS data

$\%$ of graduates at ISCED levels 3 and 4 (2014-2017)

\begin{tabular}{rrrr}
\hline Country & VET share & Country & VET share \\
\hline Austria & $92 \%$ & Latvia & $46 \%$ \\
Belgium & $78 \%$ & Lithuania & $52 \%$ \\
Bulgaria & $53 \%$ & Malta & $11 \%$ \\
Croatia & $96 \%$ & Netherlands & $45 \%$ \\
Cyprus & $37 \%$ & Norway & $57 \%$ \\
Czech Republic & $95 \%$ & Poland & $77 \%$ \\
Denmark & $63 \%$ & Portugal & $52 \%$ \\
Estonia & $60 \%$ & Romania & $81 \%$ \\
Finland & $79 \%$ & Slovak Republic & $92 \%$ \\
France & $78 \%$ & Slovenia & $88 \%$ \\
Germany & $94 \%$ & Spain & $62 \%$ \\
Greece & $49 \%$ & Sweden & $65 \%$ \\
Hungary & $74 \%$ & Switzerland & $82 \%$ \\
Iceland & Ireland & United Kingdom & \\
Italy & $33 \%$ & $59 \%$
\end{tabular}

Note: Includes adults aged 15 to 34 not in education or training.

Source: Authors' calculations using EU-LFS (2014-2017).

Analyses for the years 2014-2017 are conducted using the VET indicator. In order to be able to conduct analyses on VET graduates prior to 2014, the VET indicator is used to classify each combination of education level and education field as either vocational or general (by country). For this purpose, all fields of study where, between 2014 and 2017, more than $50 \%$ of the graduates at a certain educational level indicate that their study programme was vocational, are classified as vocational programmes (see tables below). 
This classification is then used in the years prior to 2014, to label education fields and levels as either vocational or general.

Table A A.2. Share of VET by field of study (ISCED 300)

$\%$ of graduates at ISCED level 3 without possible distinction of access to other ISCED levels (2014-2017)

\begin{tabular}{|c|c|c|c|c|c|c|c|c|c|}
\hline \multirow[b]{2}{*}{ Country } & \multicolumn{9}{|c|}{ Field of study } \\
\hline & $\begin{array}{r}\text { Teacher } \\
\text { training and } \\
\text { education } \\
\text { science }\end{array}$ & $\begin{array}{r}\text { Humanities, } \\
\text { language } \\
\text { and arts }\end{array}$ & $\begin{array}{r}\text { Social } \\
\text { science, } \\
\text { business } \\
\text { and law }\end{array}$ & $\begin{array}{r}\text { Science, } \\
\text { mathematics } \\
\text { and } \\
\text { computing }\end{array}$ & $\begin{array}{r}\text { Computer } \\
\text { science }\end{array}$ & $\begin{array}{r}\text { Engineering, } \\
\text { manufacturing } \\
\text { and construction }\end{array}$ & $\begin{array}{r}\text { Agriculture } \\
\text { and } \\
\text { Veterinary }\end{array}$ & $\begin{array}{r}\text { Health } \\
\text { and } \\
\text { welfare }\end{array}$ & Services \\
\hline Greece & & & & & & $100 \%$ & & & $100 \%$ \\
\hline Sweden & & $80 \%$ & $81 \%$ & & $100 \%$ & $95 \%$ & $99 \%$ & $100 \%$ & $100 \%$ \\
\hline
\end{tabular}

Note: Includes adults aged 15 to 34 not in education or training.

Source: Authors' calculations using EU-LFS (2014-2017).

Table A A.3. Share of VET graduates by field of study (ISCED 304)

$\%$ of graduates at ISCED level 3 without access to tertiary education (2014-2017)

\begin{tabular}{|c|c|c|c|c|c|c|c|c|c|}
\hline & \multicolumn{9}{|c|}{ Field of study } \\
\hline Country & $\begin{array}{r}\text { Teacher } \\
\text { training } \\
\text { and } \\
\text { education } \\
\text { science }\end{array}$ & $\begin{array}{r}\text { Humanities, } \\
\text { language } \\
\text { and arts }\end{array}$ & $\begin{array}{r}\text { Social } \\
\text { science, } \\
\text { business } \\
\text { and law }\end{array}$ & $\begin{array}{r}\text { Science, } \\
\text { mathematics } \\
\text { and } \\
\text { computing }\end{array}$ & $\begin{array}{r}\text { Computer } \\
\text { science }\end{array}$ & $\begin{array}{r}\text { Engineering, } \\
\text { manufacturing } \\
\text { and } \\
\text { construction }\end{array}$ & $\begin{array}{r}\text { Agriculture } \\
\text { and } \\
\text { Veterinary }\end{array}$ & $\begin{array}{r}\text { Health } \\
\text { and } \\
\text { welfare }\end{array}$ & Services \\
\hline Belgium & & $100 \%$ & $100 \%$ & & & $100 \%$ & $100 \%$ & $100 \%$ & $100 \%$ \\
\hline Croatia & & $100 \%$ & $100 \%$ & & & $100 \%$ & $100 \%$ & & $100 \%$ \\
\hline $\begin{array}{l}\text { Czech } \\
\text { Republic }\end{array}$ & & $100 \%$ & $100 \%$ & & & $100 \%$ & $100 \%$ & $100 \%$ & $100 \%$ \\
\hline Denmark & & $100 \%$ & $100 \%$ & & $100 \%$ & $100 \%$ & $100 \%$ & $100 \%$ & $100 \%$ \\
\hline France & & $100 \%$ & $100 \%$ & & & $100 \%$ & $100 \%$ & $100 \%$ & $100 \%$ \\
\hline Germany & & & $100 \%$ & & & & & $100 \%$ & $100 \%$ \\
\hline Greece & & & $100 \%$ & & & $100 \%$ & & $100 \%$ & $100 \%$ \\
\hline Hungary & & $100 \%$ & $100 \%$ & & $100 \%$ & $100 \%$ & $100 \%$ & $100 \%$ & $100 \%$ \\
\hline Iceland & & & & & & $98 \%$ & & $92 \%$ & $95 \%$ \\
\hline Italy & & $100 \%$ & $100 \%$ & & $100 \%$ & $100 \%$ & $100 \%$ & $100 \%$ & $100 \%$ \\
\hline Latvia & & & & & & $100 \%$ & & & $100 \%$ \\
\hline Lithuania & & & & & & $100 \%$ & & & $100 \%$ \\
\hline Luxembourg & & & $0 \%$ & & & $21 \%$ & & $35 \%$ & $24 \%$ \\
\hline Malta & & $41 \%$ & $66 \%$ & & $76 \%$ & $79 \%$ & & $71 \%$ & $82 \%$ \\
\hline Netherlands & $100 \%$ & $100 \%$ & $100 \%$ & & $100 \%$ & $100 \%$ & $100 \%$ & $100 \%$ & $100 \%$ \\
\hline Norway & & $63 \%$ & $82 \%$ & & $75 \%$ & $78 \%$ & $62 \%$ & $77 \%$ & $67 \%$ \\
\hline Poland & & $100 \%$ & $100 \%$ & $100 \%$ & $100 \%$ & $100 \%$ & $100 \%$ & $100 \%$ & $100 \%$ \\
\hline Romania & $100 \%$ & $100 \%$ & $100 \%$ & $100 \%$ & $100 \%$ & $100 \%$ & $100 \%$ & & $100 \%$ \\
\hline $\begin{array}{l}\text { Slovak } \\
\text { Republic }\end{array}$ & & & $100 \%$ & & & $100 \%$ & $100 \%$ & & $100 \%$ \\
\hline Slovenia & & $100 \%$ & $100 \%$ & & & $100 \%$ & $100 \%$ & $100 \%$ & $100 \%$ \\
\hline Sweden & & $100 \%$ & $100 \%$ & & & $98 \%$ & $100 \%$ & $100 \%$ & $100 \%$ \\
\hline Switzerland & & & $100 \%$ & & & $100 \%$ & & & $100 \%$ \\
\hline $\begin{array}{l}\text { United } \\
\text { Kingdom }\end{array}$ & & $100 \%$ & $100 \%$ & & $100 \%$ & $100 \%$ & $100 \%$ & $100 \%$ & $100 \%$ \\
\hline
\end{tabular}

Note: Includes adults aged 15 to 34 not in education or training.

Source: Authors' calculations using EU-LFS (2014-2017). 
Table A A.4. Share of VET graduates by field of study (ISCED 305)

$\%$ of graduates at ISCED level 3 with access to tertiary education (2014-2017).

\begin{tabular}{|c|c|c|c|c|c|c|c|c|c|}
\hline \multirow[b]{2}{*}{ Country } & \multicolumn{9}{|c|}{ Field of study } \\
\hline & $\begin{array}{r}\text { Teacher } \\
\text { training } \\
\text { and } \\
\text { education } \\
\text { science }\end{array}$ & $\begin{array}{r}\text { Humanities, } \\
\text { language } \\
\text { and arts }\end{array}$ & $\begin{array}{r}\text { Social } \\
\text { science, } \\
\text { business } \\
\text { and law }\end{array}$ & $\begin{array}{r}\text { Science, } \\
\text { mathematics } \\
\text { and } \\
\text { computing }\end{array}$ & $\begin{array}{r}\text { Computer } \\
\text { science }\end{array}$ & $\begin{array}{r}\text { Engineering, } \\
\text { manufacturing } \\
\text { and } \\
\text { construction }\end{array}$ & $\begin{array}{r}\text { Agriculture } \\
\text { and } \\
\text { Veterinary }\end{array}$ & $\begin{array}{r}\text { Health } \\
\text { and } \\
\text { welfare }\end{array}$ & Services \\
\hline Austria & $100 \%$ & $100 \%$ & $100 \%$ & & $100 \%$ & $100 \%$ & $100 \%$ & $100 \%$ & $100 \%$ \\
\hline Belgium & $88 \%$ & $69 \%$ & $97 \%$ & $92 \%$ & $96 \%$ & $98 \%$ & $97 \%$ & $98 \%$ & $98 \%$ \\
\hline Bulgaria & & $100 \%$ & $100 \%$ & & & $100 \%$ & $100 \%$ & & $100 \%$ \\
\hline Croatia & & $100 \%$ & $100 \%$ & $100 \%$ & $100 \%$ & $100 \%$ & $100 \%$ & $100 \%$ & $100 \%$ \\
\hline Cyprus & & $35 \%$ & $4 \%$ & $0 \%$ & $46 \%$ & $98 \%$ & & & $97 \%$ \\
\hline $\begin{array}{l}\text { Czech } \\
\text { Republic }\end{array}$ & $100 \%$ & $100 \%$ & $100 \%$ & & $100 \%$ & $100 \%$ & $100 \%$ & $100 \%$ & $100 \%$ \\
\hline Denmark & & $0 \%$ & $0 \%$ & $0 \%$ & & $0 \%$ & & & \\
\hline Estonia & & $100 \%$ & $100 \%$ & & $100 \%$ & $100 \%$ & $100 \%$ & & $100 \%$ \\
\hline Finland & & $100 \%$ & $100 \%$ & & $100 \%$ & $100 \%$ & $100 \%$ & $100 \%$ & $100 \%$ \\
\hline France & & $20 \%$ & $50 \%$ & $0 \%$ & & $81 \%$ & $81 \%$ & $55 \%$ & $87 \%$ \\
\hline Germany & $100 \%$ & $100 \%$ & $100 \%$ & $100 \%$ & $100 \%$ & $100 \%$ & $100 \%$ & $100 \%$ & $100 \%$ \\
\hline Greece & $100 \%$ & $100 \%$ & $100 \%$ & & $100 \%$ & $100 \%$ & $100 \%$ & $100 \%$ & $100 \%$ \\
\hline Hungary & & $100 \%$ & $100 \%$ & & $100 \%$ & $100 \%$ & $100 \%$ & $100 \%$ & $100 \%$ \\
\hline \multicolumn{10}{|l|}{ Iceland } \\
\hline Italy & & $100 \%$ & $100 \%$ & & $100 \%$ & $99 \%$ & $100 \%$ & $100 \%$ & $100 \%$ \\
\hline Latvia & & $100 \%$ & $100 \%$ & & $100 \%$ & $100 \%$ & $100 \%$ & & $100 \%$ \\
\hline Lithuania & & $100 \%$ & $100 \%$ & & $100 \%$ & $100 \%$ & $100 \%$ & & $100 \%$ \\
\hline Luxembourg & $0 \%$ & $0 \%$ & $0 \%$ & & & $23 \%$ & & $31 \%$ & \\
\hline Malta & & $26 \%$ & $23 \%$ & $2 \%$ & $91 \%$ & & & & \\
\hline Netherlands & $100 \%$ & $100 \%$ & $100 \%$ & & $100 \%$ & $100 \%$ & $100 \%$ & $100 \%$ & $100 \%$ \\
\hline Norway & & $15 \%$ & $30 \%$ & & & & & & $2 \%$ \\
\hline Poland & & $98 \%$ & $100 \%$ & $100 \%$ & $100 \%$ & $100 \%$ & $100 \%$ & $100 \%$ & $100 \%$ \\
\hline Portugal & & $100 \%$ & $100 \%$ & & $100 \%$ & $100 \%$ & $100 \%$ & $100 \%$ & $100 \%$ \\
\hline Romania & $100 \%$ & $100 \%$ & $100 \%$ & $100 \%$ & $100 \%$ & $100 \%$ & $100 \%$ & $100 \%$ & $100 \%$ \\
\hline $\begin{array}{l}\text { Slovak } \\
\text { Republic }\end{array}$ & $100 \%$ & $100 \%$ & $100 \%$ & $100 \%$ & $100 \%$ & $100 \%$ & $100 \%$ & $100 \%$ & $100 \%$ \\
\hline Slovenia & $100 \%$ & $100 \%$ & $100 \%$ & & $100 \%$ & $100 \%$ & $100 \%$ & $100 \%$ & $100 \%$ \\
\hline Spain & $100 \%$ & $100 \%$ & $100 \%$ & $100 \%$ & $100 \%$ & $100 \%$ & $100 \%$ & $100 \%$ & $100 \%$ \\
\hline Sweden & & $87 \%$ & $75 \%$ & & $93 \%$ & $95 \%$ & $99 \%$ & $100 \%$ & $99 \%$ \\
\hline Switzerland & & $99 \%$ & $99 \%$ & & $99 \%$ & $100 \%$ & $100 \%$ & $99 \%$ & $100 \%$ \\
\hline $\begin{array}{l}\text { United } \\
\text { Kingdom }\end{array}$ & $100 \%$ & $100 \%$ & $99 \%$ & $100 \%$ & $100 \%$ & $100 \%$ & $99 \%$ & $100 \%$ & $56 \%$ \\
\hline
\end{tabular}

Note: Includes adults aged 15 to 34 not in education or training.

Source: Authors' calculations using EU-LFS (2014-2017). 
Table A A.5. Share of VET graduates by field of study (ISCED 400)

$\%$ of graduates at ISCED level 4 (2014-2017).

\begin{tabular}{|c|c|c|c|c|c|c|c|c|c|}
\hline & \multicolumn{9}{|c|}{ Field of study } \\
\hline Country & $\begin{array}{r}\text { Teacher } \\
\text { training and } \\
\text { education } \\
\text { science }\end{array}$ & $\begin{array}{r}\text { Humanities, } \\
\text { language } \\
\text { and arts }\end{array}$ & $\begin{array}{r}\text { Social } \\
\text { science, } \\
\text { business } \\
\text { and law }\end{array}$ & $\begin{array}{r}\text { Science, } \\
\text { mathematics } \\
\text { and } \\
\text { computing }\end{array}$ & $\begin{array}{r}\text { Computer } \\
\text { science }\end{array}$ & $\begin{array}{r}\text { Engineering, } \\
\text { manufacturing } \\
\text { and } \\
\text { construction }\end{array}$ & $\begin{array}{r}\text { Agriculture } \\
\text { and } \\
\text { Veterinary }\end{array}$ & $\begin{array}{r}\text { Health } \\
\text { and } \\
\text { welfare }\end{array}$ & Services \\
\hline Austria & & $100 \%$ & $100 \%$ & & & $100 \%$ & & $100 \%$ & $100 \%$ \\
\hline Belgium & & $100 \%$ & $100 \%$ & & & $100 \%$ & & $100 \%$ & $100 \%$ \\
\hline Cyprus & & & $100 \%$ & & & $100 \%$ & & & $100 \%$ \\
\hline Estonia & & & $100 \%$ & & $100 \%$ & $100 \%$ & $100 \%$ & $100 \%$ & $100 \%$ \\
\hline Germany & $100 \%$ & $100 \%$ & $100 \%$ & $100 \%$ & $100 \%$ & $100 \%$ & $100 \%$ & $100 \%$ & $100 \%$ \\
\hline Greece & $96 \%$ & $99 \%$ & $90 \%$ & $100 \%$ & $98 \%$ & $99 \%$ & $100 \%$ & $99 \%$ & $100 \%$ \\
\hline Hungary & $100 \%$ & $100 \%$ & $100 \%$ & $100 \%$ & $100 \%$ & $100 \%$ & $100 \%$ & $100 \%$ & $100 \%$ \\
\hline Iceland & & & & & & $100 \%$ & & & $100 \%$ \\
\hline Ireland & $100 \%$ & $100 \%$ & $100 \%$ & $100 \%$ & $100 \%$ & $100 \%$ & $100 \%$ & $100 \%$ & $100 \%$ \\
\hline Italy & $100 \%$ & $100 \%$ & $100 \%$ & $100 \%$ & $100 \%$ & $100 \%$ & & $100 \%$ & $100 \%$ \\
\hline Latvia & & $100 \%$ & $100 \%$ & & & $100 \%$ & & & $100 \%$ \\
\hline Lithuania & & $100 \%$ & $100 \%$ & & $100 \%$ & $100 \%$ & & & $100 \%$ \\
\hline Malta & $100 \%$ & $100 \%$ & $100 \%$ & & $100 \%$ & $100 \%$ & & $100 \%$ & $100 \%$ \\
\hline Poland & & $100 \%$ & $100 \%$ & & $100 \%$ & $100 \%$ & $100 \%$ & $100 \%$ & $100 \%$ \\
\hline Portugal & & $100 \%$ & $100 \%$ & & $100 \%$ & $100 \%$ & & $100 \%$ & $100 \%$ \\
\hline Romania & & & $100 \%$ & & & $100 \%$ & & $100 \%$ & $100 \%$ \\
\hline Slovak $\operatorname{Re}$ & ablic & & $100 \%$ & & & $100 \%$ & & $100 \%$ & $100 \%$ \\
\hline Sweden & $8 \%$ & $12 \%$ & $21 \%$ & $0 \%$ & $19 \%$ & $39 \%$ & $77 \%$ & $23 \%$ & $75 \%$ \\
\hline
\end{tabular}

Note: Includes adults aged 15 to 34 not in education or training.

Source: Authors' calculations using EU-LFS (2014-2017).

\section{EU-SILC}

In EU-SILC, the only relevant education variable refers to 'Highest ISCED level attained'. Since the 2014 wave of the survey, this variable follows the ISCED-2011 classification, having nine broad education level categories. ${ }^{45}$ Moreover, for people aged 16 to 34, ISCED levels 3 and 4 are further broken down in general and vocational education. In the years prior to 2014, only seven education levels were available, without a distinction between general and vocational. As the survey does not collect information on field-of-study, this means that it is not possible for the years prior to 2014 to determine whether a qualification was general or vocational. Therefore, the analyses using EU-SILC data are restricted to the years 2014-2017.

The distinction between general and vocational is not made in EU-SILC for Germany, so the analyses in the report using SILC data do not include Germany. Moreover, all of Ireland's qualifications at ISCED levels 3 and 4 are listed as general, and therefore the country is also excluded from the analyses. Finally, the vocational-general distinction is only available in 2014 for Italy, which means that the results presented for this country refer only to 2014 compared to 2014-2017 for all other countries. ${ }^{46}$

\footnotetext{
${ }^{45}$ In practice, the four tertiary levels are grouped in most countries.

46 As the vocational-general distinction is only available in 2014 for Italy, this country is not excluded in panel data analyses.
} 
Table A A.6. Share of VET graduates in EU-SILC data

$\%$ of graduates at ISCED levels 3 and 4 (2014-2017)

\begin{tabular}{rrrr}
\hline \multicolumn{1}{r}{ Country } & \multicolumn{1}{c}{ Share VET } & \multicolumn{2}{c}{ Share VET } \\
\hline Austria & $91.4 \%$ & Italy & $77.4 \%$ \\
Belgium & $76.4 \%$ & Lithuania & $56.6 \%$ \\
Bulgaria & $67.2 \%$ & Luxembourg & $83.2 \%$ \\
Switzerland & $80.4 \%$ & Latvia & $48.8 \%$ \\
Cyprus & $30.7 \%$ & Malta & $42.3 \%$ \\
Czech Republic & $92.0 \%$ & Netherlands & $79.6 \%$ \\
Denmark & $67.6 \%$ & Norway & $58.6 \%$ \\
Estonia & $30.6 \%$ & Poland & $76.2 \%$ \\
Greece & $52.2 \%$ & Portugal & $52.4 \%$ \\
Spain & $51.7 \%$ & Romania & $59.8 \%$ \\
Finland & $78.3 \%$ & Sweden & $64.4 \%$ \\
France & $76.5 \%$ & Slovenia & $88.8 \%$ \\
Croatia & $96.9 \%$ & Slovak Republic & $91.9 \%$ \\
Hungary & $90.2 \%$ & United Kingdom & $45.8 \%$ \\
Iceland & $42.7 \%$ & & \\
\hline
\end{tabular}

Note: Includes adults aged 16 to 34 who are not in education.

Source: Author's calculations using EU-SILC data.

\section{PIAAC}

In PIAAC, participants are asked about their highest obtained qualification. These qualifications are coded into the ISCED-97 classification. Moreover, a derived variable is available in PIAAC to indicate whether the highest obtained qualification was general or vocational. This variable is derived from the information regarding highest obtained qualification, supplemented by information provided by National Project Managers and OECD LSO network experts.

The distinction between general and vocational could not be made for all observations in PIAAC. To get an as large as possible sample, the information from the derived vocational variable is complemented with information from the EU-LFS on the share of vocational education graduates by education field and level. Whenever the derived variable is missing, but the field-level combination in LFS for that specific country has more than $90 \%$ vocational education graduates, the observation is labelled as 'vocational'. Conversely, when the field-level combination in LFS has less than $10 \%$ vocational education graduates, the observation is labelled as 'general'. Similarly, when a certain education level is always vocational in a certain country in the EU-LFS data, individuals with missing information for the derived variable in PIAAC who have that education level are labelled as vocational. A similar strategy is applied for fields that are purely vocational. Conversely, levels and fields that are entirely general in the EU-LFS are labelled as general in PIAAC if the derived variable is not available. This correction is only done for European countries, as similar information is not readily available for non-EU PIAAC countries. The final vocational indicator variable is missing for less than 10\% of ISCED 3-4 graduates in all countries except Sweden (14.3\%), Cyprus (22.6\%), Belgium (29.6\%) and the United States (35.1\%) (see Table A A.7).

As most of the analyses in this report focus on adults aged 16 to 34, some sample size issues emerge. This is particularly the case for the group of vocational education graduates in Spain, and general education graduates in Belgium, Italy, Slovenia and Turkey (plus 
Austria, Czech Republic and Germany to a lesser extent). Indicators based on less than 50 observations are not reported throughout the report.

Table A A.7. Share of VET graduates in PIAAC data

Share of VET graduates in PIAAC data

\begin{tabular}{|c|c|c|c|}
\hline & \multirow{2}{*}{$\begin{array}{c}\text { Share VET } \\
\text { (after correction) }\end{array}$} & \multicolumn{2}{|c|}{ Share missing } \\
\hline & & Raw & After LFS corrections \\
\hline Australia & $50.4 \%$ & $0.0 \%$ & $0.0 \%$ \\
\hline Austria & $92.7 \%$ & $0.0 \%$ & $0.0 \%$ \\
\hline Belgium & $90.9 \%$ & $65.1 \%$ & $29.6 \%$ \\
\hline Canada & $34.1 \%$ & $0.0 \%$ & $0.0 \%$ \\
\hline Chile & $50.7 \%$ & $0.0 \%$ & $0.0 \%$ \\
\hline Cyprus $^{12}$ & $34.6 \%$ & $100.0 \%$ & $22.6 \%$ \\
\hline Czech Republic & $95.2 \%$ & $0.0 \%$ & $0.0 \%$ \\
\hline Denmark & $65.0 \%$ & $14.1 \%$ & $7.3 \%$ \\
\hline Estonia & $59.8 \%$ & $0.0 \%$ & $0.0 \%$ \\
\hline Finland & $76.3 \%$ & $0.0 \%$ & $0.0 \%$ \\
\hline France & $76.4 \%$ & $0.0 \%$ & $0.0 \%$ \\
\hline Germany & $92.7 \%$ & $0.1 \%$ & $0.1 \%$ \\
\hline Greece & $63.0 \%$ & $0.0 \%$ & $0.0 \%$ \\
\hline Hungary & $83.3 \%$ & $33.8 \%$ & $0.3 \%$ \\
\hline Ireland & $47.8 \%$ & $0.0 \%$ & $0.0 \%$ \\
\hline Israel & $24.3 \%$ & $0.0 \%$ & $0.0 \%$ \\
\hline Italy & $92.2 \%$ & $81.3 \%$ & $0.1 \%$ \\
\hline Japan & $33.1 \%$ & $7.0 \%$ & $7.0 \%$ \\
\hline Korea & $52.9 \%$ & $0.0 \%$ & $0.0 \%$ \\
\hline Lithuania & $55.3 \%$ & $0.0 \%$ & $0.0 \%$ \\
\hline Mexico & $17.8 \%$ & $0.1 \%$ & $0.1 \%$ \\
\hline Netherlands & $80.2 \%$ & $0.0 \%$ & $0.0 \%$ \\
\hline New Zealand & $78.3 \%$ & $0.0 \%$ & $0.0 \%$ \\
\hline Norway & $63.8 \%$ & $0.0 \%$ & $0.0 \%$ \\
\hline Poland & $79.7 \%$ & $0.0 \%$ & $0.0 \%$ \\
\hline Slovak Republic & $35.0 \%$ & $0.0 \%$ & $0.0 \%$ \\
\hline Slovenia & $100.0 \%$ & $0.0 \%$ & $0.0 \%$ \\
\hline Spain & $16.2 \%$ & $0.0 \%$ & $0.0 \%$ \\
\hline Sweden & $65.6 \%$ & $27.9 \%$ & $14.3 \%$ \\
\hline Turkey & $100.0 \%$ & $0.0 \%$ & $0.0 \%$ \\
\hline United Kingdom & $43.6 \%$ & $49.8 \%$ & $3.9 \%$ \\
\hline United States & $25.1 \%$ & $35.1 \%$ & $35.1 \%$ \\
\hline
\end{tabular}

Note: Includes adults aged 16 to 34 who are not in education. Share vocational refers to the share of graduates who can be classified as either general or vocational (after the LFS correction), while the share of missings refers to all ISCED 3-4 graduates.

Source: Author's calculations using PIAAC data. 


\section{Annex B. Methodology details}

\section{Weights and averages}

All data presented in this report, including regression results, are calculated using the corresponding survey weights.

Cross-country averages are calculated in two ways:

- EU average: Represents the weighted average of the country results for all available EU-27 countries plus the United Kingdom.

- Average (or PIAAC average): Survey weights are used to calculate the country results, and these are aggregated by using a simple (unweighted) average across all available countries (i.e., including non-EU-27 countries). Country results based on less than 50 observations are not taken into account when calculating this average.

When time trends are presented for the average or EU average, the countries included in the trends are kept constant over time (i.e. maintaining a 'balanced panel'). This means that countries for which data are available only for a subset of years are excluded from the average in all years. This is necessary in order to exclude the possibility that changes in the time trend are merely due to changes in countries that are included in the sample. 


\section{Annex C. Additional figures and tables}

\section{Figure A C.1. Graduates and risk of automation, by occupation}

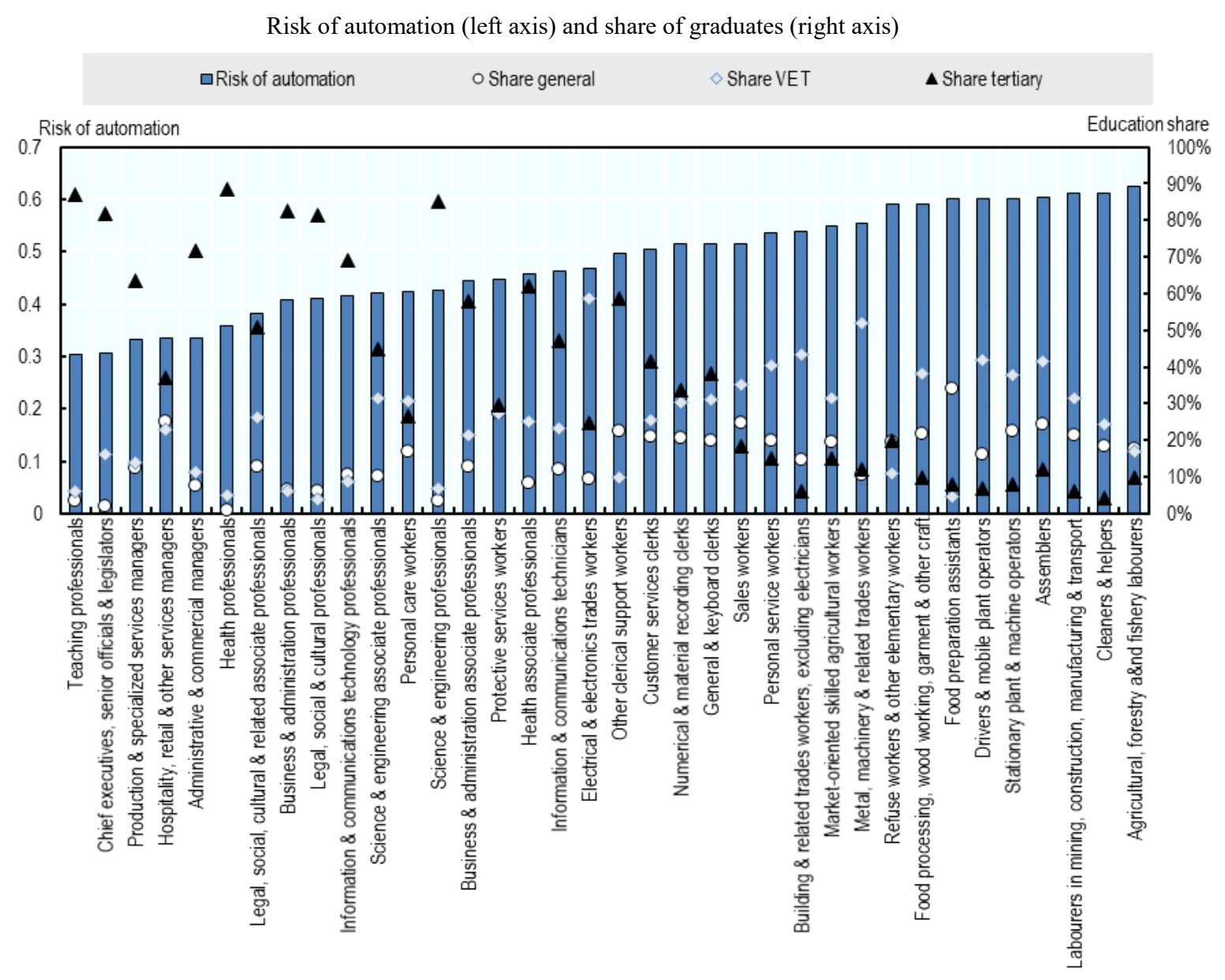

Note: Unweighted average across PIAAC countries. Risk of automation from Nedelkoska \& Quintini (2018 [12]).

Refers to individuals aged 16 to 34 not in education.

Source: Authors' calculations using the Survey of Adult Skills (2012, 2014, 2017). 


\section{Figure A C.2. Frequency of occupation changes - below upper secondary graduates}

Relative frequency of moving from one occupation to another (darker=more frequent)

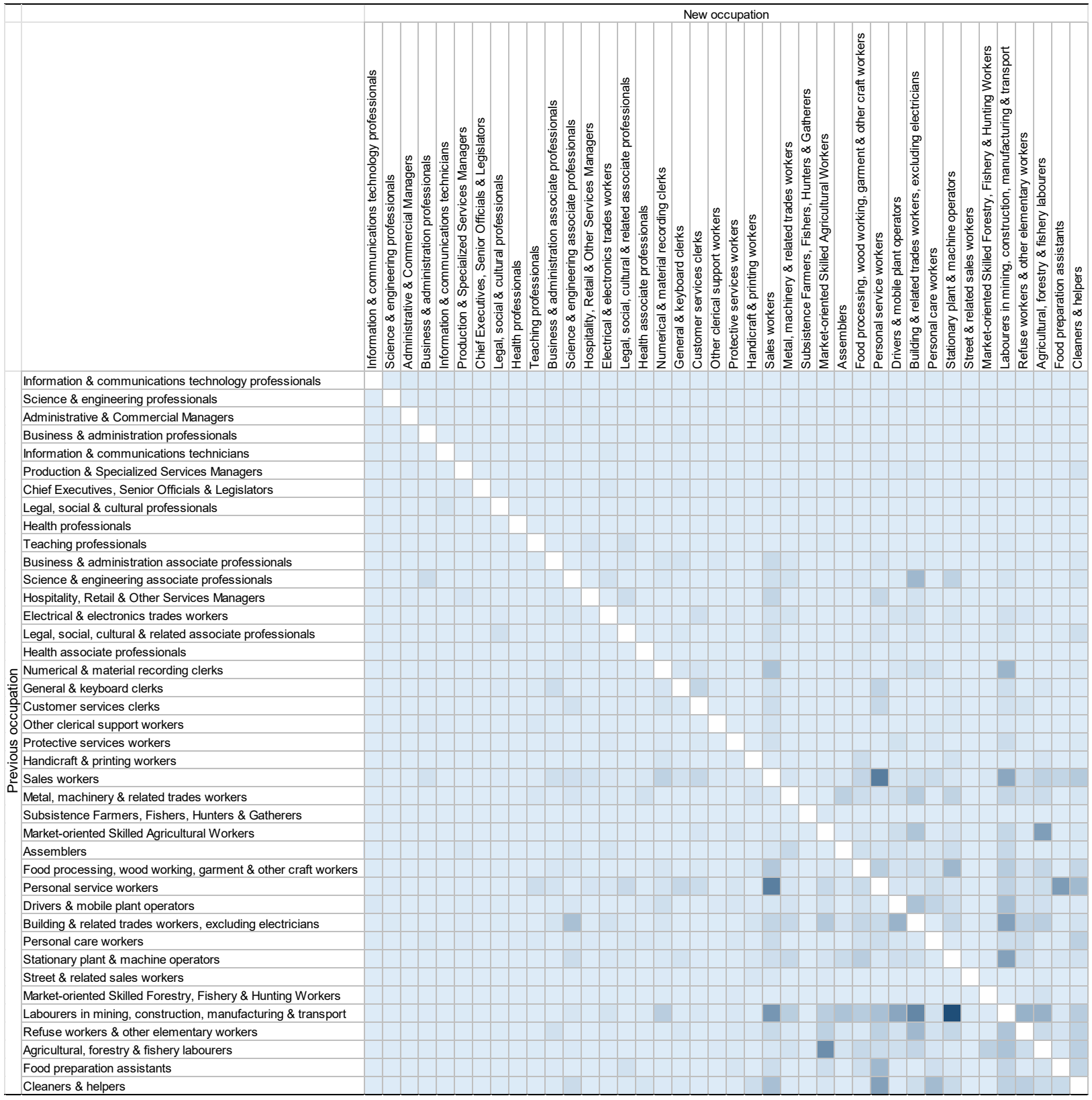

Note: Occupations are ranked in descending order by average numeracy proficiency. The lightest shade represents occupation combinations for which there were no recorded moves. Refers to moves made by individuals aged 15 to 34 not in education.

Source: Authors' calculations using EU-SILC data (2014-2017). 


\section{Figure A C.3. Frequency of occupation changes - general education graduates}

Relative frequency of moving from one occupation to another (darker=more frequent)

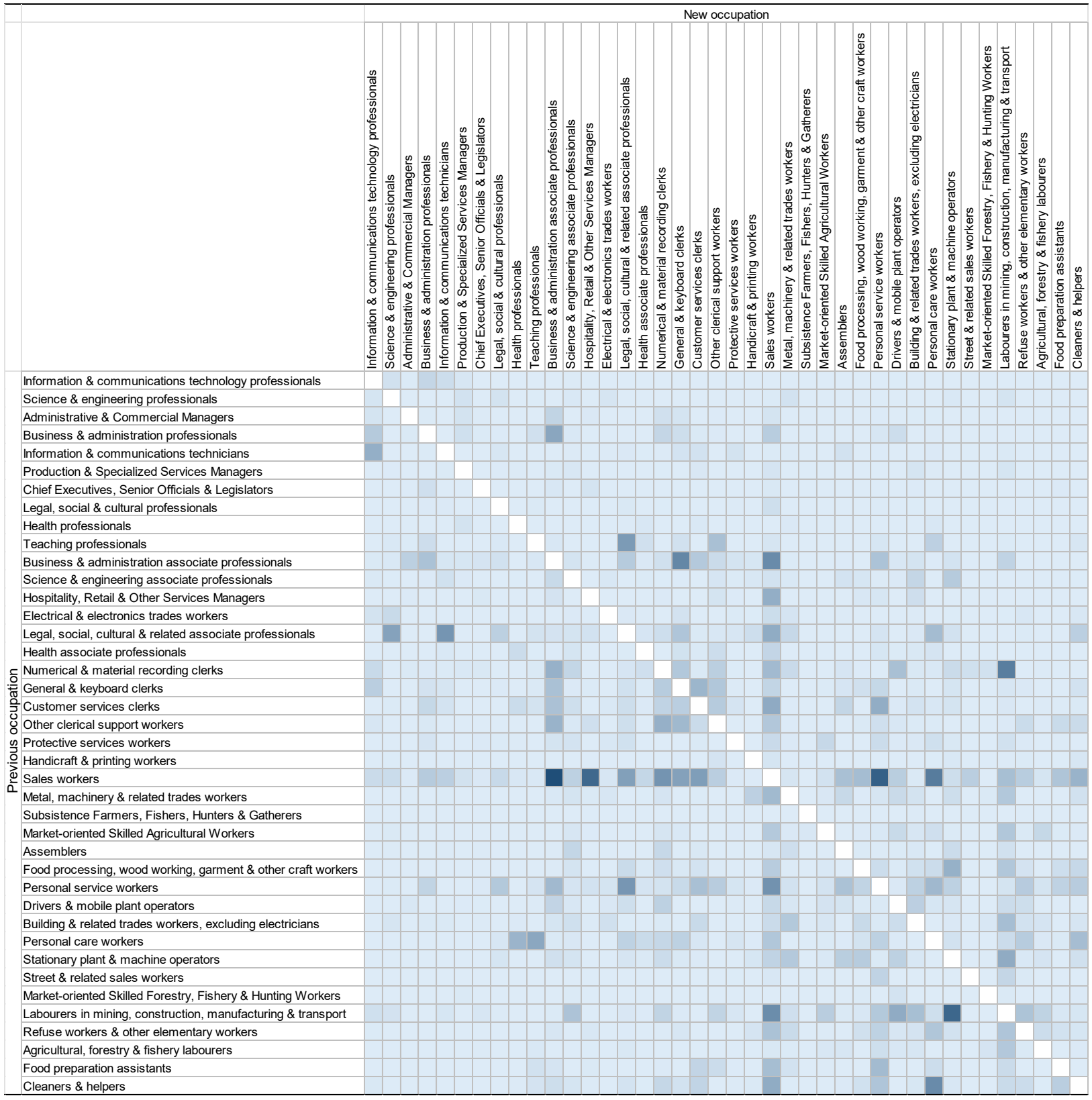

Note: Occupations are ranked in descending order by average numeracy proficiency. The lightest shade represents occupation combinations for which there were no recorded moves. Refers to moves made by individuals aged 15 to 34 not in education.

Source: Authors' calculations using EU-SILC data (2014-2017). 


\section{Figure A C.4. Frequency of occupation changes - vocational education graduates}

Relative frequency of moving from one occupation to another (darker=more frequent)

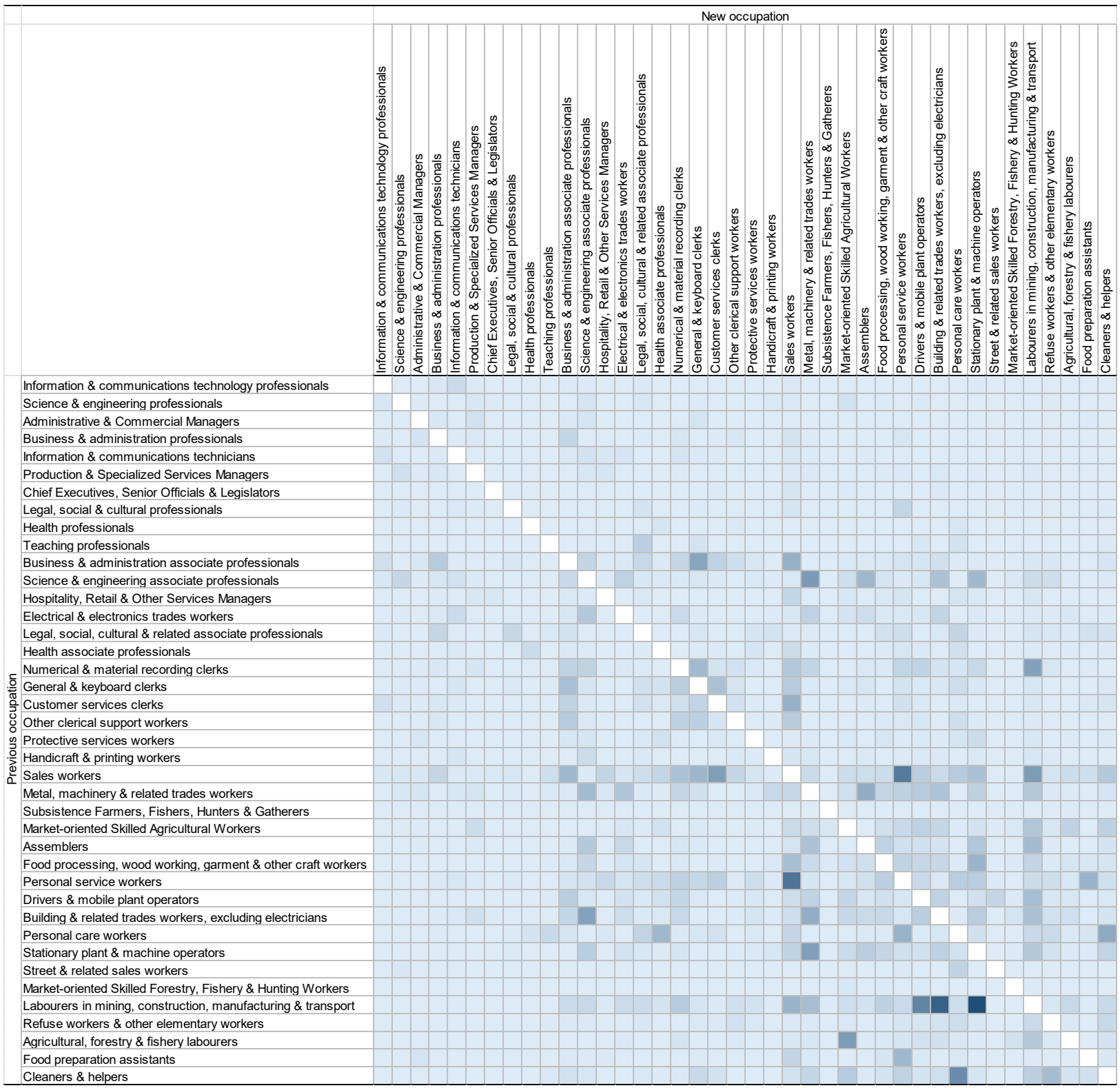

Note: Occupations are ranked in descending order by average numeracy proficiency. The lightest shade represents occupation combinations for which there were no recorded moves. Refers to moves made by individuals aged 15 to 34 not in education.

Source: Authors' calculations using EU-SILC data (2014-2017). 


\section{Figure A C.5. Frequency of occupation changes - tertiary education graduates}

Relative frequency of moving from one occupation to another (darker=more frequent)

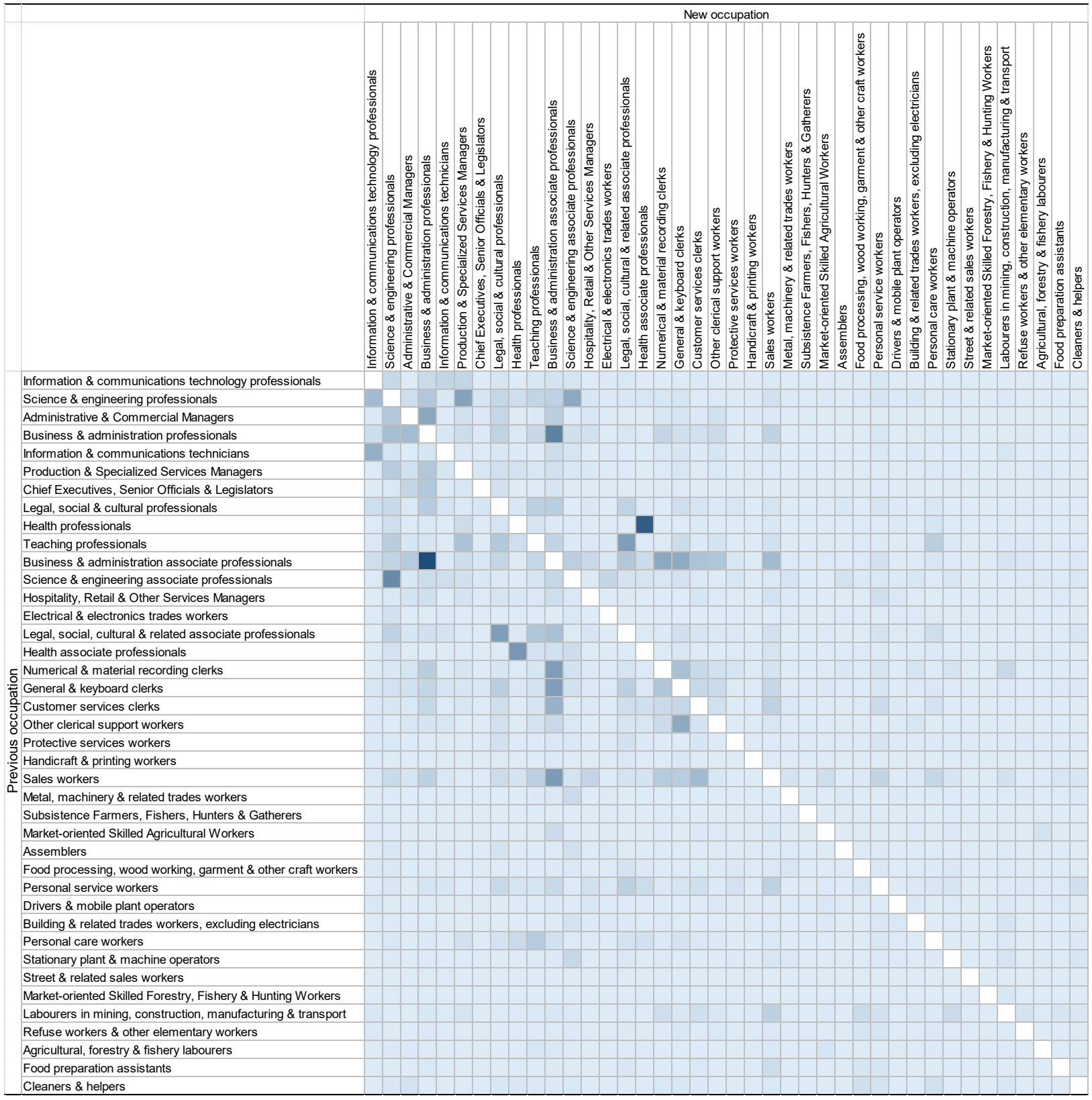

Note: Occupations are ranked in descending order by average numeracy proficiency. The lightest shade represents occupation combinations for which there were no recorded moves. Refers to moves made by individuals aged 15 to 34 not in education.

Source: Authors' calculations using EU-SILC data (2014-2017). 
Figure A C.6. Duration of unemployment spells

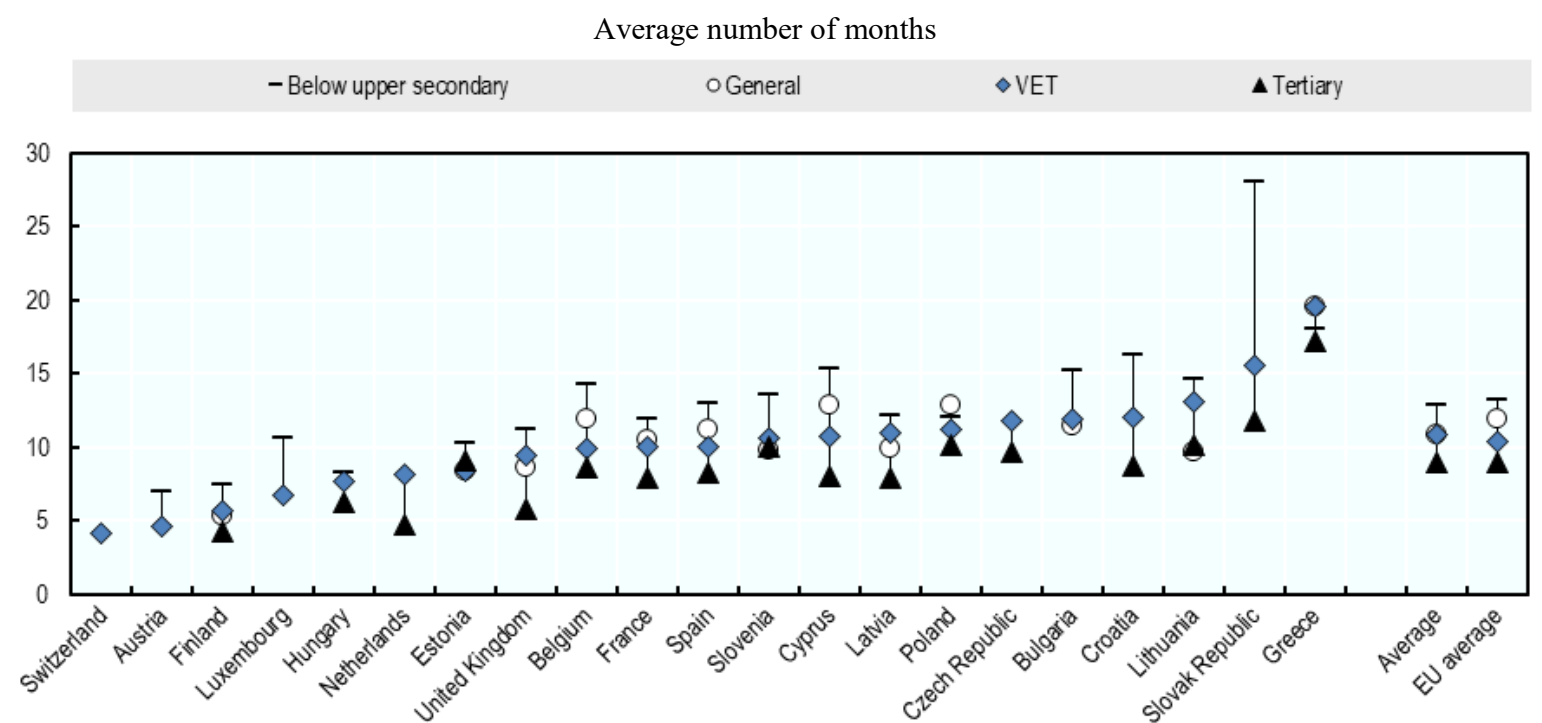

Note: All individuals aged 15 to 34 who are observed for four years are included. Years in which individuals spent six months or more in education are excluded. Unemployment spells that are shorter than half a month are not observed. Only countries with a sufficient number of observations are reported.

Source: Authors' calculations using EU-SILC data (2014-2017). 
Table A C.1. Most common occupations, by education

$\%$ of graduates of each education group

\begin{tabular}{|c|c|c|c|c|c|c|c|}
\hline \multicolumn{2}{|l|}{ Below upper-secondary } & \multicolumn{2}{|l|}{ General } & \multicolumn{2}{|l|}{ VET } & \multicolumn{2}{|l|}{ Tertiary } \\
\hline Shop Salespersons (522) & $8 \%$ & $\begin{array}{r}\text { Shop Salespersons } \\
(522)\end{array}$ & $12 \%$ & Shop Salespersons (522) & $9 \%$ & $\begin{array}{l}\text { Primary School and Early } \\
\text { Childhood Teachers (234) }\end{array}$ & $5 \%$ \\
\hline $\begin{array}{r}\text { Building Frame and } \\
\text { Related Trades Workers } \\
(711)\end{array}$ & $5 \%$ & $\begin{array}{r}\text { Waiters and Bartenders } \\
(513)\end{array}$ & $5 \%$ & $\begin{array}{l}\text { Personal Care Workers } \\
\text { in Health Services (532) }\end{array}$ & $4 \%$ & $\begin{array}{r}\text { Software and Applications } \\
\text { Developers and Analysts (251) }\end{array}$ & $4 \%$ \\
\hline $\begin{array}{r}\text { Domestic, Hotel and } \\
\text { Office Cleaners and } \\
\text { Helpers (911) }\end{array}$ & $5 \%$ & $\begin{array}{r}\text { General Office Clerks } \\
(411)\end{array}$ & $4 \%$ & $\begin{array}{r}\text { Machinery Mechanics } \\
\text { and Repairers (723) }\end{array}$ & $4 \%$ & $\begin{array}{r}\text { Engineering Professionals } \\
\text { (excluding Electrotechnology) } \\
(214)\end{array}$ & $4 \%$ \\
\hline $\begin{array}{r}\text { Transport and Storage } \\
\text { Labourers (933) }\end{array}$ & $4 \%$ & $\begin{array}{r}\text { Sales and Purchasing } \\
\text { Agents and Brokers } \\
(332)\end{array}$ & $4 \%$ & $\begin{array}{r}\text { Building Frame and } \\
\text { Related Trades Workers } \\
(711)\end{array}$ & $4 \%$ & Shop Salespersons (522) & $4 \%$ \\
\hline $\begin{array}{r}\text { Waiters and Bartenders } \\
\qquad(513)\end{array}$ & $3 \%$ & $\begin{array}{r}\text { Protective Services } \\
\text { Workers (541) }\end{array}$ & $3 \%$ & $\begin{array}{r}\text { Electrical Equipment } \\
\text { Installers and Repairers } \\
(741)\end{array}$ & $4 \%$ & Finance Professionals (241) & $3 \%$ \\
\hline $\begin{array}{r}\text { Mining and Construction } \\
\text { Labourers (931) }\end{array}$ & $3 \%$ & $\begin{array}{l}\text { Client Information } \\
\quad \text { Workers (422) }\end{array}$ & $3 \%$ & $\begin{array}{r}\text { Waiters and Bartenders } \\
(513)\end{array}$ & $3 \%$ & $\begin{array}{r}\text { Administration Professionals } \\
(242)\end{array}$ & $3 \%$ \\
\hline $\begin{array}{r}\text { Manufacturing Labourers } \\
(932)\end{array}$ & $3 \%$ & $\begin{array}{l}\text { Personal Care Workers } \\
\text { in Health Services (532) }\end{array}$ & $3 \%$ & $\begin{array}{r}\text { Hairdressers, } \\
\text { Beauticians and Related } \\
\text { Workers }(514)\end{array}$ & $3 \%$ & $\begin{array}{l}\text { Sales, Marketing and Public } \\
\text { Relations Professionals (243) }\end{array}$ & $3 \%$ \\
\hline $\begin{array}{l}\text { Agricultural, Forestry and } \\
\text { Fishery Labourers (921) }\end{array}$ & $3 \%$ & $\begin{array}{r}\text { Transport and Storage } \\
\text { Labourers (933) }\end{array}$ & $3 \%$ & $\begin{array}{r}\text { Building Finishers and } \\
\text { Related Trades Workers } \\
(712)\end{array}$ & $3 \%$ & $\begin{array}{l}\text { Social and Religious } \\
\text { Professionals (263) }\end{array}$ & $3 \%$ \\
\hline $\begin{array}{r}\text { Mobile Plant Operators } \\
(834)\end{array}$ & $3 \%$ & $\begin{array}{l}\text { Child Care Workers and } \\
\text { Teachers' Aides (531) }\end{array}$ & $3 \%$ & Cooks (512) & $2 \%$ & $\begin{array}{r}\text { Sales and Purchasing Agents } \\
\text { and Brokers (332) }\end{array}$ & $3 \%$ \\
\hline $\begin{array}{r}\text { Mixed Crop and Animal } \\
\text { Producers (613) }\end{array}$ & $3 \%$ & $\begin{array}{l}\text { Material recording and } \\
\text { Transport Clerks (432) }\end{array}$ & $2 \%$ & $\begin{array}{r}\text { Heavy Truck and Bus } \\
\text { Drivers (833) }\end{array}$ & $2 \%$ & $\begin{array}{l}\text { Financial and Mathematical } \\
\text { Associate Professionals (331) }\end{array}$ & $3 \%$ \\
\hline
\end{tabular}

Note: Includes employed individuals aged 15 to 34 not in education or training. Occupations that could not be identified at the 3 digit ISCO-08 level are excluded. ISCO-08 occupation codes in parenthesis.

Source: Authors' calculations using EU-LFS data (2017). 
Table A C.2. Occupations with the largest share of below upper-secondary, general, VET or tertiary education graduates

$\%$ of graduate employment within each occupation

\begin{tabular}{|c|c|c|c|c|c|c|c|}
\hline \multicolumn{2}{|l|}{ Below upper-secondary } & \multicolumn{2}{|l|}{ General } & \multicolumn{2}{|l|}{ VET } & \multicolumn{2}{|l|}{ Tertiary } \\
\hline $\begin{array}{r}\text { Fishery Workers, Hunters } \\
\text { and Trappers (622) }\end{array}$ & $81 \%$ & $\begin{array}{r}\text { Other Elementary } \\
\text { Workers (962) }\end{array}$ & $27 \%$ & $\begin{array}{r}\text { Veterinary Technicians and } \\
\text { Assistants (324) }\end{array}$ & $89 \%$ & $\begin{array}{r}\text { Librarians, Archivists and } \\
\text { Curators (262) }\end{array}$ & $99 \%$ \\
\hline $\begin{array}{r}\text { Street Vendors (excluding } \\
\text { Food) (952) }\end{array}$ & $75 \%$ & $\begin{array}{r}\text { Street and Market } \\
\text { Salespersons (521) }\end{array}$ & $26 \%$ & $\begin{array}{r}\text { Chemical and Photographic } \\
\text { Products Plant and } \\
\text { Machine Operators (813) }\end{array}$ & $79 \%$ & Medical Doctors (221) & $98 \%$ \\
\hline Refuse Workers (961) & $62 \%$ & $\begin{array}{r}\text { Ship and Aircraft } \\
\text { Controllers and } \\
\text { Technicians (315) }\end{array}$ & $25 \%$ & $\begin{array}{r}\text { Electrical Equipment } \\
\text { Installers and Repairers } \\
(741)\end{array}$ & $74 \%$ & Legal Professionals (261) & $98 \%$ \\
\hline $\begin{array}{c}\text { Agricultural, Forestry and } \\
\text { Fishery Labourers (921) }\end{array}$ & $52 \%$ & $\begin{array}{r}\text { Cashiers and Ticket } \\
\text { Clerks (523) }\end{array}$ & $25 \%$ & $\begin{array}{r}\text { Printing Trades Workers } \\
\text { (732) }\end{array}$ & $74 \%$ & $\begin{array}{l}\text { University and Higher } \\
\text { Education Teachers (231) }\end{array}$ & $97 \%$ \\
\hline $\begin{array}{r}\text { Vehicle, Window, Laundry } \\
\text { and Other Hand Cleaning } \\
\text { Workers (912) }\end{array}$ & $48 \%$ & $\begin{array}{r}\text { Waiters and } \\
\text { Bartenders (513) }\end{array}$ & $24 \%$ & $\begin{array}{r}\text { Blacksmiths, Toolmakers } \\
\text { and Related Trades } \\
\text { Workers (722) }\end{array}$ & $71 \%$ & $\begin{array}{r}\text { Engineering Professionals } \\
\text { (excluding } \\
\text { Electrotechnology) (214) }\end{array}$ & $96 \%$ \\
\hline $\begin{array}{r}\text { Mining and Construction } \\
\text { Labourers (931) }\end{array}$ & $42 \%$ & $\begin{array}{r}\text { Transport and } \\
\text { Storage Labourers } \\
\text { (933) }\end{array}$ & $24 \%$ & $\begin{array}{r}\text { Wood Processing and } \\
\text { Papermaking Plant } \\
\text { Operators (817) }\end{array}$ & $70 \%$ & $\begin{array}{r}\text { Secondary Education } \\
\text { Teachers (233) }\end{array}$ & $96 \%$ \\
\hline $\begin{array}{r}\text { Domestic, Hotel and } \\
\text { Office Cleaners and } \\
\text { Helpers (911) }\end{array}$ & $39 \%$ & $\begin{array}{r}\text { Sports and Fitness } \\
\text { Workers(342) }\end{array}$ & $23 \%$ & Handicraft Workers (731) & $69 \%$ & $\begin{array}{r}\text { Life Science Professionals } \\
\text { (213) }\end{array}$ & $95 \%$ \\
\hline $\begin{array}{r}\text { Food Preparation } \\
\text { Assistants (941) }\end{array}$ & $38 \%$ & $\begin{array}{r}\text { Food and Related } \\
\text { Products Machine } \\
\text { Operators (816) }\end{array}$ & $23 \%$ & Cooks (512) & $69 \%$ & $\begin{array}{r}\text { Mathematicians, Actuaries } \\
\text { and Statisticians (212) }\end{array}$ & $95 \%$ \\
\hline $\begin{array}{r}\text { Forestry and Related } \\
\text { Workers (621) }\end{array}$ & $35 \%$ & $\begin{array}{r}\text { Shop Salespersons } \\
(522)\end{array}$ & $23 \%$ & $\begin{array}{r}\text { Machinery Mechanics and } \\
\text { Repairers (723) }\end{array}$ & $68 \%$ & $\begin{array}{r}\text { Information and } \\
\text { Communications Technology } \\
\text { Services Managers (133) }\end{array}$ & $95 \%$ \\
\hline $\begin{array}{r}\text { Manufacturing Labourers } \\
\text { (932) }\end{array}$ & $34 \%$ & $\begin{array}{r}\text { Other Sales Workers } \\
(524)\end{array}$ & $23 \%$ & $\begin{array}{r}\text { Wood Treaters, Cabinet- } \\
\text { makers and Related Trades } \\
\text { Workers (752) }\end{array}$ & $68 \%$ & $\begin{array}{r}\text { Social and Religious } \\
\text { Professionals (263) }\end{array}$ & $94 \%$ \\
\hline
\end{tabular}

Note: Includes employed individuals aged 15 to 34 not in education or training. Occupations that could not be identified at the 3 digit ISCO-08 level are excluded. ISCO-08 occupation codes in parenthesis. Countries where less than 50 respondents have a certain 3-digit ISCO-08 occupation are excluded from the average. Source: Authors' calculations using EU-LFS data (2017) 